\title{
The Concept of the Sacred in Post-Soviet Literature
}

By

\author{
Akvilina Cicenaite
}

\begin{abstract}
A thesis
submitted to the Victoria University of Wellington in fulfilment of the requirements for the degree of Doctor of Philosophy in Religious Studies
\end{abstract}

Victoria University of Wellington

2013 


\section{Abstract}

Rejecting the prior essentialist assumptions connected with the classical notions of the sacred, this dissertation argues for the redefinition of this concept and its use as an analytical tool. Religion, too, should no longer be held as a privileged space for the emergence of the sacred. The sacred is held not to be a numinous phenomenon experienced privately, a universal term, or of an unchangeable structure. Instead, it is a relative and temporary category constructed through certain cultural practices, which helps us disclose the concepts of meaning, identity and community. Such a redefined notion can be applied when speaking about contemporary culture and literature.

This dissertation presents Russian writer Victor Pelevin as a case study, demonstrating the possibility to speak of the sacred in the seemingly secular post-Soviet milieu. It provides insights into the role of the sacred in his works and introduces new possible approaches towards his writings and his position in Russian literature. Moreover, the analysis of Pelevin's works shows that this redefined understanding of the sacred is productive not only in his writings, but also in general in the studies of sacrality in the postmodern world, making this post-Soviet sacred a more extensive concept, applicable in a wide variety of contexts. 


\section{Acknowledgements}

Victoria University of Wellington was my home for the past three years. I am deeply grateful for all the people I met here and for all the possibilities to learn I was gifted.

First, I wish to thank my two supervisors: Dr Arthur Buehler was my primary supervisor for the first years, and Professor Paul Morris took over this role during the final year. Professor Morris was an unending source of wisdom, humour, encouragement and inspiration; it has been a real privilege to work with him on this project. Dr Buehler helped me to approach writing in a more effective way and introduced me to the subtle nuances of academic work. Thank you both for putting up with me in the early stages of my writing.

Special thanks go to Aliki Kalliabetsos for her kindness, support and understanding. Thank you for teaching me how to be strong in tough times.

I would also like to thank my colleagues from the Religious Studies programme for their encouragement and friendship: Kevin Connors, Eda Czarnecki, Alan Edwards, Lisa Eyre, Dr William Hoverd, Atsushi Iseki, Dr Negar Partow, Katja Strehle, and Michael Teitelbaum. You made this journey easier.

Many thanks to my dear friends in New Zealand, Lithuania, and to those scattered all around the world, who taught me that the time one enjoys wasting is not wasted time.

I wish to specially thank the two most beautiful women on earth, Virgina Ciceniene and Vanda Sodaitiene. My Mother and Sister, and all my family taught me what the notion of 'absolute love' really means.

Finally, I am immensely grateful to Patrick Charles for his endless patience, support and love, and for the wisdom from the German aerospace engineer Max Munk, who pioneered aircraft wing theory. "The 'emptiness' above a wing makes a plane fly, which leads to infinite [destination] possibilities."

My research was assisted by a Victoria University of Wellington Postgraduate Scholarship for PhD study. 


\section{Table of Contents}

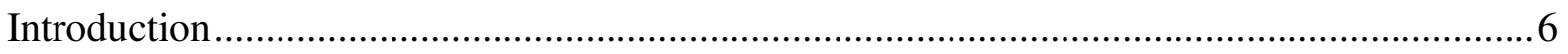

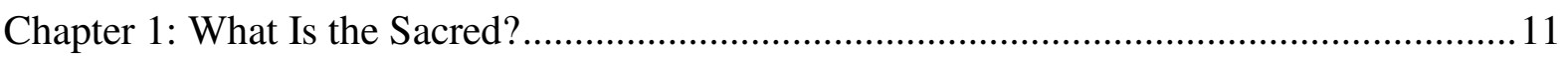

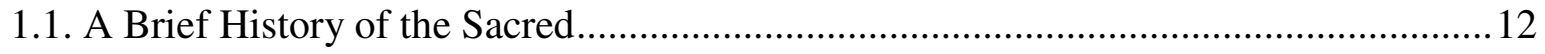

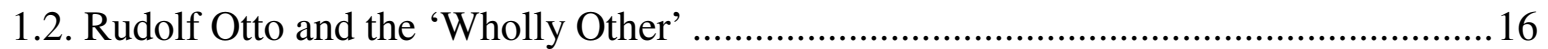

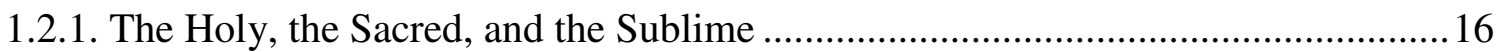

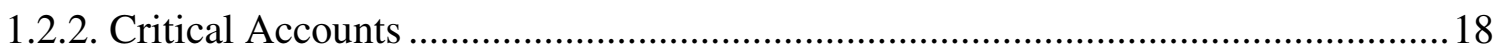

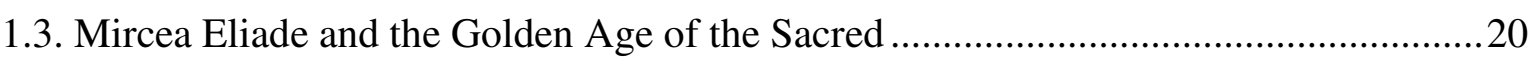

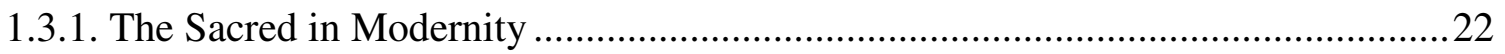

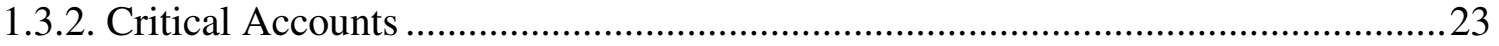

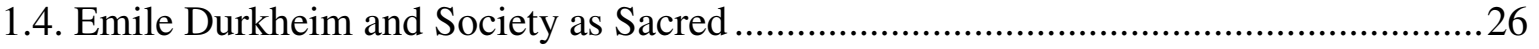

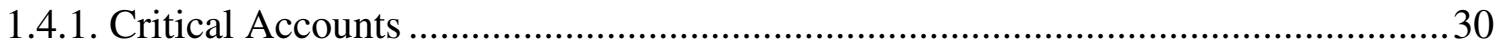

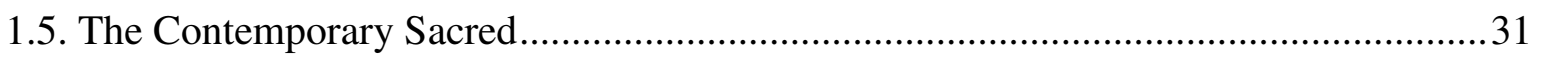

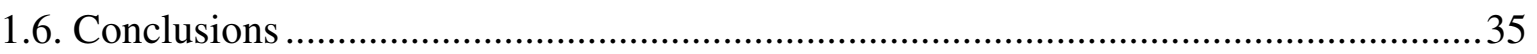

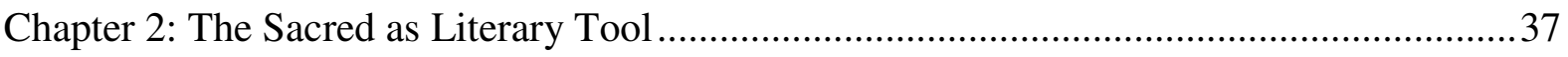

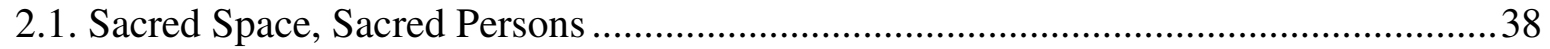

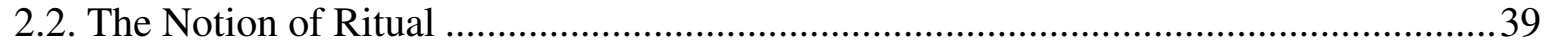

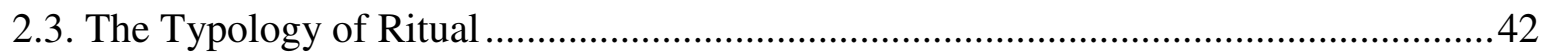

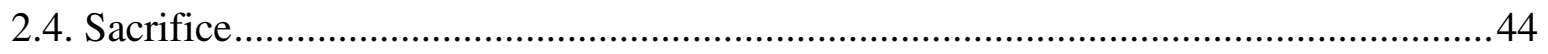

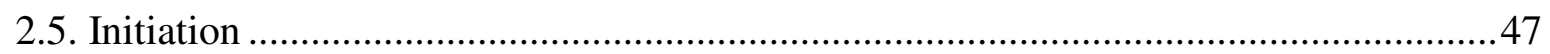

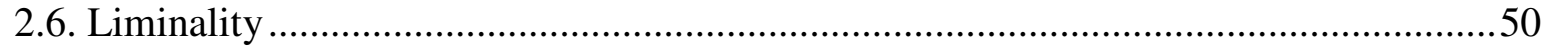

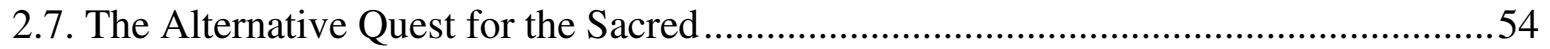

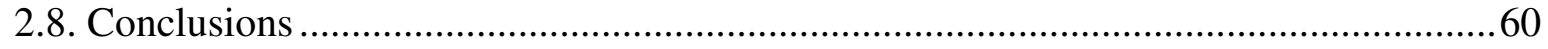

Chapter 3: The Post-Soviet Condition: Reinventing the Sacred.............................................61

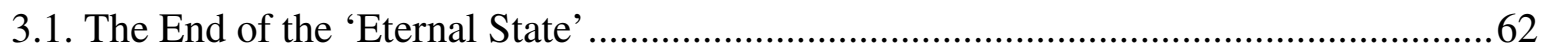

3.2. Religion Between Soviet and Post-Soviet Worlds ................................................ 65

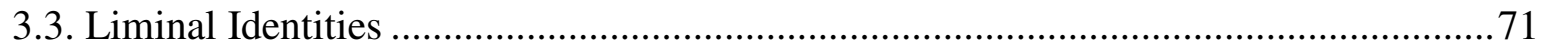

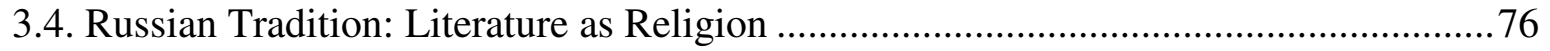

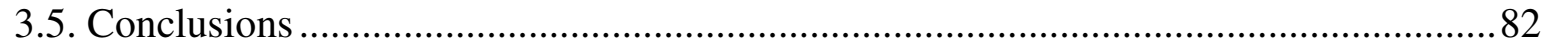

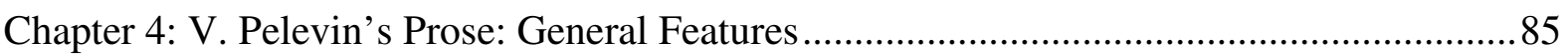

4.1. Victor Pelevin: From the Eternal State to the Eternal Non-Return ................................. 85

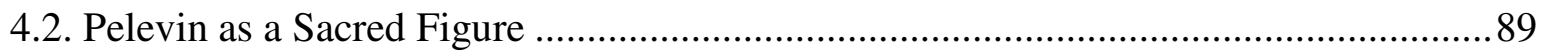




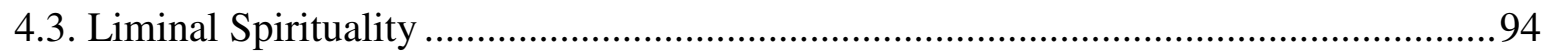

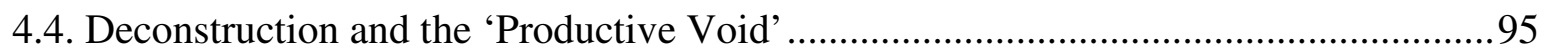

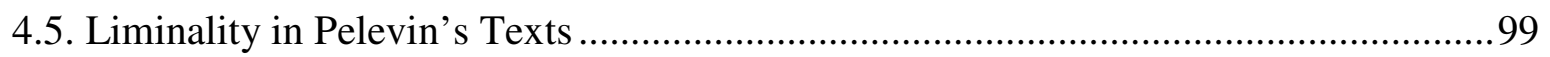

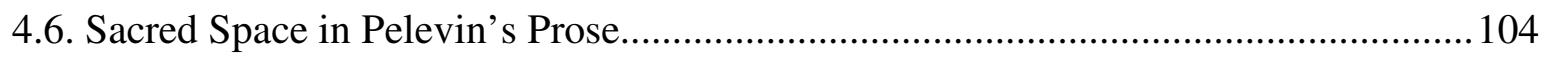

4.7. Sacred Persons in Pelevin's Prose ............................................................................110

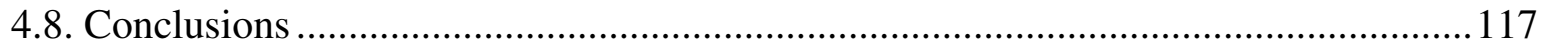

Chapter 5: Initiation and Sacrifice in V. Pelevin's Prose ……………………………........119

5.1. The Making of a Soviet Man...................................................................................... 120

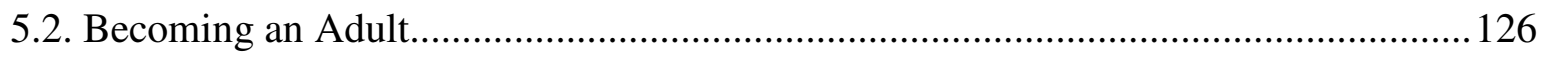

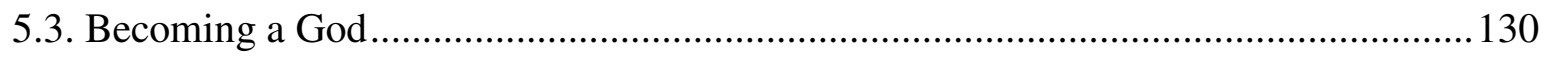

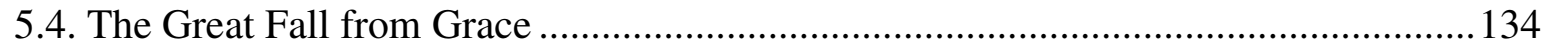

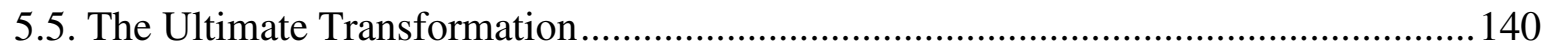

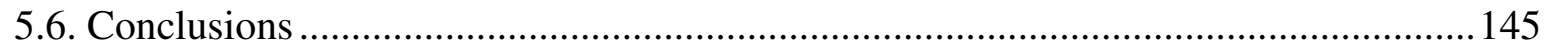

Chapter 6: The Sacred as Escape in V. Pelevin's Prose …………………………….............148

6.1. The Sacred Trip to Babylon ...............................................................................150

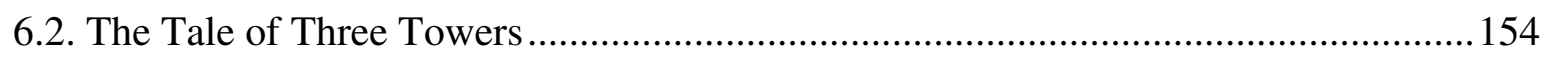

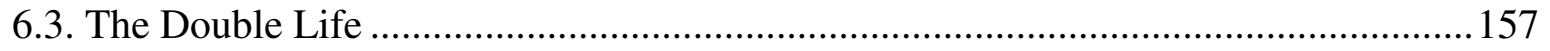

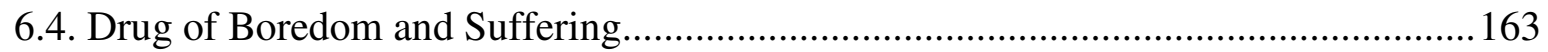

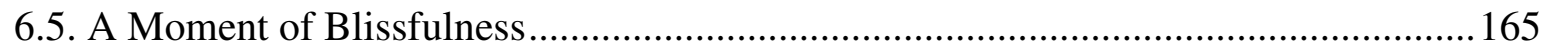

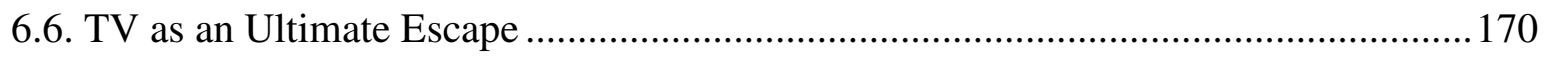

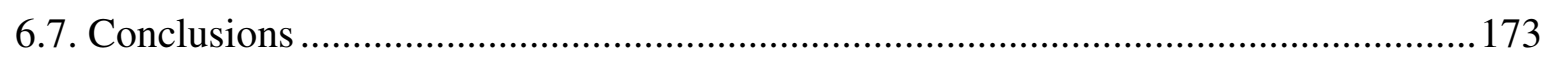

Chapter 7: The Sacred Journey to 'Freedom' ...................................................................176

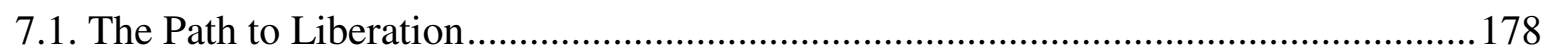

7.2. Emptiness as Absolute Freedom .......................................................................... 184

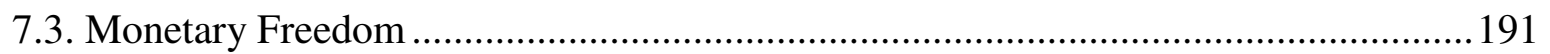

7.4. Optina Pustyn as the Ultimate Destination ................................................................ 194

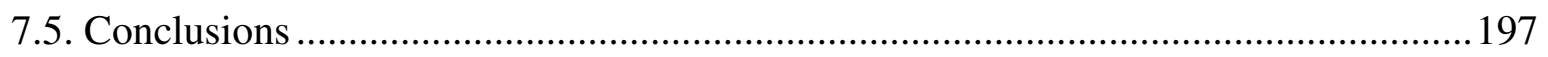

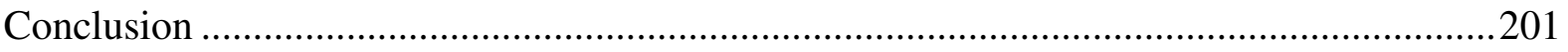

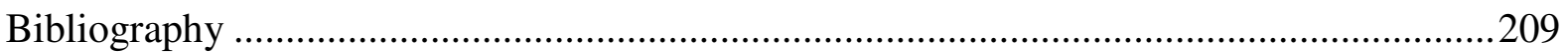




\section{Introduction}

"If you're seriously dedicated to anything, be it art, science, or whatever, that which you are dedicated to is going to be a pretty big component in what is sacred to you.",

When the Soviet Union fell apart, I was still too young to don the red pioneer scarf as my sister had done. Instead, I joined the newly reconstituted scouts, the organisation which in Lithuania was very Catholic. Ironically, the head of this organisation was the former leader of the pioneers, a formerly devout Communist and no doubt a former atheist. This was probably the first time when as a child I started pondering the temporality and relativity of certain belief systems.

After the euphoria of the 'singing revolution' that eventually led to the restoration of the independence of Lithuania, the Soviet Union, still clinging to life, lashed out and my country, like many of the other former Soviet countries, suffered. Yet, we faced those years of shortages and economic transition, jealously watching the newly-adapted TV ads, waiting for the blessed Western world to impact the grey and depressing streets of our sad cities, and dreaming that one day the 'distant forbidden world on the far side of the sea' would become part of our lives.

I received my university education and began a promising career in advertising, living the ideal Western dream. The coveted world was here, but for a significant part of my generation, the moment of bliss proved fleeting. We searched for more and tried to find our satisfactory niche. Some of us became acquainted with popular New Age beliefs and new spiritualities, others travelled to India and beyond, some re-discovered Christianity, some pursued their careers and found happiness in spending money in the newly opened gigantic shopping malls, some chose sanctuary through drugs and alcohol. This freedom of choice also included freedom of movement; large numbers fled Lithuania in search of greener pastures.

Yet it seemed that however painful the lack of choice appeared to be during the 70 years of Soviet occupation, the plethora of choices following independence proved equally unsatisfactory. This eventually made me raise the question of whether there can be anything that would give this generation meaning and define it, in other words, whether there can be anything sacred for the generation which supposedly had 'nothing sacred' left.

\footnotetext{
${ }^{1}$ Kay Milton, Loving Nature: Towards an Ecology of Emotion (London: Routledge, 2002), 104.
} 
This question brought me to the Religious Studies programme at Victoria University of Wellington and encouraged me to write a dissertation on the current conceptualisations of the sacred. This was to answer the question of how this concept can be understood and represented in the post-Soviet context, and to analyse post-Soviet literature and its representative Victor Pelevin as a case study. This dissertation attempts to disclose the shifts in people's mentality and their changing values as depicted and reflected in literary texts.

The post-Soviet period was chosen because it is the ultimate example of a seemingly secular society and literature, and therefore it is especially challenging to speak of 'the sacred' at all in this secular terrain. It is also an illustrative example of the changing values and identities during times of historical, political, and social turmoil. Being born in the liminal (in-between) period, post-Soviet literature discloses changing sacrality in the time of transformation. Literature is an expressive medium that can reveal otherwise obscure dimensions of the postmodern, or post-Soviet, state. It is a rich source of evidence for transitions of the sacred, serving as a barometer of society and a medium where fundamental shifts in the history of human thought are recorded. Victor Pelevin's prose was chosen as a case study because he is one of the most prominent writers in the contemporary Russia and overall is representative of this post-Soviet era. Moreover, I will argue that he can be named as a voice for this generation - those in-between the post-Soviet past and a future yet unknown. As this research will show, Pelevin's works reflect the ambiguity of the sacred. Also, his prose constructs and deconstructs the sacred at the same time.

This research contends the idea that contemporary society demonstrates not the disappearance, or degradation, as later will be stated discussing Mircea Eliade's works, but the reorganisation of the sacred. The issue of contemporary society having 'nothing sacred' seems to be born out of the false definition of the sacred as belonging exclusively to the religious field. That is how Bronislaw Szerszynski puts it:

"The illusion that the sacred has disappeared is arguably a feature of all historical transitions from one form of the sacred to the next in a given society. Each transition can seem like an eclipse of the sacred in the terms in which it was organized in the closing epoch; from a larger historical perspective, however, it can be seen as the emergence of a new sacral ordering.,"2

\footnotetext{
${ }^{2}$ Bronislaw Szerszynski, Nature, Technology, and the Sacred (Malden: Blackwell, 2005), 26.
} 
In other words, this research argues that the concept of the sacred is still crucially important in contemporary society, although it cannot be held to be universal. The aim of this dissertation is to shed light on the ambiguous interpretations of this concept, which once was, and still is, considered the key concept for religious studies. This research argues for the necessity to redefine the concept of the sacred, demonstrating that people are still searching for meaning, identity, and community; in other words, that what can be considered sacred. It also argues that this search might not have strictly religious forms but might appear in new, eclectic, experiential forms. Thus the sacred is not considered a universal phenomenon and it is not necessarily related to religion. The elusive nature of this concept requires an interdisciplinary approach. Therefore, this research draws from religious studies, literary theory, and anthropology.

The original contribution that this research will make to scholarship is first revising and broadening the concept of the sacred and applying it in the literary field, refusing to utilise it as only a religious category. Second, the results of this study will show that it is possible to talk about sacrality in a seemingly secular, post-Soviet, and, more generally, postmodern world. Thirdly, the results will allow us to track the varieties of the sacred in the post-Soviet milieu and, more importantly, to see whether this post-Soviet sacred can be more extensive and applicable in a wide variety of contexts. Lastly, this research will make a contribution to the critical appreciation of Pelevin's works.

My hope is that this research would serve as a bridge between the theoretical discussions on the sacred and a practical application of this concept in post-Soviet literature. So far no studies have been done analysing post-Soviet literature from a religious studies framework with an emphasis on the concept of the sacred. This work intends to fill that gap.

\section{Outline}

This thesis consists of seven chapters and a final concluding section.

The first chapter presents a brief history of the theoretical formulations of the sacred and its critique, arguing for the redefinition and broadening of these traditional notions. It presents a reformulated definition, which will be essential when using this concept as an analytical tool. This definition also enables the discussion of sacredness in what is often incorrectly conceived as secularised post-Soviet literature. I also discuss the benefits and potential problems of this new definition. 
The second chapter further specifies the concepts discussed in this dissertation; namely, the conventional and non-conventional modes of the sacred (the concepts of ritual (initiation and sacrifice), sacred space, time, persons, liminality, and sacred substances).

The third chapter serves for contextualisation, examining the post-Soviet condition, its historical, political, and spiritual situation, and discusses the notions of Soviet and postSoviet identities. It also provides a brief discussion of post-Soviet literature and introduces the notion of 'literature as religion.'

The fourth chapter presents Victor Pelevin in the context of post-Soviet literature and proposes that this writer can be viewed as a sacred figure, an icon in the post-Soviet milieu. Then, this chapter follows with an introduction of such concepts as 'liminal spirituality', 'deconstruction' and the 'productive void.' It further discusses liminality in Pelevin's prose and assesses the role of sacred persons and sacred space in his works.

The fifth chapter is dedicated to the conventional modes of the sacred and explores initiation and sacrifice in Pelevin's texts. The sixth and seventh chapters are dedicated to the non-conventional modes of the sacred. The sixth chapter glimpses into the sacred as escape and analyses how psychedelic substances, alcohol, and immersion in TV-mediated reality can be employed in the search for the sacred. The seventh chapter further deepens the notion of escape and discusses the ultimate manifestation of striving for an escape - the search for ultimate freedom, or liberation.

\section{Sources}

Victor Pelevin's books that are analysed in this dissertation include: Omon Ra (1992), The Yellow Arrow (1993), The Life of Insects (1993), Buddha's Little Finger (1996), Generation P (1999), Numbers (as part of the book DTP (NN) - The Dialectics of the Transition Period (from Nowhere to No Place) (2004), The Sacred Book of the Werewolf (2005), Empire V (2006), T (2009) and Pineapple Water for the Fair Lady (2011). This research is based primarily on these sources. A science fiction novel S.N.U.F.F. (2011) reached me in the final stage of writing and thus is not analysed here. Contrary to other Russian authors, Victor Pelevin has also permitted the publishing of his texts (predating 2006) on the Internet.

For quoting, I used the English translations by Andrew Bromfield (for the books The Life of Insects, Buddha's Little Finger, Generation P (translated as Homo Zapiens), and The Sacred Book of the Werewolf). For the book Omon Ra, I used the English translation by Yuri 
Machkasov. ${ }^{3}$ All other translations (such as for the books The Yellow Arrow, Empire V, T, or Pineapple Water for the Fair Lady) are mine. All quotes from the book Pineapple Water for the Fair Lady (Ananasovaya voda dlia prekrasnoy damy) are from an e-book version.

For reasons of fluidity this research will use English titles of Pelevin's books. It will also use the US title Buddha's Little Finger for the book originally published as Chapayev $i$ pustota (translated literally, Chapayev and Emptiness/Void), which was released in the UK as The Clay Machine Gun. However, it will leave the original title of the novel Generation P, which was published in the UK as Babylon and in the US as Homo Zapiens. The names of the protagonists are cited as they are most commonly used in the critical sources (for example, Pyotr in Buddha's Little Finger). Exceptions are made in the provided quotes, preserving the system followed in the source.

${ }^{3}$ http://pelevin.nov.ru/romans/en-omon/index.html (accessed September 11, 2012). 


\section{Chapter 1: What Is the Sacred?}

The introduction has presented a brief outline of how the sacred will be used in this dissertation. This first chapter will further expand the discussion of the core concept. The following sections present the emergence and historical development of the sacred, trace how this concept evolved during the $20^{\text {th }}$ century, and discuss why certain historical-genetic notions of the sacred might not correspond to the needs of the current epoch. It also emphasises the need to redefine and broaden the concept of the sacred and, finally, presents a reinvented definition of the sacred, listing its advantages and disadvantages. ${ }^{1}$

Traditionally, it has been asserted that the sacred is that which is 'set apart' (from Latin 'sacer'), or 'the holy' in theologian Rudolf Otto's terms, or 'the power', according to Dutch philosopher of religion Gerardus van der Leeuw. The sacred has been used as a synonym for religious ideas in general. It was also used as an adjective before French sociologist Emile Durkheim and historian of religions Mircea Eliade widely introduced the term as a noun. They also began the discussion of the dichotomy of the sacred and the profane. In the $20^{\text {th }}$ century, the question of this concept's essence was raised in various fields of research, including anthropology, theology, phenomenology, sociology and the psychology of religion. Critiques of religious belief and scientific rationalism demanded a more academic definition for religion and the sacred. It was also a time when the two main camps, sociological and theological, divided the battlefield for the sacred. One was led by Emile Durkheim, according to whom the sacred performs as a socially-binding element, becoming a symbolic representation of society. This is the model which William Paden later named "the sacred order.", As opposed to the profane, the sacred here serves as a category for a world classification and institutional force, binding individuals to their society. This concept maintained a strict dichotomy between the sacred and the profane, but was later

\footnotetext{
${ }^{1}$ The problem with the sacred is similar to that of religion: both these terms are subject to the critique of being ethnocentric. Critical studies of the term religion and its applicability include the works of Wilfred Cantwell Smith, Talal Asad, Russel McCutcheon, among others. Criticism concerning the applicability of the sacred is discussed further in the chapter.

${ }^{2}$ William E. Paden, "Before 'The Sacred' Became Theological: Rereading the Durkheimian Legacy," in Mircea Eliade: A Critical Reader, ed. Bryan S. Rennie (London; Oakville, CT: Equinox Pub, 2006), 69; William E. Paden, "Sacrality as Integrity: 'Sacred Order' as a Model for Describing Religious Worlds," in The Sacred and Its Scholars: Comparative Methodologies for the Study of Primary Religious Data, ed. by Thomas A. Idinopulos and Edward A. Yonan (Leiden; New York: E.J. Brill, 1996), 3-4.
} 
criticised for its reductionism, which here refers to an analysis of religion that is not in religious, but in secular terms.

The other camp was represented by Rudolf Otto, Mircea Eliade, Nathan Söderblom and other scholars of religion, who shared the viewpoint that William Paden later named "the mana model." 3 The sacred for them is understood in terms of the 'wholly other', the transcendent phenomenon, which cannot be explained empirically. It is held as a synonym for defining a supernatural object, to which humans then respond with religious behaviour. The sacred here is the very essence of religion, a sui generis ontological category. Used as a synonym for transcendental power, this concept was later criticised for being too theological.

This chapter presents the third viewpoint or, to put it symbolically, the middle path of the sacred, as formulated by W.E. Paden. ${ }^{4}$ Overall, this research adheres to the idea that for scholars of religions, this concept should be a methodologically defined tool or, as Anttonen Veikko puts it, a technical term in the scholarly study of religion and society. ${ }^{5}$ This viewpoint, as well as the definition of the sacred that is used in this dissertation, will be thoroughly discussed in the last section. Meanwhile, the next sections present how the concept of the sacred has been evolving during the $20^{\text {th }}$ century, providing a historical overview of the classical authors and a critique of both theological and sociological camps.

\subsection{A Brief History of the Sacred}

Western societies started using the concept of the sacred in the late $19^{\text {th }}$ century. This was the birth of modern times, taking modernity as both a historical and philosophical term and emphasising its faith in science, rationalism and new technologies - all of which were changing the old world. The industrialisation of society (and hence the need to explain the new processes), the professionalisation of science, the lessening importance of traditional religions as a social force and a source of knowledge about the meaning of life and human nature, resulted in the emergence of various new disciplines and ideas. The study of religion

\footnotetext{
${ }^{3}$ Ibid.

${ }^{4}$ Paden, "Before 'The Sacred' Became Theological," 77.

5 Veikko Anttonen, "Sacred," in Guide to the Study of Religion, ed. Willi Braun and Russell T. McCutcheon (London; New York: Cassell, 2000), 274.
} 
emerged in post-Enlightenment Europe, as there was a need to explain religion scientifically as a natural phenomenon as opposed to a divine phenomenon. ${ }^{6}$

This was a time when the Christian theological perspective was no longer seen as being exclusive. Responding to a need to create a dialogue with modern times, the science of religion emerged and divided into various branches, including the psychology, sociology, and anthropology of religion. The attempt at a scientific (as opposed to a divine) explanation gave birth to such disciplines as anthropology (William Robertson Smith, Edward Burnett Tylor, Bronislav Malinowski), psychoanalysis (Sigmund Freud and later Carl Gustav Jung), and sociology (Karl Marx, Max Weber, Emile Durkheim). Although being different, these disciplines had at least one thing in common - they did not appeal to any transcendent reality when searching for explanations. Rather than reducing religion to superstitions of 'primitive' societies as in the rationalist critique by the $18^{\text {th }}$ century Enlightenment, they began to use analytical tools to talk about it.

Although Durkheim's The Elementary Forms of Religious Life was first published in 1912 (some ten years after the publishing of another prominent book The Varieties of Religious Experience (1902) by William James), the latter had a completely different intellectual framework. Based on James' Gifford lectures, The Varieties of Religious Experience was an important contribution to the emerging field of the psychology of religion. Although James concentrated on the religious experience, and thus can be compared to Rudolf Otto, for him the religious experience arose not from the 'wholly other', but from the human being. While James focused on the personal religious experience, defining religion as "the feelings, acts, and experiences of individual men in their solitude, so far as they apprehend themselves to stand in relation to whatever they may consider the divine", 7 viewing religion as a universal phenomenon and criticising reductionist approaches, Durkheim's primary interest was the social order and the role of religion and the sacred in society. For him religion was "a unified system of beliefs and practices relative to sacred things, that is to say, things set apart and forbidden - beliefs and practices which unite into one single moral community called a Church, all those who adhere to them." ${ }^{8}$ That is,

\footnotetext{
${ }^{6}$ Willi Brown, "Religion," in Guide to the Study of Religion, ed. Willi Braun and Russell T. McCutcheon (London; New York: Cassell, 2000), 13.

${ }^{7}$ William James, The Varieties of Religious Experience: A Study in Human Nature, Being the Clifford Lectures on Natural Religion Delivered at Edinburgh in 1901-1902 (New York: Longmans, Green, and Co., 1902$), 31$.

${ }^{8}$ Emile Durkheim, The Elementary Forms of Religious Life, trans. by Carol Cosman (New York: Oxford University Press, 2001), 47.
} 
Durkheim defined religion in terms of the sacred, not the sacred in terms of religion. ${ }^{9}$ This was a very important shift away from the sacred as an individual experience to its role of binding society, paving the way for further sociological or anthropological implications. ${ }^{10}$ Durkheim's theory will be further discussed in the subsequent sections.

The fact that Rudolf Otto's book appeared only five years after The Elementary Forms of Religious Life illustrates the blossoming plurality of perspectives in the scholarly field of religious studies. Das Heilige (1917), translated by John W. Harvey as The Idea of the Holy (1923), gave birth to the scholarly discussion around the concept of the sacred, establishing the previously mentioned mana model and influencing those who later approached this concept, including Mircea Eliade and Gerardus van der Leeuw. Although written almost 100 years ago, this book is still important, and no research on the sacred could proceed without mentioning it. ${ }^{11}$

Earlier contributions also come from Swedish archbishop Nathan Söderblom, ${ }^{12}$ who stated that holiness is more essential to religion than the notion of god. ${ }^{13}$ The distinction between the holy and the profane for him was fundamental to all religious life. ${ }^{14}$

But it was Mircea Eliade who popularised the term 'sacred' and diagnosed a decline of the sacred in modern society. ${ }^{15}$ Gerardus van der Leeuw also contributed to this field with his book Religion in Essence and Manifestation (1963), considered to be a classic text of the phenomenology of religion. He proposed the term power instead of the sacred or the holy, as according to him this term would be more fundamental and therefore cross-culturally useful. Otto's influence is evident in his works. Trying to define Otto's 'wholly other', van der Leeuw describes it as a religious experience: "strange, 'Wholly Other', Power obtrudes into

\footnotetext{
${ }^{9}$ Elizabeth Burns Coleman and Kevin White, "Stretching the Sacred," in Negotiating the Sacred: Blasphemy and Sacrilege in a Multicultural Society, ed. Elizabeth Burns Coleman and Kevin White (Canberra: Anu E Press, 2006), 68.

${ }^{10}$ The followers of Durkheim, Henri Hubert and Marcel Mauss published their socio-anthropological analysis in Sacrifice: Its Nature and Function (1899). In this work they claimed that ritual is essential in creating and maintaining the sacred realm, and that sacrifice is a special kind of ritual, which serves for linking the sacred and profane worlds through the victim who is destroyed during a certain ceremony.

${ }^{11}$ More about Rudolf Otto - in section 1.2.

12 Söderblom's works include his prominent article Holiness, in Encyclopaedia of Religion and Ethics (1913), and Living God: Basal Forms of Personal Religion (London: Oxford University Press, 1939).

13 "Holiness is the great word in religion; it is even more essential than the notion of God. Real religion may exist without a definite conception of divinity, but there is no real religion without a distinction between holy and profane." (Nathan Söderblom, quoted from John Rogerson, "What is Holiness?" In Holiness Past and Present, ed. Stephen C. Barton (London; New York: T \& T Clark, 2003), 6-7.)

${ }^{14}$ However, being a Lutheran churchman, Söderblom believed in the uniqueness and superiority of Christianity compared to the other religions. Therefore he is also subject to the critique as being 'too theological' for the religious studies scholarship.

${ }^{15}$ An extensive discussion of Eliade's ideas is presented in section 1.3.
} 
life." ${ }^{\prime 16}$ Humans react towards this power first with astonishment and then with faith. Van der Leeuw also claims that 'the power' has universal applicability and is present throughout all forms of religious ritual or when ritual is transgressed. ${ }^{17}$

Roger Callois provided an overview of various expressions of the sacred in his book Man and the Sacred. ${ }^{18} \mathrm{He}$ presented the sacred as evoking and stimulating ambivalent feelings. It is awe and aversion (an allusion to Rudolf Otto), taboo and desire, and forces that are both constraining and liberating. Callois depicts an ambiguous attitude towards the sacred, analysing its polarity, that which is both tabooed and that which is erasing the previous boundaries in the community. He emphasises the need for purification before entering the sacred world: "The human must be abandoned before the divine can be reached," 19 noting also the reversibility of the pure and impure, which was thoroughly discussed by Mary Douglas. ${ }^{20}$

The topics of the sacred and sacrifice are covered in French literary critic and anthropologist René Girard's book Violence and the Sacred. ${ }^{21}$ According to Cesareo Bandera, it can be said that Girard's theory on the sacred starts where Durkheim's left off. ${ }^{22}$ He notes that "if in Durkheim the social is the soul of the sacred, in Girard the sacred is the very soul of the social." 23 According to Girard, sacrifice is an act of violence performed on a surrogate victim - this is what Girard calls the surrogate victim mechanism. That victim can be later hailed as a bearer of peace, a sacred figure. ${ }^{24}$ Thus the sacred is manifested as violence directed at a sacrificial victim. The victim is sacred: it renews order and peace in the

\footnotetext{
${ }^{16}$ Gerardus van der Leeuw, "Religion in Essence and Manifestation," in Theories of Religion: A Reader, ed. Seth Daniel Kunin and Jonathan Miles-Watson (New Jersey: Rutgers University Press, 2006), 136.

${ }^{17}$ John Daniel Dadosky, The Structure of Religious Knowing: Encountering the Sacred in Eliade and Lonergan (New York: State University of New York Press, 2004), 19.

${ }^{18}$ Roger Callois, Man and the Sacred, trans. by Meyer Barash (Urbana: University of Illinois Press, 2001).

${ }^{19}$ Ibid., 39.

${ }^{20}$ In Mary Douglas, Purity and Danger: An Analysis of Concepts of Pollution and Taboo (London: Routledge \& Kegan Paul, 1969).

${ }^{21}$ René Girard, Violence and the Sacred, trans. by Patrick Gregory (Baltimore: Johns Hopkins University Press, 1977). More about Girard's theory concerning sacrifice - in the second and fifth chapters.

${ }^{22}$ In the book The Sacred Game: The Role of the Sacred in the Genesis of Modern Literary Fiction, Cesareo Bandera concentrates on Girard's anthropological insights and analyses the role of the sacred in modern literary fiction. Amongst other ideas, he presents the opposition of the 'old sacred' and Christianity instead of the opposition between Christianity and the secular world. He denies that the modern human lives in a desacralised world because of his rejection of the sacred, and instead claims that it is because of the influence of the Christian text. So Bandera's argument is that "there is no such thing as a conflict between Christianity and a purely 'secular', nonreligious man, but only between Christianity and the old sacred" - a kind of neo-pagan mode of thought. (Cesareo Bandera, The Sacred Game: The Role of the Sacred in the Genesis of Modern Literary Fiction (University Park, PA: Pennsylvania State University Press, 2004), 16.)

23 Ibid., 19.

${ }^{24}$ Leo D. Lefebure, "Victims, Violence and the Sacred: The Thought of René Girard," Christian Century 113 , no. 36 (1996): 1226.
} 
community. ${ }^{25}$ According to Girard, the birth of religion can be explained through the mechanism of violence and sacrifice. The sacred arose out of sacrifice, which puts an end to the profane cruelty in society.

The following sections will present Rudolf Otto, Mircea Eliade, and Emile Durkheim as the most important classical authors for the discussion on the sacred, emphasising their contributions to the clarification of this concept, pointing to the criticisms and discussing whether their arguments are still relevant in the contemporary scholarship.

\subsection{Rudolf Otto and the 'Wholly Other'}

One of the foremost German theologians, Rudolf Otto is best known to the scholars of religion and society for his book The Idea of the Holy. Melissa Raphael states that "for nearly 80 years this text has been used as a yardstick against which subsequent studies of holiness have declared and defined their own position." ${ }^{, 6}$ There are claims that this text can be called one of the most successful German theological books of the $20^{\text {th }}$ century. ${ }^{27}$ Lynn Poland notices its "curious doubleness", adding that this work is not only about religion, but is also religious writing. ${ }^{28}$ There is another doubleness concerning Otto's The Idea of the Holy; namely, two different histories of its interpretation. After being criticised and forgotten, Otto's book was rediscovered in the middle of the $20^{\text {th }}$ century, hence the two different interpretations of Otto's theory. ${ }^{29}$

\subsubsection{The Holy, the Sacred, and the Sublime}

Although the holy and the sacred are sometimes used as synonyms, they are not synonyms in the strict sense of the word. Three main meanings of the term 'holy' can be distinguished: first, the attributes of god or the divine; secondly, the attributes of things that derive their holiness from their association with god; thirdly, the attributes of people and

\footnotetext{
${ }^{25}$ Girard, Violence and the Sacred, 1.

${ }^{26}$ Melissa Raphael, Rudolf Otto and the Concept of Holiness (Oxford: Clarendon Press, 1997), 1.

${ }^{27}$ For example, Todd A. Gooch states that it is probably the most widely read German theological work of the $20^{\text {th }}$ century. (Todd A. Gooch, The Numinous and Modernity: An Interpretation of Rudolf Otto's Philosophy of Religion (New York: W. de Gruyter, 2000), 1.)

${ }^{28}$ Lynn Poland, "The Idea of the Holy and the History of the Sublime," Journal of Religion 72, no. 2 (1992): 175.

${ }^{29}$ This thesis will concentrate on the contemporary reception of Otto, and will also discuss Eliade's viewpoint.
} 
actions held to be the god's expectation. ${ }^{30}$ Hence the term 'holy' is used either to define moral categories attributed to the characteristics of god, or to divine participation. The sacred can be considered with regard to a religious community as an outsider's term, whereas the holy is more exclusively an insider's term. ${ }^{31}$ With the context of Otto's works in mind, the choice of 'the holy' is neither surprising nor out of place. Therefore, in this research the holy will not be used synonymously with the sacred, avoiding any moral/value/theological connotations. The same can be said about the term 'sublime'. Lynn Poland contextualised Otto in the history of the sublime and argued his ambivalent attitude towards this term: "Otto himself evokes the sublime as virtually identical in structure and content to the numinous, only to demote it to the status of mere, albeit central, analogy. $" 32$

The choice of the word 'heilige' is justified arguing that the words 'holiness' and 'sanctity' are already charged with ethical or moral connotations that are secondary in the context of Otto's book. These words point to moral or ethical categories rather than define the ultimate meaning which should be separated from the notions such as 'goodness'. Although these categories are also present in the concept of holiness, there is one more element, the one that remains after excluding the moral and ethical issues. The word necessary for replacing and rescuing the term 'holy' from the moral connotations, should "stand for this element in isolation, this 'extra' in the meaning of the 'holy' above and beyond the meaning of goodness." 33

This surplus of meaning that, as Otto claims, is a unique a priori category of value, is then named as "the numinous" (from Latin word "numen" cf. "ominous" from "omen"), meaning, as Russel T. McCutcheon notes, a force or power identified with natural objects and sometimes understood as "holy". 34 The feeling of the numinous cannot be taught, a person either feels it or not; it can only be awakened "as everything that comes 'of the spirit'." 35 This experience can be neither defined nor conceptualised, it is irreducible in nature. Otto argues that those who are not capable of remembering any religious experience are also incapable of awakening numinous feelings, hence his famous, widely cited phrase: "Whoever cannot do this, whoever knows no such moments in his experience, is requested to read no further.",36

\footnotetext{
${ }^{30}$ Encyclopaedia of Religion, $2^{\text {nd }}$ ed., s. v. "Holy, Idea of The."

${ }^{31}$ Ibid.

${ }^{32}$ Poland, "The Idea of the Holy and the History of the Sublime," 176.

${ }^{33}$ Rudolf Otto, The Idea of the Holy: An Inquiry Into the Non-Rational Factor in the Idea of the Divine and Its Relation to the Rational (New York: Oxford University Press, 1950), 7.

${ }^{34}$ Russell T. McCutcheon, Studying Religion: An Introduction (London; Oakville, CT: Equinox Pub., 2007), 169.

${ }^{35}$ Otto, The Idea of the Holy, 7.

${ }^{36}$ Ibid., 8.
} 
The outsiders to this experience should not interfere in the sphere where experience is more important than rational implications. Thus not only can the holy itself be neither explained nor defined; its experience is also beyond any definition. Presenting the phenomenological description of the religious experience, Otto strictly separates it from the rational sphere. Claiming that religion is sui generis and therefore a category completely in itself, he rejects the possibility of analysing these religious phenomena with the help of linguistic analysis, anthropology, sociology, psychology and historical approaches. In summary, according to Otto, religious phenomena need a special autonomous approach.

The experience of the numinous is described by Otto as "the deepest and most fundamental element in every strong and sincerely felt religious emotion," that can "come sweeping like a gentle tide, pervading the mind with a tranquil mood of deepest worship," lasting until "it dies away and the soul resumes its 'profane', non-religious mood of everyday experience." 37 He names these feelings the mysterium tremendum et fascinans awesome/awful, majestic, mysterious, and urgent, which attract and frighten at the same time.

Emphasising the necessity of deepening our rational conception of god or the numinous, Otto considers the holy as both an a priori category of the mind and as manifesting itself in outward appearance. ${ }^{38}$ The holy reveals itself in Otto's work as an ultimate goal and meaning of all religions, as irrational, fascinating, unquestionable and unexplainable, independently of whether and how people see it or not. Since the holy is the 'wholly other', one cannot experience it directly, only through texts, natural wonders, ecstatic states, those that can point beyond themselves to a certain transcendental sacred reality.

\subsubsection{Critical Accounts}

Although Otto argues that the holy is universal to all religions and all religions contain elements of the numinous, just in varying degrees, this notion is criticised as too theological: "Otto regards all religions as responses to the one, archetypical numina. In his view, religious ideas are more than a mode of thought, they are 'archetypal images' which stem from the "collective unconsciousness' of the human race." 39

\footnotetext{
${ }^{37}$ Ibid., 12-13.

${ }^{38}$ Ibid., 179.

${ }^{39}$ Clinton Bennett, In Search of the Sacred: Anthropology and the Study of Religions (London; New York: Cassell, 1996), 92.
} 
Too much a historian of religion for the theologians, and too much a theologian for the historians of religion, in Philip Almond's words, ${ }^{40}$ Rudolf Otto was criticised for his personal, Christian, theological intentions in formulating his notion of the sacred, which is itself too narrowly conceived. Rather than analysing the broad variety of historical and cultural forms of religious phenomena, he focused on the non rational experiences of the 'wholly other'. For Otto, the religious experience and the experience of the numinous was far more important than historical implications. Colin Crawder notes that recent textbooks rarely mention the importance of Otto's works, accepting instead the view that it is "an essay in the phenomenology of religion with a limited theological significance." ${ }^{, 1}$ Furthermore, he argues that Otto's book was not exceptionally original and its distinctiveness is in the way the ideas are put into a whole.

In the introduction of The Sacred and the Profane, Mircea Eliade noted that Otto concentrated not on god or religion, but on the modalities of the religious experience. The quote from the introductory part is an eloquent account on Eliade's point of view, which will be analysed further in this research:

“After forty years, Otto's analyses have not lost their value; readers of this book will profit by reading and reflecting on them. But in the following pages we adopt a different perspective. We propose to present the phenomenon of the sacred in all its complexity, and not only so far as it is irrational. What will concern us is not the relation between the rational and non rational elements of religion but the sacred in its entirety.",42

This passage can be interpreted both as a tribute to and a critique of Otto's input to the scholarly study of the sacred. Crowder claims that by focusing on the "irrational" aspect of Otto's theory of the holy, Eliade is not being objective. By stressing this aspect, Eliade possibly wanted to distinguish his own theory of the sacred and present it as an original notion. Crowder even claims that Eliade intentionally did not mention other aspects of Otto's works, thus providing his reader a rather narrow understanding of The Idea of the Holy. ${ }^{43}$

However, in defence of Otto it needs to be noted that The Idea of the Holy was not supposed to be an end result of the study on the sacred. Robert F. Streetman draws our attention to the fact that this book was meant to be a starting point for such a study that Otto

\footnotetext{
${ }^{40}$ Philip Almond, quoted from Colin Crowder, "Rudolf Otto's The Idea of the Holy Revisited," in Holiness Past and Present, ed. Stephen C. Barton (London; New York: T \& T Clark, 2003), 34.

41 Ibid., 24.

${ }^{42}$ Mircea Eliade, "Introduction to the Sacred and the Profane," in Mircea Eliade: A Critical Reader, ed. Bryan S. Rennie (London; Oakville, CT: Equinox Pub, 2006), 18.

${ }^{43}$ Crowder, "Rudolf Otto's The Idea of the Holy Revisited," 39.
} 
intended to pursue later. ${ }^{44}$ Many of Otto's essays are still not translated into English and thus were not properly analysed. Also, his comparative works are not taken into account. ${ }^{45}$ Finally, Otto's text was meant to be a 'book for insiders', as he himself stressed, and should be regarded as such.

With this being said it has to be admitted though that Otto's concept of the holy is hardly applicable in contemporary scholarship. His viewpoint now seems ethnocentric, too deeply rooted in the Judaeo-Christian paradigm. Both Otto and later Eliade treat the sacred as a sui generis category, an 'other worldly' phenomenon. The sacred for them is a universal category, which can be regarded only in the context of religion. However, Otto's book is useful as a historical account of the development of this concept. Otto's scholarly work also presents an opportunity to discuss the contrast between the classical mana model and the sociological interpretation of the sacred. This contrast enables us to raise new questions and find new definitions of the sacred, attempting to create - once again repeating William E. Paden's words - a middle path for studying the sacred. The next section discusses another representative of this mana model and his main arguments.

\subsection{Mircea Eliade and the Golden Age of the Sacred}

The debate on Mircea Eliade's life and his impressive legacy continues up to the present - from the discussions on whether Eliade's method was phenomenological or theological, to the accusations of his infamous political views. ${ }^{46}$ Throughout his lifework this Romanian-born author and scholar of religious studies argued about the universality of religion and religiosity as innate to humans. As Terence Thomas notes, the sacred for Eliade is not only essential to the understanding of religion, but also to the understanding of reality. ${ }^{47}$ In other words, religion is based on the experience of the sacred. Eliade tried to explore, in his own words, the changing morphology of the sacred. He believed that this concept is universal, a basic element for the human being. Meanwhile, according to him, the

\footnotetext{
${ }^{44}$ Robert F. Streetman, "Some Later Thoughts of Otto on the Holy," Journal of the American Academy of Religion 48, no. 3 (1980): 370.

${ }^{45}$ Such as Mysticism East and West: A Comparative Analysis of the Nature of Mysticism (New York: The Macmillan Company, 1932).

${ }^{46}$ From the number of books by this scholar the most relevant to this discussion are The Sacred and the Profane (1957), The Myth of the Eternal Return (1954), and Patterns in Comparative Religion (1949).

${ }^{47}$ Terence Thomas, "The Sacred' as a Viable Concept in the Contemporary Study of Religions," in Religion: Empirical Studies, ed. Steven Sutcliffe (Aldershot: Ashgate, 2004), 57.
} 
sacred and profane are the two modes of being or experiencing the world, which constitute existence.

If religion for Eliade is the experience of the sacred, then what is the sacred itself? "The sacred and profane are two modes of being in the world, two existential situations assumed by man in the course of his history," notes Eliade in his introduction to the book The Sacred and the Profane. ${ }^{48}$ The sacred for Eliade is a complex concept. It is, first and foremost, that what is opposite to the profane. The sacred and the profane thus define the two modalities of experience. John Rogerson briefly summarised Eliade's definitions of the sacred:

"First, it is an organisational concept, defined in opposition to the profane. Secondly, it is a perceived quality, being 'equivalent to a power and, in the last analysis, to reality.' Thirdly, it has an existential sense in that 'the sacred and profane are two modes of being in the world, two existential situations assumed by man in the course of his history.' Finally, it is an ontological reality which manifests itself in what Eliade calls hierophanies, i.e. 'manifestations of sacred realities'."49

Hierophanies are the only way the sacred - the 'wholly other' - can manifest in the profane, historical space. "The sacred tree, the sacred stone are not adored as stone or tree; they are worshipped precisely because they are hierophanies, because they show something that is no longer stone or tree but the sacred, the ganz andere." ${ }^{50}$ Here is how Eliade puts it:

"It could be said that the history of religions - from the most primitive to the most highly developed - is constituted by a great number of hierophanies, by manifestations of sacred realities. From the most elementary hierophany - e.g., manifestation of the sacred in some ordinary object, a stone or a tree - to the supreme hierophany (which, for a Christian, is the incarnation of God in Jesus Christ) there is no solution of continuity. In each case we are confronted by the same mysterious act the manifestation of something of a wholly different order, a reality that does not belong to our world, in objects that are an integral part of our natural 'profane' world." 51

When manifesting the sacred, the natural object, the thing, the ritual activity turns into the 'wholly other', yet also remains itself. Eliade argues that the entire cosmos can become a hierophany. In the article The Structure and Morphology of the Sacred he also adds that we

\footnotetext{
${ }^{48}$ Eliade, "Introduction to the Sacred and the Profane," 20.

${ }^{49}$ Rogerson, "What is Holiness?" 13.

${ }^{50}$ Eliade, "Introduction to the Sacred and the Profane," 19.

${ }^{51}$ Mircea Eliade, The Sacred and the Profane; the Nature of Religion, trans. by Willard R. Trask (New York: Harcourt, 1959), 11.
} 
should get used to recognizing hierophanies everywhere, in every area of psychological, economic, spiritual, and social life. Moreover, according to him, "it is unlikely that there is any animal or any important species of plant in the world that has never had a place in religion." ${ }^{, 52}$ The archaic societies used to make their world sacred, to create the cosmos out of the chaos when inhabiting a territory, to surround themselves with the manifestations of the sacred. It is reflected in the symbolism of the centre (and temples as the centres of the world'), in rituals which enable us to return to the sacred time, and in the repetitions of the actions of heroes, gods or ancestors that took place in illo tempore. Every hierophany, though marking the sacred reality, is also a historical fact and takes place in a historical situation.

\subsubsection{The Sacred in Modernity}

Depicting the sacred in the secular world, Eliade states: "If the sacred means being, the real, and the meaningful, as I hold it does, then the sacred is a part of the structure of human consciousness." ${ }^{, 53}$ However, according to him, together with the disappearance of the 'primitive' human, gone is the ability of the modern human to fully experience the sacred. Being the result of the process of desacralisation, the modern non-religious human regards the sacred as an obstacle to gain his freedom. He "will not be truly free until he has killed the last god," 54 regarding beliefs of the ancestors as superstitions, and trying to escape from them.

According to Eliade, the golden age (of the sacred) is over, and with the modernisation process, the sacred experiences degradation and emerges only through some kind of degenerated, unconsciously performed rituals. However, if the sacred is a part of the structure of human consciousness, it could not disappear permanently. The modern human cannot escape earlier models of ancestors' behaviour although he desperately tries to. That behaviour is, in Eliade's terms, "emotionally present" in that human, "ready to be reactualized in his deepest being." 55 As he puts it, "I am convinced that whatever modern, secularized man might think of himself, he still occupies a sacred dimension." ${ }^{, 56}$ The modern

\footnotetext{
52 Mircea Eliade, "The Structure and Morphology of the Sacred," in Mircea Eliade: A Critical Reader, ed. Bryan S. Rennie (London; Oakville, CT: Equinox Pub, 2006), 45.

${ }^{53}$ Mircea Eliade, "The Sacred in the Secular World," in Mircea Eliade: A Critical Reader, ed. Bryan S. Rennie (London; Oakville, CT: Equinox Pub, 2006), 58.

${ }^{54}$ Eliade, The Sacred and the Profane, 203.

55 Ibid., 204.

${ }^{56}$ Eliade, "The Sacred in the Secular World," 58.
} 
human desacralised the world and changed his behaviour. Yet the old models of behaviour and that "emotional presence" prevent him from the total desacralisation, and this is the reason why the non-religious human still behaves religiously (consciously or unconsciously) and has some hidden mythology and a lot of degraded rituals. Although agreeing that a modern human has certain objects which he holds dear and sacred (for example, certain places, like his birthplace), Eliade interprets them as the degraded forms of religious behaviour, completely dismissing any non-religious interpretations. ${ }^{57}$

Regarding the contemporary world as a degraded place, Eliade clearly states that he does not believe in the ability of modern people to fully experience the sacred. For him, the wholly profane cosmos with nothing sacred is merely a recent discovery in the history of the human spirit. The sacred in modern society is camouflaged and almost unrecognizable. ${ }^{58}$ However, using his general theory on myth and religion, Eliade uncritically applies it to the explanation and interpretation of the contemporary world. Here his perspective is clearly religious and sometimes, as Douglas Allen states, "downright reactionary." further, Eliade "does not hesitate to make personal and scholarly judgements about the economic, political, social, and historical planes of reference." 60

As this research does not limit the sacred to only the religious realm, Eliade's arguments of essential nature fail to stand up to criticism. The next section provides a further critique of his theory.

\subsubsection{Critical Accounts}

"Maybe we are at the end of the Eliadean era and, grateful for his great contributions, are also turning to new questions and themes," states Ninian Smart, summing up Eliade's

\footnotetext{
${ }^{57}$ Eliade, The Sacred and the Profane, 24.

${ }^{58}$ Eliade also claims that a modern human cannot live without the dimension of the 'wholly other' and the ideas of transcendence. In the article The Sacred in the Secular World, which was published in 1973 (based on a paper given in 1968), he speaks about the possibility of a new religious expression, "which cannot yet be recognized as such, simply because it is something completely new, just because we speak of the new consciousness in purely humanistic terms, this does not mean that the new consciousness is not a continuation of what being is meaning, a social being, and so on." (Eliade, "The Sacred in the Secular World," 60.) Not only "degraded rituals' and unconscious repetitions, but also a qualitatively new understanding which is just emerging, in his words. For Eliade, that emerging sacred could surface in secular culture through art (Picasso's Guernica as an example). He claims that the creative possibilities of the modern human are nourished not by his rationalistic universe, but by his unconscious, by an imaginary universe. Non-religious people discover the sacred through art, culture, and dreams.

${ }^{59}$ Douglas Allen, Myth and Religion in Mircea Eliade (New York: Routledge, 2002), 269.

${ }^{60}$ Ibid.
} 
legacy. ${ }^{61}$ Roger Corless goes even further describing all of Eliade's lifework as a failure, though magnificent and invaluable, similarly "of the Michelson-Morley experiment to find ether, which opened the way for us to discover electro-magnetic radiation."

Amongst the harshest critics is Russell McCutcheon, not only proclaiming the end of the Eliadean era, but also emphasising the necessity to redefine the term of religion itself. ${ }^{63}$ He also criticises the notion of religion as a privileged place for the sacred that is evident in Eliade's works. Eliade held the sacred as a concept belonging only to the religious studies field, a notion that is rejected in this research. Although he declared the universal nature of the sacred, his suggested tool for interpreting the relation between humans and religion represents only one theological viewpoint.

Like his contemporaries, Eliade held on to the idea that one must look at the "simplest", "primitive" forms of religious life in order to reveal the religious phenomena in their primary, least affected forms. He asserted, "Before you attempt any definition of the phenomenon of religion, you must know where to look for the evidence, and, first and foremost, for those expressions of religion that can be seen in their 'pure state' - that is, those which are 'simple' and as close as possible to their origins." ${ }^{64}$ Hence he (as well as Durkheim) sticks to the notion that archaic communities represent a golden age of humanity, an age of the unity with the sacred, which is now permanently lost. Thus in his romanticised version, archaic cultures provide the best possibility for religious scholars to explore the manifestations of the sacred. The archaic human, according to Eliade, would be the only one who used to have contact with the sacred and could recognise the manifestations of the sacred reality. In Daniel Dubuisson's words - "fundamentally religious" and obsessed by the ontic. ${ }^{65}$ Dubuisson goes even further saying that Eliade neither expands nor conceptualises his propositions. All his reader has to do is to believe. Therefore, the sacred for Eliade becomes "simply a conventional way to indicate ultimate Reality; the inexpressible and absolutely transcendent Being that is revealed to humanity by means of hierophanies.",66

\footnotetext{
${ }^{61}$ Ninian Smart, "Review of Mircea Eliade (ed.), The Encyclopedia of Religion," in Religious Studies Review 14, no. 3 (1988): 197.

${ }^{62}$ Roger Corless, "Building on Eliade's Magnificent Failure," in Changing Religious Worlds: The Meaning and End of Mircea Eliade, ed. Bryan S. Rennie (Albany: State University of New York Press, 2001), 4.

${ }^{63}$ Russel McCutcheon, "Methods, Theories and the Terrors of History," in Changing Religious Worlds: The Meaning and End of Mircea Eliade, ed. Bryan S. Rennie (Albany: State University of New York Press, 2001), 11-23.

${ }^{64}$ Eliade, "The Structure and Morphology of the Sacred," 42.

${ }^{65}$ Daniel Dubuisson, Twentieth Century Mythologies (London: Equinox, 2006), 195.

${ }^{66}$ Ibid., 194.
} 
Eliade is accused of being methodologically uncritical, presenting subjective generalisations that are not based on empirical or historical data, speaking in essentialistic and essentialising terms, as well as inaccuracy. Like Otto, Eliade is essentialising; for him the sacred is merely an a priori category expressed symbolically by homo religiosus. It is irreducible and universal, the very essence of the religious experience and unexplainable other than in religious terms. One must speak about religion "religiously", and the sacred can only be studied as something "religious". ${ }^{67}$ Religion for him, as for Otto, could not be reduced to historical, psychological or social factors.

Allen also argues that most of Eliade's notions are to be believed and come without any proof. Eliade emphasised the importance of the unconscious in his writings, and claimed that symbols and myths can "communicate their meanings even when religious persons are unaware of them." 68 Hence his task was to uncover the unconscious meanings of the consciously profane behaviour of the modern human. Eliade keeps mentioning a certain homo religiosus, but they, as Allen critiques, are detached from any empirical data and exist primarily in Eliade's head. However, Allen also recognises a certain value of Eliade's ideas, though warning that some flaws have to be taken into account beforehand; namely, that Eliade, "dismisses or devalues achievements of modernity; that he excludes the voices of many 'others' suppressed by the modern West; and that he does not address how 'others' have been and still are suppressed in traditional religious cultures." ${ }^{\prime 69}$ This all points to Eliade's typical West-centric attitude, limited understanding of 'the other', dismissing race and gender issues or a variety of different cultures or 'primitive' societies, romanticising the past and seeing only the negative sides of the modernity.

Although Bryan S. Rennie argued that Eliade was more influenced by Durkheim than Otto in creating the concept of the sacred, proving this argument with the dialectic of the sacred and the profane, John Daniel Dadosky claims that Otto's Idea of the Holy had a significant influence on Eliade's notion of the sacred. ${ }^{70}$ However, it is evident that Eliade was indebted to both. On the other hand, William E. Paden argues that we cannot simply reduce him to a theologian:

\footnotetext{
${ }^{67}$ Russell T. McCutcheon, Manufacturing Religion: The Discourse on Sui Generis Religion and the Politics of Nostalgia (New York: Oxford University Press, 1997), 53.

${ }^{68}$ Allen, Myth and Religion in Mircea Eliade, 37.

${ }^{69}$ Douglas Allen, "Mircea Eliade's View of the Study of Religion as the Basis for Cultural and Spiritual Renewal," in Changing Religious Worlds: The Meaning and End of Mircea Eliade, ed. Bryan S. Rennie (Albany: State University of New York Press, 2001), 231.

${ }^{70}$ Dadosky, The Structure of Religious Knowing, 22.
} 
"I would argue that the sacred for Eliade is primarily (though not exclusively) a value found in objects, rather than a reified, independent reality. As if that is not heretical enough, I would also maintain that his notions about 'studying religion at its own level' do not mean that scholars need to assert or intuit a metaphysical reality, but rather that they need to identify the specific, characteristic kinds of objects and responses to them engaged by religious people."

Paden distinguishes the two voices of Eliade: that which seems to be associating the sacred with Otto's 'wholly other' speaks about the transcendence of the sacred and thus might seem outdated; and that which is "not theological at all, but postfoundationalist and to some extent postmodern," 72 which could be relevant for the present scholarship. However, due to the scope of this research, these critical accounts are not discussed further.

Despite the critique discussed above, the richness of Eliade's texts is alluring, his broad perspective and attractive style is inspiring, and his legacy is still important in shaping the concept of the sacred, serving as historical evidence of this changing concept. The next section presents yet another version of this concept, the sacred order by Emile Durkheim.

\subsection{Emile Durkheim and Society as Sacred}

Although Emile Durkheim's major work The Elementary Forms of Religious Life was first published almost 100 years ago, its influence is still present in the scholarly fields of sociology, anthropology, and religious studies. Although Mircea Eliade regarded Durkheim as a "master of reductionism" and ignored his notion on the dichotomy of the sacred and the profane in The Sacred and the Profane, sociological reductionism is only one aspect of Durkheim's thought. Durkheim refused to narrow down religion to individual experiences and analysed instead its institutional meaning and functions. The sacred for Durkheim is an institutional concept, which could only be actualised in a particular society and which stretches beyond the boundaries of religion. As it was already mentioned, Durkheim defined

\footnotetext{
${ }^{71}$ William E. Paden, "The Creation of Human Behaviour: Reconciling Durkheim and the Study of Religion," in Reappraising Durkheim for the Study and Teaching of Religion Today, ed. Thomas A. Idinopulos and Brian C. Wilson (Leiden; Boston: Brill, 2002), 20.

${ }^{72}$ William E. Paden, "The Concept of World Habitation: Eliadean Linkages with a New Comparativism," in Changing Religious Worlds: The Meaning and End of Mircea Eliade, ed. Bryan S. Rennie (Albany: State University of New York Press, 2001), 250.
} 
religion in terms of the sacred, not the sacred in terms of religion. Religion for him was not about beliefs in god or gods, but about the distinction between the sacred and the profane. ${ }^{73}$

Durkheim based his study on the data gathered from the Australian Arunta totemic tribe, assuming that the answers about the nature and meaning of religion could be found in such simplistic (avoiding the word 'primitive') ${ }^{74}$ forms, analysing the nature of the archaic mind. Durkheim noticed that rituals, in which tribe members took part, made an essential distinction between the sacred and the profane: they divided the world into two polarities. However, the sacred things are the same as the profane. They are just set apart, loaded with a different kind of meaning. Thus Durkheim made a presupposition that they are symbolic representations of something else. The characteristic of religion formulated by Durkheim is that it divides the world into the two domains of the sacred and the profane, seen as absolutely separate worlds:

"All known religious beliefs, whether simple or complex, present one common characteristic: they presuppose a classification of all the things, real and ideal, of which men think, into two classes or opposed groups, generally designated by two distinct terms which are translated enough by the words profane and sacred." 75

The opposition of the sacred and the profane is interpreted as the most basic human differentiation:

"This heterogeneity is sufficient to characterize this classification of things and to distinguish it from all others, because it is very particular; it is absolute. In all the history of human thought there exists no other example of two categories of things so profoundly differentiated or so radically opposed to one another. The traditional opposition of good and bad is nothing beside this: for the good and the bad are only two opposed species of the same class, namely morals, just as sickness and health are two different aspects of the same order of facts, life, while the sacred and the profane have always and everywhere been conceived by the human mind as two different classes, as two worlds between which there is nothing in common.",76

\footnotetext{
${ }^{73}$ Coleman and White, "Stretching the Sacred," 66.

${ }^{74}$ In his classic article Horace Miner provides an outsider's account on the tribe called Nacirema (hint: read it backwards). After realising that, in fact, Miner speaks about the odd tribe called the Americans, the reader is persuaded that it is possible to speak about contemporary culture in anthropological terms, and that there is not such a big difference between the so-called 'primitive' and industrialised societies. Therefore, treating archaic societies as inferior, or on the contrary, like relics of past's golden age of religiosity, are both limited Westcentric approaches. (Horace Miner, "Body Ritual among the Nacirema," American Anthropologist 58, no. 3 (1956), 503-507.)

${ }^{75}$ Durkheim, The Elementary Forms of Religious Life, 36.

${ }^{76}$ Ibid., 38.
} 
In Durkheim's view, the sacred is far from being synonymous with the divine (not to mention that he primarily used the adjective, for example, 'sacred things'). Neither man nor nature for him is inherently sacred. The source of the sacred, the reason for dividing the world into two polarities must be somewhere else. The sacred is also relative because what is held sacred depends on the religious system. Broadly speaking, the Durkheimian paradigm can be defined anthropologically as "a category of world classification and ritual behaviour."77

The sacred and profane life cannot take place in the same space and time. Sacredness requires those special locations as well as special times to be set aside for religious purposes. From analysing totemic religion Durkheim came to the conclusion that the sacred is society itself: "From the analysis to which we have been giving our attention, it is evident that it expresses and symbolises two different sorts of things. In the first place, it is the outward and visible form of what we have called the totemic principle or god. But it is also the symbol of the determined society called the clan."78 The god of the clan, the totemic principle, is thus the clan itself, represented in the image of an animal or plant, which serves the clan as the totem. The totemic emblem is like the 'visible body of god'. The sacred things are not sacred internally per se; they become so through human behaviour, certain rituals, 'setting apart'. The rituals, gatherings of people, common actions, and feasts are organised in order to strengthen the collective spirit and the unity of society, enabling them to feel their transformation and to renew their meaning. Here is how Durkheim describes the manifestation of society as the sacred principle in the modern age:

"This aptitude of society for setting itself up as a god or for creating gods was never more apparent than during the first years of the French Revolution. At this time, in fact, under the influence of the general enthusiasm, things purely laical by nature were transformed by public opinion into sacred things: these were Fatherland, Liberty, Revolution. A religion tended to be established which had its dogmas, symbols, altars and feasts." ${ }^{, 79}$

Thus, according to Durkheim, the sacred is created either by the community, or by society. In any case he holds the notion that this process of the sacred's creation and the necessity of having the sacred is a universal feature for all human cultures - a notion which

\footnotetext{
${ }^{77}$ Paden, "Before 'The Sacred' Became Theological," 70.

${ }^{78}$ Durkheim, The Elementary Forms of Religious Life, 206.

${ }^{79}$ Ibid., 214.
} 
will be criticised further. In other words, "there can be no society without the sacred, since the sacred is society's idealised vision of itself." 80

The sacred reality reflects social reality. Indeed, the opinion that Durkheim equated the sacred (god) with society is widely spread and, in the words of W. Watts Miller, oversimplifies Durkheim's original idea. As he argues further, Durkheim also believed that the sacred's modern centre is the human being, thus insisting on a certain switch from a god to a human. ${ }^{81}$ Modern society moved its centre of interest from a god to a human. Therefore, this society, according to Miller, is transcendent in relation to the individual. However, the question remains: with what did Durkheim intend to replace god - man or society? Miller gives an elegant answer to this by choosing the version "both": "In traditional worlds, god is at once the source and the centre of the sacred. In the modern world, society is the source of the sacred while man is the centre of the sacred." 82

Thomas A. Idinopulous goes even further arguing that Durkheim's sacred transcends society as an independent value, with its own meaning:

"The sacred comes forth in The Elementary Forms as an utterly unique force in society, the force to organize, morally judge, and give emotionally charged meaning to society. In that regard the sacred seems indeed to stand above the society as a transcendent divine power. To be sure, the sacred is not God or a god in Durkheim's methodology. But his way of thinking about the sacred tends to suggest that he could not simply limit himself to the language of functionalism ('setting things apart'). The sacred began to acquire the status of a metaphysical entity." 83

He also notices the ambivalence of Durkheim's thinking and claims that the sacred seems to function as an innate religious power that waits for a social context in which to express itself. To prove this argument he uses the following quote from Durkheim: "There is something in man which holds profane things at a distance and which possesses a religious power; in other words, the human organism conceals within its depths a sacred principle, which visibly comes to the surface in certain determined cases." 84

\footnotetext{
${ }^{80}$ Coleman and White, "Stretching the Sacred," 68.

${ }^{81}$ William Watts Miller, "Secularism and the Sacred: Is There Really Something Called 'Secular Religion'?” In Reappraising Durkheim for the Study and Teaching of Religion Today, ed. Thomas A. Idinopulos and Brian C. Wilson (Leiden; Boston: Brill, 2002), 28.

${ }^{82}$ William Watts Miller, "Durkheim, Kant, the Immortal Soul and God," in On Durkheim's Elementary Forms of Religious Life, ed. N. J. Allen, W. S. F. Pickering, and William Watts-Miller (London; New York: Routledge, 1998), 75.

83 Thomas A. Idinopulos, "The Strengths and Weaknesses of Durkheim's Methodology for the Study and Teaching of Religion," in Reappraising Durkheim for the Study and Teaching of Religion Today, ed. Thomas A. Idinopulos and Brian C. Wilson (Leiden; Boston: Brill, 2002), 12.

84 Ibid.
} 


\subsubsection{Critical Accounts}

In summary, despite the denial that religion is an 'innate given', Durkheim is still subject to similar criticisms as religionists. Despite the division of the two 'camps', both are problematic in a similar way. Both camps claim that the sacred is universal for all human societies and individuals, and both fill this notion with a transcendent, other-worldly meaning. Their concept of the sacred could be applicable only in the Judaeo-Christian context. Issues of value and meaning for non-religious people or people from other religious traditions are omitted implicitly or explicitly. Both camps also have in mind a certain romantic image that 'primitive' societies hold a special relation to god and the sacred. This can sound theologically attractive, but there is no empirical evidence for such claims. They state that what was true for these archaic social structures is the purest form of the phenomenon, which has been more dimly reflected as time goes on. Although theologically attractive, this statement remains empirically and logically unproven. Both the transcendent version and the Durkheimian socially-binding version do not fully cover the plurality of contemporary society and both are reductionist in the different senses.

William E. Paden also notes that the term of metaphysical reduction can be applied both to Eliade's and sociological versions. As he puts it, neither the former nor the latter could "face the data of sacrality without an act of metaphysical reduction." 85 Paden also asserts that the sacred is not a uniquely religious category, although obviously its religious meanings are better known. ${ }^{86}$ Hence he comes up to the previously mentioned idea of the middle path of the sacred. The concept of the sacred thus would not be reduced sociologically or theologically. ${ }^{87}$ It would be analysed without any metaphysical referent, without any criterions of 'righteousness':

"Sacredness would not be reduced to a single phenomenology of otherness or taboo, but would be examined for the many ways, subtle or otherwise, that it is constituted in human behaviour. For example, it is not only numen, forceful to the subject, but sacer, set apart by the subject as inviolate. It appears not only as 'the extraordinary' but as the integrity and transformation of boundaries, the monitoring of the boundaries of culturally and religiously constituted profaneness." 88

\footnotetext{
${ }^{85}$ Paden, "Before 'The Sacred' Became Theological," 76.

${ }^{86}$ Anttonen, "Sacred," 274.

${ }^{87}$ Paden, "Before 'The Sacred' Became Theological," 77.

${ }^{88}$ Ibid.
} 
Anttonen also claims that it is possible to have the sacred as a useful methodological tool when "it is theorized at the border between the cognitive and the cultural." 89 His suggested, as well as other possible definitions are discussed in the next section.

\subsection{The Contemporary Sacred}

Almost 100 years have passed since the time when Rudolf Otto warned those who had no religious experiences not to read his book further since he thought that only insiders can speak of religion. We no longer require a tradition steeped in religious belief to conceptualise the sacred. This concept was re-examined by a number of contemporary scholars, who regarded it as a broader notion applicable outside the field of religion.

However, today in scholarly works and beyond, the sacred is often used uncritically, synonymously with other terms such as 'spiritual', 'religious', 'divine', and 'mystical'. ${ }^{90}$ It is also used when speaking about the so-called pop-culture spirituality. ${ }^{91}$ The authors usually do not provide a frame of reference for their use of this term or understand it only through the Judaeo-Christian context. ${ }^{92}$ The main problem is that although the sacred was separated from religion, it was done so without critical accountability and rather subjectively. Hence it became individualised and potentially meaningless.

Terence Thomas once jokingly admitted that he prefers reading scholarly works in the study of the $19^{\text {th }}$ century religion because of the absence of the term 'the sacred':

\footnotetext{
${ }^{89}$ Anttonen, "Sacred," 278.

${ }^{90}$ Accordingly in MySpace to Sacred Space: God for a New Generation, the sacred in the postmodern sense is said to suggest a connection to god, community, and intentionally recognised time and space. When people experience the sacred, they "awaken the human senses that remind us we are alive. We enter the sacred space, longing to be moved - called - not by high production values and technological gimmickry, but by the beauty and grace of the God of all creation." (Christian Piatt and Amy Piatt, MySpace to Sacred Space: God for a New Generation (St. Louis, MO.: Chalice Press, 2007), 3-4.) Thus, the imprint of Christian theology can be seen on the notion of the sacred despite the usage of postmodern terms.

${ }^{91}$ Em McAvan notes that the postmodern sacred is, in basic terms, pop-culture spirituality. (Em McAvan, The Postmodern Sacred: Popular Culture Spirituality in the Genres of Science Fiction, Fantasy and Fantastic Horror (PhD diss., Murdoch University, 2007). In other words, it is spiritual pop-culture, born in-between traditional religions and New Age inspired spirituality.

92 The authors who analyse literature often do not provide the definition as of what they call the sacred in their works. If presented, that definition can sound similar to the one by Daniel Tobin, who in the Eliadean fashion claims that by saying "the sacred" he means "a revelation of the numinous often encountered in the religions and myths of various cultures as a hierophany." (Daniel Tobin, Passage to the Center: Imagination and the Sacred in the Poetry of Seamus Heaney (Kentucky: University Press of Kentucky, 1999), 4.)
} 
"If I were a cynic, which I am not, I would say that the body of the contemporary study of religions is suffering from a rash called 'the sacred', a rash that gives me a sort of itch and it is an itch that I cannot refrain from scratching. In a time when many people are wont to lament the state of the world they inhibit, especially their little part of it, and the cry frequently goes up, 'Nothing is sacred any more,' I wish to say 'Wrong, everything is 'sacred' these days'.",93

What Thomas has in mind is a definite strong tendency in religious studies to treat the sacred as a term that defines religion. ${ }^{94}$ Moreover, he claims that such a universalisation of the sacred, that is, defining religion in terms of the sacred is "fundamentally theological whether directly theological, as in the work of Tillich, or comparative theological, as in Eliade's work, and should be recognized as such in the study of religions." 95 This, together with the sacred as a tool to define religion and religious phenomena is, in his opinion, not suitable for academic work. ${ }^{96}$ In such a stretching of the term, the sacred reflects its understanding beyond the traditional religions. ${ }^{97}$ However, it also reflects a certain methodological carelessness, because in such a case people might claim that something or someone is sacred only judging by their 'experience':

"We might include amongst these altered states of consciousness such as ecstasy, a special way of knowing or hyper-consciousness, visions and auditions, the experience of paranormal or occult phenomena, or the experience of a connection with the earth, for example, as in 'nature mysticism'.,"98

Such a statement not only does not provide us with enough clarity on the sacred, but also narrows the concept down to the 'experience'. Such a theoretical stretching of the sacred beyond religious borders was made possible through the analysis of this concept within the social sciences and Emile Durkheim's works in particular.

Many contemporary scholars, including Veikko Anttonen, William E. Paden, and Gordon Lynch, have spoken about the reformulation of the concept. This chapter already mentioned the middle path of the sacred, suggested by Paden. Meanwhile, Anttonen proposes a possible definition of the sacred as a "relational category of thought and action, which becomes actualized in specific value-loaded situations when a change in the contextually

\footnotetext{
93 Thomas, “'The Sacred' as a Viable Concept," 47.

94 Ibid., 52.

95 Ibid., 59.

${ }^{96}$ Further Thomas declares that using the sacred as a generic term for religion is "a subtle form of theological imperialism exercised by Western scholars on the Eastern and archaic Others." (Ibid., 63.)

${ }^{97}$ Coleman and White, "Stretching the Sacred," 65.

${ }^{98}$ Ibid.
} 
interpreted boundaries of temporal, territorial or corporeal categories takes place." 99 Here, the religious worlds are no longer held as a privileged place for the emergence of the sacred. Gordon Lynch provides yet another, more practical and applicable definition, which states that:

"The sacred is an object defined by a particular quality of human thought, feeling and behaviour in which it is regarded as a grounding or ultimate source of power, identity, meaning and truth. This quality of human attention to the sacred object is constructed and mediated through particular social relations, and cultural practices and resources." $" 100$

For Lynch, religions are social and cultural systems which are oriented towards sacred objects. In this definition the sacred is not held as a universal, numinous phenomenon experienced privately, but it is instead placed in a social and cultural context. The sacred/profane binary is also left out, and the possibility of different sacred objects coexisting in the same cultural system is guaranteed.

Thus Lynch's definition is a good starting point for discussing the contemporary use of this notion. However, it also needs to be slightly revised. First, the temporal and dynamic aspect of the sacred should be emphasised. Other than presenting the sacred as transcendental and hence eternal - not subject to human will or time - this definition enables the changeability of this concept. The objects of the sacred, as well as human emotions, thoughts and behaviour are dynamic, temporary and can evolve or change. This is especially evident in the post-Soviet context that will be analysed in the subsequent chapters. However, in order to avoid essentialising, this research does not claim that every human being shares the need to have something that is sacred and that this need is itself permanent and unchangeable. The sacred is not a universal notion.

Secondly, the ambiguity of the sacred should be noted. The sacred can be experienced either positively as binding people, or experienced negatively as entrapping them and limiting their freedom. ${ }^{101}$

\footnotetext{
${ }^{99}$ Anttonen, "Sacred," 278.

${ }^{100}$ Gordon Lynch, "What is this 'Religion' in the Study of Religion and Popular Culture?" in Between Sacred and Profane: Researching Religion and Popular Culture, ed. Gordon Lynch (London; New York: I. B. Tauris, 2007), 138

101 The most obvious example being the 'monetary sacred' in Pelevin's prose, which will be thoroughly discussed in the literary chapters.
} 
Thirdly, although Lynch uses the word 'object' to define the sacred, and although this word has a broad meaning, it also provides unnecessary associations with materiality only and narrows down the concept.

The sacred thus presents itself as a special quality in the systems of meaning, both collective and individual, as a psychosocial need. This human's need for meaning, expressed through certain bodily behaviours, complements the need for unity, integrity, and monitoring the boundaries in society.

To sum up, what has been added to Lynch's definition, a slightly redefined one can be presented which will be used in this dissertation:

The sacred is an object, an idea or entity defined by a particular quality of human thought, feeling and behaviour in which it is regarded as an ultimate source of power, identity, meaning and truth. This relationship between a human and that what is considered sacred is subject to dynamism, changeability and temporality, and can be experienced as either a positive or negative category. It is constructed and mediated through particular social relations, cultural practices and resources, and complements the need for unity and integrity in society. ${ }^{102}$

This revised concept takes into account the present epoch's needs to constantly reframe its values and beliefs, which vary considerably from the intellectual context of the $19^{\text {th }}$ and the early $20^{\text {th }}$ century. In this century, scholars regarded the sacred as an eternal, transcendental phenomenon, which could not be described empirically. Such a concept is itself difficult to integrate into the postmodern thought. A refusal to regard religious worlds as a privileged sphere for the appearance of the sacred enables us to analyse different sacred objects from various perspectives in the same cultural system.

The renewed definition of the sacred is especially important today because of the number of people who do not associate themselves with any religious denomination. These people are currently excluded from the discourse of the sacred if it is associated with only religious meanings. However, the void where religion used to be can be filled with other kinds of 'sacredness' - that of national traditions, political ideologies, or personal mythology, and of such general categories as love or freedom. Veikko Anttonen argues that people participate in sacred-making activities according to paradigms given by the belief systems to which they are committed, whether they be religious, national or ideological. These paradigms may have their origins in the history of religion, national tradition, political

\footnotetext{
${ }^{102}$ Literary analysis will show in which situations the search for the objects, ideas and entities that could be considered to be sacred can be actualised. I will discuss it in the fourth chapter and the subsequent literary chapters.
} 
ideology, or may just be born from the diversity of the contemporary world-view and of the personal history. Thus a refusal to regard religious worlds as a privileged sphere for the appearance of the sacred enables us to analyse different sacred objects in the post-Soviet milieu, and particularly in our case study of its literature. As mentioned, the post-Soviet period was chosen as an ultimate example of a seemingly secular society as well as literature. Post-Soviet literature, namely, Pelevin's prose, will present us an opportunity to see how this modified concept of the sacred can be applied.

\subsection{Conclusions}

This chapter attempted to provide an overview on the history of the sacred, and to provide a definition suitable for contemporary use. To sum up: in this dissertation three 'NOTs' will be applied when defining the sacred. First, I will use this concept as not necessarily being directly connected to the religious worlds. Secondly, I will not use it as a universal term for overriding different cultures. Lastly, this concept will not be regarded as a permanent or unchangeable notion outside of history. This research will also argue that the dichotomy of the sacred and the profane creates a false distinction between the everyday 'profane' life and the sphere of transcendence and can also presuppose certain value judgements. This distinction is no longer suitable for the contemporary scholarship (and was never appropriate as a universal claim) and does not cover all the varieties of the sacred in society. This sacred-profane duality can at most be accepted as referring to only one type of religious conscience. Hence it cannot be applied to the other religious systems. ${ }^{103}$ This duality could also be regarded as supposing certain value criteria and thus should not be applied.

Consequently, the sacred will be regarded as a relative and temporary phenomenon, which is constructed through certain cultural practices and traditions and first and foremost helps us disclose the concepts of meaning, identity and community in contemporary society through the individual reactions, perceptions and behaviour directed to the objects which are perceived as sacred. This model, based on Gordon Lynch's definition, will serve as a tool to discuss the post-Soviet sacred - a notion that has hardly been discussed before. Being an exterior as well as an interior phenomenon, the sacred can appear as a psychosocial need,

\footnotetext{
${ }^{103}$ Further discussions on the inaccuracy of treating the sacred/profane distinction as universal: Lynch, "What is this 'Religion' in the Study of Religion and Popular Culture?" 135-137; Coleman and White, "Stretching the Sacred," $72-73$.
} 
where the quest for meaning in a human's soul, expressed through certain bodily behaviours, complements the quest for unity, integrity, and the monitoring of the boundaries in society.

The second chapter will continue with the anthropological tools that will later, in the literary chapters, help us talk about the sacred in post-Soviet literature. The third chapter will follow with an overview of the post-Soviet condition. If the concept of the sacred is regarded as non-universal and non-eternal, it can be claimed then that after the break-up of the Soviet Union, that which was held sacred experienced a huge change. Namely, what took place in the post-Soviet era was a radical rethinking of sacrality. Therefore, the third chapter will attempt to describe that change and define the new contours of the post-Soviet sacred. 


\section{Chapter 2: The Sacred as Literary Tool}

This chapter provides a methodological background on the sacred in post-Soviet literature and organises the main concepts of this research. This dissertation holds that the sacred can manifest itself in conventional and non-conventional ways. Examples of conventional manifestations include rituals that help disclose and embody one's relation with the sacred (initiation and sacrifice in particular), also the notions of sacred space, time, and persons. The concept of liminality, which is of the utmost importance in this research, will also be discussed in this context as primarily a significant part of ritual. However, this notion is broader than only as a part of ritual. ${ }^{1}$ The non-conventional manifestations of the sacred can be explored through the analysis of the use of sacred substances. It can also be named as alternative spiritualities or, more broadly, modes of escape. The sixth chapter explores how psychedelic substances can be used in the search for the sacred. It shows that sacred substances are not the only mode of escape, and discusses two others; namely, alcohol and immersing in TV-mediated reality. Closely associated with the categories of sacred space and escape is the notion of the ultimate escape, or liberation, which is thoroughly discussed in the seventh chapter.

Regardless of this classification, it should be noted that all categories are also closely intertwined. Therefore, the example of the initiation process in the fifth chapter can also be discussed in the context of alternative spiritualities in the sixth chapter.

As mentioned, this chapter presents a theoretical framework. The practical applicability and examples from Victor Pelevin's prose will be analysed in the literary chapters. $^{2}$ This chapter starts with the conventional expressions of the sacred and then follows with the non-conventional ones.

\footnotetext{
${ }^{1}$ Liminality is discussed in section 2.6. The applicability of this concept is discussed in the fourth chapter, section 4.5.

${ }^{2}$ Examples from the literary texts here are not provided purposely in order to avoid jumping ahead. It is barely useful to talk about the post-Soviet sacred without defining the post-Soviet condition first. This will be done in the third chapter. The same can be said about the notions of emptiness and escape in Pelevin's prose - these need more contextualisation, thus they will be discussed in the subsequent chapters.
} 


\subsection{Sacred Space, Sacred Persons}

The notions of sacred space, time, ${ }^{3}$ and persons are important for the further analysis of post-Soviet literature, as they clearly demonstrate the criteria for 'sacredness'. However, these notions can also be misleading, pointing out to some religious or spiritual categories that are not considered exclusive in this research. Later on this research will reveal that postSoviet literature can present different modes of sacrality.

Without going into an overly detailed overview of the traditional notion of the sacred space, it should be noted that a sacred place is considered to be first of all "a defined place, a space distinguished from other spaces." practices that are either practised at that place or directed towards that place. These can be places constructed for religious purposes (such as temples) as well as places that are religiously interpreted (such as mountains). ${ }^{5}$ These can be both physical spaces (the outer geography) and the inner geography (the body in a Tantric yoga). In short, a sacred place comes into being when it is interpreted as a sacred place.

Three roles of sacred space are distinguished: "First, sacred space is a means of communication with the gods and about the gods. Second, it is a place of divine power. And third, it serves as a visible icon of the world and thereby imparts a form to it and an organization to its inhabitants." places can be limited to this classification. These chapters also will explore the link between the sacred space and the liminal space - the comparison similar to that of the so-called sacred person and a liminal person. In general, the link between the liminal and the sacred will be thoroughly analysed. Moreover, the literary chapters will show that the sacred places in Pelevin's prose can go beyond the classical notion, which is deeply embedded in the JudaeoChristian tradition.

Thus the working definition of the sacred space (suitable for the purposes of this research) states that it is a space where a person's search for the sacred is actualised, or where the source of what is considered to be sacred is found. This space is subject to temporality and changeability.

\footnotetext{
${ }^{3}$ (Sacred) time does not have an importance similar to the importance of the (sacred) space in Pelevin's prose and therefore is not further analysed here.

${ }^{4}$ Joel P. Brereton, in Encyclopaedia of Religion, $2^{\text {nd }}$ ed., s. v. "Sacred Space."

${ }^{5}$ Ibid.

${ }^{6}$ Ibid.
} 
Accordingly, the definition of the sacred person could also be revised. Generally prophets, sages, saints, and spiritual masters are considered to be sacred persons. They are the ones who have experienced unitary consciousness and can lead others on the spiritual path, as they have already attained sacred knowledge. As this research avoids privileging religious meanings, a sacred person will be considered someone who has achieved that which constitutes the sacred for this person. ${ }^{7}$ As mentioned above, these persons can help others in their quest for the sacred (resembling the notion of Bodhisattva in Mahayana Buddhist tradition). Thus neither the sacred space, nor the sacred person, is separated from everyday reality. The sacred, being not necessarily a transcendent category, can be perceived and experienced here and now. The next sections present a conventional way people use to connect with the sacred, that is, the notion of ritual.

\subsection{The Notion of Ritual}

It was only in the $19^{\text {th }}$ century that a certain type of human activity started being defined with the word 'ritual'. Nowadays ritual studies have evolved into an interdisciplinary scholarship across religious studies, anthropology, media and performance studies. However, as the anthropologist Catherine M. Bell notes, the notion of ritual also needs critical rethinking. ${ }^{8}$ She warns that "the study of ritual arose in an age of unbounded confidence in its ability to explain everything fully and scientifically, and the construction of ritual as a category is part of this world-view." ${ }^{9}$ Ritual remains one of the most difficult concepts to define. Needless to say that the analysis of ritual is subject to the same flaws as in the case of the sacred; namely, universalising this concept, applying it uncritically, holding it as only a category applicable to talking about religious behaviour or, on the contrary, choosing too broad a meaning, which includes the cases that have only a partial resemblance to ritual. Moreover, this concept itself can be understood as a Western, scholarly construct, given the

\footnotetext{
${ }^{7}$ That is, the ultimate source of power, identity, meaning and truth, according to the definition of this research.

${ }^{8}$ Catherine M. Bell's work Ritual Theory, Ritual Practice is considered a seminal work in the study of ritual. Another book, Ritual: Perspectives and Dimensions, offers an overview for ritual practice and its study. Discussing the most influential theories of ritual, Bell suggests a critical rethinking of its understanding.

${ }^{9}$ Catherine M. Bell, Ritual: Perspectives and Dimensions (New York: Oxford University Press, 1997), 21. In this work she also provides an extensive overview of the theories that have attempted to analyse ritual, its function and meaning, from the earliest, including William Robertson Smith and James George Frazer, to phenomenologists of religion, such as Gerardus van der Leeuw and Mircea Eliade, and to Freudian psychoanalytical approach and recent theorists.
} 
fact that many languages simply have no such word. Ritual was an outsider's term, defining certain types of activities in tribal societies. ${ }^{10}$

However, the aim of this research is not to redefine the term 'ritual'. Here it is merely a tool to speak about the sacred. Therefore, this chapter does not provide a historical overview of the development of this term. It also does not deal with ritual theories which abound. ${ }^{11}$ Instead, I argue that as well as with the concept of the sacred, ritual should not be reduced to only a religious understanding. ${ }^{12}$ Also, rituals are not to be treated as universal and unchangeable. Regarding ritual as an unchangeable and universal structure would make it difficult, if not impossible, to analyse the contemporary modes of ritual behaviour due to the huge changes of ritual behaviour.

Ritual is not an intrinsically special action. What makes it special is the intention and context, in comparison to other actions. Thus ritual can be created and re-created, being regarded as a temporal and intentional action:

"Formalism or repetition or traditionalism are not intrinsic qualities of ritual practices, but common strategies for producing acts that can dominate their context in important and useful ways. On this basis, a universal characterization of ritualization may be impossible; it may be describable only in general terms since even the most widespread strategies could mean different things in different cultural contexts."13

Although Bell's theory unavoidably also falls into the trap of universalising and essentialising, it nevertheless can serve as a tool in this research. Instead of narrowing ritual down to a sole definition, Bell attempts to show the multiplicity of the possible interpretations: "I $d o$ intend to modify the term ritual to function as something other than a 'global construct' or 'a key to culture',"14 she declares, emphasising the need not to simply change the existing terms, but to rethink ritual as having less generality, and less universality. ${ }^{15}$ Ritual can be defined in various ways: starting from the broadest, that ritual is

\footnotetext{
${ }^{10}$ Ronald L. Grimes, "Ritual," in Guide to the Study of Religion, ed. Willi Braun and Russell T. McCutcheon (London; New York: Cassell, 2000), 261.

${ }^{11}$ A number of ritual theorists have provided an extensive overview on the history and theory of ritual, for example, Catherine M. Bell, Ronald L. Grimes, and Jonathan Z. Smith.

${ }^{12}$ Grimes, "Ritual," 260.

${ }^{13}$ Catherine M. Bell, in Encyclopaedia of Religion, $2^{\text {nd }}$ ed., s. v. "Ritual [Further Considerations]."

${ }^{14}$ Catherine M. Bell, Ritual Theory, Ritual Practice (New York: Oxford University Press, 1992), 7.

${ }^{15}$ Some theorists tend to distinguish ritual from ceremony. According to them, ceremony is less religious or less important, in other words, a more neutral category. (Grimes, "Ritual," 260.) However, in this thesis the word ritual is sufficiently neutral and bears no religious connotations, so there is no need to replace ritual with ceremony.
} 
"culturally defined sets of behaviour," to a more specific, "traditional, prescribed communication with the sacred."16

Bell's theory regards ritual not as a certain privileged and structurally distinct activity but as a particular type of action amongst others, in the context of cultural actions. In this sense her theory contradicts the previous theoretical models, such as those of Arnold van Gennep, Emile Durkheim, and Mircea Eliade, all of whom regarded ritual as a fundamentally different sort of social event, thus assuming that ritual must be absolutely different from profane actions, therefore assigning sacred qualities to ritual. ${ }^{17}$

The dichotomy of rituals (secular/profane versus sacred) is neither informative nor helpful, and can even be misleading in the context of this thesis. For this research, ritual implies a certain mode of acting directed towards what is considered as sacred. There are no privileged forms of ritual. Any activity can be ritualised as long as it helps connect with the sacred.

Everything can have a potential significance, everything can become ritual, when it takes place in the sacred - set apart - space, notes Jonathan Z. Smith. ${ }^{18}$ Ritual has a tendency to be routinised. An ordinary thing can become 'sacred' by simply being in a certain place, at a certain time. Once again the relativity of the sacred should be emphasised. "There is nothing that is sacred in itself," says Smith accordingly, "only things sacred in relation." ${ }^{19} \mathrm{He}$ also discusses the inevitability to distinguish 'meaningful' actions, which have a potential to be called rituals, from trivial repetitions. He warns that "if everything signifies, the result will be either insanity or banality." 20 Smith also attempts to provide the following definition of ritual:

"Among other things, ritual represents the creation of a controlled environment where the variables (i.e. the accidents) of ordinary life may be displaced precisely because they are felt to be so overwhelmingly present and powerful. Ritual is a means of performing the way things ought to be in conscious tension to the way things are in such a way that this ritualized perfection is recollected in the ordinary, uncontrolled, course of things.",21

\footnotetext{
${ }^{16}$ Grimes, "Ritual," 261.

${ }^{17}$ Encyclopaedia of Religion, $2^{\text {nd }}$ ed., s. v. "Ritual [Further Considerations]."

${ }^{18}$ Jonathan Z. Smith, Imagining Religion: From Babylon to Jonestown (Chicago: University of Chicago Press, 1982), 53.

19 Ibid., 55.

${ }^{20}$ Ibid., 56.

${ }^{21}$ Ibid., 63.
} 
Ritual is a potential action, an 'ideal' creation of the world, performed knowing that in reality, it cannot be actualised. Thus one of the possible attempts to define ritual can be a need to get in touch with the sacred realm though knowing that the real merging with the sacred is not possible. As a specific kind of action, ritual could also be defined by such characteristics as formal, stylised, symbolic, non-technological, having the collective dimension, and repetitive. ${ }^{22}$ Contrary to the widely spread notion that ritual is meant to transform the participants, it can be said that such an idea looks "increasingly dated, an artefact of the 1960s and 1970s." 23 To put it another way, it may or may not transform the participants - the outcome is different in each specific case. As Ronald L. Grimes states, "in an initiation, for instance, transformation may occur in self-perception, relationships with cosmic or divine powers, access to power, knowledge or goods, kin- and other social relationships. We need to ask, what are the 'before' and 'after' states, and how do they compare? How significant is the change? Who is changed by the rite of passage?"24

\subsection{The Typology of Ritual}

The first chapter came to the conclusion that neither the sacred nor the sacred/profane distinction could be held universal. This is why Emile Durkheim's ritual classification should be considered with caution. ${ }^{25}$ Durkheim divided ritual behaviour into positive and negative rites (positive rites were meant to help humans contact the sacred, and negative rites separated them from the sacred by setting rules, restrictions, and taboos), and this classification is based on considering the sacred and the profane as universal categories. That is why Victor Turner divided rituals into life-crisis rituals and rituals of affliction. Ronald Grimes presented the following categories: rites of passage, marriage rites, funerary rites, festivals, pilgrimage, purification, civil ceremonies, rituals of exchange, sacrifice, worship, magic, healing rites, interaction rites, meditation rites, rites of inversion, and ritual drama. ${ }^{26}$

\footnotetext{
${ }^{22}$ Grimes, "Ritual," 262; Sally Falk Moore and Barbara G. Myerhoff, Secular Ritual (Assen: Van Gorcum, 1977), 7.

${ }^{23}$ Grimes, "Ritual," 268.

${ }^{24}$ Ibid., 267.

${ }^{25}$ Another distinction, according to Catherine M. Bell, is between instrumental and expressive rituals, the former attempting to make something happen, the latter simply expressing certain ideas or feelings. Yet this distinction would support the notion that 'instrumental', or magical rituals are meant to manipulate supernatural powers, and that expressive ones are a "purer form of disinterested worship." (Bell, Ritual: Perspectives and Dimensions, 93.)

${ }^{26}$ Ronald L. Grimes, "Sources for the Study of Ritual," Religious Studies Review 10, no. 2 (1984): 134.
} 
However, such an extended classification is not necessary for the purposes of this research. This chapter uses the following classification by Catherine M. Bell, who suggested dividing the ritual activity into six categories, where it is held as primarily communal, traditional and based on the belief in some divine beings: rites of passage ('life-cycle' or 'life-crisis' rites; that is, birth, coming of age, marriage, and death); calendrical and commemorative rites; rites of exchange and communion; rites of affliction; rites of feasting, fasting, and festivals; and political rituals. ${ }^{27}$ Bell also adds that this list should not be regarded as definitive. Some rituals can be placed in more than one category, and some others would need additional categories.

Several changes would help to simplify this classification for the analysis of ritual in contemporary literature. First, rites of affliction can include rites of feasting, fasting, and festivals, as will be noted later. Secondly, there is no necessity to exclude a separate category of political rituals. Ritual would be understood as rooted in a belief of something that a group of people considers 'sacred'. Thus the political ideology for a certain group of people is also sacred. Having this particular category implies that political rituals are secular and that the other forms of ritual are more connected with religious category, but rituals should not necessarily be connected with the divine.

Having slightly adjusted Bell's scheme, a following typology of ritual can be presented. This classification will help explore ritualistic behaviour in post-Soviet literature and analyse how ritual helps in connecting with what is perceived as sacred in the post-Soviet milieu.

1. Rites of passage. In a traditional sense this is birth, the coming of age, marriage and death, as previously mentioned. But in this case the most important factor entering into such a rite of passage is not the biological change of the human but rather the socio-cultural order of their community. Physical birth does not necessarily mean that the new member is already accepted by the community. In other words, ritual passage consists of the 'before'- a period of learning that is 'betwixt and between', and the 'after' - when the transformation of the person is complete. ${ }^{28}$ The initiation rites, discussed in section 2.5 , belong to this type.

2. Calendrical rites. These define the passage of time, creating the cycle of days and years, marking, for example, celebrations of the New Year, Easter, etc. They can be divided into seasonal and commemorative celebrations and define the order of nature.

\footnotetext{
${ }^{27}$ Bell, Ritual: Perspectives and Dimensions, 94.

28 Arnold Van Gennep's threefold scheme, consisting of separation, a liminal phase (transition), and a reincorporation (more in Arnold van Gennep, The Rites of Passage (London: Routledge \& Kegan Paul, 1960).
} 
3. Rites of exchange and communion. These are offerings to gods (or, to be precise, the sacred), while expecting to get something in return. These can be such innocent offerings as food or flowers or, according to Bell, this type also includes sacrifice. Offerings include not only material things such as food, incense, and flowers, but also dances, songs and even theatre productions. ${ }^{29}$

4. Rites of affliction. This is a type of ritual which attempts "to rectify a state of affairs that has been disturbed or disordered; they heal, exorcise, protect, and purify." ${ }^{30}$ Examples can be associated with the notions of sin and karma, the 'pollution' of menstruation, childbearing, and death. Alhough they appear to be morally neutral, they still require ritual purification. The understanding of such rituals is relative, dependent on the given cultural environment. Purification here carries a special significance. This purification can be either from demonic possession, or from disease, sins, karmic consequences, etc. However, this type of ritual is definitely more complex, and it is difficult, if not impossible, to generalise.

5. Feasting, fasting, and festivals. These can serve as a subsection of the previous one, except that feasting and fasting are supposed to be more communal actions: "Shared participation in a food feast is a common ritual means for defining and reaffirming the full extent of the human and cosmic community." 31

The next section provides a more extensive overview of the types of ritual that will be further discussed in the fifth chapter, namely, initiation and sacrifice.

\subsection{Sacrifice}

The word 'sacrifice' derives from the Latin sacer facere - to make holy. Found in most known religions, sacrifice is primarily associated with the religious purposes of creating a union between the divine and human worlds, when the receiver is a supernatural being or force. Amongst the most common definitions of sacrifice is that it "carries the connotation of the religious act in the highest, or fullest sense; it can also be understood as the act of sanctifying or consecrating an object." 32 Thus the essential element in defining sacrifice becomes the receiver, understood as a supernatural being. However, this research would

\footnotetext{
${ }^{29}$ Bell, Ritual: Perspectives and Dimensions, 111.

${ }^{30}$ Ibid., 115.

${ }^{31}$ Ibid., 123.

${ }^{32}$ Encyclopaedia of Religion, $2^{\text {nd }}$ ed., s. v. "Sacrifice."
} 
argue that sacrifice, like the concept of the sacred, can be regarded as having not only religious connotations. The anthropologist Parker Shipton also emphasises that nowadays sacrifice is more than just a religious term:

"Sacrifice is a guarded privilege and a way to seek or exercise power and privilege (and therefore political), a dramatic performance (and therefore aesthetic), a way of raising hope, salving conscience, or perhaps projecting or transferring aspects of the self (and therefore psychological). It is often, too, a way of joining people together, and in doing so potentially marking them off from others (hence sociological).,"33

Being such a complex phenomenon, sacrifice has to be considered having in mind these possible viewpoints.

Most early scholars of religion, including William Robertson Smith and James George Frazer, concentrated on sacrifice, making it a key ritual in their works. English anthropologist Edward Tylor understood sacrifice as a gift made to a deity, a tribute. ${ }^{34}$ An important contribution to the understanding of sacrifice was made by Henri Hubert and Marcel Mauss, who distinguished sacrifice from the other forms of offerings, observing that in the case of sacrifice the offerings are consecrated. ${ }^{35}$ For Hubert and Mauss, sacrifice was a special form of ritual, involving the union with the sacred, which balances the disequilibrium between the sacred and the profane:

"An essentially profane offering is made sacred - consecrated, in effect - in order to act as the means of communication and communion between the sacred and profane worlds. ... The sacrificial process functions to re-establish social equilibrium after it has been upset." ${ }^{, 36}$

According to René Girard, sacrifice is an act of violence performed on a surrogate victim - this is what Girard calls the "surrogate victim mechanism". That victim can later be hailed as a bearer of peace, a sacred figure. ${ }^{37}$ The so-called 'scapegoats' are used to save society and to prevent it from the following violence:

\footnotetext{
${ }^{33}$ Parker Shipton, "Blood, Fire, and Word: Luo, Christian, and Luo-Christian Sacrifice," in Ritual, ed. Pamela J. Stewart, Andrew Strathern (Farnham, Surrey, England; Burlington, VT: Ashgate Pub. Co., 2010), 478.

34 Jill Robbins, "Sacrifice," in Critical Terms for Religious Studies, edited by Mark C. Taylor (Chicago: University of Chicago Press, 1998), 288.

${ }^{35}$ Henri Hubert and Marcel Mauss, Sacrifice; Its Nature and Function (London: Cohen \& West, 1964).

${ }^{36}$ Bell, Ritual: Perspectives and Dimensions, 26.

${ }^{37}$ Lefebure, "Victims, Violence and the Sacred," 1226.
} 
"[T]he violence directed against the surrogate victim might well be radically generative in that, by putting an end to the vicious and destructive cycle of violence, it simultaneously initiates another and constructive cycle, that of the sacrificial rite which protects the community from that same violence and allows culture to flourish." 38

The sacred appears as violence directed at a sacrificial victim. The victim is sacred: it renews order and peace in the community. According to Girard, through the mechanism of violence and sacrifice the birth of religion can be explained. The sacred, he argues, arose out of sacrifice, which puts an end to the profane cruelty in society. If blame is not clearly concentrated on the victim, it may spread dangerously to everybody. ${ }^{39}$

Girard's theory of sacrifice can add an additional dimension to Bell's argument. Namely, that sacrifice not only reflects the complex relations of mutual interdependence between the human and the sacred, but also the social and cultural processes by which the community organises and understands itself. ${ }^{40}$ Bell also notes that although ritual theories tend to focus on the 'communion' with god, during the sacrificial process the offerer, the recipient, and the offering become one. This communion is most clearly expressed in the killing of an animal or a human. Then, the offering can become sacred itself (for example, the real presence of Jesus Christ in the sacralised bread and wine). However, this term itself derives from the Judaeo-Christian tradition and as such is not broadly applied in the other cultures. ${ }^{41}$ Bell also notes that sacrifice, more than any other ritual form, was considered universal. Indeed, forms of sacrifice, according to her, can be found in almost all societies, thus the definition of sacrifice should be very broad.

This research argues that the sacrifice's receiver must not necessarily be a supernatural being or force. Sacrifice can be performed for various purposes, related to what is considered sacred: either to praise, to give homage, to give thanks, to expiate guilt, or to supplicate. Sacrifice can thus be understood in various ways, for example, as a gift, a link connecting with the sacred, as magic, as the re-enactment of primordial events, as an anxiety reaction, and as a mechanism for diverting violence. ${ }^{42}$ Moreover:

\footnotetext{
${ }^{38}$ Girard, Violence and the Sacred, 93.

${ }^{39}$ Bandera, The Sacred Game, 23.

${ }^{40}$ Bell, Ritual: Perspectives and Dimensions, 109.

${ }^{41}$ Ibid., 113. To be precise, offering, according to Jan van Baal, is an act of presenting something to a supernatural being, and sacrifice involves ritual killing in the act of the presenting. (Encyclopaedia of Religion, $2^{\text {nd }}$ ed., s. v. "Sacrifice.") However, for this research the distinction between sacrifice and offering is not of the primary importance, hence only the term sacrifice is used.

${ }^{42}$ Encyclopaedia of Religion, $2^{\text {nd }}$ ed., s. v. "Sacrifice."
} 
"Sacrifice works to express what people cannot easily put into words, or to control that which cannot be controlled directly. Some feel it transports them into another state, bringing them nearer to divinity and each other. By communication through the death of the thing sacrificed, a sacrifice can represent an attempt to secure a piece of divine power, perfection, or favour, or to cleanse partakers of pollution: to procure the desired or get rid of the unwanted. Sacrifice can also represent time out of time: through its preparation, some feel, they enter a separate sphere, crossing a time horizon into a kind of black hole where the ordinary rules and sequences of living do not apply. Sacrifice, like other ritual, connects the present with the past and future, evoking what is does not directly denote or describe.",43

Being a particular type of ritual, sacrifice also experienced major changes. These changes include not only the type of sacrifice, but also changes in ritual or object sacrifice. Also crucial is the change of understanding sacrifice - it is not only a material object, but it can be a commitment to one's aims or ideas; not only external, but also internal phenomena. Such a broadening of the notion and such an emphasis on the interior attitude becomes necessary in the contemporary terrain. Sacrifice (and initiation, which is discussed in the next section) are to be treated as ambiguous, dynamic and changing. It can also help track that which can be considered sacred in this seemingly secular milieu. Analysing the concept of sacrifice in literary texts, the following questions should be asked: who offers sacrifice, who is the recipient, and what is offered as sacrifice? Contextualisation is also important, such as the time, space and conditions of the act of sacrifice. The fifth chapter demonstrates that the analysis of initiation and sacrifice in post-Soviet literature can help to further redefine these concepts.

\subsection{Initiation}

According to Barry Stephenson, the classical rites of passage theory was constructed on the following three pillars: the works of Mircea Eliade (namely, his Rites and Symbols of Initiation), Arnold van Gennep (The Rites of Passage), and Victor Turner (The Ritual Process: Structure and Anti-Structure). ${ }^{44}$ As he argues, initiation belongs to the 'canonical' big four, that is, rites of birth, initiation, weddings, and funerals. For Mircea Eliade, initiation is "a body of rites and oral teachings whose purpose is to produce a radical modification of

\footnotetext{
${ }^{43}$ Shipton, "Blood, Fire, and Word," 493.

${ }^{44}$ Encyclopaedia of Religion, $2^{\text {nd }}$ ed., s.v. "Rites of Passage: An Overview [Further Considerations]."
} 
the religious and social status of the person to be initiated." ${ }^{45}$ He identifies three types of initiation: transitory (from childhood to adolescence to adulthood), entering a secret society (most of them male), and the type of initiation that occurs with a mystical vocation (for example, the way of the shaman). ${ }^{46}$

Initiation, according to Catherine M. Bell, is a certain type of rite of passage. Together with Arnold van Gennep, she argues that the traditional rites of passage "provide the model for initiations into special groups whose membership is not closely tied to any formal stage of life." ${ }^{, 47}$ Initiation can signify merely an acceptance into a new community and the start of a new 'spiritual' stage of life. Bell also argues that:

"The logic of these rites creates symbolic stages and passages that redefine social and personal identity. For this reason, it is not surprising to find symbolic and experiential similarities in the initiation of neophytes into the $19^{\text {th }}$-century Chinese secret society known as the Triads, basic training at a U.S. Marines Corps boot camp, and the threeyear seminary program for new monks at a Zen monastery." 48

Bell is not making value differences between the so-called secular, or modern, and religious, or traditional initiatory processes, as in the classical rites of passage theory. That said, as with the classical theory of the sacred, the classical rites of passage theory is also subject to criticism. First, as Barry Stephenson notes, it uses rites of initiation (specifically male initiation) as the paradigm for all passage. ${ }^{49}$ Even though male initiation rites in many cultures consist of the three phases, not necessarily all rites of passage do. Such a tripartite structure can be influenced by the Western intellectual tradition.

Secondly, the liminal stage should not be held as a totally universal part of the rites of passage, as again, this model is based on male initiation rites. As Barry Stephenson claims, "Some passage rites may involve liminal processes but making liminality the heart of all passage rites is to closely associate them with rites of inversion, leading to a distended typology of rites, and implicitly grants greater moral and religious worth to rites emphasising liminality and anti-structure, rather than status system and structure."

Thirdly, Eliade's claim about the desacralisation of the 'modern man' and the disappearance of the rites of passage should be mentioned. This thesis argues that rites of

\footnotetext{
${ }^{45}$ Encyclopaedia of Religion, $2^{\text {nd }}$ ed., s.v. "Initiation: An Overview."

${ }^{46}$ Ibid.

${ }^{47}$ Bell, Ritual: Perspectives and Dimensions, 95.

${ }^{48}$ Ibid.

${ }^{49}$ Encyclopaedia of Religion, $2^{\text {nd }}$ ed., s.v. "Rites of Passage: An Overview [Further Considerations]."

${ }^{50}$ Ibid.
} 
passage have never ceased to exist despite the modernisation of the world. Although they might have gained different forms, these forms are by no means to be considered 'worse' than the traditional ones. ${ }^{51}$ For example, Louise Carus Mahdi argues that these rites took on different forms or emerged in unconscious acts. She claims that:

"The need for some kind of initiation is so important that if it does not happen consciously, it will happen unconsciously, often in a dangerous form. Fulfilment of the deep need for initiation in our world today seems to have less conscious forms than they had in the past. Today images and symbols of ancient rites of passage are frequently found in dreams, fantasies, and in the unconscious acting out by people of all ages." 52

However, with this argument Mahdi seems to be dangerously close to Eliade's claim that the sacred in the modern world emerges only through repressed, unconscious forms. She is correct though, that modernity brought huge changes to ritual (and the understanding of ritual), together with the discussions on the need for initiation in the modern West and the need to rethink the major life-cycle rites such as leaving home, divorce, graduation, retirement, etc. Rites of passage and initiation rites have to be revised and reassessed. ${ }^{53}$ Every culture inevitably creates its own rituals and myths surrounding them, which serve to explain human existence, for the validation of the social order and marking the entry into the different stages in life. That is why the analysis of initiation rites in Pelevin's prose will provide us with meaningful insights about this change and the reassessment of the rites of passage. The fifth chapter will deal with Pelevin's subversion of the usual understanding of initiation and sacrifice. His works show that the mechanism of initiation in a post-Soviet milieu might be distorted and the outcome might be far from what is traditionally expected. Pelevin's prose might both confirm the value of the ritual theories and present a challenge to them.

Initiation is saturated with liminality, even though the universality of liminality in this rite might be questioned. This notion is discussed in the next section.

\footnotetext{
${ }^{51}$ However, one has to be careful as it is possible to label any life crisis a 'rite of passage', thus stretching this term beyond its limits and making it meaningless.

${ }^{52}$ Louise Carus Mahdi, "Introduction," in Betwixt and Between: Patterns of Masculine and Feminine Initiation, ed. Louise Carus Mahdi, Steven Foster and Meredith Little (La Salle, Ill.: Open Court, 1987), xiii.

${ }^{53}$ While certain rites of passage, such as birth or marriage, could lose their religious significance, other rites have emerged, such as owning one's first car, leaving home, getting the first job. (Bell, Ritual: Perspectives and Dimensions, 100.)
} 


\subsection{Liminality}

A huge contribution to the discussions on liminality was made by British cultural anthropologist Victor Turner. One of the most influential ritual theorists of the $20^{\text {th }}$ century, he dedicated his works to ritual, symbols and the ultimate question of how ritual and symbolic systems enable people to make sense of their life, to create meanings, to place themselves in the cosmos and eventually in the certain social places. Studying non-Western societies (specifically the African tribe Ndembu in Zambia), he analysed the role of rituals and symbols in social situations.

As Robert A. Segal claims, Turner considered religion to be the key to culture and ritual to be the key to religion. ${ }^{54}$ Ritual is never meaningless. It is never a performance for performance's sake - it carries sacred information. Ritual "occurs in society as a process of feelingful communication wherein beliefs about the cosmos and society are transmitted through expressive and symbolic behaviour." 55 According to Turner, ritual separates members of a group from everyday life, places them in limbo and then returns them, in some sense, transformed. ${ }^{56}$ Rituals are processual; these processes can be defined and discussed.

However, it was the folklorist Arnold van Gennep who first distinguished the three stages in rites of passage; namely, segregation, transition (margin, or limen), and incorporation. The first stage includes a separation of the ritual object from its old place in the community. The second, or liminal stage, is transitory and has special attributes that are discussed below. The final stage includes the incorporation of the ritual object into its new position in the community. ${ }^{57}$ Victor Turner further expanded Gennep's theory, paying special attention to the transition, or liminal phase.

Liminality for Turner was a core concept when talking about rituals. He "treated one rite of passage, initiation, as the quintessential rite of passage, and he regarded one of its phases, liminality, as definitive of ritual. ... The liminal had moral and religious worth. It was to become the generative, therefore primary, principle of ritual in particular and culture in general." ${ }^{58}$ During the liminal or marginal state (limen in Latin means threshold) the ritual

\footnotetext{
${ }^{54}$ Robert A. Segal, "Victor Turner's Theory of Ritual," Zygon 18, no. 3 (1983): 327-35.

${ }^{55}$ Kathryn Madden, "Ritual, Drama, and the Unconscious in the Eucharist: Contributions of Victor Turner to Depth Psychology and Religion," Union Seminary Quarterly Review 53, no. 1-2 (1999): 111.

${ }^{56}$ Victor W. Turner, The Anthropology of Performance (New York: PAJ Publications, 1986), 25.

${ }^{57}$ More about Gennep's threefold scheme in Arnold van Gennep, The Rites of Passage (London: Routledge \& Kegan Paul, 1960 - the original year of publishing is 1909).

${ }^{58}$ Grimes, "Ritual," 264.
} 
object is ambiguous: "he passes through a cultural realm that has few or none of the attributes of the past or coming state. ${ }^{, 59}$ People, experiencing liminal states, are betwixt and between, in and out, neither here nor there, cut off from their usual social life: "liminality is frequently likened to death, to being in the womb, to invisibility, to darkness, to bisexuality, to the wilderness, and to an eclipse of the sun or moon." ${ }^{, 60}$ As these people are no longer (and not yet) classified, they are represented with symbols of death, decomposition, and other processes with negative meaning, in other words - treated as (neither living nor) dead. Moreover, they are regarded as polluting. ${ }^{61}$ The old identity is left aside, and the new one is not yet gained. A person in a liminal state lives having no clearly defined role and position in society. Sexless, status-less, invisible, unclassified, anonymous, possessing nothing - their condition is, in Turner's words, "the very prototype of sacred poverty." The important moment concerning the liminal phenomena for him was the "blend they offer of lowliness and sacredness." 62 The social borders between the groups of adepts disappear. They become absolutely equal: naked in the figurative or the literal sense of this word, without any signs marking their social position in the community. All of them become the same, and a special relationship emerges between them. To name such a group Turner developed the notion of communitas.

Turner preferred the term 'communitas' to 'community' in order to distinguish that special relation amongst the members of this group from the usual relationships. Communitas is defined as a temporary, unstructured community where all members are equal. Communitas is a spontaneous, unstructured, sudden expression of sociability. It is here and now: "the Zen formulation 'all is one, one is none, none is all' well expresses the global, unstructured character earlier applied to communitas. ${ }^{, 63}$ Thus communitas can function as a certain 'altered state' of being in the community. Communitas is almost everywhere held sacred, "possibly because it transgresses or dissolves the norms that govern structured and institutionalized relationships and is accompanied by experiences of unprecedented potency." $" 64$

\footnotetext{
${ }^{59}$ Victor W. Turner, The Ritual Process: Structure and Anti-Structure (London: Routledge \& Kegan Paul, 1970), 94-95.

${ }^{60}$ Ibid., 95.

${ }^{61}$ Victor W. Turner, The Forest of Symbols: Aspects of Ndembu Ritual (New York: Cornell University Press, 1967), 96-97.

${ }_{62}$ Turner, The Ritual Process, 96.

${ }^{63}$ Ibid., 112-113.

${ }^{64}$ Ibid., 128.
} 
Many scholars, including Tim Olaveson, argued that in many ways Turner was influenced by Durkheim and that his collective effervescence and Turner's communitas are functionally equivalent concepts. ${ }^{65}$ To start with, it was Durkheim who 60 years earlier claimed that the idea of ritual is the basis of religion and of society in general. For him, ritual was a means of bringing people together, to strengthen the bonds which connect a person to their society. Durkheim treated ritual as "the rules of conduct governing human activity in the face of the sacred." 66 Ritualistic gatherings meant to venerate the sacred enabled people to experience a collective effervescence, "an emotional state through which they came to identify themselves with their gods." 67 Thus the significant link between the Durkheimian notion of ritual and collective effervescence and Turner's ritual theory and concept of communitas is evident. Durkheim stressed the communal and collective aspects of collective effervescence: "Collective effervescence, especially creative effervescence, thus implies dissolution of regular social and normative structures, and is sometimes seen as a danger to these structures. This is exactly the process Victor Turner describes in the emergence of communitas. ${ }^{\prime 68}$ As Durkheim did with sacredness and collective effervescence, Turner also linked sacredness and communitas as set apart from social structure, although he emphasised that it should not be equated with the sacred. Olaveson concludes his discussion by saying that "both men were writing about the same phenomenon, although to differing degrees of depth and precision.",69

Beyond doubts, both liminality and communitas can be attributed not only to the specifically religious rituals in the traditional societies, but also to the modern phenomena. This will be illustrated in the subsequent chapters where the post-Soviet condition and literature are examined. Turner distinguished three possible types of communitas in society:

1) Spontaneous, or free from social demands;

2) Normative, or organised into a social system;

3) Ideological, which "refers to Utopian models of societies based on existential communitas and is also situated within the structural realm."70

\footnotetext{
${ }^{65}$ Tim Olaveson, "Collective Effervescence and Communitas: Processual Models of Ritual and Society in Emile Durkheim and Victor Turner," Dialectual Anthropology 26 (2001): 89-124.

${ }^{66}$ Catherine M. Bell, "Ritual," in The Blackwell Companion to the Study of Religion, ed. Robert Alan Segal (Malden, MA: Blackwell Pub., 2006), 400.

${ }^{67}$ Ibid.

${ }^{68}$ Olaveson, "Collective Effervescence and Communitas," 102.

${ }^{69}$ Ibid., 106.

${ }^{70}$ Mathieu Deflem, "Ritual, Anti-Structure, and Religion: A Discussion of Victor Turner's Processual Symbolic Analysis," Journal for the Scientific Study of Religion 30, no. 1 (1991): 15.
} 
According to this classification, the hippie movement can be regarded as having gone through these three stages. Thus when talking about hippies, Turner emphasises that what these dharma bums searched for in their communities was not a simple friendship or unity - it was a transformative experience, which enables finding profoundly communal and shared phenomena.

Turner also proposed the term 'liminoid', which differs from liminal in a sense that it refers to optional liminal experiences diffused in the modern industrial world. These experiences are a kind of a break from society, the traces of which can be seen in art, advertising, politics, and culture. It is the liminoid that is sacred to the members of secular society, claims Turner, characterising the liminoid in terms of the sacred, for example, as an intense feeling, the dismantling of hierarchy. ${ }^{71}$ However, Turner was criticised for underestimating the distinction between the liminal and liminoid and did not clearly separate the so-called primitive and modern societies:

"On the one hand, he considered all rituals to have religious connotations. On the other hand, he typified both tribal rituals and religious rituals in industrial societies (which are confined to the realm of institutionalized religion) as liminal, while rituals in the recreational domain of modern society were termed liminoid.",72

According to Turner, liminal experiences in contemporary society are replaced by the liminoid. "The liminoid is constrained by no particular type of ritual - not initiation, pilgrimage or festival - so the liminoid is virtually synonymous with cultural creativity, imagination actively rendering the world a more habitable place., ${ }^{, 73}$ This notion is now subject to criticisms. For example, the anthropologist Gananath Obeyesekere opposes the use of the term saying that "the restriction of the liminal to special localized arenas in complex societies makes for too artificial a distinction between preliterate and industrial cultures.",74 With this argument Turner falls into a universalistic trap, making a distinction of the liminal experiences 'then' and 'now', and resembles Mircea Eliade, who argued that modern society faces the degradation of the sacred. That said, the term 'liminoid' seems to be problematic and therefore is not used in this research.

\footnotetext{
${ }^{71}$ Ronald L. Grimes, "Victor Turner's Definition, Theory, and Sense of Ritual," in Victor Turner and the Construction of Cultural Criticism: Between Literature and Anthropology, ed. Kathleen M. Ashley (Indiana: Indiana University Press, 1990), 145.

${ }^{72}$ Deflem, "Ritual, Anti-Structure, and Religion," 17.

73 Grimes, "Ritual," 266.

${ }^{74}$ Gananath Obeyesekere, quoted from Encyclopaedia of Religion, $2^{\text {nd }}$ ed., s. v. "Liminality."
} 
A significant shift of thinking is Turner's identification of sacrality with liminality and secularity with social structure, having in mind that according to previously discussed ideas, sacrality was held to be an unchangeable structured entity: "When sacrality came to be identified with liminality, a new view of ritual was possible."75 As noted in the first chapter, the sacred in this research is regarded as not a permanent category. Liminality can thus be regarded as a transformative experience, which enables us to form new sacred structures, becoming one of the potential sources of the sacred. In liminal states, the search for the sacred can be actualised.

By no means though should liminality be treated as a universal term in this research. Universalising is also one of the main criticisms for Turner's work. Beyond doubts, the term 'liminality' can become problematic when being applied almost anywhere. This problem will be further discussed in the fourth chapter, together with the types of liminality in post-Soviet literature and beyond. The notion of permanent liminality and its applicability in the postSoviet context will also be mentioned and questioned. The fourth chapter will also link liminality to the notions of sacred space, time, and persons, and explore the tension between the liminal and the sacred. Meanwhile, the next section presents the non-conventional manifestations of the sacred.

\subsection{The Alternative Quest for the Sacred}

"If you really wish to commit yourself to the spiritual quest, you must learn how to use psycho chemicals. Drugs are the religion of the twenty-first century.",76

The third chapter will note the notorious claim that sex, drugs, and alcohol 'did not exist' in the Soviet Union. Apparently there was no need to escape from the best of societies. The break-up of the Soviet Union clearly demonstrated the absurdity of this claim. This section presents a theoretical background, which will later help analyse the phenomenon of sacred substances in Pelevin's prose, their role, and whether they can become a means to connect with what a person considers sacred.

The use of psychedelic substances for communication with the supernatural realm, ultimate reality or with the 'higher self' is not an invention of modern times. For many

\footnotetext{
${ }^{75}$ Grimes, "Ritual," 265.

${ }^{76}$ Timothy Leary, quoted from Christopher Partridge, The Re-Enchantment of the West, Volume 2, Studies in Sacralization and Occulture (London: T\&T Clark, 2006), 96.
} 
centuries they were used as a means for communication with gods, for entering the transcendent sphere and for getting in touch with what was considered sacred.

Various plants served for ritual purposes in most archaic societies, from haoma in the Persian Zend Avesta to soma in Indian literature (perhaps the most obvious early mentioning of psychedelic substances in sacred writings is in the Rig Veda with 120 hymns devoted to soma, a psychoactive plant visualised as a deity), ${ }^{77}$ marijuana (also known as ganja, hashish, cannabis) in most parts of the world, including North and South America, India, China, Africa, and peyote in Mexico, to name a few. ${ }^{78}$

Closer to our times, the 1960s and 1970s saw the blossoming experimentation with various psychedelic substances until they became illicit starting in $1966 .{ }^{79}$ However, the controversy surrounding the substances continues to this day. Eventually, by the end of the $20^{\text {th }}$ century, psychedelics started making a comeback, even gaining the right to be a legal part of ritual - like consecrated bread and wine in the Catholic Mass. ${ }^{80}$ This fact indicates not only an acknowledgement of 'the other' and their right to have a different value and belief system, but also a certain acknowledgement of psychedelics being used as a part of ritual and for the spiritual search. That said, the significance of these substances for the sacred is evident.

Traditionally, the use of psychedelics is divided into recreational and so-called spiritual, that is, the search for transcendental experiences. In the latter case these psychedelic substances are also called 'entheogens', thus associating them with any kind of a spiritual quest. The term 'entheogen' traditionally refers to psychoactive substances, which someone uses with the intention of transforming or experiencing another reality for the purpose of development. However, this division also implies a dichotomy of the 'profane' (recreational) use of psychedelics, as opposed to the 'sacred' use, which is directly connected to transcendental experiences. As mentioned, this dichotomy of the sacred and the profane can no longer be applied when speaking of the sacred in contemporary society. Therefore, the recreational use of psychedelics is not to be dismissed as it can equally reflect people's search for what they perceive as sacred. Whatever the initial purpose and aim for using psychedelics,

\footnotetext{
${ }^{77}$ Partridge, The Re-Enchantment of the West, 83.

${ }^{78}$ Stanislav Grof, The Adventure of Self-Discovery (Albany: State University of New York Press, 1988), 275-6.

${ }^{79}$ The State of California's ban on LSD took effect on October 6, 1966.

${ }^{80}$ According to Religious Freedom Restoration Act (1993) and a US Supreme Court ruling regarding the transportation of peyote in 1994, the members of the Native American Church were guaranteed the right to both use peyote during ceremonies and transport it from the gathering fields. The same goes to ayahuasca tea, which was allowed to use for religious purposes for União do Vegetal in 2006. (Encyclopaedia of Religion, $2^{\text {nd }}$ ed., s. v. "Native American Church.")
} 
recreational or spiritual, the ultimate result is an escape from the surrounding everyday reality and entering another world, time and space. As the distinction between the recreational, or 'profane' and spiritual use of psychoactive substances proves not to be useful for this research, I will avoid using the term 'entheogen'. Also, the impact of psychedelic substances will be named 'altered states', avoiding such terms as religious, transcendental, or spiritual experiences that are used (sometimes uncritically) in the scholarly sources, when describing the effect of psychedelics.

These experiences can be gained by manipulating the physiological processes of the human body (not only with drugs, but also sensory deprivation, pain, sleeplessness and fatigue, and deprivation of food and water). Moreover, it is also said that such manipulation "by any means available to produce euphoria, dissociation or hallucination is one of the nearly universal characteristics of religion. $" 81$

The main feature of these altered states, induced by psychedelic substances, is the sense of unity, absolute, or emptiness, speaking in Buddhist terms. The boundaries between subject and object merge, and the universe is perceived "as whole, good and purposeful.",82 Moreover, this delusion is considered by those experiencing it as a fundamental reality, and this reality becomes far more 'real', more vivid and attractive. Following these experiences of the unitary consciousness, a return from this travel can be painful and depressing. ${ }^{83}$ The psychedelic experiences are not necessarily always blissful. There can be encounters with loneliness, guilt, and realisations of mortality, followed by a kind of shamanic rebirth. ${ }^{84}$

In archaic societies and today during religious ceremonies the use of psychedelic substances has been restricted to particular times, places, and occasions, and to certain people. ${ }^{85}$ The consumption of sacred substances is considered a sacred act, and being in an intoxicated state is interpreted as a sacred experience, allowing communication with the spiritual world. Paradoxically, psychedelics became not only a means to reach what is perceived as the sacred, but also a certain form of that sacred, a 'holy communion'. As one of the advocates for the use of mind-altering substances, Stanislav Grof, claims, if psychedelics

\footnotetext{
${ }^{81}$ Anthony F. Wallace, quoted from Encyclopaedia of Religion, $2^{\text {nd }}$ ed., s. v. "Psychedelic Drugs."

${ }^{82}$ Encyclopaedia of Religion, $2^{\text {nd }}$ ed., s. v. "Psychedelic Drugs."

${ }^{83}$ The ecstatic state induced by drugs is called travel/trip (a cocaine trip in cases when this drug is being used).

${ }^{84}$ David Fontana, Psychology, Religion and Spirituality (Malden: BPS Blackwell, 2003), 154.

${ }^{85}$ For example, in pubertal initiatory rituals by shamans entering into altered states.
} 
can induce mystical experiences, then they are not ordinary chemicals but sacred substances, or sacramentals. $^{86}$

However, it can also be stated that nowadays "a Pandora's box of altered states, heavens and hells, highs and lows, trivia and transcendence cascaded into a society utterly unprepared for any of them." ${ }^{87}$ With the synthesis of LSD (by Albert Hofmann in 1938) the Western history of psychedelics began. Christopher Partridge divides the three phases of the so-called modern spiritual psychedelic revolution: the first starting from the invention of Albert Hoffman, ${ }^{88}$ the second taking place in 1960 s and the third associated with the rave culture from the late 1980s. Psychedelics were also used to induce altered states of consciousness in various New Age practices, ${ }^{89}$ quickly becoming a part of them in the 1960s, as well as in some of the new religious movements. ${ }^{90}$ On the one hand, spiritual seekers were keen to try various ways in the search of their path to enlightenment, and psychedelics, along with yoga and meditation, served this purpose well. ${ }^{91}$ On the other hand, some researchers also claim that for certain people, the experiments with psychedelics awakened their interest in the spiritual search, and this experimentation helped them to redirect their lives. ${ }^{92}$

Controversy surrounding psychedelics continues to this day, from the claims that what they induce are not authentic spiritual experiences, to the opinion that they can be a tool for one's spiritual practice (when used responsibly). Huston Smith argued that the experiences induced by psychedelics are authentic but do not necessarily result in a "spiritual way of being": "unless they happen in the right context and are followed by systematic spiritual

\footnotetext{
${ }^{86}$ Stanislav Grof, "The Potential of Entheogens as Catalysts of Spiritual Development," in Psychoactive Sacramentals: Essays on Entheogens and Religion, ed. Thomas B. Roberts (San Francisco: Council on Spiritual Practices, 2001), 41.

${ }^{87}$ Roger Walsh and Charles S. Grob, "Psychedelics and the Western World: A Fateful Marriage," in Higher Wisdom: Eminent Elders Explore the Continuing Impact of Psychedelics, ed. Roger Walsh and Charles S. Grob (New York: State University of New York Press, 2005), 1.

${ }^{88}$ However, even earlier, at the turn of the century, the notorious occultist and magician Alester Crowley, amongst others, also claimed that hashish can open 'the gate to the Other-world', arguing that it should be used along with the techniques of meditation and magic. (Partridge, The Re-Enchantment of the West, 86.)

89 Jerome Beck and Marsha Rosenbaum, Pursuit of Ecstasy: The MDMA Experience (New York: State University of New York Press, 1994), 36-41.

${ }^{90}$ As usual, there is a thin line between the use and abuse of psychedelics, the latter becoming a two-edged sword. Take, for example, the aim of hippies' pilgrimages to Goa in the 1970s: did it serve as a spiritual enlightenment, psychedelic trances, or just the ultimate partying?

${ }^{91}$ James Fadiman presents a description of his experience: "I moved into a space of feeling that I was - not part of everything - but that everything was part of everything, and I was clearly part of that. Suddenly, it was obvious there is no death, and that the fundamental waveform of the universe is best described in human terms as love. This was all incredibly obvious. ... I looked out, and had an amazing feeling of identification with Creation. The 'I' here was clearly not me, not Jim Fadiman, but the 'I' was pleased with Creation, and pleased that part of me was observing other parts of me." (James Fadiman, "Transpersonal Transitions: The Higher Reaches of Psyche and Psychology," in Higher Wisdom: Eminent Elders Explore the Continuing Impact of Psychedelics, ed. Roger Walsh and Charles S. Grob (New York: State University of New York Press, 2005), 29.)

${ }^{92}$ Walsh and Grob, "Psychedelics and the Western World," 3.
} 
practice, they are not in the same category as those experiences that we read about in the spiritual literature." 93 He claimed that "it is indeed possible for chemicals to enhance the religious life, but only when they are set within the context of faith (on the conviction that what they disclose is true) and discipline." 94

Those advocating psychedelics employ spiritual terminology and define the experience as 'being closer to god': "It's an experience of the core self of sometimes called the God-space or the peaceful center, or somebody once described it as experiencing themselves being held in the hands of God." 95 They also claim that the therapeutic and spiritual potential of psychedelics could be realised if people were taught how to use them properly. In the 1960s psychedelics were popularised by Timothy Francis Leary, a psychologist at Harvard University, and others, who held the notion that they produced genuine religious experiences. In the 1950s Aldous Huxley's experiments with mescaline began, and he shared this experience in The Doors of Perception (1954), describing it as a feeling of "pure being" and "the divine source of all existence". ${ }^{96}$ Meanwhile, the opponents of the psychedelic use for spiritual seeking frequently used Baudelaire's argumentation, claiming that there are no shortcuts to paradise. ${ }^{97}$

Aldous Huxley, Alan Watts, and Timothy Leary all had a significant influence on the 1960s psychedelic culture (the second phase). ${ }^{98}$ Two decades later, LSD was replaced by MDMA (Ecstasy). As psychiatrist Norman Zinberg states, MDMA is "the psychedelic for the '80s. It's no big deal. It's mild. You've still got the taste of danger without the impact of

\footnotetext{
${ }^{93}$ Grof, "The Potential of Entheogens," 42.

${ }^{94}$ Huston Smith, Cleansing the Doors of Perception: The Religious Significance of Entheogenic Plants and Chemicals (New York: Jeremy P. Tarcher/Putnam, 2000), 31.

95 Jerome Beck and Marsha Rosenbaum, Pursuit of Ecstasy: The MDMA Experience (New York: State University of New York Press, 1994), 39. Another respondent sees the purpose of MDMA as producing the sense of acceptance: "I think that the preeminent aspect of MDMA is a sense of acceptance. That, I think, produces the timelessness - you just accept you're not going anywhere ... that's why I've used it with monks, rabbis, Zen Buddhist priests, as an aid to meditation in 25 to $50 \mathrm{mg}$. doses, some very preeminent and prominent." (Ibid.)

${ }^{96}$ Aldous Huxley, in Partridge, The Re-Enchantment of the West, 89. Huxley also stated that "in a similar way to meditation, psychedelics enable people to breach the fence between their conditioned minds and the larger spiritual environment, thereby giving them access to 'a new direct insight into the very Nature of Things'." (Ibid., 92.)

${ }^{97}$ Ibid., 90.

98 That is how Leary explains his famous philosophy 'turn on, tune in, and drop out': "Drop out - detach yourself from the external social drama which is as dehydrated and ersatz as TV. Turn On - find a sacrament [i.e. LSD] which returns you to the temple of God, your own body. Go out of your mind. Get high. Tune In - be reborn. Drop back in to express it. Start a new sequence of behaviour that reflects your vision." (Partridge, The Re-Enchantment of the West, 100-101.) Leary with others also produced an influential psychedelic text "The Psychedelic Experience: A Manual Based on the Tibetan Book of the Dead," thus closely relating psychedelics to the Easternised spirituality of the West.
} 
LSD. It's yuppie psychedelic." 99 While mood altering, the empathogenic Ecstasy was not the same as psychedelics like LSD. It "did not have the same sort of 'spiritual' or 'transcendent' impact that LSD did in the 1960s. It tended to lead simply to egotic hedonism, rather than spiritual quest.",100

The third phase of the modern psychedelic revolution is dance, or rave culture, which is worth briefly mentioning as it is closely related to psychedelic culture. Like chemical substances, certain types of music can induce an ecstatic state, which some scholars compare with religious trance. ${ }^{101}$ However, music parties and psychedelic substances often go hand-inhand, with the DJ becoming a modern pseudo-spiritual leader and a guide in this psychedelic journey. ${ }^{102}$ "God is a DJ," or "Last night the DJ saved my life,"103 the current young generation claims, taking part in rave sessions, which could be defined as creating certain communitas. They also resemble rituals: a certain (set apart) time and place, dancing, sleep deprivation, fasting, and the use of psychedelics. In such rave events MDMA can be ingested collectively as the "holy sacrament." 104 Moreover, based on the correlation between the drug choice and music genre it was also suggested, that 'psytrance' ravers choose LSD, the 'hardcore' choose crystal methamphetamine, the 'jungle' and 'hip-hoppers' - cannabis, and for 'house' and 'techno' types - MDMA. Drugs are selected based on how they complement the music's emotional features and the beat per minute range. ${ }^{105}$

Speaking of mid-90s Britain, Simon Reynolds divided the nation into two societies, passive and active: the traditional leisure culture of alcohol and passive entertainment, usually TV, versus the Ecstasy, dancing and active participation. ${ }^{106}$ Post-Soviet examples can present different dualities. As noted, one of the tasks in this research will be to disclose

\footnotetext{
99 Jerome Beck and Marsha Rosenbaum, Pursuit of Ecstasy: The MDMA Experience (New York: State University of New York Press, 1994), 34.

${ }^{100}$ Partridge, The Re-Enchantment of the West, 109.

${ }^{101}$ A good source of the contemporary research on spirituality and rave music is the multi-author volume, edited by Graham St. John: Rave Culture and Religion (London; New York: Routledge, 2004).

102 "Using equipment to manipulate the rhythm, sound, and lighting, the DJ guides individuals through a psychological journey where the dance floor transcends its function as a space for leisure activity. For man, this is a sacred arena for transformation, healing, and spirituality; the dance floor is a 'pseudo church'; and the DJ is a revered figure whose role borders the divine." (Melanie Takahashi, "Spirituality through the Science of Sound: The DJ as Technoshaman in Rave Culture," in Call Me the Seeker: Listening to Religion in Popular Music, ed. Michael J. Gilmour (New York; London: Continuum, 2005), 240.) Takahashi's dissertation also deals with the topic of music and the contemporary spirituality (Takahashi, Melanie. "Theater in Search of Storyline: The Role of the 'Technoshaman' in Rave Culture.” PhD diss., University of Ottawa, 2004).

103 "God is a DJ" is a single by American pop singer Pink, whereas "Last Night a D.J. Saved My Life" is a song written by Michael Cleveland for the group Indeep.

104 Takahashi, "Spirituality through the Science of Sound," 252.

105 Ibid., 264.

106 Simon Reynolds, Generation Ecstasy: Into the World of Techno and Rave Culture (New York: Routledge, 1999), 237.
} 
whether it is possible to talk of the sacred dimension in the contemporary use of the substances. Both recreational and spiritual uses of psychedelics are equally important, both can reflect the search for the sacred, and they will be discussed in the sixth chapter.

\subsection{Conclusions}

This chapter discussed the theoretical tools for the study of the sacred in Victor Pelevin's prose and classified the manifestations of the sacred as conventional and nonconventional. This structure will later help when discussing the literary examples. The fourth and the fifth chapters will provide a discussion on the conventional forms of the sacred, whereas the sixth and the seventh chapters will focus on the non-conventional forms.

In summary, such categories as ritual, sacred space, sacred persons, and sacred substances will be used beyond their religious contexts. These categories will be applied in the study of such secular terrain as post-Soviet literature. The concept of liminality will also be broadly applied while talking about post-Soviet literature and beyond. The next chapters will show the importance of rethinking these classical concepts in order to interpret Pelevin's works and fully grasp their meanings. His prose might both confirm the value of the ritual theories and present a challenge to them.

Particular attention will be given to sacred substances as an illustrative example of the non-conventional forms of the sacred. In the new millennium psychedelics might regain their popularity, as more and more people seek non-conventional, alternative spiritualities. The search for the alternative forms of the sacred, expressed through the use of psychedelics (or, alternatively, alcohol or TV images, as discussed in the sixth chapter), becomes a form of escape, which will be thoroughly discussed in the last two chapters. The role of sacred substances in post-Soviet literature provides us yet another possibility to open up 'the doors of perception' to what is sacred for post-Soviet society. The next chapter will serve both as an introduction to the post-Soviet condition and a start of the discussion on the sacred in the post-Soviet milieu. 


\title{
Chapter 3: The Post-Soviet Condition: Reinventing the Sacred
}

\author{
"It was a very strange world. Externally it had not changed too much, except \\ perhaps that there were more paupers on the streets, but everything in his \\ surroundings - the houses, the trees, the benches on the streets - had somehow \\ suddenly grow old and decrepit. It wasn't possible to say that the essential nature of \\ the world had changed, either, because now it no longer had any essential nature. A \\ frighteningly vague uncertainty dominated everything."1
}

The above quote presents Victor Pelevin's glance into how the world had changed after the break-up of the Soviet Union. The uncertainty in this quote constituted a code word that became one of the dominant feelings in the early post-Soviet years. This chapter presents a general cultural-historical context of those years and introduces the milieu where Pelevin's prose was born. It attempts not only to register major historical and political facts and dates, but also to explore what lay behind those dates. What does it mean to be Russian (and no longer Soviet) after the Soviet Union? Who are these people if they are no longer Communists? How does one live in chaos, in an anti-structure, in a liminal world, and how does one create a new structure, identity, and meaning, in other words, a new sacred? This chapter dwells on the question of how, in S.M. Vladiv-Glover's words, post-Soviet Russians constructed a new reality through their own modern mass idiom and new social models. ${ }^{2}$

Without a doubt, Russia has experienced dramatic changes over the past years. ${ }^{3}$ The Soviet Union did not favour change - it was not considered politically or economically advantageous. Change, as people tended to think, was always for the worse. ${ }^{4}$ As the Soviet Union presented itself as the "eternal state" (vechnoe gosudarstvo), ${ }^{5}$ most people were not

\footnotetext{
${ }^{1}$ Victor Pelevin, Homo Zapiens, trans. by Andrew Bromfield (New York: Viking, 2002), 6 (emphasis mine).

${ }^{2}$ Slobodanka M. Vladiv-Glover, "From Bread Dolls to Prostitutes: A Cultural Diagnosis of Post-Soviet Russia," Georgetown Journal of International Affairs 8, no. 1 (2007): 93.

${ }^{3}$ Jarret Zigon argues that such social, cultural, and political changes were the nature of Russia over the last few centuries: "From the reforms of Peter to the massive increase of industrialization and production at the turn of the century that brought with it a massive shift of population to the urban centres to the Bolshevik revolution and Civil War, from Stalin's modernization and collectivization projects and their accompanying purges to the devastation of the war to the vast post-war changes that led to the stabilizing of everyday life, the last few centuries have indeed been a series of intense changes for the country and the Russian people." (Jarret Zigon, Making the New Post-Soviet Person: Moral Experience in Contemporary Moscow (Leiden: Brill, 2010), 4.)

${ }^{4}$ Christoph Neidhart, Russia's Carnival: The Smells, Sights, and Sounds of Transition (Lanham, MD: Rowman \& Littlefield, 2002), 35.

5 Alexei Yurchak, Everything Was Forever, Until it Was No More: The Last Soviet Generation (Princeton: Princeton University Press, 2006), 1.
} 
prepared for the transformation of their world, which happened seemingly overnight. These changes had an enormous impact on post-Soviet culture, mentality, and literature. Accordingly, these changes also had an impact on the perception of the sacred. Namely, what took place in the post-Soviet era, and especially at its beginning, was a radical rethinking of sacrality. However, a discussion about the post-Soviet sacred is hardly possible without an excursion into what was considered to be sacred in the Soviet era. Therefore, this chapter first briefly overviews the break-up of the Soviet Union, then discusses the social, religious, and psychological situation in post-Soviet society and the major changes that took place there. Finally, a few words are said about the literary scene in post-Soviet Russia. This chapter attempts to draw a spiritual map of the post-Soviet people and explore their core values, beliefs and their newly forming identities, as compared with their lost Soviet identities.

It can be argued that post-Soviet Russia is still at the threshold, undergoing a transitional stage, best defined by Victor Turner's concept of liminality. ${ }^{6}$ As Christoph Neidhart poetically exclaimed:

"Today's Russia smells different from the Soviet Union, and different from Russia of any previous time. Russia looks different - as do the other post-Communist societies compared to before the fall of Communism. Russia sounds different, her touch is different, the food tastes as never before."7

Thus the aim of this chapter is to explore this transformation process, to describe this difference, and finally, to contextualise Pelevin's prose.

\subsection{The End of the 'Eternal State'}

The $20^{\text {th }}$ century, especially its second half, is marked with the prefix 'post.' The brave new world became post-industrial, post-Marxist, post-structuralist, postmodern, and eventually, post-Soviet. ${ }^{8}$ This word found a perfect niche in the territories that had yet to be named.

\footnotetext{
${ }^{6}$ The notion of liminality (namely, liminality in Pelevin's texts) will be further evolved in the fourth chapter, section 4.5 .

${ }^{7}$ Neidhart, Russia's Carnival, 1.

${ }^{8}$ As Slobodanka M. Vladiv-Glover states, “if 'post' means anything at all, it signifies the 'end of history' or 'poste histoire', which implies the demise of linear thinking about history as progress and human development as proceeding along a continuum." (Vladiv-Glover, "From Bread Dolls to Prostitutes," 87.)
} 
This research uses the term 'post-Soviet' to name the time period, which began after the break-up of the Soviet Union in the early 1990s. ${ }^{9}$ It faces the epoch that had yet to be defined. The break-up of the Soviet Union is definitely too complex a process to be thoroughly analysed in the frames of this research. However, it is essential to briefly discuss the main reasons of this split.

In 1985, after the death of terminally ill Konstantin Chernenko, a relatively young, reform-oriented Mikhail Gorbachev replaced him as General Secretary of the Communist Party of the Soviet Union. This was the end of the period of stagnation. During his years as General Secretary, Gorbachev launched radical political and economic reforms that were meant to transform society. Choosing political liberalisation, Gorbachev clearly declared the need for democratisation and openness (glasnost).

This encouragement actually opened the flood gates. The term restructuring (perestroika) entered into the vocabulary of the Soviet people. However, most of those people - who had experienced 'The Thaw' period lasting from 1956 to 1968 during which many Stalinist atrocities were revealed, and faced the period of political, social, and cultural stagnation during the years when the former General Secretary Leonid Brezhnev was in power - could not easily believe these changes were really possible.

But soon enough the words were replaced by actual reform. The broader aim of the reform, as Christopher Read notes, was not only to improve living standards, but also to create a 'healthy' and 'normal' society in the Soviet Union in which "citizens would take greater responsibility on their own lives and 'civil society' would take over many of state's functions." ${ }^{10}$ What was intended to be created was perhaps a compromise between socialism, democracy and the market economy. However, multiple factors, including the bureaucratic machine, ineffective management of the economy, and overall structural inability made these changes difficult to put into practice. This process together with the ideas of glasnost and perestroika went out of control. The inability to regain control eventually caused the

\footnotetext{
9 Another question is whether this term is still valid after more than 20 years. Svetlana Boym also questions whether Russian prefixes 'post-Soviet', 'post-glasnost', and the foreign ones, such as post-totalitarian, postcolonial, postmodern, overlap. (Svetlana Boym, Common Places: Mythologies of Everyday Life in Russia (Cambridge, Mass.: Harvard University Press, 1994), 218.) Elsewhere she claims that "for the mythical tale of 'eternal Russia', historical memory is irrelevant, and so are the prefixes 'post' and 'pre', along with the relationships between modernism and postmodernism, Communism and post-Communism." (Svetlana Boym, "From the Russian Soul to Post-Communist Nostalgia," Representations 49 (1995): 134.) However, although the term 'post-Soviet' may seem unsuitable to define the current state of the country and society, there is no better term yet.

${ }^{10}$ Christopher Read, The Making and Breaking of the Soviet System (Basingtoke: Palgrave, 2001), 204.
} 
dissolution of the Soviet Union that took place from the beginning of 1990 until the end of 1991.

Members left the party in enormous numbers. ${ }^{11}$ At the core of Communism was a belief in an absolute victory and there was no Plan B in case of defeat. The planning system, censorship, and the secret police just ceased to exist. The Stalinist and Leninist heritage was revised and the damage, which the Soviet system had done, was assessed. The media exposed facts that had been kept tightly secret, including Soviet crimes, massive deportations, violation of human rights, and the negative aspects of the system - corruption, drug abuse, and alcoholism. This left the remnants of a superpower having to deal with an economic crisis, inflation, devaluation of pensions, delayed wage payments, and unemployment.

The events in the early 1990s were both celebrated and mourned, however contradictory that may sound. It reflected the nature of the changes and of people facing them, those between fear and hope. The next sections describe that state of in-betweenness and the changing social, mental, moral, and religious worlds of post-Soviet people. Once again the question is posed: what does it mean to be Russian? This question was crucially important at that time because, as Susan Richard noted in her beautifully written Lost and Found in Russia:

"Under communism, nationality was meant to fade away, replaced by a new Soviet identity. Now, whatever their other difficulties, Russia's ex-colonies in central Asia, Caucasus, and the Baltic states were enjoying a newly recovered sense of self. But for the Russians it was not so easy. Ethnicity was not enough, for the Russians were not all Slav. Territory could not be the defining factor either, for this vast land straddling Europe and Asia had no clear boundaries to the west or south. Before the Revolution, the Orthodox Church had bound Russia's imperial subjects together. But although opinion polls showed people were now fascinated by belief, they were not interested in their Church." 12

The next section starts with a discussion on this ambiguous relationship with the Orthodox Church from Soviet to post-Soviet times. It analyses the importance of the church and why it began to lessen in the post-Soviet years, after the primary euphoria of religious freedom. Finally, it also explores the new modes of faith in a post-Soviet milieu.

\footnotetext{
${ }^{11}$ Michael Mandelbaum, "Coup de Grace: The End of the Soviet Union," Foreign Affairs 71, no. 1 (1991/1992): 168.

${ }^{12}$ Susan Richards, Lost and Found in Russia: Lives in a Post-Soviet Landscape (New York: Other Press, 2010), 91.
} 


\subsection{Religion Between Soviet and Post-Soviet Worlds}

As already emphasised in the first chapter, this research regards religion as only one of the sacred's many potential sources. It is possible to analyse different sacred objects from various perspectives in the same society or cultural system if religion is not regarded as a privileged sphere of the sacred. Therefore, it can be argued that religion:

“... is not a separate, clearly bounded sphere, nor a timeless tradition, nor a mere reflection of the social and the political, but is intimately entwined with social life. Nor does the related dichotomy opposing religion and modernity stand much scrutiny. Modern conditions have often stimulated religious belief and practice, if often in new and more self-conscious ways. Religion is examined here as social practice, as part of the process whereby meaning is formed in an individual's life and a community articulates the moralities that help define it." 13

Religion is closely intertwined with politics in Russia. ${ }^{14}$ The religious resurgence in the post-Soviet times cannot be viewed as an independent phenomenon, but as a part of an ongoing process of the social and cultural diversification.

\section{The Orthodox Church in Pre-Soviet Time}

For centuries the Russian Orthodox Church had a huge influence on the social and political life and generally defined the Russian nation. ${ }^{15}$ It was closely intertwined with Russian pan-Slavism and tsarist autocracy and took part in the formation of the collective identity. ${ }^{16}$ Thus, as Willfried Spohn argues, after the break-up of the Soviet Union the Orthodox Church kept on supporting the autocratic-collectivist tendencies in Russian political

\footnotetext{
${ }^{13}$ Mark D. Steinberg, Catherine Wilson, "Introduction: Reclaiming the Sacred after Communism," in Religion, Morality, and Community in Post-Soviet Societies, ed. Mark D. Steinberg and Catherine Wilson (Washington, DC: Woodrow Wilson Center Press co-published by Indiana University Press, 2008), 3.

${ }^{14}$ More importantly, Russia's modern experience "has long been entwined with religion and spirituality, though this has not been a simple story of religion standing opposed to modernization or being supplanted by it." (Ibid., 4-5.)

${ }^{15}$ Moreover, as Nikolai Berdiaev argues, "the Russian people is religious by type and spiritual structure. ... Russian atheism, nihilism, and materialism have taken on a religious coloring." (N. A. Berdiaev, Russkaia ideia: osnovnye problemy russkoi mysli XIX veka i nachala XX veka. Sud'ba rosii, quoted from Laura Engelstein, "Paradigms, Pathologies and Other Clues to Russian Spiritual Culture: Some Post-Soviet Thoughts," Slavic Review 57, no. 4 (1998): 869.)

16 Willfried Spohn, "Transformation Process, Modernization Patterns, and Collective Identities: Democratization, Nationalism, and Religion in Postcommunist Germany, Poland and Russia," in Postcommunist Transformation and the Social Sciences: Cross-Disciplinary Approaches, ed. Frank Bonker, Klaus Muller, and Andreas Pickel (Lanham, MD: Rowman \& Littlefield, 2002), 214.
} 
and civil society, once again becoming a major force in the country's political and religious life.

The date of birth of the Russian Orthodox Church is considered to be 988, when Prince Vladimir of Kiev officially adopted Byzantine Rite Christianity as a state religion of Kievan Rus'. For 1000 years, the church had a major influence in tsarist Russia; however, in 1917 the Bolsheviks declared the separation of the church and the state. ${ }^{17}$ Although the influence of the Orthodox Church began to weaken, its role remained somewhat ambiguous, being an official state preferred religion (this role is yet to be reassessed). ${ }^{18}$ The opening of some KGB archives has revealed evidence of the Orthodox hierarchy's subordination to the Soviet government. ${ }^{19}$

\section{Communism as a Civil Religion}

Scholars tend to speak of the secularisation process in the Soviet Union. However, this research argues that it could be better named not as the secularisation process but rather as a switch to a different mode of the sacred: "Soviet society was not secularized in the sense of a diminishing belief in otherworldliness." ${ }^{, 20}$ One belief system was quickly replaced with another, namely atheism, which for the Party represented the human being's power and ability to live without god:

"To do by himself, by his intellect and his will, through collective action, that Christianity - and especially Russian Christianity - had taught that only God can do; namely, create a universal peace in the hearts of men."21

The Communist Party had made an attempt to remove traditional religious belief from the public and private life of the Soviet people. This was done on multiple levels, minimising

\footnotetext{
${ }^{17}$ The turn of the last century was also the time of a religious renaissance. Many Russians, including wellknown intellectuals, either turned again to the Orthodox Church, or began searching for their own spiritual paths amongst the variations of Eastern religions, spiritualism, mysticism, and theosophy. Thus "the prerevolutionary Orthodox Church's 'internal mission' was as much a response to the perceived threats posed by alternative religiosities as to the spread of secularism and disbelief." (Steinberg and Wilson, "Introduction," 5.)

${ }^{18}$ Even nowadays the former (and current) president Vladimir Putin has received support from the Orthodox Church, despite even his repression of democracy. (Adrian Blomfield, "Orthodox Church Unholy Alliance with Putin,” http://www.telegraph.co.uk/news/worldnews/1579638/Orthodox-Church-unholy-alliance-with-

Putin.html (accessed May 14, 2012). The trial of the three members of the Pussy Riot punk band is the most recent example of the close ties between the state and the Russian Orthodox Church.

${ }^{19}$ Also, some church members being KGB agents (Keith Armes, "Chekists in Cassocks: The Orthodox Church and the KGB," http://www.gwu.edu/ ieresgwu/assets/docs/demokratizatsiya\%20archive/01-04_armes.pdf (accessed May 14, 2012).

${ }^{20}$ Steinberg and Wilson, "Introduction," 18.

${ }^{21}$ Harold J. Berman, Faith and Order: The Reconciliation of Law and Religion (Grand Rapids, Mich.: W.B. Eerdmans Pub. Co., 2000), 356.
} 
the influence of the religious sacred in social and political life. It can be argued that Communism itself was religious in its utopian and millenarian character. ${ }^{22}$

Most researchers note such similarities between the totalitarian regimes and religion: unified thinking and behaviour, the control of private and social life, the claim to save all of humanity, the person's required loyalty to the (political) ideology, the figures of the saints and sinners, rituals, feasts, taboos, sacred texts, sacred spaces, and the pretension to create the heaven on earth. The founding leader of the Communist party was glorified and treated as a saint, with his 'shrine' in Red Square. ${ }^{23}$ Lenin was "not just one among endless Soviet symbols, but a central organizing principle of authoritative discourse, its master signifier and external canon through which all other symbols and concepts were legitimized." 24 Atheist practices and rituals were set up in the manner of religious rituals. ${ }^{25}$ Thus the ritualistic memory was kept alive. Some scholars name this phenomenon 'civil religion', 'counterreligion', or 'counterfaith'. ${ }^{26}$ In the frames of this research it can be also named the atheist sacred. It was constructed in the same way as the religious sacred, including the use of rituals, calendrical festivals, a figure of the prophet, and an attempt to create a community united by the shared beliefs.

This all is very well described in the following paragraph:

"Recognizing the powerful effects of ritual and sacred symbols, the Communist state, beginning in the early 1920s, developed its own set of emotionally resonant symbols and practices. Revolutionary calendrical festivals were designed to compete with religious ones. Workers' clubs were treated as civic temples that could nurture a healthy and satisfying godless spiritual life. Public life was filled with unceasing moralistic didacticism and language evoking themes of sacred values and goals, redemption, and even resurrection. There were also efforts to create a new socialist community through public rituals of common faith and emotion, including a devotional cult of Vladimir Lenin as saint, apostle, and prophet of the new faith and its new moral and spiritual community."27

\footnotetext{
${ }^{22}$ Engelstein, "Paradigms, Pathologies and Other Clues to Russian Spiritual Culture," 869.

${ }^{23}$ Alexei Yurchak presents Lyuba's (of one of the Soviet students) experience: "In school I drew pretty well and always received good grades in art class. Once for the drawing exhibition devoted to the anniversary of the pioneer organization, I drew a portrait of Lenin in a red pioneer scarf. I wanted to display my picture, but to my surprise our art teacher told me: 'I am going to give you a good grade, but you shouldn't display this picture at the exhibition. And don't show it to anyone. Only the best artists can draw Lenin; he should be drawn well."' (Yurchak, Everything Was Forever, Until it Was No More, 89.)

${ }^{24}$ Ibid.

${ }^{25}$ For example, from the 1960s to 1980s the majority of Soviet people had to participate in May Day and Revolution Day parades. They had to walk across the central square in front of the city's party (spiritual) leaders, who stood on a platform and waved to the masses (believers).

${ }^{26}$ The term 'civil religion' was coined by Robert Bellah. See his Varieties of Civil Religion (San Francisco: Harper\&Row, 1980).

${ }^{27}$ Steinberg and Wilson, "Introduction," 5-6.
} 
Harold J. Berman argues that despite the severe efforts to suppress Christianity, millions of Russians still attended church services although they were subject to punishments. $^{28}$ This can be regarded not only as an expression of piety, but also as a form of resistance. Nationalist movements expressed the need for an ethno-national identity, and religion was an inseparable part of it. ${ }^{29}$ In other words, religion was an important element of the Russian mentality and identity.

Public and private belief systems differed. Many people, being officially Communists, still found a place for religion or spirituality in their private lives. Religious practices still existed in the private sphere. Despite restrictions, punishments, promotion of scientific thought, and the atheist sacred, religion did not cease to exist. The recognition of this fact eventually resulted in a greater official tolerance of religious life. ${ }^{30}$

In summary, religion in the Soviet Union was not only a means for preserving national identity, but also an alternative for those resisting the regime. All these factors are intertwined, but together they laid the basis of what became the religious and spiritual revival in the late 1980s to early 1990s. Interestingly enough, Mikhail Gorbachev came to power in 1985 mentioning the spiritual crisis in the Soviet Union. ${ }^{31}$

\section{Tendencies of Faith in Post-Soviet Time}

The religious and spiritual renaissance in the post-Soviet years is not surprising, bearing in mind that religion still remained an important element in people's life. ${ }^{32}$ As Jarrett Zigon says:

"The truth of the matter, however, is that this was not an instant resurrection of religious faith and practice, for religion had remained central in many people's lives, sometimes publicly but more often privately, throughout the Soviet era. It is not unfair to say, then, that perestroika and the post-Soviet period simply made possible the public expression of what for many had already been there in the form of private belief or curiosity.",33

\footnotetext{
${ }^{28}$ The situation got worse for the Orthodox Church in the early 1960s. During the anti-religious campaign of Khrushchev 10,000 Russian Orthodox Churches were closed. (Berman, Faith and Order, 358.)

${ }^{29}$ Steinberg and Wilson, "Introduction," 2.

${ }^{30}$ Ibid., 6-7.

${ }^{31}$ Ibid., 6.

${ }^{32}$ This resurgence of religion was surprising for many scholars because "they had come to think of socialist societies as thoroughly secular, if not atheist." (Ibid., 1.)

${ }^{33}$ Zigon, Making the New Post-Soviet Person, 10.
} 
There are several reasons for the resurgence of religion in post-Soviet time. First, there was a need to (re)build the Russian national identity. ${ }^{34}$ People had to find a definition for themselves and to feel a sense of belonging to a certain ethnic, religious or social group. Second, people also had to fill the void which opened up after the collapse of the previous belief system. However, such an enthusiastic switch to religion proves that the Communist ideology was never deeply rooted.

According to Mikhail Epstein, post-Soviet Russia faced three main tendencies. ${ }^{35}$ The first was the religious revival of the traditional religions - Orthodox Christian, Catholicism, Islam, Buddhism, and Judaism. The second was an attempt to restore the archaic religious traditions (a kind of a new paganism) and an engagement in the variety of the new religious movements and New Age beliefs - parapsychology, spiritism, etc. ${ }^{36}$ The third tendency was what Epstein named "minimal religion."

Epstein was correct about the first tendency. The 1990s saw the flourishing and increasing trust in the Orthodox Church. ${ }^{37}$ According to the surveys, religiosity in Russia rose from 25 percent in 1988 to 34 percent in 1991 and 47 percent in 1996, and then stabilised. ${ }^{38}$ This growth, as the author argues further, has been caused first by the institutional and cultural revitalisation of the Orthodox Christianity, but also by Protestantism (in the form of evangelical sects), Catholicism, Islam, and the new religious movements. However, the primary overwhelming feeling of freedom ${ }^{39}$ faded away. The number of members of the Orthodox Church stopped growing. Only those who could be called faithful believers remained. For the rest, as Jarrett Zigon says:

\footnotetext{
${ }^{34}$ As Jarrett Zigon argues, "Today Russian Orthodoxy is so closely associated with Russianness that the vast majority of those Russians who are in no way active within the Church consider themselves Orthodox by the very fact of being Russian." (Ibid.) However, he also takes into account that post-Soviet time simply made public that what for many had already been there in the form of a private belief.

35 Mikhail Epstein, "Post-Atheism: From Apophatic Theology to 'Minimal Religion'," in Russian Postmodernism: New Perspectives on Post-Soviet Culture, ed. Mikhail Epstein, Alexander Genis, and Slobodanka Vladiv-Glover (New York: Berghahn Books, 1999), 380-382.

${ }^{36}$ More about new religions in Russia: Shterin, Marat. "New Religions in the New Russia." In New Religious Movements in the Twenty-First Century: Legal, Political, and Social Challenges in Global Perspective, ed. Phillip Charles Lucas, and Thomas Robbins, 99-116. New York: Routledge, 2004.

${ }^{37}$ This can be said not only about the Orthodox Church: "Along with it came the public re-emergence of Islam in various parts of Russia, as well as in its neighbors of Central Asia, Judaism in several of the urban centers, Buddhism and shamanism in central and eastern Russia, and the re-emergence and importation of various protestant faiths, as well as innumerable so-called spirituality cults throughout the country." (Zigon, Making the New Post-Soviet Person, 10.) Also see Steinberg and Wilson, "Introduction," 13.

${ }^{38}$ Spohn, "Transformation Process, Modernization Patterns, and Collective Identities," 214.

${ }^{39}$ Speaking of freedom, the condition of religious freedom should also be noted. In 1997 the law of religion guaranteed, within the context of a secular state, "freedom of conscience and religious confession" and "tolerance and respect" for people's beliefs while asserting an implicit hierarchy of faiths by creating two categories dividing traditional religious organisations from non-traditional religious groups. (Steinberg and Wilson, "Introduction," 14-15.) Christianity, Islam, Buddhism, and Judaism were established as traditional faiths, with the unique position of Orthodoxy.
} 
"Religion either became a non-factor in their lives, if it had ever mattered in the first place, or it became more akin to the kind of private belief and occasionally publicly practiced variety that now characterizes a good deal of religious life in western Europe and North America." 40

The second tendency also coincides with the main tendencies of (late) Russian postmodernity, and in general with the similar trends in the Western world. It can be described as first and foremost the turn from the collectivist to the individualist viewpoint. Increasing individualism brought about the personal search for god and the sacred, hence various new religious movements and New Age practices emerged in the post-Soviet milieu. New Agers believed that people should master their own spiritual paths and transform themselves into conscious human beings, thus achieving personal spiritual self-development and evolution. An increasing spiritual market offered astrology, fortune-telling, tarot cards, healing crystals, balancing of the chakras, aromatherapy, etc. ${ }^{41}$ This popularity of the new spiritualities came as a reaction to the long isolation and also showed the inability of the Orthodox Church to provide all the answers people craved for.

The third tendency, 'minimal religion', might be subject to the further criticism. Epstein defines it as a phenomenon of the post-atheist religiosity and argues that Soviet atheism produced a believer who is difficult, if not impossible, to identify: "he is simply a believer, veruiushchii. ${ }^{42}$ According to him, minimal (or poor, as he defines it) religion is a qualitatively new, post-atheist kind of spirituality in post-Soviet Russia. It is religion as such, religion without further definitions. That is how Epstein further describes this phenomenon:

"It is only in this disparity between faith and beliefs that the poor religion emerges. It is a religion which has no service regulations, no holy books, no specific rituals nor doctrines. It is notable that many more people are now abandoning atheism than joining different denominations. These people can be characterized as 'poor believers' who do not subscribe to any specific set of conventional religious practices." 43

\footnotetext{
${ }^{40}$ Zigon, Making the New Post-Soviet Person, 11.

41 An unforgettable 'made in Russia' phenomenon was the controversial psychotherapist and psychic healer Anatoly Kashpirovsky, who claimed that he can cure people while being on TV.

${ }^{42}$ Mikhail Epstein, “'Post-' and Beyond,” The Slavic and East European Journal 39, no. 3 (1995): 363.

${ }^{43}$ Ibid. More about the minimal religion see Mikhail Epstein, "Minimal Religion," and "Post-Atheism: From Apophatic Theology to 'Minimal Religion',' in Russian Postmodernism: New Perspectives on Post-Soviet Culture, ed. Mikhail Epstein, Alexander Genis, and Slobodanka Vladiv-Glover (New York: Berghahn Books, 1999).
} 
People can neither return to the traditional forms of religiosity (because they now seem too narrow), nor stay with atheism. They try to transcend the boundaries of the traditional denominations and establish a sacred space across the boundaries. This religion, according to Epstein, "has almost no concrete forms of expression, but it participates in almost everything, providing a meaningful tension to our weakened, ignominious lives.",44 With this phenomenon, as he argues further, Russia approaches "a new, post-postmodernist perspective, partly anticipated by its tragic experience of 'darkness upon the face of the deep', "45

Epstein correctly described the essence of this phenomenon, but his naming it 'religion', be it 'minimal', or 'poor', is arguable. First, such adjectives as minimal or poor add a certain value criteria, as if this newly discovered form of religiosity was worse than the traditional one. Secondly, the use of the term religion here only shows Epstein's JudaeoChristian approach, which is in itself reductionist. Thirdly, the boundaries of minimal religion as defined by Epstein are unclear: how to separate this particular tendency from the New Age inspired beliefs which do not require a lot of involvement? Due to these flaws, this research does not use Epstein's suggested term. Here this phenomenon can be regarded as yet another expression of the search for a personal, individualistic sacred; a tendency that permeates the first two tendencies as well. This need for a new, personal (liminal) sacred is born of the liminal post-Soviet ground. The fourth chapter uses the term 'new spirituality', which might be a better name for this Epstein's third tendency. As this new spirituality and new sacred is no longer associated with only religious worlds, the next section looks at the other spheres of post-Soviet life, including the emerging consumer culture, the new media, and generally the changing mentality in that seemingly never ending state of 'in-between'.

\subsection{Liminal Identities}

The second chapter provided a brief glimpse into the term 'liminality'. The fourth chapter will further explore the modes of liminality in post-Soviet literature. Meanwhile, this section attempts to define the liminal identities of the post-Soviet person living in the changing world. This person has also been described as "lost in this world, one who tries to

\footnotetext{
${ }^{44}$ Epstein, "Minimal Religion," 166.

${ }^{45}$ Epstein, "'Post'- and Beyond," 365.
} 
find his self and who, despite the constant failure to accomplish this, has not lost his faith. Because this faith is the only thing he has; he is totally naked - spiritually, materially and nationally." ${ }^{46}$ This description is accurate: being in a liminal state is indeed being 'naked', in a literal or metaphorical sense of the word. As already mentioned in this chapter, this person has yet to invent and construct their Russianness, to define their identity, to deal with the burden of the Soviet past, and to build the bridges for the transition to the future.

Serguei Oushakine provides a typical response of 15 to 22-year-old Russians attempting to describe their understanding of national identity: "Post-Soviet people - the ones who have not become new Russians but who are not Soviet anymore. They are the main part of the Russian population - dreaming about old times while knowing that there would be no return of the past." ${ }^{47}$ It is not by accident that this in-betweenness will constitute a code word in this research, as the notion of being 'in-between' permeates Pelevin's prose, and he as a writer is hugely influenced by the changes that took place in his country.

It is difficult to avoid generalisation when speaking of the post-Soviet mentality. There are at least two generations involved, and both have different world-views. Jarret Zigon classifies the nation into people who went along with the transformation process and nationalists who still long for the Soviet past. ${ }^{48}$ The young generation was keen to transform into new "post-Soviet persons". 49 The old generation that had spent their whole life in the Soviet state suddenly felt useless. The official ideology - the old sacred - was no longer valid. This generation felt abandoned and longed for their Soviet past when everything seemed eternal and secure. Some of them named the Soviet times as the best times they or their parents had ever experienced. The system gave them jobs and provided them with some sort of financial security; now this was lost.

However, what both of these groups share is the experience of the Soviet Union as an isolated system in a political and economic sense, and the experience of a liminal period of radical changes. This isolation was crucial first and foremost for political reasons, as capitalism was considered to be the main enemy. It continued throughout most of the $20^{\text {th }}$

\footnotetext{
${ }^{46}$ This is an opinion of a student who was asked about the true nature of the post-Soviet identity. (Serguei Oushakine, "In the State of Post-Soviet Aphasia: Symbolic Development in Contemporary Russia," EuropeAsian Studies 52, no. 6 (2000): 996.)

${ }^{47}$ Based on the data collected in Barnaul, Siberia, mostly in 1997. (Ibid., 995.) As the author notes further, the answers indicate a feeling of being caught in-between: "between two classes (poor/rich), between two times (past/future), between two systems (Soviet/non-Soviet).” (Ibid.)

${ }^{48}$ Zigon, Making the New Post-Soviet Person, 7. This longing can also be a mix of the longing for real life experiences and for the so-called 'imaginary past', created by Soviet leaders who deliberately rewrote the history of the nation. More about that 'imaginary past' in Neidhart, Russia's Carnival, 2002.

${ }^{49}$ Zigon, Making the New Post-Soviet Person, 12.
} 
century and had a huge impact on the cultural life and the mentality of the Soviet people, shaping their identities. Ironically, despite being repressive, the Soviet system can be also seen as a comfort zone. Everything was planned, everything was communal, and people just had to blindly obey the rules of the system. The party and the state were responsible (and guilty too) for everything. As Richard Sakwa noticed, people had no personal responsibility, developing a certain infantilism. ${ }^{50}$ If the Soviet times can be regarded as childhood and an infantile state, then post-Soviet times embody the liminal teenage years and growing up.

The Soviet state presented itself as a clear structure. After its break-up this highly standardised life and structure was changed by anti-structure, fragmentation, uncertainty, and disorder - all common for the liminal stage. The newly gained freedom brought the need for people to take responsibility for their own lives and to make independent decisions, and for most of them this task proved to be too difficult. ${ }^{51}$

Facing this identity crisis, people started redefining themselves and their Russianness. This was even more difficult because, as Julie A. Buckler points out, the notion of Russianness was always fissured. ${ }^{52}$ As Jarrett Zigon notes:

"No matter the response to the post-Soviet transformations, it is clear that identity, both personal and national, can no longer be conceived in terms of an essential Russianness. Even those who have responded to these transformations with nationalist zeal cannot help but do so through hybridized categories such as sovereign democracy and Russian style capitalism.",53

This isolation was replaced with a relative openness to the world, the collectivism turned to individualism, and the traditional notions of Russian culture as suffering ${ }^{54}$ and Russian soul (dusha) was overtaken over by the Westernisation and the new consumerism. Svetlana Boym provides an illustrative example of such a shift of sacrality, recalling that in 1993 the notorious joint stock company MMM invaded "a sacred Soviet space" by renting the third floor of the Lenin Museum on Red Square (where the largest map of the Soviet

\footnotetext{
${ }^{50}$ Moreover, "the relatively cheap housing, energy and transport, the almost free telephones for local calls, the subsidised crèches and nurseries and holidays, the stable irrationality of the economic system and the strongly ordered social and cultural life, all provided a relatively congenial environment for the citizens of late communism - as long as they kept their mouths shut in public." (Richard Sakwa, Russian Politics and Society (London: Routledge, 2002), 359.)

51 "The post-Soviet Russians have to shape their futures themselves. People who until recently were barred from any major decision-making suddenly had to design their own lives. A society whose future had been monopolized by one institution is now being turned into a decentralized society in which millions of individuals make independent choices, as in any free market of goods and ideas." (Neidhart, Russia's Carnival, 12.)

${ }_{52}$ Julie A. Buckler, "What Comes After 'Post-Soviet' in Russian Studies?” PMLA 124, no. 1 (2009): 254.

${ }^{53}$ Zigon, Making the New Post-Soviet Person, 7.

${ }^{54}$ More about the notion of suffering - in the fifth chapter, section 5.1.
} 
Union was kept). ${ }^{55}$ This fact definitely marks the emergence of the new 'monetary sacred', which symbolically replaced Communist ideology. ${ }^{56}$ Post-Soviet society entered into an age of consumer paradise, which for most Russians was beyond their reach. The gap between the nouveaux riches and those struggling to survive widened. ${ }^{57}$ Living in a period of radical changes, exposure to the influence of the West, transition to a market economy, and the above noted personal freedom shaped the attitude of people, hungry for Western goods. As Slobodanka M. Vladiv-Glover notes, Russia adopted extreme features of Western consumerism without being able to reduce its soul-destroying influences. ${ }^{58}$

Billboards and logos replaced the party slogans in the gray post-Soviet cities. Standardised modest lives were shaken by the new consumer culture. The infamous phrase 'there is no sex in our country' was replaced by excessive sexual images in the media. Drugs were rapidly replacing alcohol, with marijuana as the most popular while heroin became the second. ${ }^{59}$ The image of women in post-Soviet society became over-sexualised. Such overtly shown sexuality as well as a 'moral degradation' was associated with the impact of the West. ${ }^{60}$ Zigon goes even further noting that sex became a symbol of Russia and its lost moral compass. $^{61}$

However, after this period of anti-structure, society had to enter a new stage of renewed structure. For Russia, this time of being in-between seemed to stand still. The process of 'finding oneself' took longer than it could have been anticipated. As it was already mentioned, for some people the idea of freedom, instead of a liberating force, had become a curse. This tragic outcome of the idea of freedom is eloquently expressed in the following quote by Susan Richards:

"'You in the West were our dream,' Natasha went on, hitting her stride, the Siberian Cassandra. Her wild curls stood up and her pale face shone. 'And when it collapsed,

\footnotetext{
${ }^{55}$ Boym, Common Places, 272.

56 The discussion on the monetary sacred will be continued in the seventh chapter, section 7.3.

${ }^{57}$ Mark Lipovetsky explores the concept of the so-called New Russians in: Lipovetsky, Mark. "New Russians as a Cultural Myth." Russian Review 62, no. 1 (2003): 54-71.

${ }^{58}$ Vladiv-Glover, "From Bread Dolls to Prostitutes," 90.

${ }^{59}$ Jarrett Zigon notes that at the time of his writing (2004) it is estimated that Russia has four million active drug users, one of the highest percentage of drug users in the world. (Zigon, Making the New Post-Soviet Person, 13.)

${ }^{60}$ However, this is definitely not the only one possible interpretation. For example, "the new pornography in Russia can be seen not simply as a reaction to the demise of censorship, but as a response to the constantly shifting boundaries - no less in the new Russia than in the old - between what counts as 'public' and 'private', particularly in the sphere of ownership of one's body, formerly part of the communality of Soviet life." (Adele Marie Barker, "The Culture Factory: Theorizing the Popular in the Old and New Russia," in Consuming Russia: Popular Culture, Sex, and Society since Gorbachev, ed. Adele Marie Barker (Durham: Duke University Press, 1999), 34.)

${ }^{61}$ Zigon, Making the New Post-Soviet Person, 13.
} 
we blamed you. You weren't to blame. We just had no idea how to be free. We were like those prisoners who refuse to leave because they've nowhere else to go. However hard you try you'll never really understand what it was like to live in a country that was one great concentration camp. I'm not using the word loosely. It's no reflection on your intelligence or empathy. It's just that you were born free.

When the Soviet Union fell, the country went through a sort of nervous breakdown. We came here looking for a new beginning. We didn't understand that there are no new beginnings in Russia, only long and terrible endings. We didn't realize that nothing could change until people find themselves.",62

This quote also, at least partially, explains why the notion of freedom is so ambiguous in the Russian mentality. It is both longed for and feared. Freedom can mean responsibility and the unknown, uncertainty and a multitude of choices. "We had no idea how to be free," this is also one of the questions that Victor Pelevin explores in his prose. What does it mean to be entirely free? Is it possible to escape from the Soviet world, from the post-Soviet world, from this world, from oneself? Pelevin's need to ask these questions, as the next chapters will demonstrate, emphasises the importance of this notion. These chapters will also show how in Pelevin's prose the notion of freedom is constructed as a sacred category, resembling the Buddhist notion of liberation.

Richards' quote also expresses that deep abyss between the Western and (post) Soviet world, and the impossibility to adequately 'translate' one's experiences. In this sense, a huge part of the meaning in Pelevin's books is also lost in translation.

The ambiguity of freedom can also be explained with the phenomenon of nostalgia. ${ }^{63}$ As Rosalind Marsh notes:

"Russian literature reflects the main intellectual trends of the age - if under perestroika Russians were eager to discover the truth about the past and were receptive to calls for 'repentance', in the post-Soviet period men were eager to forget past traumas and escape from the harsh present into dreams of happier times.",64

\footnotetext{
${ }^{62}$ Richards, Lost and Found in Russia, 77.

63 "In the past two to three decades the term has been expanded, and it also has been heavily theorized (mostly critically and negatively for what has been seen as its inherent conservatism and distance from real history). It has been linked to memory, history, affect; it has been attached to political allegiances and models of consumerism; it has been variously approached as a form of psychological whiplash, a cultural style, the abdication of memory, an aesthetic treatment, an ornament, a technique, a part of the narrative of history, or a part of the narrative of critical theory." (Maria Todorova, "From Utopia to Propaganda and Back," in PostCommunist Nostalgia, ed. Maria Todorova and Zsuzsa Gille (New York: Berghahn Books, 2010), 3.)

${ }^{64}$ Rosalind Marsh, Literature, History and Identity in Post-Soviet Russia, 1991-2006 (Bern: Peter Lang, 2007), 166-167.
} 
Svetlana Boym described the nostalgia as a longing for home that exists no more or might have never existed. ${ }^{65}$ The communist past, as the time of childhood, is treated as heaven lost forever. Nostalgia is born in that feeling of emptiness and the overall chaos of life without clear boundaries. ${ }^{66}$

This in-between zone of disorder, silence, and anti-structure; in other words, the liminal zone, opens up the possibility to speak of the sacred in post-Soviet literature. In this sphere the search for the sacred can be and is actualised. The aim of this research is to examine the formation of the 'new post-Soviet sacred', and the process of reinventing the sacred without narrowing it down to only religious aspects. As emphasised in the first chapter, the sacred here is regarded as a relative and temporary phenomenon, which is constructed through certain cultural practices and traditions and helps us disclose the concepts of meaning, identity and community through individual reactions, perceptions and behaviour directed to the objects which are perceived as sacred. Otherwise, without such a definition, hardly anyone could speak of the sacred in a seemingly secular post-Soviet milieu. The next section provides a general overview of post-Soviet literature in the early 1990s and its major shifts. It explores how the literary situation reflects the general atmosphere of inbetweenness that this chapter attempts to demonstrate.

\subsection{Russian Tradition: Literature as Religion}

"The only real Russian literary tradition is to write good books in a way nobody did before." 67

As it was discussed, post-Soviet literature reflects the condition of post-Soviet society in general, the in-between zone of the new beginnings and terrible endings. In this zone, as Natalia Ivanova correctly notes, "many people felt like sudden foreigners at home."68 PostSoviet literature is hard to define and to frame because of its wide diversity. Russian writers not only had to deal with the Soviet legacy, with the 70 years of cultural isolation (the link

\footnotetext{
${ }^{65}$ Ibid., 167. Svetlana Boym also discusses two types of nostalgia: the first one, the utopian, emphasises the rebuilding that 'Russia that we lost', and the second one emphasises the feeling of longing, not the referent itself. (Boym, Common Places, 151.)

${ }^{66}$ The sixth chapter will discuss how alcohol can be linked with the notion of nostalgia in Pelevin's prose.

${ }^{67}$ Leo Kropywiansky, interview with Victor Pelevin, http://bombsite.com/issues/79/articles/2481 (accessed December 20, 2010).

${ }^{68}$ Natal'ia Ivanova, "Afterward: Post-Soviet Literature in Search of a New Identity," Russian Social Science Review 39, no. 4 (1998): 76.
} 
with Soviet literature is inevitable - it can be parodied or stylised, but not forgotten), but also create new directions in fiction, coming back to pre-Soviet literature, evaluating Soviet years and acquainting themselves with Western trends. Roman Ivashkiv also notes that Soviet repressions interrupted the natural development of Russian literature. Thus during the postSoviet period writers were confronted with an aesthetic void. ${ }^{69}$ As he argues further, the writers "were obliged to bridge the gap between the pre-Soviet literary tradition and the present-day, postmodern context. But because the modernist tradition in both countries [Russia and Ukraine] had been stifled to a large extent, postmodern literature could not develop in response to modernism as it did in the West." ${ }^{, 70}$ Although writers no longer had to struggle against the regime, they had to deal with a new situation in post-Soviet society - the birth of a consumer culture and the upcoming economic difficulties. They had to create a new language that could express the enormous changes that took place during the post-Soviet years.

Russian literature has always been more than just a depiction of reality in the works of prose, poetry, or essays: it has also tried to transform that reality. As Lyudmila Petrushevskaya once said, "Russian literature has been a kind of religion in this country - a religion based on the moral position of writers, on their suffering. All our greatest writers have been sufferers and saints." ${ }^{, 71}$ Svetlana Boym also emphasises this function of literature, claiming that in Russia literature served not only for educational purposes, but was a guide to life, "a sort of nineteenth-century liberation theology":

"What distinguishes Russians is not so much what they read but how they read - by passionately transgressing the boundaries between life and fiction, by wishing to live out literature and with its help change the world."

It is hard to disagree with this statement, as the notion of suffering has a long history in Russian literature and in the overall mentality of the Russian people. Svetlana Boym also argues that "after the nineteenth century, Russian literature became a form of civic

\footnotetext{
${ }^{69}$ Roman Ivashkiv, "Postmodern Approaches to Representation of Reality in Ukrainian and Russian Literatures: The Prose of Yuri Andrukhovych and Viktor Pelevin," Journal of Ukrainian Studies 32, no. 1 (2007): 37.

${ }^{70}$ Ibid., 38.

${ }^{71}$ Alexandra Schwartz, "Sometimes a Small Redemption: On Ludmilla Petrushevskaya," http://www.thenation.com/article/sometimes-small-redemption-ludmilla-petrushevskaya (accessed December 20, 2010).

72 Boym, "From the Russian Soul to Post-Communist Nostalgia," 139-140. This statement is especially applicable speaking about Pelevin's works, where irony and sarcasm hide the passionate aim to transgress the boundaries between the written text and reality, to explain and to frame that reality, at the same time painfully realising that such explanations are not possible.
} 
religion., ${ }^{, 73}$ Of course, 'religion' here is a metaphor, emphasising and strengthening the moral and spiritual importance of literature. As Osip Mandelshtam, one of the leading Russian poets of the $20^{\text {th }}$ century, said just a few years before his death in the labour camps: "Only in Russia is poetry respected; nowhere else do people get killed because of it." 74

Andrew Wachtel goes so far as to claim that a possible cultural definition of Eastern Europe is, "that part of the world where serious literature and those who produce it have traditionally been overvalued." 75 Also, he notes that, "the majority of East European countries were in substantial measure invented by writers. Literature here, far from being a reflection of reality, was very frequently a creator of new identities and new social and political realities." 76

\section{Russian Literature: No Longer a Sacred Mission?}

As mentioned, Russian literature had always taken the privilege to discuss the 'eternal' questions of meaning and life. During the Soviet years literature was used as an ideological weapon declaring the ultimate truths about the victory of Communism and the bright future (except underground, or samizdat literature). Writers in the Soviet Union had to create a new consciousness for the new 'Soviet person' and to support the construction of the new Soviet sacred. For the construction of the political ideology as a form of the civil religion, religious vocabulary was often used. The purpose of socialist realism, a dominant style in the Soviet Union, was to help achieve the goals of Communism and socialism. As Katerina Clark notes, the basis of most socialist realism works was mythic stories, and the rulers embodied a higher power. ${ }^{77}$ However, this position changed during the $1990 \mathrm{~s}$ :

"Before the fall of the Soviet Union, literature guaranteed a sure connection to eternity; it endowed the life of the Russian intelligentsia with meaning. By contrast, during the 1990s literature no longer provided a connection to anything but a publisher's profit or loss. The intelligentsia thus was left without the basic element of its identity." 78

\footnotetext{
${ }^{73}$ Svetlana Boym, The Future of Nostalgia (New York: Basic Books, 2001), 257.

74 Barry P. Scherr, “After Perestroika: Era of Rasstroika," South Central Review 12, no. $3 / 4$ (1995): 159. However, as Scherr concludes, during the post-Soviet years "the writer's word is no longer sacred in the same way." (Ibid.)

75 Andrew Baruch Wachtel, Remaining Relevant After Communism: The Role of the Writer in Eastern Europe (Chicago: University of Chicago Press, 2006), 4.

${ }^{76}$ Ibid., 12.

${ }^{77}$ Katerina Clark, The Soviet Novel: History as Ritual (Bloomington: Indiana University Press, 2000), 191.

${ }^{78}$ Lyudmila Parts. "Degradation of the Word or the Adventures of an Intelligent in Viktor Pelevin's Generation P," Canadian Slavonic Papers 46, no. 3/4 (2004): 444.
} 
In other words, literature lost its elevated status. During the post-Soviet years a new attitude towards literature emerged. Literature was no longer held in special esteem. As Shneidman puts it:

"Great nineteenth-century Russian novels are remembered not only for their style, structure, and imagery, but also for the depth of the ideas expressed and explored in them, and the sincerity and commitment of their authors. Today, most authors are indifferent, if not heartless, observers of the difficult life in contemporary Russia. Modern Russian literature informs and may even entertain the reader, but as opposed to classical Russian literature, it does not teach, inspire, or heal.",79

Not only has the attitude towards the writers and literature changed. Being a writer was no longer a profession that could guarantee a stable income, as it has been in the Soviet years. ${ }^{80}$ Most writers were confronted with the choice of either writing commercially successful works, or writing what they wanted and getting a day job. Some of them stopped writing or emigrated. ${ }^{81}$ Some adapted and started writing commercially successful works. ${ }^{82} \mathrm{~A}$ group of writers expressed their concerns in 1992, pointing out that "the old scourge of political censorship was now being replaced by economic censorship, which posed a new threat to writers' freedom." 83

As N.N. Shneidman notes, the Soviet era faced two streams in literature: official Soviet, and underground (samizdat) literature. After the break-up of the Soviet Union two ideological literary streams emerged. One was liberal and conservative, the other patriotic. ${ }^{84}$ Shneidman notes that many writers of the older generation continued to write and publish their texts, but they were quite mediocre compared, say, to their earlier works. ${ }^{85}$ There were also others who either stopped writing or turned to politics or other activities, for example, Vasily Belov and Valentin Rasputin. Writers from the older generations also found it harder to welcome the changes. Thus, according to Shneidman:

\footnotetext{
79 N.N. Shneidman, Russian Literature, 1995-2002: On the Threshold of the New Millenium (Toronto: University of Toronto Press, 2004), 15.

${ }^{80}$ In the novel Generation $P$ Pelevin illustrates this change portraying Tatarsky - a former poet who turned to the advertising business.

${ }^{81}$ For example, a prominent Russian writer Tatyana Tolstaya is dividing her time between Russia and the United States. Dina Rubina lives in Israel, but writes in Russian.

${ }^{82}$ A very successful genre proved to be detective stories, thrillers, and science fiction, with authors such as Alexandra Marinina, Polina Dashkova, Darya Dontsova, Sergey Lukyanenko and others.

${ }^{83}$ Scherr, "After Perestroika: Era of Rasstroika," 158.

${ }^{84}$ Shneidman, Russian Literature, 1995-2002, 5.

85 Shneidman puts Viacheslav Pietsukh, Anatolii Gavrilov, Valeriia Narbikova, and Andrei Korolev as examples. (Ibid., 11.)
} 
"Most literature published in Russia today is written by those who are in their thirties, forties, and early fifties and who entered the literary scene during the years of perestroika and in the post-Soviet era. Mikhail Butov, Oleg Ermakov, Aleksandr Ivanchenko, Aleksandr Kabakov, Sergei Kaledin, Valeriia Narbikova, Marina Palei, Viktor Pelevin, Viacheslav Pietsukh, Irina Polianskaia, Nina Sadur, Mikhail Shishkin, Aleksei Slapovskii, Vladimir Sorokin, Aleksandr Terekhov, Tatiana Tolstaia, Liudmila Ulitskaia, among others, emerged on the scene in the decade between 1985 and 1995." 86

However, Shneidman also notes that although the new authors broadened the span of Russian literature, quantity does not always mean quality. Some authors lacked proper training, which affected the style and language as well. He even claims that, "the novel in Russia is no longer a carefully constructed artistic edifice, but rather a haphazard collage, written, in most instances, in poor literary Russian and littered with slang and foreign words. The structure of this novel is loose, and there is seldom psychological exploration of the reasons which motivate human action., 87

In other words, literature no longer 'inspired' or 'healed'. Moreover, it was no longer paid its due respect, both from readers and from writers. Literature as 'sacred' became yet another form of popular culture and thus 'profanised'. Some critics complain that this socalled 'profanity' now dictates the new trends in literature, and claim that Pelevin's prose is an example of its profanisation. ${ }^{88}$ Literature began to be dominated not by collectivism, but by individualism. 'Eternal' questions were replaced by a focus towards the human being. Some critics, including Shneidman, make pessimistic conclusions regarding such a switch to individualism, which also reflects the emergence of the 'monetary sacred':

"Historically, Russian literature has reflected social processes more than any other foreign literature. ... Now that literature is no longer a tool of ideology, it is free to explore and reflect the human psyche, and the emotions and passions of the individuals portrayed. Unfortunately, this is not happening in contemporary Russian literature, and public taste is no longer determined by the reading public. Instead, in order to make up for the artistic shortcomings in current prose, public taste is manipulated by publishers and booksellers. With the help of advertisements and promotions they dictate, up to a point, the public need, and writers are often forced to comply. For a manuscript to be accepted for publication a liberal writer is required to produce a gripping story in which there is an inventive and fascinating plot, and a mixture of politics, sex, scandal, insolence, and some mystery." 89

\footnotetext{
${ }^{86}$ Ibid., 12.

${ }^{87}$ Ibid., $12-13$.

${ }^{88}$ More about the two camps of literary critics, discussing Pelevin's works - in the fourth chapter.

${ }^{89}$ Ibid., 15-16.
} 
However, this research would argue that such a turn in literature is not 'profanisation', but an emergence of a different kind of the new sacred, which reflects the same tendencies of society in general. An obsession with politics, sex, scandal and money just reflects the emerging new tendencies of meaning, identity and community - all which will be discussed in the subsequent chapters.

Alexander Genis claims that during the transitional period, "Soviet-Russian literature lost both of its distinguishing features, ceasing to be either Russian or Soviet." 90 It can be argued that Russian literature is in a sense homeless: literature still searching for its identity and place, thus reflecting Soviet society itself. Post-Soviet literature reflects the mode of this period of in-betweenness and unstable values which, as mentioned, can be defined by Victor Turner's notion of liminality. Russianness as part of an identity and Russianness in literature were yet to be defined.

The problem of the lost eternity in post-Soviet years is explicitly expressed in Victor Pelevin's novel Generation P:

"It turned out that eternity only existed as long as Tatarsky sincerely believed in it, and was actually nowhere to be found beyond the bounds of this belief."91

"He realised something else too: the eternity he used to believe in could only exist on state subsidies, or else - which is just the same thing - as something forbidden by the state." 92

Here Pelevin clearly shows that although people in the Soviet times were provided with the illusion of eternity (the already mentioned 'eternal state'), the post-Soviet times no longer guaranteed this illusion. As the Soviet structure was followed with the post-Soviet anti-structure, the same can be said about post-Soviet literature: everything that was previously repressed became the norm. The eternal collective belief system was replaced by a plethora of emerging new 'sacreds', all of which were individual, dynamic, and subject to change. The artificial Soviet optimism was replaced by moments of existential despair.

\section{A frighteningly vague uncertainty dominated everything.}

For Victor Pelevin, this uncertainty and despair resulted in the search for new explanations of the world's structure and its new meaning, permeated with the feeling of

\footnotetext{
${ }^{90}$ Alexander Genis, "Perestroika as a Shift in Literary Paradigm," in Russian Postmodernism: New Perspectives on Post-Soviet Culture, ed. Mikhail Epstein, Alexander Genis, and Slobodanka Vladiv-Glover (New York: Berghahn Books, 1999), 87.

91 Pelevin, Homo Zapiens, 4.

${ }^{92}$ Ibid., 5.
} 
emptiness. The subsequent chapters are dedicated to the discussion on the liminal ambiguity in Pelevin's prose: between the postmodernist irony and a genuine search for the new meanings in the ever changing post-Soviet world. I would argue that post-Soviet literature, and accordingly, Victor Pelevin's works, reflect that enormous longing for the sacred - that is, its previous stability and clarity and, at the same time, the realisation of its relativity and ephemerality. Pelevin's works are a step away from this anti-structure and a step towards a new future and the new structure of post-Soviet literature.

Pelevin, this enfant terrible of contemporary Russian literature, holds a significant position in this literature. He consciously makes an effort 'not to belong' to any existing literary trends. Pelevin's popularity does not come from compromising: he avoids nationalist statements that would be attractive to the older generation, and at the same time his books are not an easy science fiction or detective read that would seduce the young generation. Not only he deconstructs socialist and liberal realism, he also deconstructs the new trends of commercial literature as well, as will be seen in the further literary chapters. Pelevin's prose in a sense transcends and includes the existing literary trajectories, creating an eclectic mix. His playful attitude could be easily mistaken by Russian critics as 'profanisation' of literature. However, due to the above mentioned reasons, the sacred, emerging in his works, is reflected in a more complex and profound way. That is why Pelevin is chosen as representative of post-Soviet literature.

The fourth chapter will further explore why Pelevin can be regarded as an embodiment of this post-Soviet transformation stage, his works being an illustrative example of this transformative experience. However painful to endure, this transformation is a necessary part of the liminal stage of post-Soviet literature and also signifies a ray of hope. As Alexander Genis argues, "the chance of a lifetime was thus offered to Russian culture, a chance that usually comes to a society only after crushing defeat in war: the chance to start from scratch." 93

\subsection{Conclusions}

"Russia cannot be understood with the mind alone," Fyodor Tyutchev exclaimed poetically in the $19^{\text {th }}$ century. It was held to be unstable, superstitious, chaotic, and irrational.

\footnotetext{
93 Genis, "Perestroika as a Shift in Literary Paradigm," 95.
} 
"In Russia, one can only believe," concluded the poet. Do contemporary Russians still believe in the Sacred Russia (Sviataja Rus'), the notion developed throughout the centuries? Further literary chapters will discuss whether homeland and Russianness can be considered as sacred categories in Pelevin's prose. Meanwhile, this chapter dwelled upon the questions of the changing sacred in the liminal post-Soviet zone. These changes themselves can in a sense become sacred, as a perpetual becoming and reinventing of oneself, hence the significance of spiritual searching, so important especially in the early post-Soviet years. The liminal, inbetween situation in post-Soviet Russia encouraged the search for a new sacred and sharpened the desire to find a stable ground, a new identity, meaning and truth. This search could be expressed through: the engagement with both traditional religions and new, exotic spiritualities; monetary excitement; experimentation with the new forms of relationships both social and intimate; the use of mind-altering substances; and looking back and longing for the sacred, forever lost. Those who look back might have become, as Lot's wife, a pillar of salt, as the painful nostalgia would not let them move forward into a future yet unknown.

Thus the main question that was posed in the beginning of this chapter, "what is Russian identity?", can be answered in a seemingly simple manner - it is the deconstructed Soviet identity. It was this identity that needed to be sacrificed in order to start a brand new state and stage of mind. For some people, this sacrifice was too difficult to perform. There was hardly a process of 'de-Sovietisation' in Russia, except that religion (spirituality) played the major role in the purification process from the Soviet identity. This is at least one of the reasons why the concept of Russian identity still remains problematic.

The Soviet past still functions in the lives and minds of Russian people as an inevitable legacy. As Marsh rightly noted, instead of repenting or rejecting the Soviet past, Russians tend to escape from the harsh present into dreams of happier times. ${ }^{94}$ Theoretically, they now live in a free country. Practically, there is still a long road to freedom. Pelevin's works show the ambiguity of the concept of freedom in the post-Soviet mentality.

An inevitable outcome of this post-Soviet situation is a feeling of in-betweenness: an existence between the old system to be destroyed and the new order yet to be created. Out of the world of binaries (oppression and resistance, repression and freedom, culture and counterculture, public self and private self, the truth and lie) people entered the world of mixed values, a fragmented reality, disorder, and uncertainty. Liminality marks a state betwixt and between, in and out, on the threshold, neither here nor there. This post-Soviet

\footnotetext{
${ }^{94}$ Marsh, Literature, History and Identity in Post-Soviet Russia, 166-167.
} 
threshold, as Oushakin states, has a peculiar nature: "it does not provide any clues about the direction to follow, it does not channel one's identificatory process; instead it outlines the paths that should not be taken." 95 The post-Soviet era no longer provided a universal and eternal notion of what is sacred, yet it presented a new challenge to create a new sacred, which at this point might neither be universal nor eternal. The next chapters will further explore this creation of the new sacred(s) ${ }^{96}$ in Pelevin's works.

${ }^{95}$ Oushakine, "In the State of Post-Soviet Aphasia," 995.

${ }^{96}$ The unusual plural form of the noun 'sacred' is meant to highlight this concept's relative and dynamic nature. 


\title{
Chapter 4:
}

\section{Pelevin's Prose: General Features}

\subsection{Victor Pelevin: From the Eternal State to the Eternal Non-Return}

\begin{abstract}
"In order for him to believe sincerely in eternity, others had to share in this belief, because a belief that no one else shares is called schizophrenia."
\end{abstract}

As mentioned in the third chapter, the Soviet Union presented itself as the eternal state. ${ }^{2}$ Pelevin's prose is an eloquent account of this liminal state of people who no longer believe in that eternity and yet seek other stable and shared beliefs.

This chapter presents one of the most prominent contemporary Russian writers, Victor Pelevin, going so far as to consider naming him, albeit conditionally, a sacred figure in the post-Soviet milieu. Analysing the context in which Pelevin is living and writing, that is, the ideology of the new spirituality, this chapter further discusses the role of the deconstructive gesture as seen in Pelevin's texts, and employs the notion of the productive void to his writings. Exploring the roots of that need for deconstruction, it turns back to look at the notion of liminality. This chapter also explores liminality and its importance in Pelevin's works and in the post-Soviet context in general. Finally, through the prism of liminality and beyond, it provides a general introduction to Pelevin's world, discussing the notions of (sacred) space and persons in his prose and how these can help us to further explore the concept of the sacred.

One of the most well-known and best-selling Russian authors, Victor Olegovich Pelevin (1962), ${ }^{3}$ was born in Moscow into the family of a military officer and a state economist. He briefly studied at the Gorky Literary Institute but graduated from the Moscow

\footnotetext{
${ }^{1}$ Pelevin, Homo Zapiens, 4.

${ }^{2}$ Yurchak, Everything Was Forever, Until it Was No More, 1.

${ }^{3}$ Canadian novelist Douglas Coupland, with whom Victor Pelevin is often compared (namely, compared are their books, Coupland's Generation X and Pelevin's Generation P, written eight years later; for this comparison see Sally Dalton-Brown, “The Dialectics of Emptiness: Douglas Coupland's and Victor Pelevin's Tales of Generation X and P," Forum for Modern Language Studies 42, no. 3 (2006): 239-248) was born in 1961. Thus both writers belong to the same generation, although were born and raised in ideologically different worlds.
} 
Institute of Power Engineering and subsequently worked as an advertising copywriter and a journalist for Science and Religion magazine before starting to write full-time. ${ }^{4}$ His first collection of short stories, The Blue Lantern (1991), won the annual Russian Little Booker prize and paved the way for further successful books. His third novel Generation $P$ was made into a movie. ${ }^{5}$ Interestingly enough, Pelevin's works have also gained high popularity in the non-Russian world and were translated into many languages. One could argue that it is tricky for non-Russians to understand his texts because of their multi-layered nature, inter-textuality and multiple references to other Russian authors and the Soviet/post-Soviet culture/counterculture. Indeed, Pelevin creates a world where the boundaries of reality and non-reality, actuality and fantasy, are masterfully erased. As Boris Tuh states, it is not important which of these realities is true. ${ }^{6}$ Mark Lipovetsky claims that Pelevin, "combines the traditions of Soviet science fiction and Zen Buddhist mysticism with the techniques of postmodernist metafiction, and the result is an ambiguous absurd style that is uniquely Pelevin's."7 This statement laconically summarises the main features of his prose.

The critical reviews of this author span a wide range of opinions. Being the author of best-selling books, Pelevin is often regarded as a writer for the masses. The critics who write about him can be conditionally divided into two camps. The first praises his genius, compares him to Vladimir Nabokov or Hermann Hesse, and regards him as one of the best contemporary Russian authors. The second openly doubts whether Pelevin's writings can be called literature at all, claiming that it is no more than "intellectual pops." 8 Also, some Russian critics tend to regard him not as a 'real' writer but more of a publicist. Aleksei Nomad even claims that this author ignores the main functions of 'real' literature, such as education or raising the "main questions."9 Pelevin's novel Buddha's Little Finger was notoriously excluded from consideration for the 1997 Russian Booker Prize. Jury president Igor Shaitanov explained that it showed disrespect for Russia's cultural heritage, and called it

\footnotetext{
${ }^{4}$ Joseph Mozur, "Viktor Pelevin: Post-Sovism, Buddhism, \& Pulp Fiction," World Literature Today 76, no. 2 (2002): 61 .

5 The movie under the same name, directed by Victor Ginzburg, was released in 2011 (starring Vladimir Epifantsev, Mikhail Efremov, Andrei Fomin) and has been well received.

${ }^{6}$ Boris Tuh, Pervaja desiatka sovremennoj russkoj literatury (Oniks 21 vek: Moskva, 2002), 197.

${ }^{7}$ Mark Lipovetsky, quoted from Roman Ivashkiv, "Postmodern Approaches to Representation of Reality in Ukrainian and Russian Literatures: The Prose of Yuri Andrukhovych and Viktor Pelevin," Journal of Ukrainian Studies 32, no. 1 (2007): 60.

${ }^{8}$ Pavel Basinskii, "The Pelevin Syndrome," Russian Studies in Literature 37, no. 3 (2001): 90.

9 Aleksei Nomad, “T.', Viktor Pelevin,” http://www.newslab.ru/review/292551 (accessed June 30, 2011). However, I would strongly disagree with this statement as the educational function in Pelevin's works is evident, although he chooses not the direct, didactical teaching and preaching, but expresses his views employing irony and sarcasm. Also, the so-called 'main questions' pervade all his prose.
} 
"a form of computer virus designed to destroy cultural memory." description would be describing Pelevin as litmus paper of the collective subconscious. ${ }^{11}$ Nomad notes that the newest history of Russia is the history of Pelevin's metaphors, thus emphasising this author's accurate insights into the contemporary Russian mindset. ${ }^{12}$

However, the debate surrounding Pelevin's works only adds to his popularity as well as the urban myths surrounding this author. ${ }^{13}$ Despite the contradictory opinions on his writings, Pelevin is definitely one of the most fascinating writers in contemporary Russia: "His satires take the temperature of post-Soviet Russia, in all its amoral, dystopian chaos."14 There is how Pavel Basinskii explains the popularity of Pelevin's books:

"But, for all this, Pelevin possesses one indubitable gift. He knows how to be contemporary. This, incidentally, is a rare talent in the literary milieu, which is infatuated with old fashions and Chekhov's pince-nez on a string. Moreover, Pelevin is not artificially contemporary. He does not just describe the illnesses of the time, he is ill himself. He does not strive to keep up with the flow; he spreads his wings in it." $" 15$

This multi-layered prose can also be regarded as a compromise between the elite and the popular or commercial literature, representing an eclectic post-Soviet spiritual condition. Pelevin serves as a symbol of the contradictory epoch, combining mass and elite culture, spirituality and commercialism, drawing the maps of this epoch which can sometimes be very funny, and sometimes downright scary. ${ }^{16}$ He offers a bridge from the "eternal state", which no longer exists, to the state of the "eternal non-return", ${ }^{17}$ to the all-encompassing understanding of temporality and ultimate emptiness as the nature of all things, to the state of homelessness and realising that, "[the] mind is the ultimate paradox because when you start to look for it you can't find it. But when you start to look for something that is not mind you also can't find it." 18 Pelevin's works clearly reflect the author's interest in various belief

\footnotetext{
${ }^{10}$ Dalton-Brown, "The Dialectics of Emptiness," 240.

${ }^{11}$ Aleksei Nomad, “'T.', Viktor Pelevin,” http://www.newslab.ru/review/292551 (accessed June 30, 2011).

${ }^{12}$ Ibid.

${ }^{13}$ More about the urban myths surrounding Pelevin - in section 4.2.

14 Jasper Rees, "Prophet of the Absurd," http://www.independent.co.uk/arts-entertainment/arts-prophet-of-theabsurd-1090104.html (accessed August 11, 2012).

${ }^{15}$ Basinskii, "The Pelevin Syndrome," 96.

${ }^{16}$ Stanislav Gurin, "Pelevin mezhdu budizmom i christianstvom," http://www.pelevin.info/pelevin_152_0.html (accessed July 14, 2011).

${ }^{17}$ As Pelevin writes in the preface to Buddha's Little Finger, "the real value of this document is in the fact that it represents the first attempt in the world culture to embody in the forms of art the Mongolian myth of the Eternal Non-Return." (Victor Pelevin, Buddha's Little Finger, trans. by Andrew Bromfield (New York: Viking, 2000), vii-viii.) Here Pelevin once again presents himself as a creator of the new myths and the new mythical language. ${ }^{18}$ Leo Kropywiansky, interview with Victor Pelevin, http://bombsite.com/issues/79/articles/2481 (accessed December 20, 2010).
} 
systems and metaphysics. ${ }^{19}$ However, it needs to be said that the inter-textual layer of Pelevin's prose does not constitute the primary focus of this thesis, and neither do the multiple allusions to Russian or non-Russian writers, unless it is necessary for the concept of the sacred. The inter-textuality of his prose is itself a broad topic and requires a separate study. $^{20}$

For this thesis, Pelevin's works serve as a testimony of the post-Soviet period. Of course, the gap between the post-Soviet reality and the world depicted in his writings is inevitable. However, he might serve as a guide, an interpreter of that post-Soviet reality, as he accurately feels the pulse of this epoch.

To the best of my knowledge, the type of analysis of Pelevin's prose suggested by this doctoral research has not been done yet. Therefore, his works appear as a promising source for the research on the sacred in the contemporary discourse. Moreover, due to his increasing popularity both in Russia and abroad, this author of highly fashionable fiction could also be said to become an object of cult and devotion, a sacred figure in the post-Soviet milieu. The next section will argue why it could make sense to name Pelevin as a contemporary guru, a sacred figure, with similar importance to Paolo Coelho, Dan Brown and Che Guevara combined. In other words, the next section will discuss Pelevin as having a cultural icon's impact on the mindset of post-Soviet people and hence on their individual notions of the sacred.

\footnotetext{
19 The influence of Buddhism is evident in Pelevin's works. That is how the writer explains his choice: "Buddhism seemed to me to be the only religion that didn't resemble the projection of the Soviet power onto the domain of spirit. It was only much later that I understood that it was exactly the other way around - the Soviet power was an attempt to project the alleged heavenly order onto Earth. Well, Buddhism was totally out of this vicious circle and there was something so strangely compelling and soothing about it." (Ibid.)

${ }^{20}$ That said, the Buddhist context in Pelevin's works is also complex and ambiguous, and requires a separate study. He does not use Buddhist ideas and terms in a systematic fashion. Various allusions in Pelevin's prose point to the author's interest in Mahayana Buddhism (Zen, Tibetan Buddhism, etc); besides, his own understanding and attitude towards Buddhism is changing and evolving with each subsequent book. Therefore this research uses the generic term 'Buddhism' and 'Buddhist' where applicable, specifying (for example, Mahayana Buddhism) only when the context is sufficiently clear.
} 


\subsection{Pelevin as a Sacred Figure}

"Reading Pelevin is like reading a tabloid on LSD while discussing it with a Buddhist
monk. 21

A sacred figure has a legend

Despite Pelevin's avoidance of publicity, he somehow manages to create a mysterious image and is always surrounded by plenty of rumours. ${ }^{22}$ The most well-known examples proclaim him to be: a drug addict and dealer; a gangster; someone who controls a chain of kiosks; and, oddly, a professional disinfector. Finally, some people also say that Pelevin does not exist at all; there is a team of writers working under this name. ${ }^{23}$ Let's not forget yet another version - that Pelevin is a woman.

Alternatively, some people believe that he took the vows of silence and cannot speak to anyone. ${ }^{24}$ In every joke or rumour there is a grain of truth - Pelevin indeed rarely gives interviews, and avoids being in the spotlight or socialising with his fellow writers. ${ }^{25}$ Here is how he explains it:

"I really don't consider myself a part of the literary scene. It's something that is really harmful for a writer to establish and maintain any contact with the so-called literary scene. A literary scene is something that never produces literature. It only produces the so-called literary life, which has nothing to do with books. If you want to write books, you've got to keep as far from it as you can. So I never mix in literary circles. I don't spend my time talking with other writers.",26

\footnotetext{
${ }^{21}$ Author unspecified, http://thisislike.com/victor-pelevin-writer/similar/ (accessed March 8, 2012).

${ }^{22}$ The sunglasses that Pelevin always wears not only add an additional touch to his mystery, but also make him resemble Russian mobsters.

${ }^{23}$ B. Voicechovskij, "Interviu s pisatelem," http://www.pelevin.info/pelevin_139_0.html?page=2 (accessed July 10, 2011). The other source claims to know who writes under Pelevin's name - these are the writers Pokrovskij, Egazarov, Lyapunov, Emelin, Vavilov, Ivannikov, Novickij (note that the first letters of these surnames form Pelevin's surname). (Author unspecified, http://lurkmore.to/\%D0\%9F\%D0\%B5\%D0\%BB\%D0\%B5\%D0\%B2\%D0\%B8\%D0\%BD (accessed March 29, 2012.)

${ }^{24}$ Vasily Prigodich, “Kto takoj Pelevin,” http://www.pelevin.info/pelevin_12_0.html (accessed July 10, 2011).

${ }^{25}$ However, to be fair it has to be admitted that the popular claim that Pelevin does not give interviews at all is an exaggeration. Ironically, the site http://pelevinlive.ru/ contains "46 interviews with the writer, who never gives interviews."

${ }^{26}$ Author unspecified, interview with Viktor Pelevin, "I Never Was a Hero," http://www.guardian.co.uk/books/2000/apr/30/fiction (accessed August 11, 2012 ).
} 
In another interview he also adds: "The reader should be interested in creative works, and not in the personal story of the writer.",27

\section{A sacred figure has followers}

Martin Ganin once made an effort to jokingly describe readers' responses to Pelevin's writings. He divided Pelevin's audience into three groups. Thus, after reading his books, the first group does not quite understand what was so cool and stylish about them, and in general what they were about, so they start criticising the writer. The second group consists of people who 'fully understood' what Pelevin had in mind, and since then have happily chosen him as their guru. The last group accepts the texts more or less adequately, looks at the first two groups not quite understanding what all that fuss about was, and asks, "Are you all crazy?",28

Despite the contradictory opinions surrounding Pelevin's personality and books, a considerable number of fans have actually chosen him to be their guru. ${ }^{29}$ For this significant group Pelevin is the source of their contemporary spirituality: he is a guru and role model for young adults, mostly because of the appeal of being betwixt and between, ${ }^{30}$ the attraction of the scenes with forbidden substances, and the allure of the non-conformist stance. He affirms his non-conformist stance, both with his books and with his life, and appears to be constructing his personal ethics and the sacred. Those holding him as their guru claim: "Pelevin's prose is an unheard-of intellectual drug." 31 As Dmitrij Proskuriakov states, Russian readers await each of Pelevin's new books as a certain discovery, an explanation of an existing situation in society. ${ }^{32}$

Also, it should not be forgotten that Russian reviewers still sardonically assess the general difference between the positions of the writer in the West and in post-Soviet Russia:

\footnotetext{
${ }^{27}$ Danila Toishin, “Interviu so zvezdoyi,” http://pelevin.nov.ru/interview/o-toish/1.html (accessed December 20, 2010).

${ }^{28}$ Martin Ganin, "Viktor Pelevin. T," http://www.openspace.ru/literature/events/details/13262/?expand=yes\#expand (accessed June 30, 2011). Martin Ganin also jokingly admits that this question about the opinion on Pelevin has become similar to that about one's religious denomination, or at least sexual orientation. In other word, it in a sense defines the reader's personality and his general world-view.

${ }^{29}$ When I just started working in the Lithuanian advertising agency in 2003, Generation $P$ was an absolute must-read among advertising copywriters, creative directors, designers and their ilk. Beyond all doubts, at that time Pelevin served as our 'sort of' guru. First, it was because of the writer's understanding of the inside of the advertising business, the irony, deconstruction and final disillusionment with the consumer society. Secondly, he managed to create an illusion that with his next book he will offer a solution to our 'sinful' and 'incorrect' lives, and his next book will present us his version of an absolute escape from this 'absurd and scary' world.

${ }^{30}$ It is clear why being in-between could appeal adolescents - they are in the similar situation, between the childhood and the adult world. More about liminal characters in Pelevin's prose - in section 4.7.

${ }^{31}$ Vasily Prigodich, "Kto takoj Pelevin," http://www.pelevin.info/pelevin_12_0.html (accessed July 10, 2011).

${ }^{32}$ Dmitrij Proskuriakov, "Naidi v sebe chitatelia, ili metafizika i ontologija teksta," http://www.pelevin.info/pelevin_148_0.html?page=1 (accessed June 30, 2011).
} 
"For us the Writer is still a messiah and a prophet, whereas in the West this profession happens to be on the same list as showmen and clowns." 33 This is yet another reason why there is a tendency to deify writers in the post-Soviet milieu, as discussed in the third chapter.

One of the questions asked by a journalist interviewing Pelevin serves as a symptomatic example of the fans' devotion. When Pelevin listed his favourite books, the journalist asked whether he understands how crucial this list will be for those who adore him, adding, "I met your fans who adored the people that knew you, or saw you accidently.",34

Pelevin's fans have created many pages on Facebook, ${ }^{35}$ actively comment on his new books in the various Internet sites, and form new communities united not only with the common interest in his prose, but also with a general interest in the contemporary modes of spirituality, alternative ways of life, and even politics. ${ }^{36}$

One of the virtual places where Pelevin's fans can meet and discuss his works is the discussion board on the popular social network www.vk.com. The titles of the threads are expressive. "What is the meaning of life?" typically asks one of them. Answers come from an eclectic mixture of the self-help books and Eastern philosophy, possibly overheard in Pelevin's texts. ${ }^{37}$ "Is there a life after Pelevin?" asks another; however intriguing the title may be, in this thread people discuss what to read after Pelevin. The deification of this author is evident in the recommendations. For example, one of the discussion participants whose nickname is Evgeny Pustota (borrowed from Buddha's Little Finger!) insists that Chuck Palahniuk would not be good enough - not even Fyodor Dostoevsky. An option might be Vladimir Sorokin or Victor Erofeev, as the latter was recommended even by Pelevin himself. "However, Buddha said not to obey authorities, so ... Buddha's Little Finger forever and ever." ${ }^{, 38}$ Alternatively, another user Leonid Tokarchuk notes that after reading all of Pelevin's works one could start reading him once again. ${ }^{39}$ Lao Tzu, Carlos Castaneda and Dostoevsky can be seen among the other recommendations - a rather accurate context for this author. For a number of fans Pelevin actually serves as the gate to Eastern philosophy, to contemporary

\footnotetext{
${ }^{33}$ Kiril Evlogin, "Prokliatije pisatelia P,” http://www.pelevin.info/pelevin_13_0.html (accessed July 10, 2011).

${ }^{34}$ Author unspecified, "Victor Pelevin: o sekse, mire i sebe," http://pelevinlive.ru/36 (accessed April 4, 2012).

${ }^{35}$ More than 10 pages on Facebook have been created by Pelevins fans as at March, 2012.

${ }^{36}$ For example, Pelevin's fans created an online project Plevman.com, which was positioned as 'the first intellectual social network' and which was meant to be a space to discuss Pelevin's prose and contemporary literature in general. It was supposed to be a closed forum - people could register only by getting invitations from one of the participants. Unfortunately, when I tried to access it on March 29, 2012, the domain name had already expired.

${ }^{37} \mathrm{http://vk.com/topic-784517} 23058194$ (accessed March 29, 2012).

38 Evgeny Pustota, http://vk.com/topic-784517_22732976 (accessed March 29, 2012).

${ }^{39}$ Leonid Tokarchuk, http://vk.com/topic-784517_22732976 (accessed March 29, 2012).
} 
spiritual gurus and New Age handbooks, to the mysteries of magical coincidences and generally to the search for the deeper meaning in everyday reality and beyond. ${ }^{40}$

Popularity has its price, and Pelevin has his enemies. The representatives of the youth group "Idushchije vmeste" ("Going together") actually burned his books. ${ }^{41}$ Apparently all these troubles were in vain, because Pelevin is always "either in Germany, Nepal or in Inner Mongolia, and in general is impossible to catch."

\section{A sacred figure (desirably) has sacred books}

First, Pelevin's novel The Sacred Book of the Werewolf, a werefox's tale of the ultimate liberation, is worth mentioning as an explicit declaration of the 'sacredness'. However, Pelevin's texts in general could be half-jokingly called textbooks for Religious Studies and dictionaries of contemporary mythology. They are also called "the philosophy for the poor", "mythology for dummies", "theology in comics", and "pop-metaphysics". 43

Undoubtedly, Pelevin is an iconic writer: to read his books means to be stylish, contemporary, and up-to-date. It means belonging to an alternative community and taking a non-conformist stance. Generation $P$ and Buddha's Little Finger became cult novels. Paradoxically, as this alternative stance became highly popular, it became mainstream as well. However, for those adoring Pelevin and his creative works, his books have become sacred.

Pelevin successfully combines his religious, political, ideological views and ideas with the paraphernalia of everyday life, pop and counter culture. Reviewers also note that being an expert of bestsellers, he devoted his book Generation $P$ to debunking the creation of such mass-totalitarian myths. ${ }^{44}$ On the same line, a well-known advertising expert Yury Grymov once said that, "Pelevin's literature is the advertisement for literature."

\footnotetext{
${ }^{40}$ Even such trivial events as buying Pelevin's new book can be mystified by the fans. The user Pavel Dren shares his experience on how he has read about his newest book in the newspaper, then told his parents that they have to go to the city to visit a bookstore. That night he had a dream that he is buying Pelevin's book and lacks 30 roubles. He runs back to the car and the car disappears. (Pavel Dren, http://vk.com/topic-784517_21880105 (accessed March 29, 2012). Apparently Pelevin's readers can sometimes find themselves in a sort of Pelevininspired magical reality with mystical coincidences, accidents, and enlightening moments. Beyond doubts, this incident also accurately describes the importance of this author to his fans.

${ }^{41}$ Valia Kotik, "Iz niotkuda v nikuda," http://www.pelevin.info/pelevin_11_0.html (accessed July 10, 2011).

${ }^{42}$ Ibid.

${ }^{43}$ Stanislav Gurin, "Pelevin mezhdu budizmom i christianstvom," http://www.pelevin.info/pelevin_152_0.html (accessed July 14, 2011).

${ }^{44}$ Vladimir Novikov, "Literaturnyj peisazh posle nashestvija Pelevina," http://www.pelevin.info/pelevin_138_0.html?page=3 (accessed July 10, 2011).

${ }^{45}$ B. Voicechovskij, "Interviu s pisatelem," http://www.pelevin.info/pelevin_139_0.html?page=2 (accessed July 10, 2011).
} 
In one of the few accessible online photos (like Carlos Castaneda, Pelevin used to forbid publishing his photos in the media) he is posing in the mountains wearing a T-shirt with the writing "Je ne regrette rien" (translated from French, "I don't regret anything"). This phrase could signify the author's attitude towards society, his own position in that society and his creative legacy. ${ }^{46}$

\section{A sacred figure inspires the followers and ultimately transforms their life}

This statement definitely holds true for Pelevin. Inspired by his books and personality, some readers make the decision to change their lives. ${ }^{47}$ "Pelevin will live forever!" unambiguously states one of his fans Alexander Korovchenko, amongst other declarations of devotion and love, which are abound in the aforementioned site. ${ }^{48}$ Some even confess that they cannot read Pelevin without tears in their eyes. ${ }^{49}$ His fans discuss what a monument to him could be like, and among the many examples: "in the form of a joint", "in the form of emptiness", "in the form of a stylised advertising poster", or "as a can of Pepsi with Kali dancing on top of it". 50

The last reason why Pelevin has gained such great popularity is because he lives his philosophy: people say he is constantly travelling and dividing his time between life in Moscow and Buddhist monasteries in South Korea. ${ }^{51}$ Together with the spiritual masters, such as Chapayev depicted in his books, in one of the interviews he refuses to define himself: "I could not find this 'myself' in many years of meaningless and ruthless meditation practice, and you want me to define myself?"52 In a sense, Pelevin is the embodiment of a new spirituality - one that emerges after religion and after the postmodernist nihilism.

\footnotetext{
${ }^{46}$ This phrase appeared in the famous song by Edith Piaf, and also in the last pages of The Sacred Book of the Werewolf. (Victor Pelevin, The Sacred Book of the Werewolf, trans. by Andrew Bromfield (New York: Penguin Books, 2008), 322.)

${ }^{47}$ For example, the user Provodnik Provodnik shares his story, how after reading The Yellow Arrow he decided to stop being just a passenger. He tried to minimise his dependency on the society, regain his freedom, and begin to work freelance. However, after some time he realised that he cannot maintain his freedom: "After 1.5 years of freedom I became an employee again. Work, family, days off - everything in a circle until I die... Only the dead can be absolutely free." (Provodnik Provodnik, http://vk.com/topic-784517_21880105 (accessed March 29, 2012).

${ }_{48}$ Aleksander Korovchenko, http://vk.com/topic-784517_21880105 (accessed March 29, 2012).

${ }^{49}$ Nikita Kotenko, http://vk.com/topic-784517_21880105 (accessed March 29, 2012).

${ }^{50} \mathrm{http} / / /$ vk.com/topic-784517_24203475 (accessed March 29, 2012).

51 Again, one may doubt whether this is true, and whether Pelevin is merely being a trickster like Castaneda, to prove that he is more than just a pop-Buddhist.

52 Author unspecified, "Interviu s pisatelem Viktorom Pelevinym," http://pelevinlive.ru/46 (accessed March 30, 2012).
} 


\subsection{Liminal Spirituality}

"Me-ism: A search by an individual, in the absence of training in traditional religious tenets, to formulate a personally tailored religion by himself. Most frequently a mishmash of reincarnation, personal dialogue with a nebulously defined god figure, naturalism and karmic eye-for-eye attitudes." 53

The third chapter discussed the change in religious orientation after the break-up of the Soviet Union, when an overwhelming number of people turned to traditional religions, be it the Orthodox Church, Catholicism, or Judaism. However, after this honeymoon period many people stepped back and found the new religious movements, New Age-inspired spirituality (or they simply indulged in the material bliss, which the newly forming consumer culture could offer), or entered into a kind of liminal position, which cannot be described as an indifference to religious, or spiritual questioning, but best summarised by a well-known definition: "spiritual, but not religious."

The fact that traditional religions no longer seem satisfying is not surprising. The return of religiosity, according to the Italian sociologist Roland Benedikter, is an answer to nothingness produced by postmodernity, accompanied by the desire for the "return of essence." However, that desire, as Benedikter argues, is regressive in its nature. ${ }^{55}$ It does not create new forms of thinking and belief. As he also says, it is "a desire for transcendence, a desire for the experience of transcendence, for a personal experience of enlightened consciousness or higher consciousness without a traditional moral structure or a sense of obligation that goes with it." ${ }^{, 56}$ Traditional religiosity could not provide the freedom that a postmodern person craved: not being attached to (and nevertheless feeling the sense of belonging to a group and the sense of being accepted); being a part of the community, but having no obligations to that community; having a sense of certainty but still leaving a window open for new experiences, ideas, and interpretations of such existential questions as the meaning of life, the afterlife, and god. ${ }^{57}$ As Benedikter claims, the nature of postmodern

\footnotetext{
${ }^{53}$ Douglas Coupland, Generation X: Tales for an Accelerated Culture (London: Abacus, 1992), 145.

${ }^{54}$ This phenomenon is well-described in Christopher Partridge, The Re-Enchantment of the West. Volume 1 (London: T\&T Clark, 2004), 46-59.

${ }^{55}$ Roland Benedikter, "Postmodern Spirituality: A Dialogue in Five Parts," http://www.integralworld.net/benedikter1a.html (accessed December 20, 2010).

${ }^{56}$ Ibid.

${ }^{57}$ Benedikter notes that after the break-up of the Soviet Union one could notice not only the renaissance of religions, but also a kind of "growing desire in the post-modern cultures for something that is not religion, but a more direct, more personal broadening of horizons, of consciousness. ... For something, that should be more a
} 
spirituality is that it is all about experience, not about belief. Blind authority and belief with no apparent connection to one's life no longer seem appealing to the postmodern person.

I would argue that Pelevin's prose reflects that search for a new spirituality, which could be entitled a liminal spirituality. It clearly shows the emergence of new forms of the sacred, which are not necessarily connected to any prior religious meanings. Pelevin masterfully creates these new forms, going beyond traditional religious forms and inventing new, more promising belief systems (Omon Ra, Numbers, Empire V, The Sacred Book of the Werewolf, T), which accordingly reflect the great variety of sacred experiences in the postSoviet milieu. Thus, in broader terms, one of the main aims of Pelevin's prose is to frame the elusive concept of the so-called 'new spirituality' or, as Benedikter puts it, to create, "a new essentialism - spirituality for today's needs and abilities", "a self-critical spirituality for the global civil society", or "a rational spirituality that could be an alternative to the beliefs of traditional religions." ${ }^{58}$ However, lying at the core of Pelevin's prose is a niggling doubt as to whether any truly 'sacred' experience is possible in the postmodern or, to put in another way, post-Soviet world (hence Pelevin's irony). This mood reflects the ideas of many contemporary thinkers. The seventh chapter will discuss his position in-between postmodern nothingness and Buddhist notions, further expanding the definitions of the sacred.

\subsection{Deconstruction and the 'Productive Void'}

As mentioned above, the search for what is (and is not) sacred is at the core of Pelevin's prose. ${ }^{59}$ Deconstructing the previous sacred forms, he masterfully creates new ones or, conversely, shows the impossibility of the sacred as an essentialist concept. ${ }^{60}$ This relativity appears as one of the main features of Pelevin's prose, which deconstructs reality, explicitly showing that this reality is constructed, fabricated, and false. In the novel Omon Ra the protagonist Omon reveals that the entire military programme of the Soviet Union and the

personal experience than a religious belief. A psychological or individual growth. For a concrete, meta-rational transformation - but, if possible, firmly grounded on empirical rationality." (Ibid.)

${ }^{58}$ Ibid.

59 Alexander Genis even argues that "despite the popular view that the new wave literature lacks spirituality, Pelevin tends toward spiritualism, proselytism, and hence didacticism." (Alexander Genis, "Borders and Metamorphoses: Viktor Pelevin in the Context of Post-Soviet Literature," in Russian Postmodernism: New Perspectives on Post-Soviet Culture, ed. Mikhail Epstein, Alexander Genis, and Slobodanka Vladiv-Glover (New York: Berghahn Books, 1999), 219.)

${ }^{60}$ This further strengthens the ambiguity of Pelevin's position: even though from the Buddhist perspective it is not possible to talk about the essentialist concepts, he does approach this impossibility as a postmodernist. 
glorious Soviet conquest of outer space are just a myth created by the powerful propaganda machine. Eventually Omon realises that all of his beliefs upon which his life is constructed were based on the lies told by the Soviet authorities. ${ }^{61}$ Hence the author deconstructs the myth of the Soviet power offering possible alternatives. In the novel Buddha's Little Finger the very notion of reality itself is deconstructed, adopting the Buddhist ideas of the empty nature of reality. ${ }^{62}$ Generation $P$ argues that all post-Soviet life is regulated by a giant media machine which forms people's beliefs. Even politicians are not real, depicted as dummies created to engage people's minds. Empire $V$ also denies the common notion of reality, claiming the existence of a secret vampire society and proposing a world creation scheme and meaning. In The Life of Insects the boundaries between humans and insects are blurred; it is not clear which one of these realities is valid. Operation Burning Bush parodies the (de)construction of god. In $T$ the relationship between the author, the protagonist, and the reader is ultimately deconstructed with the deconstruction gesture being especially clearly expressed. Nothing is left after the deconstruction of the author-protagonist relation but the consciousness which produces this deconstruction. This book presents the deconstruction process in all levels: deconstructing the concept of the author, the character, the myth of the creator, and the illusion of the creator and his creations. ${ }^{63}$ As Benedikter argues, if nothing is essential and everything is a construct, then everything can be changed: "it will move us forward - not in spite, but because we have nothing 'essential' or objective left.",64 Deconstructing the previous systems of meaning Pelevin creates new ones. As Alexander Genis notes, "Pelevin does not destroy: he builds. Using the same fragments of the Soviet myth as Sorokin, he constructs both subject matter and concepts."

Pre-modern and modern myths, religion and political ideologies, advertising and Western consumer culture - the new capitalism which emerged in the post-Soviet world - all of these Pelevin shows as constructs. What he offers in his books are sarcastic evaluations of the current epoch, eventually leading to the conclusion that everything can be understood as merely a construct - nothing essential is left. In Omon Ra Pelevin does not suggest any

\footnotetext{
${ }^{61}$ More about Omon $R a-$ in the fifth chapter.

${ }^{62}$ More about the notion of emptiness - in the seventh chapter.

${ }^{63}$ Here is how Benedikter puts the notions of modernity and postmodernity: "The first [modernity] is basically a state of mind where the normal ego and its thinking believe that they are one and the same; the ego identifies with the contents of his thoughts. The second [postmodernity] should be a state of mind where the normal ego and those thoughts, it is identifying with, are additionally being observed by the witness, in the same moment when the ego thinks." (Roland Benedikter, "Postmodern Spirituality: A Dialogue in Five Parts," http://www.integralworld.net/benedikterla.html (accessed December 20, 2010).

${ }^{64}$ Ibid.

${ }^{65}$ Genis, "Borders and Metamorphoses," 214.
} 
solution when the Soviet myth is deconstructed (hence comes the disappointment of his critics, pointing to the 'pessimistic relativism'), but in the other books he attempts to create alternative realities as unified meaning systems (Generation P, Empire V, The Sacred Book of the Werewolf). However, the underlying irony in his texts reveals that this is merely his attempt to show that all the possible explanations of reality can be regarded as constructs, including those so-called credible explanations provided by religious systems or political ideologies. For Pelevin there is no value difference between, say, the Soviet explanation of the world (Omon Ra) and the New Age inspired belief in one's lucky number (Numbers).

In other words, the notion of reality as such is questioned throughout all his books. This question, as Audun J. Mørch rightly notes, can easily become banal, but he also argues that Pelevin does not try to avoid banality. This is how he puts it:

"It would rather seem that he [Pelevin] sometimes tries to master banality; he tries to write in a banal way without becoming boring. ... To describe the same phenomenon differently: when Pelevin asks the major questions such as 'What is real?' and 'Who am I?', he does so with a playful 'tongue-in-cheek' attitude that certainly may be taken for lack of sincerity."

Moreover, Mørch also argues that such a play with banality is one of the reasons why Pelevin is so unpopular among some of his contemporary Russian critics. ${ }^{67}$ As Sofya Khagi notes, "Harshly critical of Soviet mythology in his earlier works, Pelevin reflects here on a depressing value void that opens up following the deconstruction of Socialist utopia. Elsewhere, and now in Russia, commodities serve to disguise metaphysical emptiness." Pelevin shows that everything is a construct; nothing is stable, eternal or untouchable. In Rudolf Otto's or Mircea Eliade's meaning of the word, nothing is sacred. When nothing objective, or essential, is left, it becomes possible to speak of the emergence of the so-called "productive void." 69 Or, to put it another way, there is a possibility of a third way described by Benedikter - between the renaissance of religion and the void left after the postmodernist deconstruction, both spiritual and rational. I argue that, consciously or unconsciously, Pelevin is searching for that 'third way', or is in the process of creating the 'productive void'.

\footnotetext{
${ }^{66}$ Audun J. Mørch, “Reality as Myth: Pelevin’s Čapaev i Pustota,” Scando-Slavica 51, no. 1 (2005): 62.

${ }^{67}$ Ibid.

${ }^{68}$ Sofya Khagi, "From Homo Sovieticus to Homo Zapiens: Viktor Pelevin's Consumer Dystopia," The Russian Review 67, no. 4 (2008): 564.

${ }^{69}$ The creative force that is not an ego that lies behind every mental construct, "that does the deconstruction, but is not itself part of the universal illusion that can be deconstructed. If you try to deconstruct it, you lose everything." (Roland Benedikter, "Postmodern Spirituality: A Dialogue in Five Parts," http://www.integralworld.net/benedikterla.html (accessed December 20, 2010).
} 
Here the notion of the productive void is used not exactly in the sense suggested by Benedikter. The latter claims that "the productive void of postmodernity may be a door to nothingness."70 Instead, I would suggest that (when speaking of Pelevin's works) the productive void can be regarded as a unique mix of the Buddhist concept of emptiness and postmodern nothingness, combined with the liminal state of the post-Soviet person, where nothing essential is left. Out of this all-encompassing void Pelevin creates new formulas for the sacred of contemporary life, trying to explain the world we are living in and at the same time understanding that this explanation is hardly possible if there are no essentialist concepts left. This void opens the door for all possible interpretations and creations of new sacred forms. Hence Pelevin's prose serves as a perfect example of an agreement between Eastern philosophy and postmodernism: the ultimate truth is beyond the mind's grasp. However, as Brant Cortright claims, postmodernism went even further claiming that there is no ultimate truth. $^{71}$

Thus Pelevin's notion of the void, as it will be seen in his books (the most explicitly expressed in Buddha's Little Finger), cannot be reduced either to the (Mahayana) Buddhist notion of emptiness or to a postmodern deconstructing gesture. As mentioned, the seventh chapter will further explore how these two world-views, Eastern and Western, are uniquely combined in a liminal post-Soviet land.

Pelevin's void is a liminal sphere, where the new possibilities for creating the sacred appear and where it is possible to see that everything is merely a construct, even the constructing self. This liminal ground can serve as the possibility to create new forms of the sacred - not essential and not eternal. The sacred is merely a relative and temporary phenomenon: a construct, valid for a certain period of time and not necessarily providing an all-encompassing sense of meaning. This begs the questions, how is it possible to build up new forms of belief while having no essential forms left (when 'nothing is sacred'), nothing that may serve as a solid ground and starting point, and how is it possible to find that solid ground in the state of liminality? Or, to put it another way, how should one live without ever finding solid ground? These are the questions that Pelevin's prose urges the reader to answer.

\footnotetext{
${ }^{70}$ Ibid.

${ }^{71}$ Brant Cortright, Integral Psychology: Yoga, Growth, and Opening the Heart (Albany: State University of New York Press, 2007), 3.
} 


\subsection{Liminality in Pelevin's Texts}

The second chapter noted that the concept of liminality can prove to be useful when speaking of the sacred in post-Soviet literature. Having in mind Victor Turner's identification of sacrality with liminality and secularity with the social structure, it can be argued that the sacred can be actualised in liminal states. As discussed in the first chapter, the sacred is individually constructed and experienced. ${ }^{72}$ Liminality thus can be regarded as an environment to promote a transformative experience, which enables one to form new sacred structures, becoming one of the potential sources of the sacred. This process of liminality also means inhabiting the yet-unknown boundary state of post-Soviet society, naming it and providing it with post-liminal structure.

One could argue whether the term liminality can be valid after more than 20 years of living in the new post-Soviet structure. Post-Soviet society could still be named liminal having in mind the broadened notion of liminality, namely, the notion of permanent liminality elaborated by the sociologist Arpad Szakolczai. ${ }^{73}$ In this case the liminal state would have become permanent, fixed, and frozen. This statement could hold some truth in the post-Soviet context. Indeed some people, after having found themselves in a certain state of social and cultural limbo, being unable to adapt to the changed circumstances, consciously or unconsciously refuse those changes and hence refuse to move forward into the final stage of reintegration. Whereas liminality is a state of hope, of unlimited potentiality, limbo is a state leading nowhere. The symbolism in The Yellow Arrow can serve as a metaphor for this state: people riding the train to nowhere.

However, despite (or perhaps - because of) liminality being such a popular and widely applicable concept, it has become problematic. By detecting liminal zones everywhere, this concept as such loses its precision and meaning. Although liminality was meant to describe the position of individuals experiencing a certain transformation of their role in society, it has become a broader concept, applicable not only in the anthropological scholarship but also in literature, media, social studies, etc. In literary texts liminality paves the way to interpret the characters, who inhabit two worlds and are marginalised, have no

\footnotetext{
${ }^{72}$ Pelevin's works clearly show that the sacred can and should be regarded as purely relative (for example, in the novel Numbers that what is sacred for one person is not necessarily sacred for the other).

${ }^{73}$ For example, Arpad Szakolczai, Reflexive Historical Sociology (London: Routledge, 2000). Alternatively, Bjorn Thomassen goes that far as naming European modernity as being in a constant state of transformation and transgression, a state of 'permanent liminality'. (Bjorn Thomassen, "Anthropology and Its Many Modernities: When Concepts Matter,” Journal of the Royal Anthropological Institute 18 (2012): 160-178.)
} 
clearly set social role. But liminality should not be limited only to literary characters. Thus in Pelevin's prose several types of liminality can be distinguished.

A) Due to various social, economical, political, and cultural changes Pelevin's prose in general can be named liminal, written betwixt and between two epochs, Soviet and postSoviet. This prose serves as a voice of a generation attempting to consciously understand and reflect its own state of liminality between the old order and a new value system that has yet to appear. Standing on the threshold between the old and the newly forming world, it expresses the feeling of temporality, which is an essential feature of the current situation. ${ }^{74}$ In a liminal stage of history, Pelevin's novels also reflect a certain threshold between the past and the future. Liminality, ambiguity, and in-betweenness can not only signify the indecision regarding which direction to take, but can also symbolise the coming of a cultural and spiritual renewal. The old system has collapsed and a new one - strong, leading and convincing - has not yet appeared. Hence The Life of Insects can serve as a metaphor for the post-Soviet generation, neither free nor imprisoned, in a liminal state of mind - the generation which has not been titled yet.

B) Liminality is also represented by liminal characters, living in-between the boundaries, physical and psychological, real and imaginary, or textual. ${ }^{75}$ They can be either clearly liminal beings, inhabiting two worlds and thus acting as mediators, such as vampires in Empire $V,^{76}$ or werewolves in The Sacred Book of the Werewolf (both the human and the beast), or characters between the human's and insect's body, transforming invisibly from one state to another, combining two distinct modes of being into one body (The Life of Insects). ${ }^{77}$ Most plots in Pelevin's books actually begin with the protagonists being in a liminal state, in transition. These can be the borderline personalities stuck at the liminal stage of life with an uncertain social status, such as Pyotr Pustota in the novel Buddha's Little Finger. The latter exists literally between the old and new Russia, between the revolutionary times at the beginning of the $20^{\text {th }}$ century and the end of it, in a kind of schizophrenic state of mind in a

\footnotetext{
${ }^{74}$ For example, Pelevin's novel Buddha's Little Finger can be considered a 'threshold text on various levels', transcending the threshold between the Soviet and post-Soviet literature. (Krystyna A. Steiger, "Satire, Parody, and Nostalgia on the Threshold: Viktor Pelevin's Chapaev i Pustota in the Context of its Times" (PhD diss., McGill University, 2004.)

${ }^{75}$ More about liminal characters - in section 4.7.

${ }^{76}$ About vampires as liminal beings: Lynne Hume, "Liminal Beings and the Undead: Vampires in the $21^{\text {st }}$ Century," in Popular Spiritualities: the Politics of Contemporary Enchantment, ed. Lynne Hume and Kathleen McPhillips (Aldershot: Ashgate Publishing, 2006), 3-17.

${ }^{77}$ Anna Ljuggren also notes the transformatory nature of Pelevin's protagonists (and plots): “The human insects in Iz žizni nasekomych (The Life of Insects) was followed by werewolves in The Sacred Book of the Werewolf and then vampires in Empire $V$. These are dual nature hero-homonyms; the plot connected with them can easily turn out to be a story of metamorphosis." (Anna Ljuggren, "Closing the Circle: On the Poetics of Contemporary Russian Prose," Russian Literature 65, no. 4 (2009): 459-460.)
} 
mental hospital. In Buddha's Little Finger the Soviet/post-Soviet binary is masterfully deconstructed; one protagonist binds together seemingly-impossible-to-merge epochs. Another example is Tatarsky in Generation $P$, who is portrayed being without a clearly defined social role - between his past role as a poet and the current occupation as a copywriter in an advertising agency - adapting Western marketing concepts to the postSoviet reality. Gera from Empire $V$ is the embodiment of the permanent state of liminality. Like Schrödinger's cat, at the end of the novel Gera (similar to the former Ishtar's head) is neither living nor dead, confined to the wall in her limited existence. Being a human being and goddess, and also serving as a mediator between the Goddess Ishtar and the human world, she is stuck in the state of this painful liminality.

The human-insect beings in The Life of Insects appear as a liminal symbol between the Soviet past already gone and post-Soviet present not yet stabilised. These fundamental changes of human mentality could not be addressed in 'human' terms, as the changes were so enormous and all-engulfing. To put it another way, in The Life of Insects Pelevin is observing society in which the change, the liminal state, has become merely a normal mode of life. Thus living in liminal states enables the characters to continue their search for the sacred. ${ }^{78}$

C) Liminality can be traced in rituals as depicted in the literary texts, which include the stage of liminality. ${ }^{79}$ For example, these are initiation rites (the initiation of Rama in Empire $V$, Tatarsky in Generation P, Omon in Omon Ra, and the young boy in the short story Initiation in The Life of Insects). The plot goes from the main character's abandonment of his previous social role to taking another, usually involving the disclosure of the truth about the real structure of society. During the liminal period the state of the protagonist is ambiguous, betwixt and between. In the third phase the protagonist re-enters the social structure, often, but not necessarily, at a higher status level. The liminal, or threshold, periods facilitate transformation and moving to another level of consciousness.

D) The position of the reader can also be called liminal: they are caught in the magically created alternative reality and thus appear on the threshold of where the text ends and reality begins. ${ }^{80}$ Indeed, the act of writing itself can be discussed in terms of liminality (and literary texts are liminal spaces - the reader seeks refuge in this fictional reality and can

\footnotetext{
78 The liminal nature of Pelevin's novels was noticed by some critics, although was not defined in terms of liminality. For example, Alexander Genis defines it as being on the "windowsill, the boundary between different worlds." (Genis, "Borders and Metamorphoses," 217.)

79 The fifth chapter is entirely devoted to rituals, namely, initiation and sacrifice.

${ }^{80}$ The novel $T$ being a perfect example of such masterfully created play with text, authorship and reality.
} 
undergo certain transformations while reading that can change one's real life as well). ${ }^{81}$ Victor Turner has mentioned that writers and artists in general should be able to stand outside of society in order to see beyond it and critically evaluate it. ${ }^{82}$

Pelevin does indeed meet this requirement - he avoids publicity and regards his associations with Russia, Russianness or, for that matter, any other kind of ideology critically. Below is what he says about his perceived Russianness:

"I won't argue that my books are not Russian because they certainly are. But what does it mean for a book to be Russian? Does it mean being soaked in Orthodox Christianity or a belief in the messianic role of Russia, or any seriously taken ideology, the way it often happened in the last two centuries? In this sense I don't think I fit the definition as I was never inspired by anything of the kind. Does it mean following the Russian literary tradition? The only real Russian literary tradition is to write good books in a way nobody did before, so to become a part of the tradition you have to reject it - a condition necessary but not sufficient. ... In my life I have written maximum ten or twenty sentences about Russia, I guess. As every other writer on this planet, I can only write about my mind." 83

However, as it was already noted, Pelevin's prose also demonstrates an attempt to get out of this liminal state by framing the existing reality and trying to come up with the new explanations of the world order and to provide new systems of meaning (as in Empire $V$, Generation P, The Sacred Book of the Werewolf, Buddha's Little Finger, T, and Operation Burning Bush). It also demonstrates the tension between this attempt to create new explanations and at the same time an explicit doubt as to whether these explanations can be attained, since all reality as we perceive it from the five senses is merely a construct of the mind and thus temporary and relative. ${ }^{84}$ Moreover, it can be argued that sarcastically depicting and deconstructing totalitarian Soviet society and the consumer society which replaced it, Pelevin not only creates an alternative explanation for its structure but at the same time creates new systems in his novels, which can to some extent be named 'totalitarian'. That is how the author himself puts this term:

\footnotetext{
${ }^{81}$ The transformative powers of Pelevin's texts were already mentioned in section 4.2.

${ }^{82}$ Victor Turner, Dramas, Fields, and Metaphors; Symbolic Action in Human Society, Symbol, Myth, and Ritual (Ithaca [N.Y.]: Cornell University Press, 1974), 260.

${ }_{83}$ Leo Kropywiansky, interview with Victor Pelevin, http://bombsite.com/issues/79/articles/2481 (accessed December 20, 2010).

${ }^{84}$ That's how Alexander Genis puts it: "For the post-Soviet authors, the world around them represents a sequence of artificial constructs, in which man is forever doomed to search for a 'pure', 'archetypal' reality. Although these parallel worlds are not 'true' in any absolute sense, they are not 'false' either, at least as long as someone believes in them. Each version of the world exists only in each individual soul." (Genis, "Borders and Metamorphoses," 216.)
} 
"The evil magic of any totalitarian regime is based on its presumed capability to embrace and explain all the phenomena, their entire totality, because explanation is control. Hence the term totalitarian." ${ }^{, 85}$

Thus paradoxically denying the possibility of living in a world which can be explained, Pelevin attempts to create his own little totalitarian universes, which itself reflects the painful longing for that era when everything could be and was explained. In this sense his texts can be compared to such works of contemporary pop culture as, for example, the sci-fi film The Matrix (1999), directed by Larry and Andy Wachowski, which also provides us with an alternative explanation of the world and in a sense reflects the longing of the "distant forbidden world". ${ }^{86}$ In such a way contemporary mythology is created, which aims to explain the paradoxes of human existence and to provide the lost sense of the eternity and meaning. As, on another note, Alexander Genis puts it, "inviting post-Soviet Russian literature to cross the ultimate - transcendental - boundary, Pelevin simultaneously tries to show this literature how to cultivate a metaphysical reality, which does not exist, but can be created." ${ }^{, 87}$

E) Finally, liminality is represented with liminal places and times. First, it is the postSoviet era itself - the society in transition - as depicted in literary texts (Numbers, Empire V, and Generation $P$ ). Secondly, these are places that clearly signify the state of liminality, for example, in the novel The Yellow Arrow, the train serves as an existential metaphor for the depiction of the Soviet world as an eternal ride on an unending train. The train signifies the journey - between the beginning and the supposed destination. However, most people are doomed to remain on that perpetual train ride because, as the author puts it, enormous efforts are required to transcend the totalising deceptive reality. ${ }^{88}$

This type of liminal state is described in the following paragraph from Generation P:

“... as these kids lounged on the seashore in the summer, gazing endlessly at a cloudless blue horizon, they drank warm Pepsi-Cola decanted into glass bottles in the city of Novorossiisk and dreamed that some day the distant forbidden world on the far side of the sea will be a part of their own lives." 89

Thus these kids represent the in-betweenness: the dream state, the state of uncertainty, becomingness, in-between the reality and the dream of the forbidden world which one distant

\footnotetext{
${ }^{85}$ Leo Kropywiansky, interview with Victor Pelevin, http://bombsite.com/issues/79/articles/2481 (accessed December 20, 2010).

${ }^{86}$ Or, on the other hand, the film Avatar (2009) by James Cameron which explicitly reflects the longing for the paradise lost.

${ }^{87}$ Genis, "Borders and Metamorphoses," 224.

${ }^{88}$ More about this novel in: Mozur, "Viktor Pelevin," 61.

${ }^{89}$ Pelevin, Homo Zapiens, 1.
} 
day will enter their lives. The dream about the forbidden world can be also deciphered as a dream about the 'New Russia' (literal translation of Novorossiisk), the space and time yet to emerge.

The next section briefly overviews the notion of space and time in Pelevin's prose. It explores the tension between the liminal and the sacred and questions what role liminal places play in his texts. Or, conversely, it asks whether the sacredness of these spaces is tied to liminality.

\subsection{Sacred Space in Pelevin's Prose}

In Pelevin's prose, the general feature of space and time is that indistinguishable inbetweenness, which can be defined in terms of liminality. This nature of being in-between was described as being on the 'window sill': "In Pelevin's stories everything takes place on the 'window sill', the boundary between different worlds. Every boundary underlines as well as creates difference. But a boundary not only divides, it also unites." 90 Therefore, it is crucial to have this liminal nature and in-betweenness in mind when discussing space (and time) in Pelevin's prose. His texts usually take place between the two different epochs, that of the Soviet and post-Soviet. Time in his prose is divided into pre-1991 (the break-up of the Soviet Union) and post-1991. Lenin and Stalin become representatives of the old epoch, whereas Ishtar becomes the representative of the new epoch, of the consumerist society and the monetary sacred. On the same note, Red Square in Moscow can symbolise the old epoch (Omon Ra), and the Ostankino TV Tower (depicted in Pelevin's prose as the new Tower of Babel as in Generation P) symbolises the new one, regardless of the fact that it was built during the Soviet years.

Moreover, space (time) in Pelevin's prose can bring to mind computer games. Here, characters can shift from one level to another, change their identities (The Life of Insects), travel back and forth in time (Buddha's Little Finger), but ultimately they cannot escape this game or this world; they can only move between the different levels of their reality. This is most explicitly depicted in the novel $T$. The search for an authentic mode of being and for the ultimate escape becomes a kind of utopia - something to strive for and never achieve. ${ }^{91}$ The

\footnotetext{
${ }^{90}$ Genis, "Borders and Metamorphoses," 217.

${ }^{91}$ With rare exceptions which are discussed in the last two chapters.
} 
final liberation from the unsatisfactory space-time can thus be regarded as sacred. Metaphorically it was depicted in The Yellow Arrow as leaving the train.

Is there space-time in Pelevin's prose that can be, albeit conditionally, named as sacred? The term 'sacred space' should be used here, keeping the following reasoning in mind. First, the places in Pelevin's prose that will be discussed are not sacred in the traditional sense of this word, that is, they are not necessarily connected to objects and actions that bear any sort of religious significance. Rather, the sacred place will be held as a place, distinguished from other spaces, where rituals are performed (or where objects are kept) directed towards what is sacred. It does not necessarily have to be connected with a transcendent deity. The sacred places can also include space that can be entered not only physically, as the outer geography, but also imaginatively or visually, as mentioned in the second chapter.

Hence, two types of sacred space can be distinguished in Pelevin's prose. The first one belongs to the sphere of objective consensus reality, the other to the sphere of mind. The spaces, which belong to the sphere of mind, can be defined as 'spaces' only relatively and conditionally. Rather, they can be named as states of mind. Examples include Valhalla (Buddha's Little Finger), the Rainbow Stream (The Sacred Book of the Werewolf), Ural, Inner Mongolia (Buddha's Little Finger) and Optina Pustyn (T). These are spaces/states signifying Pelevin's obsession with the eternal non-return. These all (excluding Valhalla) are metaphysical destinations, signifying the ultimate liberation. These will be analysed in the sixth and seventh chapters when discussing the modes of escape.

An example of a 'real' sacred space can be the Tower of Babel (Generation P), yet another reference to Mesopotamian mythology. ${ }^{92}$ It serves as a sacred space in Tatarsky's psychedelic trips and at the same time it has its symbolic representatives in the images of the Ostankino TV Tower and the abandoned tower in the woods near Moscow, where Tatarsky finds himself after the consumption of fly-agarics. ${ }^{93}$

Another space that can be in a sense ascribed to this category is Red Square (Omon $R a$ ), considered to be sacred not only in Omon $R a$. It was one of the most important Soviet sites, holding a sacred meaning. This is unambiguously emphasised in Omon Ra:

"... All cosmonauts, - the mission chief spoke softly, - all of them, no matter how many there were, came before the flight here, to the stones and stands that are sacred

\footnotetext{
${ }^{92}$ It is also a biblical reference. More about the significance of the Tower of Babel - in the sixth chapter.

${ }^{93}$ More about the role of the three towers in the sixth chapter, section 6.2.
} 
to every Soviet person, to take a fragment of this place in their hearts with them to space., ${ }^{94}$

The cosmic space can also be said to be held sacred (idealised in Omon $R a$ ). ${ }^{95}$ These sacred spaces are yet to be reached through liminal spaces. Thus an important notion of space that can also be defined as liminal is the train (The Yellow Arrow), a psychiatric ward (as the metaphor of the world, Buddha's Little Finger), and Lozovaya Junction (as an important place in-between). This section will further discuss the metaphor of the train as holding an important meaning in Pelevin's prose.

Trains are repeating theme in his prose, serving as one of Pelevin's favourite places where his protagonists start (or end) their journeying. ${ }^{96}$ A train signifies a liminal sphere, inbetweenness. This in-betweenness here can be regarded not only as being en route between the beginning of the trip and the destination, but also as that internal liminal state of mind.

The imagery of the train is also highly symbolic and suggestive. Symbolically, the train can be regarded as an image of a birth canal, the continuous journey on the train suggests a passage through this canal, and the unending journey signifies being continuously reborn or, to put it otherwise, being stuck in-between.

To illustrate this argument, there is the final passage of the novel Omon $\mathrm{Ra}$, namely, the episode in the train. After escaping his persecutors in the tunnels, Omon finds himself on the train platform and decides to board the train to an unknown direction or, as the author states, into 'new life': "The patrolling policeman with small dark moustache started shooting me suspicious glances, so when the train came I stepped into the open door without hesitation. The door closed, and I was now riding into my new life." 97 The closure of the door also symbolises the ending of Omon's faith in the Soviet system. This movement can signify stepping into the liminal zone - the ending of the life in the Soviet state and entering another, yet unknown realm. Therefore, the protagonist is ready to be reborn in a new structure.

This episode signifies both the end of Omon's fabricated journey to nowhere and the end of his belief in the values of the Soviet system - and the beginning of a new journey, the destination of which has yet to be decided. However, this time that decision will be made independently and freely. "Still, I had to decide now where I wanted to go. I raised my eyes to the subway map hanging on the opposite wall beside the emergency brake and began to

\footnotetext{
${ }^{94}$ Viktor Pelevin, Omon Ra. Zheltaia strela (Moskva: Vagryus, 2004), 103.

${ }^{95}$ Vast cosmic space acts as a contrast to the unsatisfactory life on the Earth. However, an attempt to escape to the cosmic sphere ironically ends in the tunnels of the Moscow Metro.

${ }^{96}$ For example, in the novels The Yellow Arrow, Omon Ra, T.

${ }^{97}$ Pelevin, Omon Ra. Zheltaia strela, 162.
} 
look where exactly on the red line I was located." 98 Here Pelevin's protagonist faces the common dilemma of the post-Soviet person, who after the break-up of the system found himself in the land of liminality and the multitude of choices facing the necessity to choose for himself and taking the responsibility for his own life. This person has yet to choose his path. Not surprisingly then, that in his following books Pelevin attempts to describe the variety of paths that can be undertaken.

However, the train also emerges as a metaphor of the eternal repetition and meaninglessness in Omon $\mathrm{Ra}$ :

"And this also, I was thinking, all my life I subjugated to the dream of soaring above the throngs of workers and peasants, members of the military and creative intelligentsia, and now, hanging in the glistening black void on the invisible threads of fate, I could see that being a celestial body was something akin to receiving a life sentence in a jail railroad car moving perpetually around the city freight loop., 99

One year after the novel Omon $R a$ the short story The Yellow Arrow was published. This story presents a journey literally on a train named 'The Yellow Arrow' and revolves around the passengers, who appear to no longer comprehend that they are indeed riding on it. They do not know the aim and destination of this journey. The sound of the train's wheels has become such an inseparable part of the passengers' reality that they no longer hear it. They are used to life on the train and do not even think that perhaps something is awry - they have forgotten how they found themselves on it. ${ }^{100}$ The journey seems to be unending; when one of the passengers dies, the body is just thrown through the window of the train. Thus this allegorical story about the train that carries people to nowhere can be interpreted as the basic metaphor of life and, partly, of the life in the Soviet state. Using the metaphor of the train, Pelevin depicts the meaninglessness of life that is not actively reflected upon and questioned.

What is left for the passengers, as one of the characters Han says, is "to ride the train and not to be its passenger." "Therefore, the train signifies the "eternal non-return", and liberation or escape from the train is the only meaningful act, that is, the refusal to accept one's reality as predestined. ${ }^{102}$ In The Yellow Arrow, to understand that one is riding the train is to understand the structure and meaning of the world where one is living. By attempting to

\footnotetext{
98 Ibid.

${ }^{99}$ Ibid., 117.

100 This sort of amnesia reminds of popular New Age beliefs that people forgot their true destinations in life and have to revive them by engaging in various spiritual practices.

${ }^{101}$ Ibid., 181.

${ }^{102}$ In other words, not to repeat the mistake of the young dung beetle in the short story Initiation, who has chosen to repeat his father's life and thus continued his existence in a closed circle of living and death.
} 
explain to the protagonist Andrei that they both are riding on a train heading towards a destroyed bridge, Han acts as a spiritual mentor, trying to open Andrei's eyes into the absurdity of the world and the false beliefs, expressed in the metaphor of the passenger. To be a passenger means not to reflect upon one's life, not to find meaning in it, but to live an unauthentic life.

Eventually Andrei realises he just wants to get out of the train alive. Together with the others he climbs onto the roof of the train, which is described in the story as a sort of a secret mission, a certain ritual. In a sense it can be compared to such activities as meditation, which helps one to get out of consensus reality and observe the world and one's ego. In The Yellow Arrow, it also serves as a metaphor for the road to enlightenment. Pelevin explicitly shows it when mentioning that climbing on the roof of the train is called among those in the know as "the ritual death." ${ }^{, 103}$ Riding on the roof helps Andrei realise that life is more than the train itself. He also realises the possibility to liberate oneself from the confinement of a seemingly never ending and meaningless journey. Thus this story demonstrates the beginning of what eventually will evolve into Pelevin's search for an ultimate escape, as depicted in his later books.

Andrei's successful escape at the end of the story can symbolise the liberation from this world's reality. It is also the beginning of a conscious journey (in this world), the acceptance of the responsibility for one's own life. This story can also be regarded as a metaphorical tale about one's state after the break-up of the Soviet Union and a necessity to undertake a journey of one's own. This story offers hope that, with conscious action, there is a possibility to escape a reality that is no longer satisfactory and to gain freedom, both internal and external. The optimism of this story will be shattered in later books by the increasing doubts whether absolute freedom is possible to achieve at all.

The short story The Yellow Arrow is also important in the context of this research because here the statement can be found about the presumably universal need to have something or someone that can be considered sacred and that can constitute a meaning. "A person, even if he is really good, is always weak, if he is alone. He needs support, something, that would make his existence meaningful. He needs to see the reflection of the highest harmony in everything he is doing."104 The search for the highest harmony and the understanding of one's inability to establish it is further reflected in Pelevin's following books.

\footnotetext{
${ }^{103}$ Pelevin, Omon Ra. Zheltaia strela, 201.

${ }^{104}$ Ibid., 173.
} 
The meaninglessness of the earthly journey on the train is also expressed in Buddha's Little Finger. This is what Pyotr says about the train when he, Anna and Chapayev go to visit weavers in the train, which carries them to the battlefield:

“... [M]an is rather like this train. In exactly the same way he is doomed for all eternity to drag after him out of the past a string of dark and terrible carriages inherited from goodness knows whom. And he calls the meaningless rumbling of this accidental coupling of hopes, opinions and fears his life. And there is no way to avoid this fate." 105

However, Chapayev disagrees with Pyotr saying in a Buddha-like manner, that "there is a way", and immediately illustrates it by detaching the carriage. ${ }^{106}$ This is a perfect, if not literal, illustration of the Buddhist notion of 'detachment'. This is a gesture that will be repeated throughout this story and Pelevin's subsequent novels - an attempt to prove that there is a way to escape from this worldly pain, suffering and attachments. A train to nowhere can still carry a hint of hope.

The importance of the station should also be stressed. In Buddha's Little Finger one of the most important places throughout the text is Lozovaya Junction. It serves both as a place for the decisive battle (at the beginning of the $20^{\text {th }}$ century) and the place where Pyotr's psychiatric ward is located (at the end of the century). This battle also symbolises the conflicts between the two personalities in Pyotr's mind. In this way, Lozovaya Junction can be understood and interpreted as an in-between place, both the battlefield and the mental home, where the essential questions are to be answered and where the road to liberation starts. Lozovaya Junction accentuates and enhances the symbolism of the train. To be in the train is to undergo the seemingly meaningless human journey in the world. To find oneself at the station is to be in a liminal space, one step closer to liberation.

It was already mentioned that liminal characters constitute another type of liminality in Pelevin's works. The next section discusses his protagonists and explores the possible links between their liminal state and the perceived sacredness of their position and/or their need to search for the sacred when being in a liminal position.

\footnotetext{
${ }^{105}$ Pelevin, Buddha's Little Finger, 84.

106 Ibid.
} 


\subsection{Sacred Persons in Pelevin's Prose}

The previous section analysed the space where the plot in Pelevin's books takes place; the focus of this section is on those participating. When creating his characters, he does not limit himself to human beings: his books present humans-insects morphing into one another, vampires, werewolves and werefoxes in contemporary Moscow, and also human beings who apparently have achieved a sort of enlightenment state. The choice of non-human, liminal characters such as insects, vampires and werewolves explicitly show Pelevin's need to express those enormous changes that took place during the post-Soviet years. This is also his way of showing human nature as unstable and elusive. Constant change becomes a driving power in Pelevin's works, and an unending inspiration for his subsequent books. It is a reflection of a state of post-Soviet people, who try to find their identity and destination in the changed world. These people are lost in their own images and roles as their belief system is no longer secure, stable and reliable. They eventually find themselves in transition and in the 'eternal becoming'.

Often these characters in transition, in the state of in-between, receive help from those who have already achieved a high level of spiritual mastery or have just reached the top ladder of society. Sacred persons can include prophets, sages, saints, spiritual masters; in other words, these are the ones who have experienced unitary consciousness and who can lead others on the spiritual path. This section uses the term 'sacred persons' as a general category to name characters in Pelevin's prose who either achieved a high level of spiritual mastery in their practised belief systems, or who themselves became god-like figures. The role of the teachers (mentors) and that of the god-like figures will be discussed, and how these aforementioned persons can reflect what is sacred in Pelevin's prose will be analysed.

The main characters in his books can be generally paired into the teachers and disciples, the latter being in the liminal state. For example, in The Yellow Arrow such a duo consists of the protagonist Andrei and his mentor Han. In Generation $P$ the protagonist Tatarsky can be said to have two mentors. The first one is Gireev, and the second (conditionally) could be Azadovsky (and to a certain extent, Morkovin, who introduces him to the world of advertising). In Buddha's Little Finger Pyotr has Chapayev as his spiritual mentor, and he also briefly meets Baron Jungern. In The Sacred Book of the Werewolf A HuLi meets the Yellow Master, who introduces her to the notion of liberation. In Empire $V$ Rama has two teachers, Baldr and Yegova, who introduce him to the vampire society, but 
Mitra and Osiris can be regarded as his mentors in the broader sense of this word. In Numbers Stepa has his New Age expert Prostislav (although it is more of a parody of a spiritual master), and in $T$ the protagonist Count T. has Ariel for endless metaphysical discussions. In Operation Burning Bush Dobrosvet can be conditionally named Semyon's teacher (conditionally, because mainly psychedelics help Semyon to achieve a god-like state of mind).

These teachers, or spiritual mentors, generally support the protagonists through their liminal stage and introduce them to the new world they are about to enter. In some cases, they appear only briefly (like the Yellow Master, Baron Jungern, or Osiris). In the other cases, the teacher and the disciple go hand-in-hand throughout the story (Chapayev, Prostislav and Dobrosvet). Then the protagonists either achieve the aim that their teacher thought the most important (Pyotr, A Hu-Li, Andrei), or they choose their own path and abandon the teaching of their master (Tatarsky and Gireev, Rama and Osiris. Both Osiris and Gireev fail to convince the protagonists of their truthfulness). In the novel $T$ Ariel is eventually demystified and Count T. abandons his creator to search for his personal meaning and truth. In some cases, the person that could be conditionally called teacher has to be sacrificed so that the protagonist could achieve the top ladder of the society (Mitra, Azadovsky). ${ }^{107}$

There are also figures in Pelevin's books that could be called sacred or god-like, for example, Ishtar (Generation P, or the Mighty Bat as in Empire V). She can be said to have her antipode (Lenin/Stalin). Thus Ishtar can be regarded as representing the post-Soviet world and the monetary power/sacred, whereas Lenin (Stalin) represents the Soviet past. At the end of the novel Empire $V$ one of the protagonists, Gera, becomes an embodiment of the goddess figure. In The Sacred Book of the Werewolf the super-werewolf is briefly mentioned (the figure resembling Jesus Christ), but this notion is not evolved further. Eventually A Hu- $\mathrm{Li}$ achieves liberation and becomes a sacred person herself. In the novel Numbers the number 34 (and, alternatively, 43) can be regarded as a sort of sacred figure, according to which the whole life of the protagonist is being organised.

Chapayev (Buddha's Little Finger) can also be regarded as a semi-sacred figure, inbetween that of a spiritual master and a Buddha-like person. It is worth discussing the example of Chapayev as one of the most expressive pictures of the spiritual mentor. The cases of Baron Jungern and Gireev (Buddha's Little Finger) also need to be mentioned to see how these operate in the same novel and what significance they have. Also, the figure of

${ }^{107}$ Sacrifice is further discussed in the fifth chapter. 
Ishtar should be discussed, mentioning her importance as the representative of the monetary sacred in the post-Soviet consumer society.

The deconstruction of the 'traditional' sacred persons can be explicitly seen in the portrayal of Maria in Buddha's Little Finger. ${ }^{108}$ In a sense, Chapayev's portrayal can also be seen as the deconstruction of the traditional sacred, as Chapayev in Russian history was also elevated to the position of a sacred person, but in an absolutely different sense. Pelevin takes the famous cultural icons and deconstructs their image and perception (the same technique he uses in the novel $T$, in the depiction of the Count T. and Dostoyevsky).

\section{Vasily Chapayev}

One of the most colourful figures in Pelevin's prose is Chapayev, who appears in Buddha's Little Finger. ${ }^{109}$ The prototype of this character is Vasily Ivanovich Chapayev (1887-1919), who was a famous Red Army commander during the Russian Civil War. After the book Chapayev by Dmitri Furmanov (1923) and subsequent movie (1934) he gained a sanctified mythic image, becoming a legend and a hero, and later a popular character in Russian folklore immortalised in countless Russian jokes.

In Pelevin's novel, this historical Chapayev now appears as a guru, a spiritual master whose aim is to explain to Pyotr the notion of emptiness and the real nature of the universe. This odd trinity, consisting of Chapayev, Pyotr and a machine-gunner, Anna, finally reach their state of “eternal non-return”, or Inner Mongolia, using Chapayev's clay machine gun. ${ }^{110}$ Chapayev connects the Soviet and post-Soviet universe, explicitly showing the elusive and illusory nature of time and space, and the ultimate emptiness of all objects and concepts.

It takes a while for Pyotr to understand who Chapayev is. He approaches Pyotr after the latter murders his friend von Erner and takes up his name to avoid persecution. This is how Pyotr feels immediately after meeting Chapayev:

\footnotetext{
${ }^{108}$ Maria is one of the patients in Pyotr's psychiatric ward. This protagonist identifies himself with Maria - a character from the Mexican soap opera Simply Maria, popular in the early post-Soviet years. This might also be Pelevin's allusion to the Virgin Mary.

${ }^{109}$ Although he is mentioned in the novel $T$ as well - this is Pelevin's favourite inter-textual play.

${ }^{110}$ As Chapayev puts it, "It isn't really a machine-gun at all. It's simply that many millennia ago, long before the Buddha Dipankara and the Buddha Shakyamuni came into the world, there lived the Buddha Anagama. He didn't waste any time on explanations, he simply pointed at things with the little finger of his left hand, and their true nature was instantly revealed. When he pointed to a mountain, it disappeared, when he pointed to a river, that disappeared too. It's a long story, but in short it all ended with him pointing to himself with his little finger and then disappearing. All that was left of him was that little finger from his left hand, which his disciples hid in a lump of clay. The clay machine-gun is that lump of clay with the Buddha's finger concealed within it." (Pelevin, Buddha's Little Finger, 305.)
} 
"I did not know what he wanted from me, but I decided for the time being to play according to his rules; furthermore, I felt instinctively that I could trust him. For some reason I had the impression that this man stood several flights above me on the eternal staircase of being which I had seen in my dream that morning."

Chapayev takes Pyotr to his division, and thus a teacher-disciple relationship starts to evolve. Eventually he succeeds in proving that Pyotr cannot define himself, and for that matter, nothing is definable. This is how he states it: "Everything that we see is located in our consciousness, Petka. Which means we can't say that our consciousness is located anywhere. We're nowhere for the simple reason that there is no place in which we can be said to be located. That's why we're nowhere.",112

This leads to Pyotr's further questioning:

"If the entire world exists within me, then where do I exist? And if I exist within this world, then where, in what place in the world, is my consciousness located? One might say, I thought, that on the one hand the world exists in me and on the other I exist in the world, and these are simply the poles of a single semantic magnet, but the tricky thing was that there was no peg on which to hang this magnet, this dialectic dyad. There was nowhere for it to exist!"

Thus Chapayev initiates his young disciple into the notion of emptiness or void. He also discusses the concept of liberation:

"'If they wake you up from your nightmares the same way they did that Chinaman, Petka,' Chapaev said without opening his eyes, 'all that'll happen is that you'll drop from one dream into another. You've been flitting to and fro like that all eternity. But if you can understand that absolutely everything that happens to you is a dream, then it won't matter a damn what kind of dreams you have. And when you wake up afterwards, you'll really wake up - forever. If you want to, that is.",114

This is a direct allusion to the notion of liberation as in Buddhism. With the depiction of this character Pelevin explicitly demonstrates his liking for Buddhist philosophy, where the relationship of the teacher and the disciple holds an important role. The final escape, or liberation, can be achieved with the help of a person who has already undergone this path. The word 'escape' is not accidental. The subsequent chapters will analyse the notions of escape and liberation in Pelevin's prose, which will help further explore the sacred.

\footnotetext{
111 Ibid., 70 .

112 Ibid., 144.

113 Ibid., 149.

${ }^{114}$ Ibid., 207.
} 


\section{Baron Jungern}

Another spiritual teacher and master, who appears only briefly in the pages of Buddha's Little Finger, but who nevertheless is an important figure, is Baron Jungern, the ruler of the mythic Valhalla, which resembles the space from Scandinavian mythology where those that die in the battle descend. As Chapayev puts it, Baron Jungern is "the defender of Inner Mongolia. They say he is an incarnation of the god of war. He used to command the Asian Cavalry Division, but now he commands the Special Regiment of Tibetan Cossacks." 115 He is a defender of Valhalla, which in Pelevin's book serves as one of the branches of the world beyond the grave. Valhalla is supposed to be the afterworld of the warriors but, as Pelevin ironically puts it, also the place where those high on psychedelics can find themselves. ${ }^{116}$ This character helps Pyotr to further understand the ultimate emptiness of this world. However, perhaps even more important, he points out to the astonishing parallels between the Buddhist thought and the Soviet ideology. This is Baron Jungern's version of Buddha's story of enlightenment (as it could be interpreted):

"There was once a man who could not live as others did. He tried to understand what everything meant - all the things that happened to him from day to day; and who he himself was - the person to whom all those things were happening. And then, one night in October when he was sitting under the crown of a tree, he raised his eyes to the sky and saw a bright star. At that moment he understood everything with such absolute clarity that to this day the echo of that distant second ..."117

This parallel can be even more strengthened: "This is the eternal flame of the compassion of Buddha. And what you call a pentagram is really the emblem of the Order of the October Star." 118 The October star, the Soviet symbol, here serves for Buddha as an ultimate trigger for his enlightenment. This can be understood as Pelevin's ironic attempt to prove that all ideologies or religious beliefs whatsoever still carry on the same character. They are by no means different in their core essence. They are confining and not liberating, and the ultimate escape would be an escape from all ideologies and belief systems. According to this interpretation, even the Soviet power could not be considered as ultimately evil (or Buddhism as ultimately good). Emptiness is in the nature of all ideologies. Baron Jungern's

\footnotetext{
${ }^{115}$ Ibid., 210.

${ }^{116}$ As Baron Jungern says, "it's not only warriors who find their way here, but all kinds of other trash who have gone in for shooting. Bandits, murderers - the range of scum we get is amazing, which is why I have to make the rounds and check on things." (Ibid., 214.)

${ }^{117}$ Ibid., 217.

${ }^{118}$ Ibid., 216.
} 
Valhalla serves as a neutral zone, the zone of enlightenment, where both Pyotr's worlds, that of the beginning of the $20^{\text {th }}$ century and the end of it, can be finally regarded as inherently illusory. ${ }^{119}$

In Buddha's Little Finger the metaphor for permanently leaving this world and the cycle of eternal rebirth is being discharged from the mental hospital. That is how Baron Jungern puts it:

"Both of your obsessive states - with Chapaev and without him - are equally illusory. In order to reach 'nowhere' and ascend that throne of eternal freedom and happiness, it is enough to remove the single dimension which still remains - the one, that is, in which you see me and yourself. Which is what my own wards are attempting to do. But their chances are very slim, and after a certain period of time they are obliged to repeat the weary round of existence. Why should you, however, not find yourself in this 'nowhere' while you are still alive? I swear to you that this is the very best thing you could possibly do with your life. No doubt you are fond of metaphors - you could compare this to discharging yourself from the mental home."

This world is compared to a mental hospital, and freeing oneself from this place no doubt has a clear association with the Buddhist notion of liberation. Here Baron Jungern can also be regarded as a sort of Bodhisattva, who reached his Inner Mongolia (or enlightenment in Buddhist terms), but then came back to help his fellows on this path:

“"And so...' I asked, 'you have been there?'

'Yes,' replied the Baron.

'Then why did you return?'

The baron nodded without speaking in the direction of the camp-fire, where the silent Cossacks were huddled."121

\section{Andrei Gireev}

Andrei Gireev is Tatarsky's classmate from the Literary Institute (another classmate is Morkovin, who serves as a mentor in the world of the monetary sacred). In Generation $P$ he is portrayed as Tatarsky's teacher, albeit with a hint of irony. It is Gireev who first introduces Tatarsky to hallucinogenic mushrooms. As Tatarsky puts it, Gireev allows him "to live a parallel life." ${ }^{122}$ Gireev can be seen as an unfulfilled spiritual master, typical for the post-

\footnotetext{
${ }^{119}$ Ibid., 220.

${ }^{120}$ Ibid., 223.

${ }^{121}$ Ibid., 235.

${ }^{122}$ Pelevin, Homo Zapiens, 226.
} 
Soviet consumerist culture. Eventually, seduced by the monetary sacred, Tatarsky starts seeing Gireev as a loser:

"It often happens: you're talking to someone, and you kind of like what he's saying, and there seems to be some truth in it. Then suddenly you notice he's wearing an old tee shirt, his slippers are darned, his trousers are patched at the knee and the furniture in his room is worn and cheap. You look a bit closer and all around you you see signs of humiliating poverty you didn't notice before, and you realize everything your interlocutor has done and thought in his life has failed to lead him to that single victory that you wanted so badly on that distant May morning when you gritted your teeth and promised yourself you wouldn't lose, even though it still wasn't really very clear just who you were playing with and what the game was. And although it hasn't become the slightest bit clearer since then, you immediately lose interest in what he's saying." 123

Thus Tatarsky refuses to see Gireev as his spiritual mentor, and instead he turns to the world of the monetary sacred and monetary power represented by the image of the Goddess Ishtar.

\section{Ishtar, the Monetary Goddess of the New Millennium}

One of the most discernible god-like figures in Pelevin's prose is Ishtar, the Babylonian and Assyrian goddess of fertility, love and sexuality. In Generation $P$ she represents the totality of advertising images, the deified advertising business as a whole. In other words, she becomes the goddess representing the monetary sacred, the goddess of consumerism. She is gold; as Azadovsky states, "not just the metal, though: in a metaphorical sense." ${ }^{\prime 24}$ Ishtar presents herself as a monetary god of the post-Soviet era. She is an image, a symbol and, at the same time, an embodiment of the consumer society, a hidden goddess of contemporary Russia, the new Babylon. Tatarsky becomes the new ritual husband of the goddess and enters into a mystical union with her as a 3D image in advertising material. This is an allusion to post-Soviet life in general, to that greed with which people seek material goods after suffering from constant shortage during the Soviet years.

The image of Ishtar in Generation P clearly depicts the shift from the transcendent, other-worldly god figures into the 'postmodernised' ones which represent the materialistic consumer society itself.

\footnotetext{
${ }^{123}$ Ibid., 223-224.

${ }^{124}$ Ibid., 238.
} 
The same can be said about Ishtar (the Mighty Bat) in Empire V. Here the Goddess Ishtar created vampires to help her remember the meaning of life and explain why she has created this world. This sort of amnesia reflects the cultural amnesia of the post-Soviet years in general, and the deconstruction of the previous sacred figures in particular. At the end of the novel Empire $V$ one of the protagonists, Gera, actually becomes an embodiment of the goddess figure. Pelevin portrays this with the expressive image of Gera's head attached to the body of the Mighty Bat. This shows the blurred boundaries between the god-like figures and humans in Pelevin's prose and in postmodern world in general. However, this also can signify the state of imprisonment for post-Soviet people, despite their seemingly free state, as portrayed by Pelevin. They are now strongly attached to the materialistic, consumerist culture.

\subsection{Conclusions}

"People who use the phrase, 'In these changing times, when the only thing that's certain is change itself' are idiots," states Douglas Coupland in a rather presumptuous manner. ${ }^{125}$ Unfortunately, this phrase proves to be useful when discussing the post-Soviet context and Pelevin's prose. The role of liminality might seem ambiguous and overemphasised, but its importance for the discourse of the sacred in post-Soviet society is undeniable. This concept helps to frame, name and explain the ongoing processes in the postSoviet milieu. This milieu can be described as: the in-between zone of silence, of unstable and mixed values; or the zone without a false sense of security, where one does not have anything stable. Hence one faces the need to find the identity and meaning, the sacred.

This chapter emphasised Pelevin as a writer and the cultural icon's impact on postSoviet people, broadening their horizons as to what can be constituted as the sacred. For many of them his fiction served as an introduction to Buddhism, to the critical and analytical questioning of the world around, and for many this was the first glance into the void. Beyond doubts, his writings influenced their understanding of what the sacred is, what it could be, and that it is not necessarily limited only to the traditional religious frameworks. Pelevin does not only write about post-Soviet reality - his books ultimately form and influence that reality by spreading new, provocative ideas. Thus, paradoxically, to a certain extent his books

${ }^{125}$ Douglas Coupland, JPod (New York: Bloomsbury, 2006), 7. 
become a powerful tool to shape a new ideology and a source for creating the new sacred. Also, Pelevin as a cultural icon and a sacred figure gives an impulse to create new communities, united by this quest for the new sacred.

This chapter determined that Pelevin's prose can be a favourable ground to explore the concept of the sacred and its spread in the post-Soviet milieu, as liminality is a constant theme in his texts which are born out of the feeling of/and being in liminality. The liminal position of the protagonist can facilitate their involvement in the search for the sacred. Liminality actualises the need to search for the sacred; it inspires and empowers. The liminal spirituality (or, in Benedikter's terms, the productive void), that is a dominant feature of the post-Soviet condition further strengthens that need.

The analysis of the sacred spaces in Pelevin's prose further emphasises the importance of the notion of liminality. Although most of the protagonists in his books have their mentors or spiritual teachers to guide them, they still seem to a large extent to be wandering as if stuck in the dark rooms and corridors of this world without knowing where they are going and their ultimate destination. The dark rooms and corridors here in this text serve merely as a metaphor. However, the corridors, underground, closed spaces and trains are indeed common places in Pelevin's texts and thus emphasise once more the uncertainty and liminality of the protagonists' positions. For example, Omon spends his days and nights training in the tiny cabin of the spaceship in the underground and escapes through the tunnels of the metro. Pyotr is locked in a psychiatric clinic; in his parallel life he also boards the train with Chapayev and Anna (the symbolism of the train was already discussed in this chapter and is evident not only in Buddha's Little Finger and The Yellow Arrow but also in the novel T). Darkness and closed spaces are common characteristics of 'this world' and serve as an opposition for the search for freedom that will be discussed in the seventh chapter.

Finding themselves in a liminal state, Pelevin's protagonists encounter sacred persons - those spiritual masters or god-like figures. This would prove the argument that in the liminal state the search for the sacred can be actualised. This sacred is not necessarily connected to religious meanings - eventually Tatarsky (Generation P) and Stepa (Numbers) aim for the monetary sacred. On this road to their perceived enlightenment or higher understanding the protagonists undergo a certain initiatory process. Therefore, the next chapter will continue with the analysis of initiation (and sacrifice as part of the initiatory process) in Pelevin's books, and discuss whether it can serve us as a tool to disclose the new structures of the sacred that can be seen unfolding in the post-Soviet milieu. 


\title{
Chapter 5:
}

\section{Initiation and Sacrifice in V. Pelevin's Prose}

\begin{abstract}
"The only things that differentiate us from animals are the rules and rituals which we have agreed on among ourselves. To transgress them is worse than to die, because only they separate us from the abyss of chaos which lies at our very feet - if, of course, we remove the blindfold from our eyes."1
\end{abstract}

These words by the Japanese businessman Kawabata in the novel Buddha's Little Finger eloquently summarise the importance of rituals in society. Even though this sophisticated discussion between Kawabata and Serdyuk takes place during the ritual of an excessive drinking - so common in Russian culture - nevertheless these words do not cease to be significant.

The theoretical assumptions relating to rituals were already discussed in the second chapter. It was noted that for this research, ritual is important as a certain mode of acting directed towards what is considered to be sacred. Ritual serves as a means by which people establish and maintain their relation to the sacred. Any activity can be ritualised as long as it provides that connection.

This chapter continues with the analysis of initiation and sacrifice as depicted in Pelevin's books. As initiation and sacrifice are closely intertwined in his works, these notions are discussed simultaneously. Initiation rituals often include sacrifice, and sacrificing in general can signify one's entering into another position in the societal hierarchy. However, the focus here is on initiation; thus my primary interest in sacrifice is how it is associated with initiation and its ultimate cost.

In this section, five examples of initiation processes are chosen as case studies: the episode in Omon $R a$ with Omon at the Air Force Academy; a young boy's journey into adulthood in the short story conveniently titled Initiation (The Life of Insects); Tatarsky's initiation into a secret society which controls the mass media (Generation P); Rama's initiation into the vampire society (Empire V); and the ultimate transformation of the protagonist in the novella Operation Burning Bush (Pineapple Water for the Fair Lady). In

\footnotetext{
${ }^{1}$ Pelevin, Buddha's Little Finger, 165.
} 
all these episodes the protagonists abandon their previous (social) role to take on another, becoming aware of society's true structure (and, in some way, the meaning of existence).

Consequently, this chapter discusses several examples of sacrifice. First, it is Omon's sacrifice at the altar of the Soviet power (as in Omon Ra; this sacrifice in a broader sense can also be compared to the (Soviet) Bodhisattva ideal, resembling A Hu-Li in The Sacred Book of the Werewolf). Secondly, it is A Hu-Li's case and her sacrificing liberation for her loved one. Thirdly, it is the sacrificing of Azadovsky in order to place Tatarsky in the position as the ritual husband of the Goddess Ishtar (Generation P). It is also Tatarsky's sacrifice of his ideals, establishing his conformist stance. Fourthly, resembling Azadovsky's case is Mitra's sacrifice in order to put Rama into the highest rank of the vampire society (Empire V). This also signifies Rama's sacrifice of his naïve faith. This chapter also briefly mentions Ishtar's sacrifice, when the goddess is killed to replace her with the new one (Empire V). Finally, a few words should be said about the significance of the death of the father (Initiation, from The Life of Insects), which could resemble a sacrificial act, and the role of the death of Dobrosvet (Operation Burning Bush).

\subsection{The Making of a Soviet Man}

Before proceeding with sacrifice as depicted in Pelevin's works, it is important to note the specificity of the context, namely, the notion of suffering in Russian history and culture in general. A brilliant study on this topic was written by Daniel Rancour-Laferriere. In his book, eloquently named The Slave Soul of Russia: Moral Masochism and the Cult of Suffering, he notes that "Russian history offers numerous examples of the exploitation and debasement of human beings." "2 Drawing examples from the Mongol invasion to the post-Soviet period, the author emphasises the sheer quantity and diversity of suffering in Russia. He argues that there is a thirst for self-destruction and self-sacrifice that is deeply embedded in the Russian psyche. I would further note that in some sense it is the longing for sacrifice, for something that would prove one's life to be meaningful, and would help to connect with what is considered to be sacred. This thirst for sacrifice and this willingness to sacrifice can be seen as a longing for the sacred in Russian mentality. It is the mentality of victimisation, a need for

\footnotetext{
${ }^{2}$ Daniel Rancour-Laferriere, The Slave Soul of Russia: Moral Masochism and the Cult of Suffering (New York: New York University Press, 1995), 4.
} 
suffering and self-destruction. Rancour-Laferriere goes even further describing Russians as not only merely suffering but as having invented the cult of suffering. One of his examples is the traditional metaphor used when talking about Russians during the tsarist times: 'a slave of god.' It is an expression of dependency and submission, of addiction to sacrifice. Holiness and sacrifice are thus quite inseparable and the link between suffering and sanctity is evident. ${ }^{3}$

Only through suffering can the sacred be achieved - freedom paradoxically becomes sinful as only slavishness is sacred. It could even be argued that the so-called Russian soul is a curious mixture of the striving for freedom and an attraction to slavery. This context might prove to be helpful when discussing the notion of sacrifice in Pelevin's works.

It is in his first novel Omon $R a$ that the concept of sacrifice emerges. In fact, it is a book not only about the debunking of the myth of Soviet power, but also about the role of human sacrifice. This is how Pelevin himself describes the writing of Omon Ra:

"Writing Omon Ra, I sometimes felt scared of what I was doing. But this fear was residual, like white noise - there was no real danger. The political aspect of this book wasn't really important to me. I didn't write a satire of the Soviet space program, as the book was branded both in Russia and abroad. It was a novel about coming of age in a world that is absurd and scary. My part of the scary world was Russia, so I wrote a book where the space quest - a metaphor of the entire Soviet myth - became a background. The book was dedicated to the heroes of the Soviet Cosmos, not just 'space'.,"

Here Pelevin presents his novel as a story of the coming of age in the Soviet world. It can be seen as a story of an initiation process, and the political scene, although important, remains here in the background. Cosmic space, as already noted by Pelevin, is only a metaphor for the Soviet empire.

The book is written from the first person, Omon Krivomazov's, point of view. Omon's father had chosen his name after OMON - Soviet special police forces. The other association with the Egyptian Sun god Amon Ra will later be strengthened by Omon choosing the nickname $\mathrm{Ra}$ in the secret cosmonaut academy. ${ }^{5}$ Omon's father wanted him to be a policeman, but from early childhood he had a wish to become a cosmonaut. As the

\footnotetext{
${ }^{3}$ For that matter, the problem of alcoholism, which is so significant in Russia, also shows the masochistic character, as alcoholism is masochistic in its nature.

${ }^{4}$ Leo Kropywiansky, interview with Victor Pelevin, http://bombsite.com/issues/79/articles/2481 (accessed December 20, 2010).

${ }^{5}$ The worship of the human-sun matches the aims of the totalitarian system: the sun here can be regarded as a metaphor of the highest unquestionable power and sacred (think Louis XIV le Grand, Le Roi Soleil).
} 
protagonist puts it, "from my childhood I only managed to remember that which was related, so to say, to my dreams of the sky." ${ }^{, 6}$ Not accidently Omon mentions that their apartment was not far from the movie theatre 'Cosmos', and that he as a personality started from "a wooden airplane installed on the playground on our block."7 The symbolism of the cosmos continues throughout the entire novel. Understanding that "no peace or freedom can exist here on Earth," $" 8$ and that he will never be free in the Soviet state unless he breaks free of Earth's gravity, he and his best friend Mityok enroll in the Air Force Academy after finishing school. ${ }^{9}$ Ironically enough, the Academy is situated in the town Zaraisk - in Russian this word carries on a meaning 'beyond paradise'. ${ }^{10}$

During the examination process Omon is asked what he would do if his Motherland asks him to sacrifice his life for it. He answers in the affirmative without doubts, not realising that this was the essential question. Both Mityok and Omon are accepted to the Academy. As the lieutenant later states, the mission of the Academy is "not to simply make you into pilots, but to make you into real men, right? And when you receive your diplomas and military ranks, you can be sure that by that time you are going to become Real Men, with the capital M, as capital as it only can be in the Soviet country." "11 Thus, the Academy serves not only for the imparting of the skills of piloting but also as a place for the transformation into 'real Soviet' persons. The ideal image of such a man, as the lieutenant later relates, is depicted in Boris Polevoy's socialist realist novel The Story of a Real Man. ${ }^{12}$ This is about the famous Soviet hero, Alexei Maresiev, who allegedly after losing his legs in battle did not surrender or quit but continued to fight. This is how the lieutenant conveys this story:

"He, who after losing both of his legs in battle, did not surrender but instead soared as Icarus into the sky to continue pounding the Nazi beast! Many have told him it was impossible, but he always remembered that he was a Soviet man!"13

Unfortunately, it soon becomes evident that those accepted to the Academy are doomed for the same fate as Alexei Maresiev. Their legs are amputated, thus strengthening the connection with the previous Soviet hero and making them 'real men', sacrificing them

\footnotetext{
${ }^{6}$ Pelevin, Omon Ra. Zheltaia strela, 9.

${ }^{7}$ Ibid., 9-10.

${ }^{8}$ Ibid., 13.

${ }^{9}$ Omon's friend Mityok shares the same passion: he "was unsure about many things, but there was one thing he knew for certain. He knew that he would become a pilot first, and then he would fly to the Moon." (Ibid.)

${ }^{10}$ Interestingly enough, such a town actually exists.

${ }^{11}$ Ibid., 35.

${ }^{12}$ Povest o nastoiashchem cheloveke (1949).

${ }^{13}$ Pelevin, Omon Ra. Zheltaia strela, 35-36.
} 
for the Soviet military power. As Roman Ivashkiv puts it, "The amputations point to a fanatical submission to Soviet leadership, as well as unflinching readiness to sacrifice human beings for the sake of an idea." ${ }^{14}$ This also serves as an initiatory process - the cadets are first separated from their usual environment in the Academy, put in the liminal place of 'beyond paradise', then the change of their physical appearance takes place, ${ }^{15}$ and then they (supposedly) enter into their new stage of life.

However, Omon and Mityok escape this execution. They are told instead that they will be heading to Moscow to the secret cosmonaut school, to prepare for a suicide mission to the moon. Hence they are placed in the underground KGB headquarters and spend their time training with absurd devices. Omon finds himself in a small community of other men, all with the same suicidal mission, in a manually operated spacecraft.

Eventually Omon is doomed to sacrifice his own life for the sake of the legendary Soviet cosmic power - the state here becoming a substitute for the transcendent sacred. Omon's being in a tiny cabin of a 'spaceship' contrasts with the vast cosmic spaces, the same contrast being that of the Communist ideology proclaiming the bright future for the Soviet people versus their actual life in tiny communal rooms and the poverty of their everyday life. He is thus captured - there is nowhere to escape. Captivated by the glorious images of the Soviet cosmic power, and by his overwhelming desire to escape into the cosmic space, Omon is chosen as a perfect sacrifice on that very same altar of the Soviet power. This sacrifice is meant to keep that power intact, to restore and renew it. The illusory power of the Soviet state is paradoxically nourished with illusions, falsely created from the very start.

As mentioned in the second chapter, according to René Girard, sacrifice is an act of violence performed on a surrogate victim - the so-called 'surrogate victim mechanism'. "Because the victim is sacred, it is criminal to kill him - but the victim is sacred only because he is to be killed." ${ }^{\prime 6}$ Otherwise that blame, instead of being concentrated on a particular object, can spread to everybody and threaten the very structure of society. Omon's strive to escape into the cosmic space, his unwillingness to stay in the Soviet reality, and to face the absurdity of life in the Soviet state makes him a perfect victim and places him outside society. It turns him into a marginal, or liminal, individual. This status, as Girard argues, prevents this future victim from establishing or sharing the social bonds, and thus leads him

\footnotetext{
${ }^{14}$ Roman Ivashkiv, "Postmodern Approaches to Representation of Reality in Ukrainian and Russian Literatures: The Prose of Yuri Andrukhovych and Viktor Pelevin," Journal of Ukrainian Studies 32, no. 1 (2007): 52.

15 "In the place where Slava's feet were supposed to be, his blanket stepped sharply down instead, and the freshly starched sheet there was bearing fuzzy reddish blots, the kind you see watermelon juice leave on white kitchen towels." (Pelevin, Omon Ra. Zheltaia strela, 37-38.)

${ }^{16}$ Girard, Violence and the Sacred, 1.
} 
to his vulnerability and victimization. ${ }^{17}$ "The sacrifice serves to protect the entire community from its own violence; it prompts the entire community to choose victims outside itself." 18 In order to maintain the illusory harmony in Soviet society, constant sacrificing is required. But, contrary to the traditional understanding of sacrifice, even this sacrificial mechanism is presented as false and fabricated. A surrogate victim is found in order to maintain that elusive stability of an otherwise unstable society, or as the Soviet Union presented, the perfect society subject to destruction at any moment.

Due to the specificity of the Soviet psyche, violence also cannot be expressed outwards so instead it is turned inwards, directed towards the self, towards self-sacrifice and self-victimization. People consciously accept the role of the victim. Also, Omon's sacrifice in a curious way resembles the notion of the Bodhisattva in the Mahayana Buddhist tradition. In a sense, Omon also acts as the Bodhisattva, accepting the need to sacrifice his own life for the sake of the others, in this case for the sake of his country. In the Soviet state, people were ideologically brainwashed to be ready to sacrifice their life for an ideological construct, which had little to do with reality. The life of one individual was of little value, if any. By sacrificing his life for the sake of his country, which appears to be a non-existent entity, Omon acts, albeit unwillingly, as the Bodhisattva. Hence there is a resemblance between A Hu-Li's (The Sacred Book of the Werewolf) and Omon's sacrifices. The protagonist, A Hu$\mathrm{Li}$, acts as the Bodhisattva when she postpones her liberation for the sake of her loved one.

After completing his task, Omon was required to commit suicide, but instead he decides to venture out into space and here he finally discovers that the whole myth of the Soviet cosmic power was a farce - their spacecraft was actually flying nowhere. Instead, they were still confined underground in the Moscow Metro. The heroic achievements in space exploration proved to be nothing but the lies of Soviet propaganda.

In the broader sense, this novel is about Omon's initiation into a 'real' world. After the liminal time in the underground, separated from the rest of the world and training for his final mission (transformation), he comes out finally realising all the absurdity of the Soviet establishment and Soviet cosmic power.

Pelevin's argument is clear: a belief in reality that actually does not exist can replace reality and become a satisfactory simulacrum. His idea that nothing exists in reality proves to

\footnotetext{
${ }^{17}$ Victims are characterised by Girard as "beings who are either outside or on the fringes of society: prisoners of war, slaves, pharmakos. ... What we are dealing with, therefore, are exterior or marginal individuals, incapable of establishing or sharing the social bonds that link the rest of the inhabitants. Their status as foreigners or enemies, their servile condition, or simply their age prevents these future victims from fully integrating themselves into the community." (Ibid., 12.)

${ }^{18}$ Ibid., 8.
} 
be especially applicable in this context. Even if the moon's conquest exists only in the mind of one person, it can nevertheless become embodied. Omon's sacrifice is meaningless and useless, but it can hold a special meaning to the community, while bonding and strengthening the faith in the objects and concepts that are actually empty and meaningless. As Urchagin, one of Omon's teachers, states:

"Even one pure and honest soul is enough for our country to become the leader in space exploration. One such soul is enough for the red banner of victorious socialism to unfurl high above the Moon. But at least one soul, for at least one moment - is indispensable, because it is in this soul that the banner will be soaring ..."19

Therefore, the tension between the truth and the lie, the real and the imagined, proves to be irrelevant, as it is the belief of a person which embodies the desired truth and reality.

The ending of the novel Omon $\mathrm{Ra}$ might seem to break the illusions of the sacred. It symbolically marks the ending of the belief in Soviet power, which is no longer valid in the post-Soviet milieu. Pelevin demonstrates the absurdity of the system - and of the belief in a system - which is falsely constructed from the very beginning. Here, what was sacred for the Soviet people is clearly shown as relative, temporary and unstable. The protagonist has to continue and organise his life without the previous sacred dimension. This also marks a new beginning and a new and conscious choice as to what the sacred could be. This ending is also a metaphor for the liminal state of post-Soviet people as depicted by Pelevin - left without the previous belief system and no new system ready to take its place.

The totalitarian state is represented in Omon $R a$ through the simulation of the powerful force of space exploration, and the Communist ideology serves as a form of the sacred. However, instead of the conquering the cosmos myth Pelevin offers a story of the ultimate deception. The racket here becomes a symbol of the transcendence which is permanently lost, as this transcendence is now simulated in the undergrounds of the Moscow Metro. ${ }^{20}$ The cosmonauts who once were the sacred icons of the Soviet mythology, half-men and half-gods, here are powerless: the victims of fabricated sacrifice. Instead of becoming a sacred person, Omon becomes an outcast.

The symbolism of Omon's escape was already discussed in the fourth chapter. In short, it is the ultimate victory for him - he eventually sacrifices the collective ideology for the sake of his personal 'enlightenment'.

\footnotetext{
${ }^{19}$ Pelevin, Omon Ra. Zheltaia strela, 158.

${ }^{20}$ The same motif is repeated in Generation $P$, where initiation takes place underground, below the Ostankino TV Tower.
} 
To sum up, in the novel Omon $R a$, Pelevin's protagonist faces the common dilemma of the post-Soviet person, who after the system's break-up found himself in the liminal zone and had to take the responsibility for his own life. In his later books, Omon's quest for freedom, expressed by his desire to escape into the cosmic space, is continued by other narrations of the human need for freedom. The ultimate expression of such a quest is a final liberation (as in The Sacred Book of the Werewolf or Buddha's Little Finger).

\subsection{Becoming an Adult}

The short story Initiation from the book The Life of Insects presents yet another example of the initiatory process. Throughout all the episodes in this book the characters experience a metamorphosis from human to insect form. They are in a constant state of transition between the forms of the human and the insect, acting like humans and appearing like insects and vice versa. The metamorphosis is shown as an absolutely normal process, and the boundaries between the human and insect forms are blurred if not erased. Each world is depicted as 'real', that is, there is no reason to doubt either their human or insect form.

Each story, as Keith Livers notes, presents a character or characters undergoing physical or spiritual transformations during which they question the meaning of life. ${ }^{21}$ Thus in Initiation, a young boy (or a young dung beetle) with the gentle guidance from his father gradually comes to the realisation that life is just a series of waking and sleeping, all the time pushing the dung ball. This process of realisation carries on the traditional features of initiation. For example, as in the traditional coming of age ritual, the young person is guided by the elder who already knows the mysteries of existence.

The initiation ritual is not necessarily connected with reaching the age of puberty. ${ }^{22}$ That is how Jean Sybil La Fontaine explains the broader meanings of the initiation process:

"The rituals may also regulate access to assets more tangible than knowledge: the support of a large organization, control of property, the establishment of a household, fees for specialist services. These rewards for initiation must be derived from the social setting of the rites, rather than the details of what is done or said, which are

\footnotetext{
${ }^{21}$ Keith Livers, "Bugs in the Body Politic: The Search for Self in Viktor Pelevin's The Life of Insects," Slavic and East European Journal 46, no. 1 (2002): 3.

${ }^{22}$ Jean Sybil La Fontaine, Initiation (Manchester: Manchester University Press, 1986), 14.
} 
overly concerned with what may be termed 'ultimate values': birth, death, mystical powers and human development." 23

This example of initiation can also be interpreted in various ways: a coming of age story; an initiation into a certain community. The story starts with the boy and his father (still supposedly in their human appearance) on the road. The road and the journey themselves signify being in a liminal state: between the point of departure and the destination. The journey is also a transformatory process, during which certain knowledge is to be gained. It is a place where the questions of meaning emerge: "Strange thoughts unlike any he'd had before began filling his mind, thoughts he would never have had in an ordinary place." ${ }^{24}$ The road that father and son take is covered in fog: "The only thing they could see was the concrete beneath their feet." ${ }^{, 25}$ The symbolism of the road is even more emphasised by the image of fog symbolising the unknown. The first question with which the boy starts his 'existential' journey is what the fog is made of. "Where are we going," the boy keeps asking, trying to frame and explain their liminal state. Afraid of this uncertainty, of getting lost, he no longer can see the light. ${ }^{26}$ It is that darkness and the fear of the unknown that signifies the liminal sphere.

The father continues to give his son pieces of dung, which the son carefully puts in his plastic bag without questioning. Finally all the dung spills out and the father explains to the young boy that he has become a grown man now. "Think of today as your second birthday. ... From now on, you won't be able to carry all your dung. From now on, you'll have your own Ai, just like me and your mother." 27 The notion of "Ai' here can be understood as realising one's ego, individuality, and himself as a separate person. It is also a repetitive motif of the coming of age when a kid separates himself from his parents in order to become an independent person. According to the father's explanation, Ai is "a sacred Egyptian syllable that dung beetles have used for thousands of years as the name for their spheres." ${ }^{28}$ Instead of the dung ball, the boy sees a "large, semitransparent blue-brown sphere", ${ }^{29}$ and the father explains that he was too young to see that 'sacred sphere' before. Everything in life appears to be dung, that is, Ai, and the purpose of one's life is to push it along in front of oneself.

\footnotetext{
${ }^{23}$ Ibid., 17.

${ }^{24}$ Victor Pelevin, The Life of Insects, translated by Andrew Bromfield (New York: Farrar, Straus and Giroux, 1998), 20.

${ }^{25}$ Ibid., 19.

${ }^{26}$ Ibid., 20.

${ }^{27}$ Ibid., 21.

${ }^{28}$ Ibid., 22. 'Ai' can be interpreted as 'I'. In Russian version Pelevin uses 'Йa', that is, ' $Я$ ', meaning the first person singular personal pronoun.

${ }^{29}$ Ibid., 21 .
} 
However, the father cannot provide the answer to the boy's question of how one can see the ball from the inside and at the same time push it along. Here, Pelevin ironically imitates paradoxical metaphysical questions showing the impossibility to answer them. ${ }^{30}$

The father claims that the way to knowledge is only through experience, not through the theoretical explanations. His son has to find out the secret of existence experientially. ${ }^{31}$ The transformation of the boy from human to insect can be seen only after he finally understands the meaning of life and Ai. Just a few paragraphs before, the boy was depicted in human terms as he "shrugged sceptically." Shortly afterwards he covers "his face with his front legs." 32 However, that is not the end of the boy's rite of passage. Finally, he understands that life is not only pushing the dung ball, but rolling inside the dung ball.

"And is all of life like this, smashing your face against the concrete ...

'But life is fine and beautiful, anyway,' said his father in a slightly threatening tone." 33

The young boy does not dare to argue or rebel. The meaning of life, that what is sacred, is to be accepted as a tradition introduced to him by his father. Pelevin parodies advice from self-help literature with the father saying "after all, we're responsible for our own mood and everything else, too", 34 showing that the father is far from being satisfied with his life. This sounds like a compromise or, to put it another way, an excuse. The boy is not supposed to question their state or the meaning provided. Here a presupposition can also be made that the whole world as a dung ball might also serve as a metaphor for the Soviet society.

The anthropological literature discusses the importance of the act of sacrifice in initiation rituals. In initiation into maturity, it is common to experience suffering and physical change. ${ }^{35}$ Also, in order to become a member of a certain community, the initiate has to perform sacrifice. This can include, for example, killing an animal. The death of the father in the final paragraphs of this short story serves as a sacrifice or a symbolic change of generations where the old generation departs and the new one takes its place. Here, the boy

\footnotetext{
${ }^{30}$ Pelevin also makes a reference to his favourite Egyptian mythology, when the father says that all insects have their Ais, but "the dung beetles who know about it are called scarabs. The scarabs are the ones who possess the ancient knowledge of the essential meaning of life." (Ibid., 25-26.)

${ }^{31}$ Note the resemblance to the arguments of religionists such as Rudolf Otto, who argued that the sacred can only be experienced, not explained.

${ }^{32}$ Ibid., 25.

${ }^{33}$ Ibid., 27.

${ }^{34}$ Ibid., 28.

${ }^{35}$ La Fontaine, Initiation, 16.
} 
discovers new knowledge, which is also the most important knowledge for his life, but at the same time he loses the most significant person in his life. Ironically, the boy finds comfort in traditional religious belief: "Pa's soul has flown up to heaven." 36 Once again Pelevin emphasises that this character is left at the same state as his father was, namely, in traditional thinking and beliefs. He does not dare go further in questioning the meaning of life but instead relies on the meaning provided to him by the elder. Hence he is doomed to repeat his father's life and to complete his journey, which seemingly has no meaning. This journey can symbolise the condition of the (post) Soviet people in general; those whose search for purpose and meaning is being controlled and limited, who rely on the meaning proposed by their forbears. The last words of the boy, who has now finally completed his transformation (the death of his father also signifies the change of generations and the boy's state as a grown-up), is nothing but a compromise, refusing to go further with the existential questions that had arisen in that liminal state:

"Ai'll grow up and get married, Ai'll have children, and Ai'll teach them everything my pa taught me. And Ai'll be as kind to them as my pa was with me, and when Ai get old, they'll take care of me, and we'll all live a long and happy life."37

Thus the boy refuses the journey of questioning and instead of that limits himself to the safe zone, repeating what his parents and grandparents did. This perfectly reflects the state of the Soviet people and their fear of change. The image of the ball serves as a symbol of eternity, a 'myth of the eternal return' - the eternal repetition as opposed to the transformation and change. As Keith Liver puts it:

"By the time he [the boy] attains adulthood at the end of the episode, he has already succeeded in merging his life with the mythologized ball of dung known to his kind as 'Ai [la]'. Rather than continue on the path of self-interrogation, he gradually joins the eternal circle of Myth whose meaning had been passed down to him by his father." 38

Initiation also defines boundaries "between members of a group and outsiders, between different statuses and between contrasted ideas." ${ }^{39}$ In this short story the boundaries

\footnotetext{
${ }^{36}$ Pelevin, The Life of Insects, 30.

${ }^{37}$ Ibid.

${ }^{38}$ Livers, "Bugs in the Body Politic," 7.

${ }^{39}$ La Fontaine, Initiation, 16.
} 
are clearly defined. The father and the son belong to the group whose members are united by their belief system.

Pelevin's choice to depict the metamorphosis of humans into insects is not only an allusion to Franz Kafka's novel. It is possible that the changes, which had taken place in the post-Soviet era, were so enormous and all-engulfing for most people that they simply could not be addressed in 'human' terms. These had to be the fundamental changes of the human mentality, and that could not be described in terms of traditional rites of passage, hence the role of insects. ${ }^{40}$ Insects thus appear as a liminal symbol between the Soviet past already gone and the not yet stabilised post-Soviet present. The short life span of the insects only further emphasises temporality and liminality.

The Life of Insects can serve as a metaphor for depicting the post-Soviet generation in a liminal state, which has a choice of either staying in the 'safe zone' where the former beliefs of the sacred remain, or taking a risk and going out of this zone to search for new alternatives.

\subsection{Becoming a God}

The third initiation episode is presented in one of the most well-known of Pelevin's books, Generation $P$. The main protagonist of the book is Vavilen Tatarsky, whose name serves as an acronym for Vasily Aksenov, Vladimir Ilyich Lenin. ${ }^{41}$ Tatarsky is a former student of the Literary Institute and a poet, who gave up his poetry writing after the break-up of the Soviet Union to become an advertising copywriter. Gradually he finds out that what he worked for are actually fabricated events and people, and that he writes texts for merely $3 \mathrm{D}$ digitised dummies on TV. There is also a powerful secret society behind it which controls their creation and actions as well as decides what should be said and done. Eventually

\footnotetext{
${ }^{40}$ That is how Alexander Genis addresses this dualism: "One could say that post-Soviet authors are seeking symmetry in the world of beasts: while in the Soviet era, sots-realism portrayed men as half-god and half-man, in the post-Soviet era they are portrayed as half-man and half-beast." (Genis, "Borders and Metamorphoses," 219.)

${ }^{41}$ In the English translation, the name Vavilen is changed with Babylen. While Pelevin's intended explanation of the origin of this name was that "it was composed from the names of 'Vasily Aksenov' and 'Vladimir Ilich Lenin'," the translator Andrew Bromfield changed this sentence into "he composed it from the title of Yevtushenko's famous poem 'Ba-by Yar' and Lenin'. This change can be justified by the translator's need to emphasise Pelevin's play with the words Вавилон (Vavilon) and Вавилен (Vavilen), as Tatarsky further in the text identifies his name with the name of the city, Babylon, which is written with a typing error. More about this and other problems with the translations of Pelevin's texts in http://www.russianwriters.eu/en/pelevin/pelevintranslations.html (accessed 30 June, 2011).
} 
Tatarsky is invited into one of the meetings of that secret society and undergoes an initiation process in order to become one of them. Moreover, during the ceremony he becomes the new boss of this organisation.

The ritual takes place 100 metres below the Ostankino TV Tower, which also serves as a kind of sacred space (not to forget that the main interest of that secret society is to control the media). Thus Tatarsky is transformed from the former poet and erstwhile kiosk salesman into a copywriter in the advertising industry, and finally, after an initiation process, into a media god: the ritual husband of the Goddess Ishtar. He gains the power to control the mass media and, accordingly, the consciousness of people. Becoming a god-like figure, he is immortalised in the form of a TV image.

Here initiation serves as a means for entering the secret society, which controls the world governed by 3D digitised dummies on TV. However, Pelevin emphasises that people who organise this ceremony actually do not believe in the meaning of it and understand it as merely a tradition. Tatarsky's guide in the initiation process, Azadovsky, clearly shows that this ritual process carries no special significance for him, only that it is a tradition: "Personally I couldn't give a toss for all this, but if you want to be in our business, you can't get by without it." ${ }^{, 2}$ The initiation process here is just a decoration, although with all the necessary attributes.

During this process a totally naked and blindfold Tatarsky is led into the Golden Room. Stripping and being left alone is a common feature in initiation rituals into secret societies. ${ }^{43}$ He enters through a long and dark corridor (darkness, appearing in a kind of a liminal zone, is essential in this ritual and this image is also highly suggestive of the womb). Then he gets dressed in a supposedly ancient skirt, takes a golden mask and a mirror, and enters into the Golden Room, which is literally made of gold, with a golden altar and symbols from Babylon mythology. Here he is expected to look at the sacred eye. As it is explained to him, it is the required tradition and also the moment when the goddess chooses her husband.

The motifs of the Mesopotamian mythology continue throughout most of Pelevin's books, as will be seen in the following chapters. ${ }^{44}$ In Generation $P$ the Goddess Ishtar represents the totality of advertising images and the deified advertising business as a whole. Speaking of the myth of Ishtar, Azadovsky tells that they "took away the goddess' body and reduced her to a pure concept. She became gold - not just the metal, though: in a

\footnotetext{
${ }^{42}$ Pelevin, Homo Zapiens, 237.

${ }^{43}$ La Fontaine, Initiation, 49.

${ }^{44}$ For example, in Empire $V$ this goddess is also linked to the consumer impulses.
} 
metaphorical sense." ${ }^{45}$ Ishtar presents herself as the monetary goddess of the post-Soviet era: she is an image, a symbol, and at the same time, the embodiment of the consumer society, the hidden goddess of contemporary Russia, the new Babylon. The main sacral function of the ritual husband of Ishtar is to enter into a mystical union with the goddess as a 3D image in advertising material. Thus during the ceremony, Azadovsky, the previous ritual husband of Ishtar, is strangled, and Tatarsky becomes the next one, entering into a 'sacred union' with the goddess, who in general represents the materialistic approach to life. This is an allusion to post-Soviet life in general, to that greed with which people seek material goods after suffering from the constant shortage in the Soviet years. The ritual behaviour in Generation $P$ shows the shift from the appeal for transcendent god figures to the 'postmodernised' ancient god figure which represents nothing but the materialistic consumer society itself. To conclude, Pelevin's post-Soviet people pray to material, consumer gods and their behaviour is regulated through the mass media and advertising images.

This initiation scene presents the typical features that signify entering into the liminal space. At first the protagonist is not aware of the true structure of the world; he is naïve, ignorant and innocent. Then he gradually rejects his old identity (nakedness, unknown space, fear). Finally he experiences the union with the higher being or force and completes the transformation process. As in Initiation, where the boy symbolically takes the place of his father after his death, here Tatarsky too takes Azadovsky's place as the ritual husband of the goddess.

When asked during his job interview whether there is anything at all that he believes in, Tatarsky answers: "No." ${ }^{, 46}$ However, this initiation scene illustrates that at the end he has decided on his faith and chosen his belief system: the monetary power represented by Ishtar. Actually Tatarsky becomes a god-like figure, as now he is in charge of creating the reality for the Russian people. Pyotr in Buddha's Little Finger searched for personal salvation, whereas Tatarsky took the position of the person who creates images of 'salvation' for other people. He gains the power to decide what people will believe and what they will crave for - such is the power of advertising, successfully replacing religious power in consumer society. Thus, after the demise of the Soviet eternity, monetarism becomes Tatarsky's new form of belief. Money is the main drive of society and a means of constructing the systems of meaning in the world. Lyudmila Parts argues that:

\footnotetext{
${ }^{45}$ Pelevin, Homo Zapiens, 238.

${ }^{46}$ Ibid., 153.
} 
"Since the relation to culture is the main part of the intelligentsia's self-image, letting it go leaves Vavilen with nothing. Having lost this secular version of faith in immortality, he faces the nightmarish reality of Dostoevsky's faithless heroes."

Post-Soviet Russia in Generation $P$ is portrayed as the society of consumerism. However, this belief is also a simulation. Repeating the 'traditional' ritual process, no-one in the secret society seems to really believe in the meaning of that ritual. As Sally Dalton-Brown puts it, "Pelevin suggests simulacrum engendered by false ideology, void created from void in a seemingly eternal process of recapitulation of past decadent civilisations." ${ }^{48}$ As satire and irony is employed in this novel, this does not allow the trusting of Pelevin's seemingly pessimistic conclusions about contemporary society. This makes Generation $P$ not only a novel focusing on monetarism and the influence of TV, but also an ironic account of the change of the sacred in contemporary society. Sofya Khagi names Generation $P$ as "the first major post-Soviet work to come to grips with the introduction of consumer capitalism and global pop culture." 49

However, Pelevin does not make value judgments about whether the post-Soviet period is better/worse than the Soviet era. Moreover, binaries of 'good' or 'bad' are erased, and the only important things that are left are the mental processes, the continuous reevaluation and rebuilding of identities. Sofya Khagi also argues that the book "portrays a total collapse of spirituality" and that "the desacralization of culture described by Pelevin has overwhelming spiritual implications for the people's spirit at large." emphasises the 'traditional' understanding of the sacred and employs a certain value criteria, which are not valid in the context of this research with an expanded understanding of the sacred.

Pelevin also does not avoid using the terms 'sacred space' or 'sacral function' depicting the initiatory process in the text, thus strengthening the link with the traditional notions of ritual's intent to establish contact with what is held to be sacred. Moreover, the preoccupation with the 'eternal' questions, such as immortality, the meaning of life, and the

\footnotetext{
${ }^{47}$ Parts, "Degradation of the Word," 444.

${ }^{48}$ Dalton-Brown, "The Dialectics of Emptiness," 243.

${ }^{49}$ Sofya Khagi, "From Homo Sovieticus to Homo Zapiens: Viktor Pelevin's Consumer Dystopia," The Russian Review 67, no. 4 (2008): 559. She also compares Generation P with such important novels as Aldous Huxley's Brave New World and George Orwell's 1984, arguing that Generation P "falls in line with numerous European and American postmodern dystopias that, following Huxley, focus on the ennoblement of greed and covert varieties of control in contemporary society. Pynchon's Vineland, DeLillo's White Noise, Coupland's Generation X: Tales for an Accelerated Culture, and Palahniuk's Fight Club are some examples of such work." (Ibid., 562.)

${ }^{50}$ Ibid., 566.
} 
employment of traditional explanations, mythologies, beliefs, and 'postmodernised' rituals explicitly show Pelevin's need to question and redefine what is sacred in contemporary society.

\subsection{The Great Fall from Grace}

Despite Pelevin's astonishing productivity, critics claim that his works seem to be built upon a core narrative matrix. ${ }^{51}$ This Pelevin's one-book plot could be defined as a story of transformation from a 'normal' human being into a god-like figure or an 'enlightened' being. ${ }^{52}$ However, such transformation from human to god is not necessarily an elevation. In some cases, as in Generation P, Empire V, or Operation Burning Bush, it can be regarded as self-destruction. ${ }^{53}$

Empire $V$ in many ways seems to be re-articulating the main motifs of Pelevin's works. It also can be regarded as a coming of age story, an initiation. This time he has chosen a highly popular community in contemporary culture, that of vampires, and depicts the life of vampires, combining the realities of post-Soviet life with his own fantasies, both well-known and newly invented myths, blending the rational and magical.

Although the stories, tales, legends and myths about vampires, or vampire-like creatures, demons and spirits, have existed for millennia, only in the $18^{\text {th }}$ century did they start to gain the image that is predominant now. Bram Stoker's Dracula (1897) has become a sort of vampire Bible and never-ending inspiration for contemporary vampire fiction. There is no shortage of plots about vampires in popular literature. It is enough to remember The Vampire Chronicles by Anne Rice (1976-2003), The Twilight series by Stephanie Meyer (2005-2008), Vampire Academy by Richelle Mead (2007-present). The movies and TV series are also abundant: Blade (and, subsequently, Blade II and Blade: Trinity) by Stephen Norrington (1998), Buffy the Vampire Slayer (TV series, 1997-2003), Interview with Vampire: the Vampire Chronicles by Neil Jordan (1994), Bram Stoker's Dracula by Francis

\footnotetext{
${ }^{51}$ As some literary critics put it, for many years Pelevin keeps on writing the same book. For example, in Dmitrij Proskuriakov, "Naidi v sebe chitatelia, ili metafizika i ontologija teksta," http://www.pelevin.info/pelevin_148_0.html?page=1 (accessed June 30, 2011). Proskuriakov emphasises that this 'book' can be named as a metaphysical novel on spiritual searching and discovering the ultimate truths. ${ }^{52}$ Pyotr in Buddha's Little Finger, A Hu-Li in The Sacred Book of the Werewolf, Tatarsky in Generation P, Rama in Empire V, Semyon in Operation Burning Bush.

${ }^{53}$ However, in terms of this research, it can be incorrect to apply such value criteria, that is, claim that the monetary sacred should be considered as 'worse'.
} 
Ford Coppola (1992), True Blood (TV series, 2008-present), to name but a few. These books, movies, and TV series remain very popular throughout the world.

One of the explanations for this astonishing popularity is the irresistible attraction and magnetism of the vampire fantasy - the charm of the supernatural, the possibility of the immortality, the romantic, sensual and sexual aura surrounding these creatures of the night and darkness. It is also a dangerously attractive transgression of the boundaries between the worlds of the living and the dead - the liminal state - the paradoxical power of an outcast's position. After all, vampires are also attractive because of the supposed possibility of victory against death, which might be interpreted as the ultimate human fantasy.

Vampires in popular imagination are those taking on a human appearance but who nevertheless also have qualities that liken them to gods. They generally consume the life essence (that is, blood) of living creatures. However, choosing to use these popular characters Pelevin transforms their image, adding new qualities and characteristics to their portrait and making 'the post-Soviet vampire society'. For instance, instead of hanging out as ghost-like creatures with their mouths covered in blood, Pelevin's vampires live in contemporary Moscow among the rest of the people, have their own hierarchy and, of course, a fancy dress code. Instead of drinking blood they choose more modern means to suck the life essence from people. Some might argue that in this way they have lost part of their charm as opposed to those depicted in modern fiction.

The story in Empire $V$ revolves around a young guy Roma. Kidnapped by the vampire Brama, he is unwillingly turned into a vampire and replaces Brama, who thus commits a sophisticated suicide (the truth being, death is a complicated affair in the vampire world). The vampire tongue, the essence and soul of the vampire, is transplanted from Brama's into Roma's body.

The vampire tongue here also can operate as a metaphor for the necessity to adopt a new way of thinking in the post-Soviet era: a radical change of one's personality, which turned out to be unavoidable amidst the historical changes. Although the vampire tongue inhabits a vampire's body, is not the same as the vampire himself. Rather, it is a separate entity coexisting within the same body. The vampire tongue controls the vampire: it is like another living being. Being immortal, it passes from one vampire to another, creating a symbiotic duo. ${ }^{54}$ When the tongue is settling down in its new body, it can be called a second

\footnotetext{
${ }^{54}$ Viktor Pelevin, Empire V (Moskva: Eksto, 2006), 34.
} 
birth for the human, or vampire, a new incarnation for the tongue. ${ }^{55}$ Therefore, the death of Brama is necessary for Roma to enter the vampire world - it is the first seemingly sacrificial act and the first death that he faces. Roma gets a new vampire name of Rama, that of the Hindu god. ${ }^{56}$ As Pelevin's vampires consider themselves to be gods, other vampires also carry on the names of various deities, creating an eclectic mix (for example, the vampires Mitra or Brahma).

Except for god, vampires are the highest rank in this depicted society. However, vampires do not have any 'official' religion, and the question of the essence of god is generally avoided. What matters more is the correct functioning of the hierarchical system, ${ }^{57}$ and the consumption of humans' life energy, named bablos. Vampires are depicted in Empire $V$ as the chosen ones, the privileged creatures, created by the Goddess Ishtar to help her remember the meaning of life and to explain why she created this world. Accordingly, vampires created people and a system for using them for their own purposes, such as using money as a means to get their life energy. People generally do not know about the existence of this vampire society. Thus, instead of the usual performance of rituals and remedies against those undead creatures, vampires themselves perform rituals, which structure their life and help establish a certain hierarchy.

The novel Empire $V$, being the story of Rama's coming of age, in this sense can be compared to Tatarsky's story in Generation P. During Rama's new schooling his thinking is gradually transformed. Rama's transformatory period, or his extended initiatory process, is marked by three significant events. The first is the Great Fall from Grace. The second is Rama's introduction to the Chaldean society and his meeting with the Goddess Ishtar. The third is the so-called 'Red Ceremony', that is, the consumption of bablos. Rama's duel with another vampire, Mitra, is the final point of his coming of age story.

The Great Fall from Grace is a ceremony that both Rama and his new friend, the female novice vampire Gera, await with fear. In order to get to where the ceremony takes place, they have to consume a liquid which transforms them into bats. This physical transformation of their appearance metaphorically signals their mental transformation. The state of the vampire, that transformatory period from human being into the bat, is experienced in a dream-like state as a kind of death. Rama remembers that in popular culture vampires are

\footnotetext{
55 Ibid., 35.

${ }^{56}$ Full name is Ramachandra (it is one of the popular deities in Hinduism).

${ }^{57}$ In this system the hierarchy is as follows: (unknown civilization) / Ishtar, for whom this land is a prison / vampires / Chaldeans / people, being used as livestock.
} 
regarded as the living dead, and suddenly he feels the same way. ${ }^{58}$ In order to fully be immersed in this new world and new state, a person undergoing the initiation process has to die (symbolically) for his old world and give up his old beliefs, old identity, and even his body. In this case, it is done almost in a literal sense, experiencing the all-encompassing fear of death and a death-like state.

To get to a place called Heartland, where the elder vampire Enlil lives, one must dive through a hole in the earth to enter the underworld. ${ }^{59}$ This sacred place is also marked with underworld symbolism, as the vampire motto puts it, 'to the darkness, back and down'. During this ceremony Enlil reveals almost all the mysteries surrounding the vampire society to them, except one - about the origin of the bablos and its experience. Rama finds out that vampires selected and created humans as cows, desiring to consume that essence of the socalled Mind B - the humans' hopes and dreams - that energy which is directed towards what is sacred for them. ${ }^{60}$ Vampires not only take away what is truly sacred for people, but they also design that what should be sacred for them, in order to appropriate that energy, which is directed towards sacred objects. This can serve as a perfect metaphor for Soviet society or, for that matter, for any ideology, including the consumer culture and the effect of advertising - all used to manipulate people.

Pelevin's vampires consume not the blood, or 'red liquid', as they call it, but the monetary substance as a contemporary medium of the human's life energy. It comes out of human time and energy, their vital power. Money is the symbolic blood of the world, elevated to the status of a sacred substance. The understanding of the role of money can be called a true fall from grace - the abandonment of the naïve illusions. Rama also interprets this fall from grace as a belief that one can become a god. ${ }^{61}$

Another part of this extended initiatory process is the traditional gathering of both vampires and Chaldeans, who are members of the organisation that connects the world of the vampires with that of the humans. Apparently they control the power structures and do not let people escape from this magnificent scheme. Chaldean society first emerged in ancient Babylon (yet another of Pelevin's resonances of his favourite Babylonian mythology). This longing for structure and meaning is yet another time expressed and coded by him in the creation of the fictional world schemes.

\footnotetext{
${ }^{58}$ Pelevin, Empire V, 152.

${ }^{59}$ Note that it is the same motif of the underground as in Generation P, the episode with The Golden Room.

${ }^{60}$ Ibid., 345.

${ }^{61}$ Ibid., 215.
} 
Although Pelevin's vampires are depicted as relatively modern creatures, they are still surrounded by many ancient rituals, which for most of them have already lost their initial meaning. However, these rituals keep their community together and help maintain the existing social hierarchy, and at this gathering Rama has to present himself to the audience, and subsequently ritually bites one of the Chaldeans to explicitly show the power of vampires. Also, on that same evening he finally gets the chance to meet the Goddess Ishtar, the Mighty Bat. More precisely, he talks to the woman's head, which is currently Ishtar's representative. Symbolically, the goddess has a body of the bat and a head of a woman.

The third significant step in the initiatory process is the Red Ceremony, or bablos tasting. Eventually Rama and Gera are invited to experience bablos. The word bablos also comes from Babylon - it is the substance that helps vampires to become gods. ${ }^{62}$ Thus bablos is the essence of what is most sacred for people - their hopes and dreams, their striving for something that could be considered sacred. Although bablos is not itself a material substance, money still plays a symbolic role in the bablos consumption ceremony - it is ritually burned beforehand.

The moment of the consumption of bablos, although initially painful, eventually happens to be the best experience in Rama's life. It is hardly possible to describe it with words - it is an experience of the ultimate happiness and fulfilment. In a sense, it can also be called a certain sort of enlightenment, as Rama realises that all his questions have been answered, and he has finally found what he had been looking for. During the bablos experience Rama realises that he has just remembered everything:

"The same happened to me, I remember how ... I remember how that bright red drop of hope appears ... It seems that it will take just one moment for us to understand, to do, to realize something, and then another life will start, right and true. But this never happens, as the red drop of hope disappears somewhere all the time., ${ }^{63}$

Rama remembers that he had known everything when he was a child: "I saw vampires, crossing my dreams, and I understood that they are taking that what is the most important in life." ${ }^{64}$ Hopes are depicted as the most important in life, naïve and childish hopes as the sacred, which emerge in the human heart only to be sacrificed at the same moment.

And then Rama realises that he has already forgotten everything.

\footnotetext{
${ }^{62}$ Ibid., 250.

${ }^{63}$ Ibid., 346.

${ }^{64}$ Ibid.
} 
Rama's experience unambiguously reminds us of psychedelics: "Everything in the world was made of one and the same substance. And I was that substance. ${ }^{\circ 65}$ He experiences the greatest possible happiness which cannot be compared to anything else - absolute safety. This experience, as it is noted by Osiris, an outcast in the vampires' society, might perhaps be achieved during the highest levels of yogic practices. ${ }^{66}$ It can also be compared to that of psychedelics because of its temporality, illusory nature and attractiveness. Rama immediately wants to repeat it. Thus it can be regarded as different from those 'true' spiritual experiences, which supposedly have a longer lasting effect. Pelevin masterfully draws the parallels between the experiences of the monetary enlightenment and that of the so-called spiritual enlightenment. After the Red Ceremony both Rama and Gera get a badge - 'monetary god' the allusion here could not be more obvious. ${ }^{67}$

As already noted, Rama's duel with his rival Mitra is the final point of his coming of age story. Gera saves him and instead chooses Mitra to be sacrificed: the vampire's tongue is needed to replace Ishtar's head with the new one. Gera becomes the new Goddess Ishtar IV, and Rama, being her closest friend, unexpectedly becomes one of the most influential members of vampires' society. This guarantees him a safe and secure position on the top ladder of this hierarchical structure. Here, as it was already mentioned, Pelevin repeats the same scheme as in Generation P. At the end of the novel one of the characters is sacrificed and the protagonist symbolically replaces him.

After this extended initiatory process Rama admits to himself that he has changed. He has become a different person and has made his choice in favour of the vampires' world and its rules. He finally became one of them. It could be said that the thirst for bablos won against his human feelings. As Rama himself admits, a person on the top of the mountain is not the same as the one at the beginning of his journey. ${ }^{68}$

He also compares it with growing up and finally becoming an adult: "It's like this, gradually and without noticing, we become grown-ups. There comes peace and clarity - but we pay for that with our naïve faith in miracles." 69 While at first Rama is upset and disgusted to become a vampire, ${ }^{70}$ eventually he starts enjoying his new life. Together with other human

\footnotetext{
${ }^{65}$ Ibid., 348.

${ }^{66}$ Ibid., 350.

${ }^{67}$ Ibid., 351.

${ }^{68}$ Ibid., 407.

${ }^{69}$ Ibid., 408.

${ }^{70}$ Ibid., 138.
} 
beings he is striving to get to the other, happy shore, the far away horizon, where the sun, happiness, money and love await. ${ }^{71}$

The novel Empire $V$, besides being a postmodern vampire tale, is also an allegorical tale about one's growing up, conforming to society and the price that a person pays for that, namely, sacrificing a naïve faith and innocence. Sacrifice of another human being serves here as a metaphorical reflection of sacrifice of one's belief system and previous ideals. In the post-Soviet world the most important sacrifices take place in one's head. These are sacrifices of one's ideas, previous ideological systems which are no longer valid in the post-Soviet milieu.

Significant here is also the sacrificial act, during which the 'old' Ishtar's head is replaced with Gera's. One possible explanation of this act is provided by Girard. ${ }^{72}$ Ishtar's sacrifice becomes possible because she is in a sense casteless. Being at the very centre of the (vampire) society, she is also isolated from the rest of the community and does not belong to it.

Worth noting is also the fact that in order to become a goddess, Gera has to sacrifice the most important human attribute, that is, the body. Sacrificing her body Gera becomes an idea: a monetary god does not need to have an earthly embodiment. Similar motifs could also be seen in Omon Ra. In order to fly, the young pilots-to-be had to sacrifice their legs. As was already discussed in this chapter, this act served as both the repetition and imitation of a supposedly heroic act and also as a symbolic expression of the denial of an 'earthly' attribute in order to get to the sky.

\subsection{The Ultimate Transformation}

The last part of this chapter analyses the most unusual case of initiation and sacrifice in Pelevin's prose. Initiation here becomes the ultimate transgression of human powers and limits, transgressing the sacred boundaries between the human world and that of Satan and god.

This case can be found in one of the latest of Pelevin's books Pineapple Water for the Fair Lady (2011), which consists of the two parts, Gods and Mechanisms and Mechanisms

\footnotetext{
${ }^{71}$ Ibid., 146.

${ }^{72}$ Girard, Violence and the Sacred, 12.
} 
and Gods. ${ }^{73}$ As one reviewer passionately states, with the novella Operation Burning Bush (included in the first part of the book) Pelevin makes the reader fall in love with his protagonist, offering for the first time a living being, one with his authentic thoughts and weaknesses, a protagonist that is impossible to resist. Hence the difference from the previous protagonists such as Pyotr in Buddha's Little Finger or Tatarsky in Generation $P{ }^{74}$ Martin Ganin also notes that this time the protagonist resembles a human being rather than a literary construct. $^{75}$

With this novella Pelevin also comes back to his Western monotheistic roots. Eastern philosophy and the discussions on emptiness are replaced by the notions of monotheistic religions. The allusions to Western monotheism are evident already in the epigraph lines from Leonard Cohen: "I'm the little Jew who wrote the Bible.,"76

Although in this story Pelevin follows the familiar scheme when constructing the plot, the process can be named initiation only conditionally, as already mentioned in the beginning of this section. Pelevin here, as in most of his books, follows his usual path. At the beginning the protagonist is an outcast, unable or unwilling to adapt to society's norms and regulations (as Rama in Empire V, Tatarsky in Generation P, Pyotr in Buddha's Little Finger). Then he is, often against his will, involved in the activities of some secret societies/communities and eventually enters one of the leading positions in those societies.

The main protagonist in Operation Burning Bush is Semyon Levitan. From childhood he developed a passion for the voice (and the imitation of the voice) of the famous radio announcer, Yuri Levitan. ${ }^{77}$ In other words, from the early years Semyon learns to understand and appreciate the magical power of words, language and voice. Typically in Pelevin's books, the Soviet empire collapses during the protagonist's coming-of-age years. The career that the protagonist hoped for (as Tatarsky in Generation $P$ ) fails. Semyon works as an English teacher, considers himself a loser, and starts to ponder suicide as his life seems to be meaningless. As usual, Pelevin uses this opportunity to point out the specificity of the time

\footnotetext{
${ }^{73}$ The title of the book (Ananasovaya voda dlia prekrasnoy damy) is in itself an intriguing construct from the allusions to the creative works of Russian poets Vladimir Mayakovsky and Aleksandr Blok. It is also a beautiful irony, as there are hardly any fair ladies in Pelevin's world.

74 Anna Narinskaya, "Vozvrashchenije glavnogo geroya," http://www.kommersant.ru/doc/1554035 (accessed November 19, 2011).

${ }^{75}$ Martin Ganin, "Nazovu sebya Levitan," http://www.openspace.ru/literature/events/details/19226/?expand=yes\#expand (accessed November 19, 2011).

${ }^{76}$ Victor Pelevin, Ananasovaya voda dlia prekrasnoy damy (Moskva: Eksto, 2011), 4.

77 After exploring advertising and TV world in Generation P, Pelevin now enters the radio world - the last untouched territory.
} 
period he is dealing with, trying to explain and to frame this transition period between the Soviet past and the present time.

As in Generation $P$ or Buddha's Little Finger, the protagonist meets one of his childhood friends. In this case, the friend is Vlad Shmyga, who was familiar with Semyon's passion for imitating Levitan's voice. This meeting pushes Semyon's life in an unexpected direction - he is kidnapped and taken to a secret base, where he finds out what his mission will be.

Here Pelevin continues his tried and true tradition of conspiracies, intrigues, and secret schemes. The main boss Vlad Shmyga, and Dobrosvet, a sort of consultant for spiritual-esoteric questions for the organisation, briefly describe their political perspective to Semyon. Apparently, according to them, one of the most powerful political figures in the world is to be found in American right-wing politics. These people are extremely religious: "They claim to be chosen by God exclusively on the grounds of their faith that they were chosen by God." ${ }^{78}$ One of such figures is the (now former) president of the United States George Bush. Semyon is told that now he will be trained to properly imitate the voice of god for Bush in order to persuade him to make favourable decisions. ${ }^{79}$ This voice is now possible to transmit as Bush has undergone a dental treatment during which he was transplanted with a special filling. Semyon got the same filling as well. There will also be angel voices to give more detailed directions to Bush. ${ }^{80}$ The initiation process is unusual in this case because humans strive to literally become god. ${ }^{81}$ Pelevin no longer limits himself granting his protagonist the highest position in one of the imaginary societies and creates a Deus ex machina.

Semyon could be named as one of those 'spiritual but not religious' types of people. As he puts it, he believes that there is some power, although he does not go to any church or synagogue. ${ }^{82}$ In order to fully acknowledge his new position and to be suggestive enough in his expression of the voice of god, he has to undergo a theological course. Excerpts from various sacred, philosophical, theological texts including, but not limited to, Martin Buber, Meister Eckhart, and Krishna, are mixed with the various combinations of psychedelic

\footnotetext{
${ }^{78}$ Ibid., 15.

${ }^{79}$ Hence the title Operation Burning Bush is not only a biblical allusion, but also an allusion to the president's family name.

${ }^{80}$ Apparently Pelevin was familiar with the notorious Bush's statements that god speaks through him. For example, in Julian Borger, "How Born-Again George Became a Man on a Mission," http://www.guardian.co.uk/world/2005/oct/07/usa.georgebush (accessed February 21, 2012).

${ }^{81}$ Ironically, the two crucial elements for this transformation are Jewish ancestry and fluent English.

${ }^{82}$ Pelevin, Ananasovaya voda dlia prekrasnoy damy, 14.
} 
substances (the main ingredient being LSD) to get a mystical experience necessary for one to feel god's presence, and to eventually become a god. ${ }^{83}$ All these preparations take place while Semyon is in a sensory deprivation tank, filled with warm salty water. According to Dobrosvet, "All religions and spiritual teachings disagree for many reasons, but they all claim that to explain to a human that what is God is impossible. ... It is possible only to experience God." ${ }^{, 4}$ Thus in the darkness of the sensory deprivation tank, while not being able to see anything or to feel his body, and under the effect of drugs, Semyon attempts to have the experience of god. ${ }^{85}$

Here, the direct allusion to the importance and significance of psychedelic substances can be noticed. In Generation $P$ Tatarsky experiments with LSD and fly-agarics only partially realising what it is that he is searching for. As he claims later, "I'll never eat any of that junk again. I ... I only want to be happy, and I just can't manage it." ${ }^{~}{ }^{26}$ In Buddha's Little Finger this experimentation also resembles a childish game, as Baron Jungern puts it, of "petty hooligans high on shamanic mushrooms." ${ }^{87}$ However, in Operation Burning Bush the psychedelic substances are used purposely for expanding awareness and inducing mystical experiences.

The novella evolves as a story about the ultimate human transformation - becoming god. The more Semyon learns about god the less he knows about him, as he gradually realises. During one of these séances Semyon experiences the moment, which could be conditionally named the enlightenment moment - he realises that he is a free mind that can become what it wants. ${ }^{88} \mathrm{He}$ realises the ultimate emptiness ("There is no Semyon Levitan, only the fathomless"), ${ }^{89}$ the non-duality ("You and Him - one"). ${ }^{90}$ As he realises, god has an uncountable number of faces. ${ }^{91}$ Semyon becomes addicted to those experiences as these are the experiences of bliss, which are beyond any possible description. His personality is thus

\footnotetext{
${ }^{83}$ For the better effect, various people are invited and asked to say something about god - thus the clergyman would quote his sacred scriptures, the artist would read poetry, etc. (Ibid., 19.)

${ }^{84}$ Ibid., 18. Here again, the resemblance to Rudolf Otto's arguments of the sacred is evident.

${ }^{85}$ The theoretical background concerning psychedelics was already presented in the second chapter. The role of psychedelics in Pelevin's prose is further discussed in the sixth chapter. In this particular case, it is useful to remember the Good Friday experiment (Paula Jo Hruby, "Unitive Consciousness and Pahnke's Good Friday Experiment," in Psychoactive Sacramentals: Essays on Entheogens and Religion, ed. Thomas B. Roberts (San Francisco: Council on Spiritual Practices, 2001), 58-68.)

${ }^{86}$ Pelevin, Homo Zapiens, 123.

${ }^{87}$ Pelevin, Buddha's Little Finger, 222.

${ }^{88}$ Pelevin, Ananasovaya voda dlia prekrasnoy damy, 23.

${ }^{89}$ Ibid.

${ }^{90}$ Ibid., 24.

91 Ibid.
} 
transformed. Dobrosvet claims that "according to all indicators you have to be a different person now. 92

However, the real horror for Semyon starts later, when he finds out that the US Secret Service uses similar methods against the leaders of the former Soviet Union and now Russia. In this case, ironically, they are imitating the voice of Satan. Hence Semyon has to undertake this task as well. ${ }^{93}$ This scary task might be interpreted as merely a metaphor for an inevitable fate of a person who tries to take over the role of god. But this is not Pelevin's moralisation. This is a sad irony and, curiously, Pelevin's genuine sorrow for all sentient human beings, torn between the duality of good and evil. ${ }^{94}$

Getting ready for Satan's role is even more torturous and terrifying. It is like a glimpse into the scariest parts of human's soul. As Semyon notes, "it's not that my thinking has been changing greatly, no. It just ceased to be mine - and thinking at all.",95

He ultimately 'becomes' Satan a few days later, followed by the death of Dobrosvet. Here Pelevin presents the familiar scheme of sacrificing one of the characters of the story. However, this plot does not end with the main protagonist becoming a leader of a certain community or society. Semyon is betrayed and kidnapped by another secret service group, which is based in Israel. ${ }^{96}$ Thus he fails to escape the system although he holds an important role in that system. At the same time he is powerless and without a definable future, or any ability to choose freely. As Americans experiment with new combinations of psychedelics, Semyon experiences slightly different visions, out of which it is worth mentioning his vision of becoming a burning bush. ${ }^{97}$ Work in this place brings Semyon the final disillusionment with the world of dualities, and with Judeo-Christian religious traditions. As a final farewell to monotheistic traditions, Semyon starts experimenting with various forms of meditation, eventually deciding to deepen his practice of Vipassana meditation:

"I practice Vipassana for my soul, and in this road I have never met god or Satan. This, beyond doubts, makes me glad, because I have enough of that goodness at work." 98

\footnotetext{
92 Ibid., 27.

${ }^{93}$ Hence Satan dictated the directions for Stalin, Beria and their ilk.

${ }^{94}$ This is also an unambiguous Pelevin's opinion about the nature of the political decisions in his country.

${ }^{95}$ Ibid., 43.

${ }^{96}$ Ironically this sacred land serves as a place for Semyon's enlightenment, as working for Americans he discovers the Eastern spiritual traditions.

${ }^{97}$ While being in this state he can be visible to those who are under the effect of psychedelic drugs. Pelevin here masterfully inserts an allusion to an episode of Tatarsky's acid trip in Generation P. (Pelevin, Ananasovaya voda dlia prekrasnoy damy, 55.)

${ }^{98}$ Ibid., 58.
} 
From this analysis several reasons can be seen of why Semyon was chosen for the role of god. Not only because he could perfectly imitate the voice of Levitan (speaking English with a Jewish accent), but also, and perhaps most importantly, because he was a person lost in transition, and typically in Pelevin's prose, the one that had nothing to lose. Although he was promised a million dollars, money here plays a secondary role. First of all, Semyon does not have any real opportunity to refuse his task and, secondly, he gets addicted to his godly experiences. Therefore, not Dobrosvet, but Semyon appears to be the actual victim of this drama.

Although Pelevin dedicates this book to the monotheistic tradition, the ending of the book unambiguously points out his sympathies to Eastern traditions and brings the reader back to the concepts of emptiness and liberation. These notions are once again shown as the only possible solutions of this earthly life that can be offered after the ultimate horror of the protagonist's fate:

"If everything is all right, soon I will enter the Stream and stop the emergence of the phenomena. ... Or perhaps even while still living I will become an Arhat, who will never have to come back to this gloomy valley of meanings and passions. And if this happens, with all my soul, with all my broken heart I believe that God will forgive me - as I forgive him." 99

From the world of dualities (god-Satan, Soviet Union-United States, KGB-CIA) Pelevin is striving towards the non-dual. This non-traditional initiation here becomes stepping over the threshold into the non-dual world, one step closer to the imaginary Optina Pustyn. ${ }^{100}$

\subsection{Conclusions}

This chapter discussed the conventional modes of the sacred. As it could be seen from these five examples, the analysis of initiation and sacrifice can serve as a tool to disclose the new structures of the sacred unfolding in post-Soviet literature. The theoretical assumptions, presented in the second chapter, helped to track the traditional features of the initiation processes: entering the liminal state, sacrifice, finding out the truth about the real structure of

\footnotetext{
${ }^{99}$ Ibid.

${ }^{100}$ The notion of Optina Pustyn is further described in the seventh chapter.
} 
a group or society, or discovering the meaning of existence. Initiation processes illustrate the state of the post-Soviet people, lost in transition between different epochs. The ritual theory also helped by noting that the liminal, or threshold times and spaces (in some cases) empower the changes, facilitating transformation/initiation and moving onto another level of consciousness. It could also be seen that sacrifice, as well as the concept of the sacred, is to be treated as ambiguous, dynamic and changing. Instead of sacrificing for a transcendent deity, here sacrifice is meant to establish the power of the monetary sacred (Generation $P$, Empire V, partly Operation Burning Bush). Sacrifice can ensure and reaffirm the new protagonist's position in society. Sacrifice can also gain a new meaning, that is, the sacrifice of one's ideals in order to become a powerful figure in certain communities or societies.

However, with his depiction of initiation and sacrifice, Pelevin also deconstructs the traditional understanding of these notions. What could be seen from the examples provided in this chapter are failed promises of initiation as a necessary step en route through the transition to the higher level. In a sense, initiation fails to happen, it is a simulation of initiation (as in Omon Ra, Generation P). This failure reminds us of the state of the post-Soviet people as portrayed by Pelevin, consciously or unconsciously refusing the changes that took place during the break-up of the Soviet structure and hence refusing to move forward to the final stage, that is, reintegration into the new structure. Thus sacrifices, always required and performed, also appear to be purposeless (especially vividly expressed in Omon $R a$ ). The sacrificial mechanism is presented as false and fabricated.

This finding encourages revisiting the theoretical assumptions about the ritual, as presented in the second chapter. Even though their value is unquestionable, Pelevin's prose also demands an additional rethinking of the theories in order to better understand the world created in his works. By creating his own interpretation of rituals and inventing new forms, Pelevin redefines the sacred in contemporary society, trying to explain and frame the 'absurd and scary' world. At the same time, this is evidence of the relativity and temporality of the sacred.

These cases clearly illustrate the main themes of Pelevin's prose: the deconstruction of Soviet mythology and what was held sacred, the deconstruction of the post-Soviet, or consumer society, and the monetary sacred. Both modes of the sacred prove to be no longer satisfactory. However, as already noted, after deconstruction the upcoming void can serve as a productive ground for the search of new forms of the sacred. Denying the false premises can be a suitable starting point for the analysis of Pelevin's sacred. This deconstruction gesture in the search of the sacred can prove to be useful. 
The subsequent chapters further explore Pelevin's postmodernist game between the Buddhist notion of emptiness and Western nihilistic approaches. These chapters try to distinguish whether his notions of relativity and impermanency come from the philosophy of nihilism or Buddhist ideas, or whether he is staying in-between these two approaches. Ultimately, this research attempts to explore what role the notions of escape (from the world, where the authentic choice of the sacred is no longer possible), emptiness and liberation play in Pelevin's search for the sacred. 


\section{Chapter 6:}

\section{The Sacred as Escape in V. Pelevin's Prose}

This research has classified the manifestations of the sacred into the conventional and non-conventional. While the previous chapters discussed the conventional modes of the sacred, this chapter analyses the non-conventional modes or, as they have also been named in this research, the modes of escape. It explores how psychedelic substances, alcohol, and immersion in TV-mediated reality can be employed in the search for the sacred. For a significant number of post-Soviet people, these modes of escape can be seen as an effort to abandon their negatively perceived and no longer satisfactory reality and attempt to experience a different reality. These attempts reflect the increasing trends of individualisation in the post-Soviet society, openness to experimentation (as opposed to the stagnant Soviet state), and the increasing desire to dismiss the traditional norms and conventions of society thus denying the 'old sacred'.

This chapter discusses three modes of escape as seen in Pelevin's novels Generation $P$ and Buddha's Little Finger. First, it is the use of psychedelics, such as LSD (depicted as the (pure drug') and Amanita muscaria, or fly-agarics, and to a certain extent - the use of cocaine. Secondly, it is the use of alcohol, closely intertwined with the sense of nostalgia. Thirdly, it is an escape into the reality mediated by TV. ${ }^{1}$ Special attention will be paid to the use of psychedelics as the most illustrative form of escape. ${ }^{2}$ The theoretical background concerning psychedelics was already presented in the second chapter. To avoid repetition, it should just be emphasised that it is crucial to regard both the recreational and spiritual use of psychedelics as equally important for the discourse of the sacred. Therefore, this chapter will first analyse the intention: whether the person searching for an escape by any means intended to achieve what can be constituted as the sacred - be it through psychedelics, alcohol or TV.

\footnotetext{
1 To a certain extent, the experience of bablos, discussed in the fifth chapter, also resembles that of psychedelics.

${ }^{2}$ Although Pelevin's Operation Burning Bush serves as an illustrative example of the use of psychedelics to not only expand consciousness, but to literally become god, this text will not be analysed in this chapter. Semyon's use of psychedelics is involuntary and cannot be considered as his own, personal striving for escape. (Nevertheless, this example proved to be important when exploring the notions of initiation and sacrifice, therefore it was discussed in the fifth chapter.)
} 
Secondly, it will analyse the outcome: whether the person intentionally or unintentionally achieved that, which can be regarded as the experience of the sacred.

Although Russia has had a rich history of psychedelic mushroom use, ${ }^{3}$ the Soviet Union in general hardly experienced the surge of the spiritual searching and psychedelic experimentation during the 1960s (and the rave culture, which started from the late 1980s) in the same way as those living on the other side of the Iron Curtain. It was only after the breakup of the Soviet Union that people, especially the young generation, became more broadly and intimately acquainted with Western culture and, subsequently, the counterculture. During the post-Soviet years narcotics rapidly started to replace alcohol, with marijuana as the most popular drug while heroin was a close second, as mentioned in the third chapter. Jarrett Zigon notes that it was estimated that Russia had four million active drug users in 2004, one of the highest percentages of drug users in the world, with alcohol consumption slightly dropping. ${ }^{4}$ During this period, those experimenting with psychedelic substances wanted to experience everything at once, hence both so-called recreational and spiritual use is closely intertwined. The code words here are not only experimenting, but also escapism, as was already mentioned. Thirst for new experiences, a need to escape to the 'other' world (be it a symbolic union with the Western world, a world created in the psychedelic visions, or a need to escape post-Soviet reality) - these were the main issues that psychedelics were supposed to answer.

The notion of escape also has a special relation with that of nostalgia. As discussed, after the break-up of the Soviet Union people found themselves in the zone of liminality between the past forever lost and the future yet unknown. In this fragmented world of complete disorder, some of them attempted to return to that lost state (which might be interpreted as childhood, innocence, knowledge) by various means, including alcoholic intoxication. Nostalgia in this case can also be regarded as an attempt to regain the lost sense of identity, meaning and truth, and the sense of belonging to the community - all this is closely intertwined with the experience of the sacred..$^{5}$ The next sections will concentrate on the role of psychedelic substances in Pelevin's prose.

\footnotetext{
${ }^{3}$ Such as Siberian shamanistic tradition. More in Dobkin de Rios, Marlene. The Wilderness of Mind: Sacred Plants in Cross-Cultural Perspective. Beverly Hills: Sage Publications, 1976; Wasson, R. G. and V. P. Russia, Mushrooms and History. 2 vols. New York: Pantheon, 1957.

${ }^{4}$ Zigon, Making the New Post-Soviet Person, 13.

${ }^{5}$ This notion will be discussed in section 6.5 .
} 


\subsection{The Sacred Trip to Babylon}

The novel Generation $P$ can be named not only as an ironic account of the post-Soviet life and the emerging consumerism, with the odd excurses into Mesopotamian mythology, but also as Tatarsky's psychedelic trip. Tatarsky is introduced to the mind-altering substances by his old friend Gireiev, who offers him tea with fly-agarics. Gireiev presents himself as the embodiment of a typical Westerner (in this case, a former Soviet person), fascinated by Eastern culture: dressed in "a light-blue cassock with a Nepalese waistcoat covered in embroidery worn over the top of it." ${ }^{, 6}$ While it is Tatarsky's first encounter with psychedelics, it is also clear that Gireiev is not a novice and uses mushrooms purposely to expand consciousness:

“... For instance, that sheet of paper hanging in the obvious place on the wall - there was a letter written on it, maybe Sanskrit, maybe Tibetan, resembling a dragon with a curved tail.

'What's that?' he asked Gireiev.

Gireiev glanced up at the wall. 'Hum,' he said.

'What d'you need it for?'

'That's how I travel.'

'Where to?' asked Tatarsky.

Gireiev shrugged. 'It's hard to explain,' he said. 'Hum. When you don't think, lots of things become clear.",

It is easy to recognise the influence of the Eastern philosophy in this episode, although the exact sources from which Gireiev draws inspiration remain blurred. Gordon R. Wasson conjectures that Indian Soma (a psychoactive plant visualised as a deity, mentioned in the Rig Veda) can be identified as Amanita muscaria or the fly-agaric mushroom (mukhomor for Russians). ${ }^{8}$ Long before the Siberians were introduced to alcohol, fly-agarics were a sacred element in the shamanic rites of many tribes in northern Siberia. ${ }^{9}$ Wasson also notes the special relation that the Slavs hold with mushrooms in general, as opposed to, for

\footnotetext{
${ }^{6}$ Pelevin, Homo Zapiens, 29.

${ }^{7}$ Ibid., 31-32.

${ }^{8}$ Gordon R. Wasson, Soma, Divine Mushroom of Immortality (New York: Harcourt Brace Jovanovich, 1968), 10. He also notes that Soma is the only plant that man has ever deified. (Ibid., 3.)

${ }^{9}$ Ibid., 10 .
} 
example, Germanic and Celtic people, "infected with mycophobia." ${ }^{10}$ However, Wasson's identification of Soma with fly-agarics is contested. ${ }^{11}$

Tatarsky's experience with fly-agarics is pleasant and thrilling. As Tatarsky later confesses to Gireiev, after mushrooms he felt as if he had come back home. ${ }^{12}$ However, the pleasant physical feelings caused by fly-agarics tea appear not to be enough for Tatarsky. He wants to intensify that experience and hence eats several more fly-agarics behind Gireiev's back when both of them go for a walk. Only afterwards, in the course of a pseudophilosophical conversation with Gireiev about death, Tatarsky notices that "thinking had become difficult and even dangerous, because his thoughts had acquired such freedom and power that he could no longer control them."13 In his strange psychedelic visions he starts seeing "his own mind: it was a white sphere, like a sun but absolutely calm and motionless. Dark, twisted fibrous threads extended from the centre of the sphere to its periphery. Tatarsky realised that they were his five senses." 14 That is how he realises that there is no death: "... because the threads disappear, but the sphere remains!"15

However, Tatarsky also experiences the side-effects of fly-agarics. The inability to understand each other was the reason why, according to the biblical account, people could not finish building the Tower of Babel. The myth of the confusion of languages is also reflected in Tatarsky's inability to pronounce words correctly (as a consequence of taking fly-agarics). Hence Gireiev eventually runs away from him scared. This is how Tatarsky interprets it himself:

\begin{abstract}
"'Why, of course, it's the Tower of Babel!' he thought. 'They probably drank that mushroom tea and the words began to break apart in their mouths, just like mine. Later they began to call it a confusion of tongues. It would be better to call it a confusion of language ...",16
\end{abstract}

The biblical motifs here closely intertwine with Mesopotamian history and mythology, as it is likely that the biblical story of the Tower of Babel was influenced by the ziggurat in the city of Babylon. Pelevin masterfully juggles both Mesopotamian and biblical

\footnotetext{
${ }^{10}$ Ibid., 180-181. That is how he describes his personal experience: "We found that the northern Slavs know their mushrooms, having learned them at their mother's knee; theirs is no book knowledge. They love these fungal growths with a passion that, viewed with detachment, seemed to me a little exaggerated." (Ibid., 173.)

${ }^{11}$ Huston Smith, Cleansing the Doors of Perception: The Religious Significance of Entheogenic Plants and Chemicals (New York: Jeremy P. Tarcher/Putnam, 2000), 57-60.

${ }^{12}$ Pelevin, Homo Zapiens, 32.

${ }^{13}$ Ibid., 33.

${ }^{14} \mathrm{Ibid}$

${ }^{15}$ Ibid., 34 .

${ }^{16}$ Ibid., 36-37.
} 
references, creating a mix that is ultimately Pelevin's own unique mythology. ${ }^{17}$ The flyagaric experience is also closely intertwined with the role of Ishtar in Pelevin's texts. Tatarsky accidently finds a binder entitled TIKHAMAT-2, which could be regarded as a sort of a pseudo-scientific treatise, and an article "Vavilon: tri khaldeiskie zagadki"18 in it. The mythology presented in this material is later reflected in his psychedelic visions, becoming an important part of the novel. Among other things, this material states that, besides the mirror and the mask that are the ritual elements of Ishtar, the third ritual requisite is the fly-agaric mushroom, presuming that its cap is "a natural map of the starry sky" and in general it is the "heavenly mushroom referred to in various texts."19

This article also summarises an ancient challenge: whoever succeeds in ascending the Tower of Babel and in answering the three riddles of Ishtar wins a prize of a sexual union with the goddess. Hence Tatarsky follows the challenge and after his adventures in the woods with fly-agarics he finally finds himself near an unfinished and abandoned Soviet building: a tower that resembles a Babylonian ziggurat (another reference to Babylon). Here it can be argued that Tatarsky's journey, which finally ends in his position as the ritual husband of the Goddess Ishtar, actually began with this first encounter with fly-agarics.

The main figure of Tatarsky's version of Mesopotamian mythology, as mentioned, is the Goddess Ishtar, depicted as a symbolic representation of the 'monetary sacred', a goddess of consumerism. Becoming the ritual husband of the goddess, Tatarsky also becomes the head of a media corporation and Chaldean Guild, which controls all TV production, and subsequently establishes his position as a god for the consumer society. This also signifies the deification of advertising and its role in forming people's beliefs and values.

One of Tatarsky's links with Ishtar and one of the reasons why he actually became 'the chosen one' was his name, which resembles the name Babylon. ${ }^{20}$ Another reason was his role as a copywriter in the post-Soviet society. In terms of the monetary world, this role resembles the prophet's. The Soviet people, long accustomed to the one idea of truth without question, were shocked and overwhelmed by the multitude of truths and goods that flooded in after the break-up of the Soviet Union and bombarded them with seductive advertising images. With no experience of having the right to choose and to question, they found it hard to examine those truths critically and not to trust everything that they were being told. They

\footnotetext{
${ }^{17}$ Also, a reference to the use of psychedelic substances here unambiguously points to the Siberian shamanistic tradition. This is yet another example how Pelevin re-interprets Western tradition and 'translates' it into Russian. In a sense, Pelevin's understanding of the Bible is a somewhat Russified version.

18 "Babylon: Three Chaldean Riddles."

${ }^{19}$ Ibid., 26.

${ }^{20}$ The change of the names in the translation (Vavilen/Babylen) was already mentioned in the fifth chapter.
} 
had yet to switch from the notion of the universal and eternal truth to the many individual, temporary, and questionable truths (and sacreds). In such a milieu, the words of the copywriter could be regarded as the words of a new prophet - the messiah of the monetary sacred - as the copywriters were forming the beliefs for the masses. Therefore, Tatarsky became such a prophet even before his initiation into the role of the monetary god.

There is one more possible interpretation of Tatarsky's 'marriage' to the Goddess Ishtar, that of the Siberian shamanistic tradition. During a special ritual, the Siberian shaman must 'marry' a game-giving (or fish-giving) spirit's sister or daughter, and only as a husband is he entitled to "rightfully obtain promises of game (or of fish) from his spiritual wife: his legitimacy as shaman comes from his marrying a spirit." ${ }^{21}$ Therefore, Tatarsky's symbolic union with Ishtar can be understood as granting him a right to use the material goods and his attachment to the monetary sacred.

After the episode with fly-agarics, abandoned by his friend Gireiev, Tatarsky is left on his own to fight with the invisible demons of his mind. Being obsessed with the idea of Babylon, Tatarsky then discovers the 'gates to the Tower of Babel' in an abandoned building site, similar to many in the post-Soviet era. While climbing the tower, Tatarsky finds three objects that he might interpret as the three riddles of Ishtar; namely, a pack of Parliament Menthol cigarettes with an advertising hologram showing three palm trees, a Republic of Cuba three-peso coin with a portrait of Che Guevara, and a pencil sharpener in the shape of a TV. All three objects act as certain hints. From further events it is clear that these objects point to: the advertisement of the Parliament cigarettes; Che Guevara, speaking out of an Ouija board; and to the role of TV in Pelevin's depicted society. In other words, these objects point to the role of advertising, the monetary power, and the impact of TV on contemporary society. However, the three riddles do not necessarily have to be understood in the purely literal sense of the word. The three riddles of Ishtar can be linked to three of Tatarsky's encounters with psychedelics. The first encounter is the fly-agarics experience in Gireiev's house, when Tatarsky ran to the unfinished tower. The second adventure with LSD ended with a scared-to-death Tatarsky praying to god. This episode will be discussed in the next sections. The third (and final) encounter took place again by the unfinished tower after the consumption of fly-agarics, just prior to Tatarsky's initiation into the secret Chaldean Guild.

\footnotetext{
${ }^{21}$ Shamanism: An Encyclopaedia of World Beliefs, Practices, and Culture, vol. II, ed. Mariko Namba Walter and Eva Jane Neumann Fridman (Santa Barbara, Calif.: ABC-CLIO, 2004), 621. Another interesting feature of this ritual is a divinatory sequence, during which the shaman determines the supposed life expectancy of the participants. Then "any subsequent death will be interpreted in terms of payment to the spirits, like the old hunter's 'voluntary death': it is necessary that some members die for the group to survive." (Ibid., 622.) This feature can shed light into another interpretation of Azadovsky's death.
} 
The three riddles also signify Tatarsky's trip from being a modest Soviet poet, to a kiosk salesman and on to a 'living god' and, overall, this marks Tatarsky's extended initiatory process into the world of the monetary sacred.

\subsection{The Tale of Three Towers}

"If it had been possible to build the Tower of Babel without ascending it, the work would have been permitted."22

Tatarsky's obsession with the Tower of Babel can signify the desire to return to that state of innocence, when "the whole earth had one language and the same words." 23 The creation of the Tower of Babel marks the endless and eternal attempts to resolve the mysteries of the universe, to build "a tower with its top in the heavens" (Gen 11:10-11). Such fictional attempts by Pelevin for the 'restoration' of the Tower of Babel can be interpreted as signifying the desire to return to the old sacred, a kind of nostalgia for the times lost. By presenting a postmodernised version of the Tower of Babel's re-creation, Pelevin not only demonstrates the painful longing for transcendental knowledge - those reliable explanations of the meaning of life and the purpose of this universe - but also by depicting the contemporary Tower of Babel as the Ostankino TV Tower or an unfinished Soviet building, he shows that the link with transcendence, or the past, is forever lost. It also serves as an illustration for the deconstruction of the 'old sacred'.

Moreover, the image of the tower, or ziggurat, helps Pelevin draw a parallel between contemporary Moscow and ancient Babylon: a parallel, which also marks his eschatological moods and the feeling of temporality, and serves as a reminder that the once glorious Moscow may one day fall into ruins as well. This is evidently expressed in the image of the five-legged dog Pizdets, ${ }^{24}$ the embodiment of chaos and destruction, which is apparently dormant somewhere in Russia. All these motifs curiously resemble the notion of the whore of Babylon, a Christian allegorical figure of evil representing hell on earth. These parallels intertwine throughout the novel, creating Pelevin's image of Russia as the place for hell on earth.

\footnotetext{
${ }^{22}$ Franz Kafka, Parables and Paradoxes (New York: Schocken Books, 1961), 35.

${ }^{23}$ Gen 11:1-2. In this thesis, all biblical quotations are from the New Revised Standard Version (New York: American Bible Society, 1989).

${ }^{24}$ This name means a Russian multi-purpose obscenity, translated by Andrew Bromfield as 'Phukkup'.
} 
To sum up, the three images of the towers can be distinguished in the novel Generation P. First, it is the Tower of Babel, the story which is included in the material read by Tatarsky. Then, it is the unfinished tower, a relic from the Soviet past, which seemingly serves as a kind of a 'sacred space' - a space for Tatarsky's psychedelic adventures. Finally, it is the Ostankino TV Tower, which serves as a sacred space for the monetary sacred, associated with TV, power and the Chaldean guild. Pelevin connects all these worlds in the episode at the abandoned site when Tatarsky finds a newspaper with the TV programmes for the week. ${ }^{25}$ There he sees the title of the programme, 'The Golden Room', where he is actually going to participate shortly afterwards. This room is the place some 100 metres underground, near the Ostankino pond, where Tatarsky's initiation into the world of the monetary sacred will later take place. Hence he is already on TV in a metaphorical sense, even before he actually became the ritual husband of Ishtar. For Tatarsky, both these towers represent the Tower of Babel and are thus symbolically united.

The unfinished state of the abandoned tower symbolically reflects Tatarsky's own unfinished state. Potentially, this might be the reason why he is so attracted to that place. The unfinished tower serves as a memory left behind from the former Soviet Union, from the previous space and time, where everything seemed to be clear, simple and seemingly safe. Tatarsky himself is unfinished, in a liminal state, born and raised in the system that eventually disappeared overnight, leaving him with no skills to adapt to the new forming system. Being unfinished, the tower can also be seen as a liminal space, in-between the old system and the new, between the earth and the sky, which becomes a missing link between everyday reality and the visions of another world induced by psychedelics. This tower also serves as a relic of the old sacred, which can no longer function in the post-Soviet milieu.

The unfinished tower (together with the drug-induced state of mind) also allows Tatarsky to notice that, "the infinite height of the sky, forgotten already in childhood, was suddenly visible again." ${ }^{, 6}$ Moreover, then he suddenly experiences a certain sense of déjà vu:

"Something trembled in Tatarsky - he recalled that once the ephemeral celestial substance of which these white mountains and this tower consisted had also been within him. And then - long, long ago, probably even before he was born - it had cost no effort at all for him to become such a cloud and float up to the very summit of the tower." 27

\footnotetext{
${ }^{25}$ Pelevin, Homo Zapiens, 228.

${ }^{26}$ Ibid.

${ }^{27}$ Ibid.
} 
That is, Tatarsky actually remembers a certain transcendental feeling, being and knowledge that is now lost, abandoned as the tower itself. It might be loosely associated not only with a state of nostalgia for the past, but also with the childhood world. Childhood here can be regarded as an innocent sacred space that is lost and might now be accessible only through psychedelic experiences. Nostalgia for childhood in this case can be extended into nostalgia for the Soviet past and its predictable safety. ${ }^{28}$

Not accidently, childhood here holds such a significance. The 'father' of LSD, Albert Hofmann, emphasises that the discovery of this substance cannot be called purely accidental, also claiming that there was a sort of a transcendental force behind it: "LSD is not a product of planned research. I did not look for it, it came to me. This means to me that a higher authority thought it was necessary now to provide mankind with an additional pharmacological aid for spiritual growth." ${ }^{29}$ Moreover, further he compares LSD-induced experiences with childhood experiences:

"In my childhood I experienced spontaneously some of those blissful moments when the world appeared suddenly in a new brilliant light and I had the feeling of being included in its wonder and indescribable beauty. They remained in my memory as extraordinary experiences of untold happiness, but only after the discovery of LSD did I grasp their meaning and existential importance." 30

This description resembles that of Tatarsky's experience when he wandered around the unfinished tower under the effect of fly-agarics and noticed "the infinite height of the sky." This is also reminiscent of a non-dual state that is possible to reach with the help of psychedelics. Both Hofmann and Pelevin here speak of the experience of non-duality, when the ego ceases to exist, that is, there is no distinction between oneself and the outside world. This non-dual mode will be further discussed in the seventh chapter.

\footnotetext{
${ }^{28}$ The Soviet times were already compared to the childhood time in the previous chapters. More about nostalgia - in section 6.5.

29 Albert Hofmann, "LSD as a Spiritual Aid," in Psychoactive Sacramentals: Essays on Entheogens and Religion, ed. Thomas B. Roberts (San Francisco: Council on Spiritual Practices, 2001), 121.

${ }^{30}$ Ibid., 123.
} 


\subsection{The Double Life}

"Which is true, the picture of the world as we perceive it with our everyday consciousness or the overwhelming image under the influence of entheogens?",31

Pelevin constantly returns to the problems of the two realities, be it the dichotomy of the reality/fantasy, the reality/psychedelic experience, or the reality/artificial TV world. However, he does not make any value judgments between these worlds and realities. All his fictional realities have equal rights to exist in his books. In the novel Buddha's Little Finger, Pyotr lives in two different worlds, and there is no clue to show which of those two worlds is 'real'. ${ }^{32}$ In the novel Generation $P$, Tatarsky searches for another reality while experimenting with LSD. Therefore, I would argue that, apart from being an overwhelming hallucinogenic experience, LSD in Pelevin's books also serves as a means for enhancing that dichotomy of dual realities and the double life. LSD is one of the means for Tatarsky to experience another life. Another means to experience this double life, as Pelevin notes, is being on TV. ${ }^{33}$

It is interesting to note one important difference between the two protagonists, Tatarsky (Generation P) and Pyotr (Buddha's Little Finger). While Tatarsky uses every possible drug that he can get, including stimulants (cocaine), psychedelics (LSD, fly-agarics) and, of course, alcohol, Pyotr just snorts cocaine and drinks excessively (although he tries a new combination of these two: vodka with cocaine ('Baltic tea') and, in his parallel life, vodka with the modern drug Ecstasy). One possible interpretation for this is that Pyotr is a kind of a split, schizophrenic personality, who in a sense already lives in the two worlds, in a boundary state between the real experience and the hallucination, whether a consequence of a schizophrenic disorder or just Pelevin's trick to explicitly show the blurred boundaries between the real and the imagined. Hence there is no need to further expand his experiences with the help of psychedelics. In Buddha's Little Finger, Pyotr's conversations with Chapayev act as a substitute for the use of psychoactive substances. During these conversations Pyotr actually realises the true nature of the universe and emptiness. Moreover, while finding himself in one of his parallel worlds, that of the $20^{\text {th }}$ century's beginning, Pyotr is even able to travel with Baron Jungern into Valhalla, the land of the dead. In this space he encounters the company of Volodin, Shurik and Kolyan, who all arrived there with the help

\footnotetext{
${ }^{31}$ Ibid., 121.

${ }^{32}$ Although eventually this guess is not so important, as the world which seemed to be more 'real' also appears to be created by the character of the book, Kotovsky.

${ }^{33}$ Pelevin, Homo Zapiens, 204-205.
} 
of psychedelics. The author does not raise the question, which of these realities is more 'real'. Moreover, for him this is not an important question. The reality itself becomes irrelevant, as it is only consciousness perceiving this reality that can be important.

In one of his interviews, Pelevin also mentions that constant thirst for 'another life'. According to him, this need can be reflected in the act of writing, which is a chance to experience the multiple lives in one: "Life is a bitch, and then you die. Death is a bitch, and then you are born. Writing is very much like this, as it is living multiple short lives within your longer one." 34

In archaic societies as well as today, the ceremonial use of psychedelics (for example, peyote in the Native American Church or ayahuasca for União do Vegetal) is restricted to certain times, places and occasions. This consumption itself is considered a sacred act, and being in an intoxicated state is interpreted as a sacred experience, allowing communication with the spiritual world. In the novel Generation $P$, this idea is repeated by a drug pusher Grigory, who Tatarsky accidently meets at the bar. Grigory has the appearance of the typical former hippy with a large bronze cross on his neck, a liminal person described as "one of those who had failed to find a place for themselves either in the past or in the present.",35 Attempting to persuade Tatarsky to buy drugs, Grigory claims that he should choose LSD and not cocaine if he wants to use drugs: "Nothing but LSD. Only via the gut and always with a prayer." 36 That is, Grigory holds the idea that taking LSD should be regarded as a spiritual experience, hence the role of the prayer.

However, the contemporary use of psychedelics does not necessarily involve creating a ceremonial environment and treating them as sacred and set apart. Thus Tatarsky's first LSD experience happens without any special preparation, in the casual environment of his flat, followed by his reading of the material about Enkidu, a central hero in the ancient Mesopotamian Epic of Gilgamesh. Tatarsky reads it while waiting for the effect of the psychedelics and suddenly realises that:

"It wasn't the sun that was reflected in the puddle, but the other way round; everything and everybody else - the street, the houses, the other people and he himself - were all reflected in the sun, which was entirely uninterested in the whole business, because it wasn't even aware of it." 37

\footnotetext{
${ }^{34}$ Leo Kropywiansky, interview with Victor Pelevin, http://bombsite.com/issues/79/articles/2481 (accessed April 18, 2011).

${ }^{35}$ Pelevin, Homo Zapiens, 54-55.

${ }^{36}$ Ibid., 56.

${ }^{37}$ Ibid., 114.
} 
The effect he experiences upon taking LSD is deep and profound. The first stage is, as Des Tramacchi says, a "visionary landscape." 38 That is how Pelevin depicts Tatarsky's first LSD experience:

"This idea about the sun and the puddle filled Tatarsky with such a feeling of happiness that he laughed out loud in his joy and gratitude. All the problems of life, all those things that had seemed so unsolvable and terrifying, simply ceased to exist for an instant the world was transformed." 39

The happiness is then replaced by fear - how can one live with this type of knowledge, and how can one explain to others what he has just understood? Then Tatarsky realises that actually there is nothing to explain. Everything loses its significance when coming back to the world of reality, that of the words and the concepts. As the Sirruf, a doglike dragon with wings, also depicted as a guardian of the Tower of Babel, who Tatarsky sees in his hallucination, says, "Any insight of true breadth and profundity will inevitably be reduced to words. And the words will inevitably be reduced to themselves." 40

The second stage, as it was already said, is the encountering of certain beings in that visionary landscape. Des Tramacchi provides such a description of this stage:

"Two aspects of entheogenic experience are quite distinctively shamanistic in character. Firstly, entheogenic narratives frequently speak of entering a visionary landscape. Secondly, this landscape is often inhabited by spirit beings that may interact with the psychonaut. In the entheogenic worldview, as in many shamanistic worldviews, these interactions are highly significant and may form the principal object of the 'trip' or 'journey'. The metaphor of the shamanic journey or 'trip' to another world is widely applied to the effects of entheogens.",41

\footnotetext{
38 "The continuities with psychedelic experiences are quite strong, in particular the experience of the dissolution of the ego; however this experience is not necessarily the object of entheogenic practice as it is for some forms of psychedelic practice that aim at nirvana or "non-dual', 'not-I' modes of awareness." (Des Tramacchi, "Entheogens, Elves and Other Entities: Encountering the Spirits of Shamanic Plants and Substances," in Popular Spiritualities: The Politics of Contemporary Enchantment, ed. Lynne Hume and Kathleen McPhillips (Aldershot, England; Burlington, VT: Ashgate, 2006), 93.)

${ }^{39}$ Pelevin, Homo Zapiens, 114.

${ }^{40}$ Ibid., 115. Note that in one interview Pelevin presents a contradictory statement: "Words can never be reduced to themselves because they simply don't have anything that could be called a self. They only come into relative existence as objects of your mind and their meaning and emotional charge may vary significantly from one person to another. What exactly can they be reduced to? Words are the only way to deal with the mind, as mind is also a word and you can only tackle one word with another. However, it doesn't mean that there's nothing beyond words. But it is beyond words only when we are silent about it from the very beginning." (Leo Kropywiansky, interview with Victor Pelevin, http://bombsite.com/issues/79/articles/2481 (accessed April 22, 2011.)

${ }^{41}$ Des Tramacchi, "Entheogens, Elves and Other Entities," 93.
} 
Thus by taking psychedelics, Volodin, Shurik, and Kolyan experience a trip to that 'shamanic underworld' depicted by Pelevin as the mythic Valhalla. By taking LSD, Tatarsky also experiences being in another world where he engages into a conversation with the Sirruff. The Sirruff then tells Tatarsky that he should not take LSD:

"When you take an overdose of LSD or dine on panther fly-agarics, you're stepping away out of line - and you're taking a grave risk. If you only realised how many invisible eyes are watching you at that moment you would never do it; and if you were to see even just a few of those who are watching you, you'd die of fright. By this act you declare that being human is not enough for you and you want to become someone else. But in the first place, in order to cease being human, you have to die." ${ }^{, 2}$

The Sirruff also claims that what Tatarsky has taken is not one of Dutch toys: "it's a numbered issue, an official service document, by eating which you shift across into a different realm where there are absolutely no idle pleasures or amusements." 43

The reason why Tatarsky tried LDS appears to be simple. He confesses to the Sirruff that he just wanted to feel "the pulse of life." 44 This can be interpreted as a desire to feel the state of oneness, non-duality, the need to find the meaning and purpose of life, and to experience the cosmic consciousness. Moreover, Tatarsky later thanks Gireiev for allowing him "to live the parallel life." 45 This again signifies the need for a chance to live another, different life, to escape this reality.

In their quasi-philosophical dialogue about the nature of the Tower of Babel and the human identity, the Sirruff raises one of the most important points:

"You have no idea of what to do with your lives anyway; and whichever way you might turn your eyes, you are still gazing into the flames in which your life is consumed. There is mercy in the fact that in place of crematoria you have televisions and supermarkets; but the truth is that their function is the same. And in any case, the fire is merely a metaphor. You saw it because you ate a pass to the garbage incineration plant. All most people see in front of them is a television screen ..."46

\footnotetext{
${ }^{42}$ Pelevin, Homo Zapiens, 117.

43 Ibid.

${ }^{44}$ Ibid. The Sirruff then lets Tatarsky to feel that pulse, which happens to be his worst life experience.

45 Ibid., 226. Actually, Tatarsky here simply repeats the words that Berezovsky wrote on the note in the envelope with money: "Thanks a lot for sometimes allowing me to live a parallel life. Without that the real one would be so disgusting!" (Ibid., 204-205.) Hence Pelevin once more plays with two different realities and leaves an open question as of whether both these realities are equally 'true'.

${ }^{46}$ Ibid., 120.
} 
Hence Tatarsky's LSD trip enables him to see how people are ready to give up their own mind and free will and to become controlled by media and consumerism. This trip also serves as his preparatory stage for becoming the monetary god who controls all the media and dictates people's beliefs.

Throughout all the literature concerning psychedelics it is often claimed that the psychic state of the person who takes drugs is crucially important. Typically only with the right attitude and being in the right environment can a person experience the true enlightening impact of the substances. If people take psychedelics irresponsibly, trying to escape from their repressed emotions, they might experience a so-called bad trip, usually characterised by a panic attack. ${ }^{47}$ What they face during their psychedelic experience are actually those repressed parts of their personality or shadows. This is how Mike Young describes the bad trip:

\begin{abstract}
"In the old days, the bad acid trips were frequently as much from the lack of religious preparation as anything else. When users found themselves with their egos dying, they panicked. Nobody had ever told them that the dark night of the soul is a normal experience for those who stand naked before the universe and themselves. Nobody had told them that they were going to experience being one with the universe. Not just thing they were, or come to believe it, kind of. Rather, they were going to experience, in the corpuscles of their beings, that there is no boundary between where 'I' stops and the universe begins. That can scare you to death!"48
\end{abstract}

Thus what for mystics is an ultimate aim - breaking down the boundaries of the ego and experiencing the oneness with the universe - can become for the unprepared person their worst nightmare as in Tatarsky's case. Frightened to death by his experiences in the acid world, he asks Gireiev for help. The latter suggests that Tatarsky should recite a mantra, which ironically appears to be a simple sentence from the Hebrew textbook. When neither the mantra nor vodka helps, he even turns to god asking for help. He kneels down saying his invented prayer:

\footnotetext{
47 "A simplified description of the action of the sacrament is that it dissolves the barrier to the unconscious mind, making the unconscious contents available. This can reveal buried painful memories and repressed feelings, values, and drives as described by Freud, which parallel the human archetypes and collective unconscious postulated by Carl Jung. Beyond these descriptions, vast ranges of mind become evident, including esoteric concepts of universal mind, remarkable floods of imagery, and an overflowing source of fresh thoughts, intuition, and creative ideas. Ultimately one can find at the heart of being an awesome source of light, energy, beauty, meaning, and unsurpassed love that is the very revelation of Divinity." (Myron Stolaroff, "A Protocol for a Sacramental Service," in Psychoactive Sacramentals: Essays on Entheogens and Religion, ed. Thomas B. Roberts (San Francisco: Council on Spiritual Practices, 2001), 156.)

${ }^{48}$ Mike Young, "If I Could Change Your Mind," in Psychoactive Sacramentals: Essays on Entheogens and Religion, ed. Thomas B. Roberts (San Francisco: Council on Spiritual Practices, 2001), 7.
} 
"I'll never eat any of that junk again. I ... I only want to be happy, and I just can't manage it. Perhaps it's what I deserve. I can't do anything else except write bad slogans. But for Thee, oh Lord, I'll write a good one - honest I will. You know, they do position Thee quite wrongly. They haven't got a clue., 49

Note the confession "I only want to be happy" in Tatarsky's improvised prayer. The search for happiness remains the core need for people and can be perceived as the core of what is sacred for them. However, the definition of that happiness remains blurred and unclear. Tatarsky searches for happiness in the altered state of mind induced by psychedelics, and this search perfectly reflects the epoch of general confusion, liminality and mixed values.

Another popular argument for the use of psychedelic substances is a widely held opinion that after psychedelic encounters, people experience a change in their attitude and behaviour, and can further enhance their spiritual search. ${ }^{50}$ However, Tatarsky did not experience any kind of spiritual change after his LSD experience. His newly found ironic pseudo-religious devotion had vanished by the next day. But it can be argued too that this LSD experience enhanced a different type of change - one that allowed Tatarsky to enter the world of the monetary sacred. Thus this experience might be regarded as an initiation into the monetary world or the secret Chaldean guild. After his psychedelic adventures he eventually gets promoted and finally becomes the monetary god, the ritual husband of the Goddess Ishtar. Hence Tatarsky's LSD trip can be seen as a journey to this highest position.

As was noted, Pyotr in Buddha's Little Finger did not have to use any mind-altering substances in order to enter Valhalla (the world of those who were warriors during their lifetime), because he lived in-between the two different worlds and he could enter that underworld with the help of Baron Jungern. However, as depicted in the episode by the fireplace, Volodin, Shurik and Kolyan had to take psychedelic mushrooms in order to enter other realms. After the prolonged philosophical debates they finally experienced the effect of the psychedelics and 'travelled' into another sphere: “... and suddenly they were surrounded by this light, and there was nothing else around them at all. ... In reality, there weren't any sides at all, or any voices either. Instead of the voice there was a certain presence, which announced itself in a way that made it clear it was Shurik." ${ }^{\text {" } 1 ~}$ In that world, according to

\footnotetext{
${ }^{49}$ Pelevin, Homo Zapiens, 123.

${ }^{50}$ As in already mentioned Pahnke's Good Friday experiment. (Paula Jo Hruby, "Unitive Consciousness and Pahnke's Good Friday Experiment," in Psychoactive Sacramentals: Essays on Entheogens and Religion, ed. Thomas B. Roberts (San Francisco: Council on Spiritual Practices, 2001), 58-68.)

${ }^{51}$ Pelevin, Buddha's Little Finger, 263.
} 
Shurik, there is nothing to be frightened of. "I know everything. I can see everything. I can see and understand anythin' you like." 52 However, they were quickly spotted by Baron Jungern and attempted to escape. This is the moment when Pyotr's two realities collide: he encounters people from his other reality, the dream world, in the realm of the mysterious underworld.

In Pelevin's fictional world psychedelics enter a person into another world, although it is perceived as a wrong way, as entering that other world through the back doors. As Baron Jungern says, those attempting to get to this realm are just "petty hooligans high on shamanic mushrooms." 53 Here, Pelevin questions the same problem as the scientists and curious spiritual seekers did in the 1960s and 1970s, namely, whether the experience with psychedelics can actually be equal to any other sort of a non-chemically induced spiritual experience. Or, as David Steindl-Rast asks, "If we can encounter God through a sunrise seen from a mountaintop, why not through a mushroom prayerfully ingested? But precisely because an overpowering encounter with God through an entheogen can happen to one who is quite unprepared for it, we must ask: Can this be genuine?"54 $\mathrm{He}$ also gives an answer to that question: "A primary religious experience is no more (though also no less) than a seed for a spiritual life." $" 55$ Thus the recreational use of psychedelics here is distinguished from the use born out of the spiritual search. However, although LSD and other psychedelic substances do not enhance Tatarsky's spiritual world, they do play an important role in his journey towards his role as a monetary god in the contemporary consumer society.

\subsection{Drug of Boredom and Suffering}

Another drug, the use of which is depicted in Pelevin's novels, is cocaine. It can be briefly defined as a stimulant of the central nervous system, which also has anaesthetic qualities. Its use is depicted in the novels Buddha's Little Finger and Generation P. In the latter, cocaine is associated with Tatarsky's days in the advertising industry and his work (he uses it at work in the toilet, sniffing a line through a rolled-up hundred-rouble bill). ${ }^{56}$ Hence it

\footnotetext{
52 Ibid.

${ }^{53}$ Ibid., 222.

54 David Steindl-Rast, "Psychoactive Sacramental: Foreword," in Psychoactive Sacramentals: Essays on Entheogens and Religion, ed. Thomas B. Roberts (San Francisco: Council on Spiritual Practices, 2001), XII.

${ }^{55}$ Ibid.

${ }^{56}$ Pelevin, Homo Zapiens, 53.
} 
has very close associations with money and the monetary sacred. Moreover, cocaine itself, as he notices, is packed into the glossy magazine advertisement for Toyota Camry, and "Tatarsky was tormented by the unbearable suspicion that they made a fat living not just at the expense of other people's health, but by providing a PR service as well., 57

This is how he sees his own addiction to cocaine:

"Every time Tatarsky asked himself why he and others paid all that money in order to subject themselves once again to a humiliating and unhygienic procedure, the only explanation he could come up with went as follows: people weren't sniffing cocaine, they were sniffing money, and the rolled-up hundred-dollar bill required by the unwritten order of ritual was actually more important than the powder itself." 58

Thus what forces him to snort cocaine is actually its symbolism of monetary power. Cocaine both gives the power and shows the monetary power of the person using it. It is rather a matter of one's status, so Tatarsky also uses it although he hates that the cocaine available is hardly pure. Snorting it is also regarded as a trademark of a copywriter and can be seen as a sort of 'show-off' or, to put it other way, a banal must-do in the advertising industry. Cocaine serves as a means to stay grounded as well, to remain in touch with the reality of the monetary, consumer society, and the advertising business: "Then, when the work comes piling in, and you do a line of coke, you'll spend the whole day on the run fencing concrete problems. You won't have time left for the abstract ones."

Tatarsky's cocaine abuse signifies his social status rather than the addiction itself. The presence of a $\$ 100$ bill in the ritual of sniffing cocaine explicitly shows the essence of the use of cocaine: its material value and the status it gives, but not the effect it grants.

Moreover, it can be argued that cocaine serves as an anaesthetic not only in the literal but also in the metaphorical sense of this word - it helps to become less sensitive to the outside world. For example, Pyotr in Buddha's Little Finger snorts cocaine straight after murdering his friend because he needs "to recover control rapidly."60

Audun J. Mørch argues that the pharmacological properties of cocaine make it correspond to both the energy and brutality associated with Bolshevik commissars. ${ }^{61}$ In addition, the same energy and brutality can be associated with the businessmen and advertising gurus at the end of the $20^{\text {th }}$ century. The latter also aim to establish their truths

\footnotetext{
${ }^{57}$ Ibid.

${ }^{58}$ Ibid., 54.

${ }^{59}$ Ibid., 176.

${ }^{60}$ Pelevin, Buddha's Little Finger, 11.

${ }^{61}$ Mørch, "Reality as Myth," 76.
} 
and ideology, though by using different means than the Bolshevik commissars. Mørch also notes the role of the opium, which is occasionally used in Buddha's Little Finger as reflecting the state of people using it:

"Likewise, in a literary café whose clientele is dominated by decadent poets (although members of the Cheka are also present), Petr Pustota notices that someone is smoking opium. Considering its context, opium is given a mythic sign value similar to that of the Nagant revolver, and the well known pharmacological properties of opiates correspond: a class of people that has become inadequate has no need for a stimulant like cocaine. Their preferred drug is one that obliterates their pain and sense of being displaced." 62

Cocaine is depicted as merely the embodiment of monetary force and brutal power. Even a more extreme example is the Baltic tea - cocaine mixed with vodka - that Pyotr drinks with Zherbunov and Barbolin. After being released from psychiatric hospital, he finally returns to the same cafe and orders a drink tailored for the end of the $20^{\text {th }}$ century vodka with Ecstasy. However, the latter serves as a means of enhancing one's status and fails to become an important means to search for the sacred. This drink reflects the in-betweenness of the epoch as vodka can be considered more of a symbol of the (pre)Soviet time, whereas Ecstasy is of the post-Soviet time.

However, even though in the post-Soviet years drugs rapidly started to replace alcohol, vodka did not cease to exist, and its importance is still obvious. The next section will explore the use of alcohol and its relation to the sacred and nostalgia.

\subsection{A Moment of Blissfulness}

"If we put it your way, the most compelling Western philosophers in my life were Remy Martin and Jack Daniels. They compelled me to do many things I otherwise would never think of."63

According to Victor Pelevin, there are two ways a post-Soviet person can deal with the feeling of depression. Tatarsky in Generation $P$ describes it as "down a hundred grams of vodka, or spend about a hundred dollars on buying something." 64

\footnotetext{
${ }^{62}$ Ibid., 76-77.

${ }^{63}$ Leo Kropywiansky, interview with Victor Pelevin, http://bombsite.com/issues/79/articles/2481 (accessed April 18, 2011).
} 
The use (and abuse) of alcohol holds an important position in Russia's social and cultural history. By controlling the alcohol market, Russian authorities always used it as a means "to command obedience and loyalty as well as to make as much profit as possible.",65 During the $16^{\text {th }}$ and $17^{\text {th }}$ centuries the state harshly protected its monopoly on alcohol production and sale. As a German traveller recalls, "The pothouses, saloons, and taverns, or kruzhechnyje dvory as they are now called, bring the Grand Prince - who now owns all of them through the country - an extraordinary amount of money, since the Russians know no restraint in drinking vodka." 66 People would come to the so-called kabaks and leave them completely drunk, with empty wallets or would even leave their clothes there for yet another drink and go home naked. Russian writer Fyodor Dostoevsky depicts the following scene, which illustrates the relationship between the church and the tavern:

"A fire broke out in the village and spread to the church. Presently, the innkeeper appeared on the scene and cried out to the people that if they would cease putting out the fire in the church but would save his pot-house, he would give them a barrel of liquor. The church burned down, but the pot-house was saved."67

During the Soviet period, due to the restrictions and a need for privacy, the consumption of alcohol took place in the private homes and communal kitchens. Alcohol helped to bond, to create those communitas united by the same pain, unfulfilled desires, fear, and hatred for the system. Alcohol abuse was always a means to escape the harsh reality and to relieve the pain. It also marked all the important dates of people's life, such as births, christenings, marriages, becoming an inseparable part of their rites of passage: "Even losses and grief, chagrin and sorrow needed to be smoothed away through companionate drinking. ${ }^{68}$ In the post-Soviet state, alcohol abuse helped to escape the heavy burden of responsibility that came with the break-up of the Soviet Union.

Therefore, vodka has always held a significant position in Russian mentality, history and culture. It is also a significant a part of Tatarsky's life as a prospering copywriter. Vodka participates in the quasi-philosophical conversations between Chapayev and Pyotr as an important element of the philosophical discoveries. One of the most illustrative examples for the use and effect of alcohol can be found in the novel's Buddha's Little Finger episode with

\footnotetext{
${ }^{64}$ Pelevin, Homo Zapiens, 69.

${ }^{65}$ Patricia Herlihy, "Revenue and Revelry on Tap: The Russian Tavern," in Alcohol: A Social and Cultural History, ed. Mack P. Holt (Oxford, New York: Berg, 2006), 197.

${ }^{66}$ Ibid., 187.

${ }^{67}$ Ibid., 194.

${ }^{68}$ Ibid., 197.
} 
Serdyuk, one of the patients from Pyotr's psychiatric clinic. Pelevin, comprehensively, almost poetically describes the emergence of an idea to have something to drink:

"It's not really possible to say what exactly went on in his head over the next few minutes, but when the train stopped at Pushkinskaya station and Serdyuk emerged from the carriage his own soul had become filled with the fixed desire to have a drink - in fact, to take an entire skinful of something. Initially this desire remained formless and unrecognized, acknowledged merely as a vague melancholy relating to something unattainable and seemingly lost forever, and it only assumed its true form when Serdyuk found himself face to face with a long rank of armour-plated kiosks, from inside which identical pairs of Caucasian eyes surveyed enemy territory through narrow observation slits." 69

Alcohol craving here is depicted as a desire for something unattainable and lost. Moreover, as it can be seen further, it can bring out important memories. After spending a significant amount of time choosing the bottle (as it is definitely a very important choice), Serdyuk finally spots one of 'Livadia' wine. The bottle of port wine that he chooses reminds him of a "forgotten morning in his youth", together with a group of students handing round the same bottle of wine. However, it is not only the memory of the happy days that influences his choice:

"But the most important thing in all of this wasn't the port wine or the railings; it was the fleeting reminiscence that triggered a pang of sadness in his heart - the memory of all the limitless opportunities and endless highways there used to be in the world that stretched away from that corner of the yard." 70

It is the painful longing for the past that could not be reached anymore. Moreover, this past not only exists no more, but might never have existed, as it is the longing for "limitless opportunities" and "endless highways", that is, for the hopes of the better future that had never come true. As Serdyuk painfully realises, it is not the world that has changed, but he himself - "that little patch of emptiness behind the railings had long since been completely paved over with zinc-plated coffins of experience." ${ }^{71}$ Painful longing for the past can also be named as a longing for the state of innocence, when one's soul was tabula rasa yet to be filled with words, feelings, experience and memories. The "little patch of emptiness" here carries on a different meaning than the emptiness in Chapayev's and Pyotr's conversations, or the emptiness that will be discussed in the seventh chapter - it is a hopeful emptiness, one

\footnotetext{
${ }^{69}$ Pelevin, Buddha's Little Finger, 153.

${ }^{70}$ Ibid., 153-154.

${ }^{71}$ Ibid., 154.
} 
bearing a promise to be meaningfully filled. It is the emptiness of a young soul having no fear of limits as there were no existing limits; they are created later on and exist only in one's head. Nostalgia for the past emerges as nostalgia for the lost sacred. It is both a sense of something lost forever and at the same time a sense of the endless possibility. Nostalgia here presents itself as the only one emotional connection to the things and beliefs that were once sacred. It is nostalgia for the stability, clarity and the age of innocence.

Svetlana Boym defines nostalgia (from nostos - return home, and algia - longing) as "a longing for a home that no longer exists or has never existed." 72 In her book she presents the history of this feeling and the change of its perception: from the notion that nostalgia is a curable disease, to the incurable modern state. She writes that nostalgia is "a sentiment of loss and displacement, but it is also a romance with one's own fantasy.,"73 But even more important is her understanding of nostalgia as being not only the longing for a place, but also for a different time - "the time of our childhood, the slower rhythms of our dreams."74 Nostalgia does not necessarily have to be connected with the past - it can be both retrospective and prospective, both for the past and the future. Nostalgia can be a longing for a place, time or object that cannot be defined, that remains beyond the words and descriptions. This feeling is a repeating motif in Pelevin's novels, although not always put explicitly, shining through the postmodern irony, present in the liminal state of a person. It is nostalgia for the things sacred that no longer exist or, once again citing Svetlana Boym, may have never existed.

However, as Serdyuk realises later, "if he couldn't view the world through those same eyes any more, he could at least try for a glimpse of it through the same glass, darkly.,"75 Hence alcohol becomes a means to once again experience the world that is lost; to enter that in-between state, when one's physical body is still in this realm, while the intoxicated mind searches for the lost space and time. The consumption of alcohol in this case provides us with a classical example of an escape from the current reality that has become unbearable.

The role that alcohol plays by bringing out the memories reminds us of an episode from Marcel Proust's novel in the seven volumes In Search of Lost Time. In this famous episode the taste of a madeleine dipped in tea reminds the protagonist of a childhood scene

\footnotetext{
${ }^{72}$ Svetlana Boym, The Future of Nostalgia (New York: Basic Books, 2001), XIII.

${ }^{73}$ Ibid.

${ }^{74}$ Ibid., XV.

${ }^{75}$ Pelevin, Buddha's Little Finger, 154.
} 
long forgotten, and brings back dear memories. ${ }^{76}$ For Serdyuk, it is not only a moment of his youth. It is also a memory of his childhood, lost innocence, which here for him takes the role of the sacred.

The effect of alcoholic intoxication is a moment of blissfulness: "The intoxication mounted to its blissful zenith, lingered for a few brief seconds at the highest point, and then the usual ballast of drunken thoughts dragged him back down into reality." 77 It is an attempt: to reach the blissful state of unity with the universe, the freedom of ego and the alienated self; to experience the sense of non-duality, and at the same time, a state of blissful helplessness, irrationality and irresponsibility; and to return to childhood and innocence. Hence alcohol serves as a means to reach out to the long-forgotten memories of youth and the time when everything was seemingly so clear, simple and innocent. It is not the world of words and concepts, but the world of emotions and images.

However, seduced by nostalgia and trapped in it, people do not attempt to move forward and to create the new forms of the sacred (identity, meaning, and truth) in their daily lives. Instead, they linger in the past, where, as they suppose, the basis of all things sacred lost forever lays. This nostalgic yearning for the experience of the sacred and inability to regain it perfectly reflects the confused state of the liminal post-Soviet person as depicted by Pelevin.

\footnotetext{
76 "And suddenly the memory returns. The taste was that of the little crumb of madeleine which on Sunday mornings at Combray (because on those mornings I did not go out before church-time), when I went to say good day to her in her bedroom, my aunt Léonie used to give me, dipping it first in her own cup of real or of limeflower tea. The sight of the little madeleine had recalled nothing to my mind before I tasted it; perhaps because I had so often seen such things in the interval, without tasting them, on the trays in pastry-cooks' windows, that their image had dissociated itself from those Combray days to take its place among others more recent; perhaps because of those memories, so long abandoned and put out of things, including that of the little scallop-shell of pastry, so richly sensual under its severe, religious folds, were either obliterated or had been so long dormant as to have lost the power of expansion which would have allowed them to resume their place in my consciousness. But when from a long-distant past nothing subsists, after the people are dead, after the things are broken and scattered, still, alone, more fragile, but with more vitality, more unsubstantial, more persistent, more faithful, the smell and taste of things remain poised a long time, like souls, ready to remind us, waiting and hoping for their moment, amid the ruins of all the rest; and bear unfaltering, in the tiny and almost impalpable drop of their essence, the vast structure of recollection." (Marcel Proust, Swann's Way, trans. by C.K. Scott Moncrieff (London: Chatto \& Windus, 1957), 62.)

${ }^{77}$ Pelevin, Buddha's Little Finger, 155.
} 


\subsection{TV as an Ultimate Escape}

"TV and the Internet are good because they keep stupid people from spending too much time out in public," notes ironically Douglas Coupland. ${ }^{78}$ In the novel Generation $P$ the tension between the 'real' world and reality as mediated by TV becomes evident. It becomes a seemingly safe and relatively cheap possibility to escape into the dream world without the use of any conscious efforts or responsibility, as the only action that a person is to undertake is just switching from one TV channel to another. It could as well be understood as less dangerous than drugs or alcohol. ${ }^{79}$

This escape, however, might be regarded as ambiguous: both conscious and unconscious. On the one hand, Tatarsky has voluntarily chosen his career as a copywriter and, later, as a creator of TV programmes. ${ }^{80}$ On the other hand, although his escape into the other side of the TV screen is in a sense a conscious action, millions of people every day unconsciously escape into the seductive images of TV-programmed reality.

Pelevin explicitly shows the mechanism of this escape. This is how Che Guevara, speaking out of an Ouija board, describes the process of watching TV:

"What is taking place could appropriately be called the experience of collective nonexistence, since the virtual subject that replaces the viewer's actual consciousness is absolutely non-existent - it is merely an effect created by the collective efforts of editors, cameramen and producers." 81

According to him, the subject watching TV totally disappears from his own reality and immerses in reality produced by TV. It is the absolute escape, an abandonment of one's consciousness or, as Pelevin puts it, the collective non-existence: "Subject number one believes that reality is the material world. But subject number two believes that reality is the material world as it is shown on the television." 82 Pelevin also draws a pessimistic comparison of the state of a modern person:

\footnotetext{
${ }^{78}$ Douglas Coupland, JPod (New York: Bloomsbury, 2006), 7.

79 At least two aspects that allow comparing drugs, alcohol and watching TV are a need to escape and a possibility of the evolving dependency.

${ }^{80}$ However, Tatarsky became a media god and a husband of the goddess involuntary - he was perceived as 'the chosen one'.

${ }^{81}$ Pelevin, Homo Zapiens, 80.

${ }^{82}$ Ibid., 81.
} 
"The position of modern man is not merely lamentable; one might even say there is no condition, because man hardly exists. ... [I]t is a film about the shooting of another film, shown on a television in an empty house." ${ }^{83}$

A person, who is constantly switching TV channels to avoid watching the advertisements (zapping) is named Homo zapiens. ${ }^{84}$ Thus he is no longer Homo sapiens, thinking man (neither is he Homo sovieticus anymore), but someone who is programmed by the images on TV. This escape results in the blissfulness of non-thinking, a sort of a modern state of non-duality (when a human and TV becomes one). This artificially constructed TV world, as Pelevin shows in Generation $P$, is false from the very beginning, as seemingly real people on TV screens are just digitally programmed dummies. Yet, paradoxically, this escape provides people with the sense of identity, meaning, and community. It has the power to form the new (monetary) sacred. The identity is formed according to what is dictated on TV ads; the community is created out of those whom Pelevin names Homo zapiens. As Pelevin puts it, a person himself becomes a TV programme: "It is a television programme watching another television programme., ${ }^{, 85}$

Pelevin also repeats a well-known truth that what are advertised are not simply goods but plain human happiness:

"Because it's never the things that are advertised, it's human happiness. The people they show are always equally happy, only the happiness comes from buying different things in different cases. So people don't go to a shop to buy things, they go there looking for this happiness; but the shops don't sell it." 86

It is happiness that Tatarsky searches for in his LSD experiences, ${ }^{87}$ and it is happiness that people search for while zapping TV channels. Consumer society attracts people with the endless promises of shortcuts to paradise. On the other hand, Gireev, who in this novel plays an outcast, a rebel in consumer society, offers an ironic Buddhist alternative to watching TV, which is, watching it upside down and not giving up to the seductive images produced by it. ${ }^{88}$

As noted, in the search for an alternative reality and in the need to escape from the present one, Tatarsky toys with various drugs and finally ends up becoming one of the illusory images multiplied in TV screens. After his initiation into the position of the Goddess

\footnotetext{
83 Ibid., 82.

${ }^{84}$ Homo Zapiens is also a title of the novel Generation $P$ for the US audience.

${ }^{85}$ Pelevin, Homo Zapiens, 81.

${ }^{86}$ Ibid., 127.

${ }^{87}$ Ibid., 123.

${ }^{88}$ For Gireev's depicted Buddhist ways of watching TV see ibid., 221-222.
} 
Ishtar's ritual husband and media corporation head, thousands of his images flood TV screens. It would seem that Tatarsky reaches the final and most desirable step of his career that would provide him with a sense of meaning and identity. However, in the last sentences of Generation P, Pelevin leaves the reader slightly in doubt. The unfinished TV clip for the Tuborg beer is Tatarsky's most favourite role on TV and can be regarded as an ultimate escape, or at least a dream of an ultimate escape:

"Tatarsky, wearing a white shirt open at the chest, is walking along a dusty track under a sun standing at its zenith. Suddenly he is struck by some kind of thought. He halts, leans against a wooden fence and wipes the sweat from his face with a handkerchief. A few seconds go by, and the hero seems to grow calmer. Turning his back to the camera, he stuffs the handkerchief into his pocket and slowly walks on towards the bright-blue horizon, where a few wispy clouds hang high in the sky." 89

Tatarsky's escape into the TV world eventually led him to the position of 'the media god' in consumer society. He connects with the world through the safe distance of the TV screen, and creates and manipulates the reality of people. Such an ending can be regarded as pessimistic if looking at it from the position of the 'traditional sacred' and traditional value systems. However, I would regard it as Pelevin's attempt to reflect the current state of postSoviet people searching for the substitutes for lost universal and eternal values.

This escape can also be interpreted two ways: after escaping into TV reality, Tatarsky attempts to get out of there and thus is filmed in a symbolic exit scene, realising that there is no way back after being trapped in the artificial TV world. This ultimate escape remains only an unattainable desire, reflected in the clip, which was never shown to the public (and which brings tears to Tatarsky's eyes). This can be seen as mourning for his previous state of the search, and of the unlimited possibilities of the liminal state. Escaping into the world of advertising, TV and power, Tatarsky ultimately finds himself defined, limited and imprisoned.

A version of the clip depicting 30 Tatarskys walking along the road one after the other is also a Pelevin's subtle hint that a person should search for the truth inside and not outside. ${ }^{90}$ The sacred can present itself as external as well as internal category.

\footnotetext{
${ }^{89}$ Ibid., 250.

${ }^{90}$ The image of thirty Tatarskys reminds us of the story which Tatarsky heard while being high on fly-agarics. It is a story about 30 birds which flew off to search for the bird called Semurg, the king of all birds and the source of all great knowledge. Finally they found out that the word 'Semurg' means '30 birds'. (Pelevin, Homo Zapiens, 35.)
} 
In the essay entitled The Temporary Autonomous Zone American writer Hakim Bey notes that the "negative side", the anti-gesture of refusing the church is, unsurprisingly, watching TV. ${ }^{91}$ This statement holds true in the sense that both the church and TV carry on the same significance for people. The importance of TV should not be dismissed as if it were only a recreational activity. In the postmodern or, in this case, the post-Soviet state, TV takes on the role of forming identity, meaning and community for people, and has close associations with the so-called 'monetary sacred' of consumer society.

\subsection{Conclusions}

This chapter disclosed the notion of escape and its various modalities in Pelevin's prose. It argued that this notion can be attributed to the non-conventional manifestations of the sacred, and explored how psychedelics, alcohol, and immersion in TV-mediated reality form and shape the concept of the sacred. Recreational use of psychedelics here was not dismissed as it can equally reflect what is sacred.

This escape itself can in a sense be understood as sacred: an overwhelming desire to escape the surrounding reality that is no longer satisfactory, or to connect with the world that is lost. Hence psychedelics can be the most illustrative metaphor and the most visible means of that escape, which can present itself in other forms such as art, ideology, or religion.

And herein is the paradox. Traditionally, the escape world would be perceived as the anti-structure, as opposed to the structured world of the consensus reality. However, Pelevin's protagonists are trying to escape from the liminal, disorganised reality, where remains of the traditional structure/sacred could hardly be found. Thus the protagonists attempt to escape out of this liminal sphere, in order to search for new 'sacreds' in their changing lives. Escape is meant to provide new meanings and a new sacred (structures). It is not only an escape from, but also an escape 'to': a trip in search for the new sacred (experiences) and, possibly, a search for the "shortcuts to paradise", the use of psychedelics being an illustrative example.

For some protagonists, this striving for escape can become a permanent need and the safest option in their liminal world. Pelevin clearly shows this in his example of escape in

\footnotetext{
91 Hakim Bey, “The Temporary Autonomous Zone,” http://hermetic.com/bey/taz3.html\#labelTAZ (accessed May 26, 2011).
} 
TV-mediated reality. At this point, the escape world becomes routinised. This example emphasises doubt, which lies at the core of Pelevin's works, namely, whether any escape can be or is meaningful. ${ }^{92}$

Ironically, in the case of the alcoholic intoxication Pelevin shows that the outcome of this attempt to escape is merely a return to the 'old sacred' - nostalgia for the Soviet past. In a sense, all these modes of escape block the evolution of the protagonists. They either dwell in the past, or transfer themselves into the TV reality, or into the alternative reality induced by psychedelics. Although the protagonists are generally not satisfied with their current state, they do not strive to move forward. They obey the newly found teachers (Pyotr), or obediently follow their predicted destiny (Tatarsky). This fatalistic attitude generally coincides with the nostalgic, indecisive state of post-Soviet people portrayed by Pelevin.

The notion of nostalgia needs to be further evolved. In Pelevin's fragmented postSoviet world people attempt to return to the lost state of innocence (childhood), stability, universal knowledge and endless possibilities by various means, including alcoholic intoxication. Nostalgia in this case can also be regarded as an attempt to regain the lost sense of identity, meaning, truth, and the sense of belonging to the community, and therefore is closely intertwined with what is regarded as the sacred. However, as it was mentioned, contemporary transcendence as depicted by Pelevin can be found only in TV images or through nostalgia for the past. This Pelevin's-depicted-nostalgia can be interpreted using Boym's definition: as longing for the objects, times and spaces that exist no more or might have never existed. This nostalgic yearning for the lost sacred - the lost structured life and inability to regain it - once again reflects the confused state of the post-Soviet people.

The search for happiness remains the core need of people and thus the sacred. However, this notion is hard to define in the times of general disorder and mixed values. It is hard to imagine that one universal truth and reality could be valid for Pelevin's post-Soviet people who are no longer capable of believing in the universal values. As the Soviet eternity and universal values ceased to exist, the only possible belief system left for Tatarsky is that associated with the monetary sacred. That said, although LSD and other psychedelic

\footnotetext{
${ }^{92}$ Interestingly, despite the rumours that Pelevin is a drug dealer, in various interviews he unambiguously expressed his negative attitude towards any mind-altering substances. As he once put it, "I do not smoke, do not drink and I think that we should not interfere directly in the chemistry of the brain, at least not on a continuous basis, it leads only to the dependency on the chemicals and does not solve any human problem. Drugs in general can solve only the problems that they themselves have created beforehand. And then, what does it mean, 'The expansion of the consciousness?' Consciousness does not have such features as length or width, it does not need to be expanded or deepened. I think it constantly needs to be cleansed, and for this task drugs are not only useless, they are harmful. The human body is capable to produce any necessary chemistry." (Vladimir Vorobjev, "Pravila zhizni Viktora Pelevina," http://esquire.ru/wil/pelevin (accessed August 8, 2012.)
} 
substances do not enhance Tatarsky's spiritual evolvement, they do play an important role in his journey towards his role as the monetary god in contemporary consumer society. Money and power are clearly modelled as sacred in consumer society, channelled through seductive advertising images. TV undoubtedly takes on the role of forming identity, meaning and community for people, and is closely intertwined with the monetary sacred of consumer society. The use of cocaine also serves as an embodiment of monetary force and brutal power, showing an ability to establish one's power and control over life.

The next chapter explores the ultimate escape, that is, the search for freedom, and discusses whether such absolute freedom, or final liberation, can be possible in Pelevin's world. 


\section{Chapter 7:}

\section{The Sacred Journey to 'Freedom'}

"A good traveller has no fixed plans, and is not intent on arriving." Lao Tzu

The previous chapter discussed the various modes of escape as depicted in Victor Pelevin's texts. It established that the search for alternative forms of the sacred can take the forms of escape, namely, through drugs, alcohol, or immersion in TV reality. The result of such attempts can be regarded as the escape from the surrounding everyday reality and entering another, unknown world or connecting with a world now lost. This overwhelming desire to escape a reality that is no longer satisfactory can be thus understood as sacred itself.

This chapter discusses the ultimate manifestation of striving for an escape: the search for freedom and liberation. This ultimate freedom can be reached by the transformation of the protagonist, which can be external and/or internal, physical and/or spiritual. Such a process of transformation can be regarded as a certain journey, figurative or real, that the protagonists undergo in order to reach their final destination. This destination can be their transformed personality, a more profound understanding of society in which they are living, their changed position in that society and, in some cases, the total escape from this world - a final liberation.

This journey can also be interpreted as a personal search for what is considered sacred for the protagonists: the search for the objects or the concepts that constitute the highest and most important meanings and truths for these individuals. Because of the constantly repetitive motifs, associations and characters, it can also be argued that each of the books also presents Pelevin's personal questioning of ultimate meaning, his personal searching for the sacred in the life of a contemporary person and analysing whether such concepts can truly exist.

Anthropologist Richard P. Werbner defines a sacred journey as having focused upon a sacred centre: "the sacred centre is a focus of the cosmos, either of the microcosm, which is the exclusive cosmos of particular gods and their creatures, or of the macrocosm, which is the 
inclusive cosmos of the God of everyone, boundless, all-embracing, and complete." ${ }^{\text {He notes }}$ that the link between ritual passage and sacred journey is an integral one. The transformational journey can be depicted as internal and/or external even though the boundaries between the external and internal understanding of this journey are sometimes blurred and unclear. An internal journey can take the form of the rites of passage - some of these cases were already discussed in the fifth chapter. Note, for example: Tatarsky's metamorphosis from a former poet and kiosk salesman to the position of a living god and the husband of the Goddess Ishtar in Generation P; Rama's initiation into the vampire society in Empire $V$; a young dung beetle and his coming of age episode in the short story Initiation, and Omon's final understanding of the absurdity of the Soviet empire and its farce in Omon $R a$. Here, transformation can also be regarded as an expanded awareness. Omon's story can also be an example of both the internal and external journey - the fabricated flight to the moon helps him to realise the absurdity of the Soviet state. Another possible example of the internal journey and transformation is A Hu-Li's ultimate liberation in The Sacred Book of the Werewolf. Only by realising the true nature of life is she able to liberate herself from her earthly body and enter into the Rainbow Stream. Some resemblances to an initiation ceremony can also be seen in her conversation with the Yellow Master, during which he reveals some certain secret knowledge and initiates her into the spiritual path of liberation.

In one of Pelevin's more recent books, $T$, the journey is fully externalised; throughout the entire story Count T. tirelessly searches for a place named Optina Pustyn, the meaning of which is discussed later in this chapter. The external version of this transformational journey also resembles a pilgrimage, which is transformation as well, because after the journey the traveller is no longer the same.

This journey can be described as transformation from immaturity, ignorance, and apprenticeship to maturity, knowledge, mastery, and adulthood. In this regard it reminds us of initiation that was already analysed in the fifth chapter, but this chapter goes one step further. As mentioned, this journey can sometimes be regarded as external, into a physical place (as, for example, Omon's 'flight' to the moon or Count T.'s continuous searching for Optina Pustyn), but even in this case it still carries a symbolic significance. In Pelevin's novels, the apprentice begins his or her journey, which may or may not end in the final liberation and an understanding of ultimate truths.

\footnotetext{
${ }^{1}$ Richard P. Werbner, Ritual Passage, Sacred Journey: The Process and Organization of Religious Movement (Washington: Smithsonian Institution Press; Manchester, UK: Manchester University Press, 1989), 2.
} 
Whatever the final destination or an outcome of the transformation might be, this journey is significant in itself because it helps to reveal what is sacred for the protagonists the objects or concepts that carry the most important meaning and constitute their identity. This journey in Pelevin's books is presented as taking place in a land of twilight, in a liminal state. Having no clear set of values and undergoing transformation, the protagonists attempt to create their own values and meanings, to draw their forms of the sacred out of the postmodern chaos and void. Apprenticeship, journey, pilgrimage, rites of passage, escape, emptiness, liberation and freedom thus constitute the code words for Pelevin's prose.

The following sections provide a more detailed overview of the examples of such journeys and destinations, and a discussion about the sacred that the protagonists attempt to achieve. But most importantly, these sections emphasise the importance of freedom. This concept had already started evolving from the first of Pelevin's works, Omon Ra and The Yellow Arrow. Journeying in the train to an undefined destination, as in Omon Ra, symbolises the ending of life in the Soviet state and entering another, yet unknown, realm. Andrei's escape from the train can symbolise liberation from this worldly reality or the start of the conscious journey in this world. Therefore, this story can also be regarded as a metaphorical tale about the state after the break-up of the Soviet Union, and demonstrates the beginning of what eventually will evolve into Pelevin's searching for the ultimate escape as depicted in his later books. However, there, he also doubts whether absolute freedom is possible to achieve at all, and whether such a notion as an absolute escape can exist. The next sections explore this question.

\subsection{The Path to Liberation}

"I myself wouldn't even attempt to say what love is - probably both love and god can only be defined by apophasis, through those things that they are not. But apophasis would be wrong, too, because they are everything."2

The Sacred Book of the Werewolf, first published in 2005, both repeats the motif of the search for the ultimate liberation and stands out as a curious exception because of the importance and emphasis on the notion of love in this journey to the final escape. It can even

\footnotetext{
${ }^{2}$ Victor Pelevin, The Sacred Book of the Werewolf, trans. by Andrew Bromfield (New York: Penguin Books, 2008), 239.
} 
be said that this book presents an almost classical example of the notion of liberation. Two main themes of the book are important for the analysis of the sacred - the notion of the superwerewolf and the concept of the Rainbow Stream.

Surprisingly, the protagonist of The Sacred Book of the Werewolf is a woman. Hardly, if ever, has Pelevin portrayed his female characters in an affectionate manner: Maria, who has a perverse romantic affair with Arnold Schwarzenegger (Buddha's Little Finger); the female vampire Gera (Empire V), whose head is cut off becoming the bodiless representative of the Goddess Ishtar; and Stepa's secretary and lover Mius (Numbers), who eventually runs away with all his money. Thus, Pelevin has not portrayed loving mothers, faithful wives or beautiful fiancées, and neither has he granted a happy ending to any of the relationships depicted in his books. ${ }^{3}$

In this context, A Hu-Li is the exception. In Pelevin's masculine world, where only men are granted an opportunity to discuss the meaning of emptiness and the universe, she is the one who achieves the final liberation and realises the significance of love. However, apparently Pelevin could not grant this role to an ordinary female. Therefore, A Hu- $\mathrm{Li}$ happens to be a 2000-year-old werefox looking like a 14-year-old girl, a Lolita of the postSoviet era, who works as a prostitute and practices meditation. ${ }^{4}$ She creates sexual illusions with her tail, thus absorbing man's life energy.

A Hu-Li meets Alexander, or Sasha, who is an FSB general (and at the same time an attractive werewolf). They end up in a mind-blowing love affair, playing erotic games by intertwining their tails. Their hallucinatory sexual encounters only prove the fact that the mind is the ultimate source of the sensual pleasures.

Sasha, despite being considerably younger than $\mathrm{A} \mathrm{Hu}-\mathrm{Li}$, can be regarded as symbolising the old Russia. He has even converted to Russian Orthodoxy and places a high importance on his duty to his motherland. ${ }^{5}$ Also, he represents a person who has successfully adapted to the new life in a post-Soviet era. At the same time, A Hu-Li represents a symbolic intertwining of Eastern and Western philosophies and postmodern nihilism. A Hu-Li, or Adele/Ada, as Sasha calls her is, on the one hand, a cynical werefox. But, on the other hand, during the course of the novel she transforms or, better, discovers the other side of herself that of a fragile and loving woman who, according to one modality of Bodhisattvas, decides

\footnotetext{
${ }^{3}$ Thus, for example, the romantic spark between Rama and Gera (Empire V) or Pyotr and Anna (Buddha's Little Finger) is doomed from the very start, and the potential relationships are unfulfilled. The only romantic encounter between Pyotr and Anna takes place in a dream-like state.

${ }^{4}$ Pelevin was not merciful creating a name for a fox. The name A Hu-Li stands for Russian obscenity, which can be translated into English roughly as "so fucking what?" (Pelevin, The Sacred Book of the Werewolf, X.)

5 As Sasha puts it, “you don't choose your faith. ... Just like you don't choose your motherland." (Ibid., 257).
} 
to postpone her own liberation in order to help her loved one. According to the Bodhisattva ideal, the aim of Buddhists is not to achieve nirvana in this life, but to return in the cycle of reincarnation to help others in this path. The realisation of the non-duality and of the notion of emptiness reinforces the attempts to reach this ideal. In this novel, love enhances $\mathrm{A} \mathrm{Hu}-$ Li's search for the ultimate transcendence.

This ultimate transcendence for the werefoxes is closely associated with the concepts of the super-werewolf and the Rainbow Stream. As it is said in the legend about the superwerewolf, he is the one that is supposed to appear in a city where the Temple is to be destroyed and then rebuilt. ${ }^{6}$ However, this legend has, as A Hu-Li puts it in the letter to her sister $\mathrm{U} \mathrm{Hu}-\mathrm{Li}$, to be understood as a metaphor. "The super-werewolf is what any of us can become as a result of moral self-improvement and the development of our abilities to the greatest possible extent. You are him already, in potential terms." ${ }^{, 7}$ In another letter she clarifies the matter. The city, according to her, is a metaphor of the soul, and a shrine - the heart that "has fallen under the power of evil and then returned to good." werewolf can be regarded as a messiah, who supposedly will atone for the sins of the foxes and purify their souls. But A Hu-Li insists that:

"No messiah will ever come to us were-creatures. But each of us can change ourselves by exceeding our own limits. That is the meaning of the expression 'superwerewolf' - one who has passed beyond his own boundaries, exceeded himself. The super-werewolf does not come from the East or from the West, he appears from within. And that is the atonement."

Here $\mathrm{A} \mathrm{Hu}-\mathrm{Li}$ refuses to hold the Christian notion of the messiah and instead interprets the super-werewolf in Buddhist terms, arguing that all the ultimate answers lie within. However, speaking with Sasha, she mentions that there can be several levels of understanding as to who is the super-werewolf. "At the most primitive one [level], he is the messiah who will come and tell all the were-creatures what the score is." The super-werewolf is also supposed to give the foxes The Sacred Book of the Werewolf, which "will reveal the

\footnotetext{
${ }^{6}$ According to the novel, Moscow fits that description.

${ }^{7}$ Pelevin, The Sacred Book of the Werewolf, 87. This quote perfectly coincides with Stephen Prothero's description of the one modality of emptiness: "The oddest implication of emptiness is that we are all already Buddhas. It is the dualistic mind that sees Buddhahood as something different from us. Move into nondualistic awareness and you will realize that you have been a Buddha since birth." Stephen Prothero, God Is Not One: The Eight Rival Religions That Run the World and Why Their Differences Matter (Melbourne: Black Inc., 2010), 195.

${ }^{8}$ Pelevin, The Sacred Book of the Werewolf, 129.

${ }^{9}$ Ibid., 129.
} 
central mystery of all were-creatures." ${ }^{10}$ However, besides being an external force, the superwerewolf is also a power accessible to all were-beings. This status is potentially available to everyone.

The notion of the super-werewolf is closely intertwined with that of the Rainbow Stream, which is depicted in The Sacred Book of the Werewolf as the ultimate escape. The secret teaching on the Rainbow Stream is presented to A Hu-Li by the Yellow Master, a Buddhist monk in China, some 12 centuries ago. The Yellow Master (who can be regarded as a kind of a spiritual master, an equivalent of Chapayev in Buddha's Little Finger) shares secret knowledge with A Hu-Li, which allegedly was told to a fox by the Buddha. This knowledge is permeated with Buddhist philosophy: "If you follow it, $\mathrm{A} \mathrm{Hu}-\mathrm{Li}$, you can not only save yourself, you can also show the way to liberation for all were-creatures living on the earth." 11 The Rainbow Stream, as the Yellow Master claims, is the ultimate goal of the super-werewolf, and, alternatively, to become the super-werewolf is to enter it. As the Yellow Master argues, it is impossible to describe the Rainbow Stream any other way:

"Both the Rainbow Stream and the path of the super-werewolf lie out of this world and are beyond the reach of the everyday mind - even a fox's. But they are directly related to each other. Therefore, it is only possible to speak of the former in relation to the latter. And of the latter in relation to the former." 12

The Yellow Master assures A Hu-Li that she is able to enter the Rainbow Stream; consequently, she then is the super-werewolf. However, the very notion of the Rainbow Stream is also ambiguous. It is the desirable liberation, but also an illusion (the same notion can be found in the description of Ural in Buddha's Little Finger):

"On the one hand, the super-werewolf is in the Rainbow Stream from the very beginning. But on the other, it is not possible to enter it at all, because the Rainbow Stream is simply an illusion. But this is only an apparent contradiction, because you and this world are one and the same."13

\footnotetext{
${ }^{10}$ Ibid., 262.

${ }^{11}$ Ibid., 303.

12 Ibid., 305.

${ }^{13}$ Ibid., 313.
} 
As A Hu-Li states, we create the world, and we create god. ${ }^{14}$ Therefore, eventually we might be able to stage our own escape from the world created purely by the power of our minds.

As it was already stated, feelings for Sasha inspire A Hu-Li to search for that ultimate liberation. After 2000 years of her life, this fox finally experiences love, which carries on a curious resemblance to that of emptiness. "Love was absolutely devoid of any meaning. But it gave meaning to everything else. It made my heart as light and empty as a balloon. I didn't understand what was happening to me. But not because I had become more stupid - there simply was nothing to understand in what was happening." 15 Eventually, with her love for Sasha serving as the main catalyst, A Hu-Li succeeds in finding the answer on how to enter the Rainbow Stream. She discovers three vital points.

"1) There was nothing in me that was stronger than this love - and since I was creating the world with my tail, there was nothing stronger in the entire world.

2) In the stream of energy radiated from my tail, and which my mind took for the world, love was totally absent - and that was why the world appeared to me in the way that it was.

3) Love was the key that I had been unable to find." 16

Thus, according to A Hu-Li, love (not to be confused with physical attraction, as she emphasises) is the key to the secret method of liberation, known as the "tail of the void". During the visualisation of love $\mathrm{A} \mathrm{Hu}-\mathrm{Li}$ finds herself on the threshold of the Rainbow Stream. However, similarly to Bodhisattvas, who make vows to work for the enlightenment of all sentient beings, the fox also decides to postpone her liberation, because she wants to share her experience.

This is how she depicts this experience:

"Suddenly something incredible happened. Inside my head, somewhere between the eyes, a shimmering rainbow of colour appeared. I did not perceive it with my physical vision - it was more like a dream that I had managed to smuggle in to the waking state. The shimmering was like a stream in the sunshine of spring. It sparkled with every possible shade of colour, and I could step into the caress of that kindly light." ${ }^{\prime 17}$

\footnotetext{
${ }^{14}$ Ibid., 315.

15 Ibid., 239. Or, to put it otherwise, love is the power capable to fill the emptiness: "If you think about it properly, there's nothing real anywhere,' I said. 'There's only the choice with which you fill emptiness. And when you feel happy for someone else, you fill emptiness with love.” (Ibid., 283.)

${ }^{16}$ Ibid., 319.

${ }^{17}$ Ibid.
} 
Eventually, realising that she cannot offer this secret of liberation to her lover, moreover, that Sasha does not even need it, A Hu-Li undergoes her journey alone. She jumps from a bike ramp in an attempt to enter the Rainbow Stream. Apparently that attempt proves to be successful, as The Sacred Book of the Werewolf is found later in Bitevsky forest and supposedly serves as A Hu-Li's instructions for those who want to follow the same path. By choosing to enter the Rainbow Stream, she refuses both the post-Soviet reality and the Western consumer culture depicted by $\mathrm{E} \mathrm{Hu}-\mathrm{Li}$ as a black hole in reality. ${ }^{18}$

What distinguishes A Hu-Li's journey from those of the other characters in Pelevin's books is the emphasis on love and its importance. This female protagonist offers the road of liberation, which is based on the concept of love. Interestingly, A Hu- $\mathrm{Li}$ also describes a method of liberation, designed specifically for "tailless monkeys", that is, human beings.

"First the tailless monkey must engender love in his soul, beginning with its most simple forms and gradually ascending to the genuine love that knows no subject and no object. Then he must review his entire life and grasp the futility of his goals and the villainy of his ways. And since his repentance is usually false and short-lived, he must shed tears for his own dark deeds at least thirty times. And finally, the monkey must perform a magical action similar to the one described in point three, but amended to take account of the fact that he has no tail. The tailless monkey must therefore first grasp how he creates the world and in what way he imposes the illusion on himself." 19

Although, as I will argue, the notion of love is one of the most important ideas in this novel, Pelevin is by no means sentimental or banal. Surely, the relationship depicted in this novel can hardly be called a traditional love story. Love here is a means to attempt to escape from this world, which is merely a construction of one's mind, and thus love is elevated to the sacred status. Earthly love is not enough in itself, but absolute love, as it is named in the novel Buddha's Little Finger, can grant a path to liberation. Even happiness and love, those two traditional aims that people strive to achieve, are overshadowed by the notion of the ultimate escape and liberation. A Hu-Li's choice clearly demonstrates that an escape from this world and the continuous striving for freedom prove to be the main themes of Pelevin's prose. Freedom comes from within, escaping all the constructions of the mind.

\footnotetext{
18 Ibid., 139.

${ }^{19}$ Ibid., 332.
} 
Freedom from everything created by the mind is also explicitly expressed in the novel Buddha's Little Finger, which is named by literary critics as a Buddhist novel, and as such needs to be further discussed in this thesis. ${ }^{20}$

\subsection{Emptiness as Absolute Freedom}

The novel Buddha's Little Finger is in the first pages ironically presented by the author as "the first attempt in the history of culture to embody in the forms of art the Mongolian Myth of the Eternal Non-Return."21 It seems that the attempt of the protagonist to reach the possible liberation is defined already from the very beginning. It is a novel about the journey which leads nowhere; it is an eternal struggle to find the destination and never reach it. It is not only a possible allusion to Mircea Eliade's notion of the eternal return, but also an eternal attempt of the writer to find the ultimate truth, which, as it seems, might never have existed. ${ }^{22}$

As Audun J. Mørch summarises, Buddha's Little Finger can be viewed in threefold way.

“(1) A post-modern text with a philosophical (or quasiphilosophical) emphasis on the relativity of all reality and objectification of the text itself. (2) An artistic thematising of Russian and Soviet mythology. (3) An expression of the emptiness, and loss of identity, felt by Russians and other peoples of the Soviet Union after the country ceased to exist." 23

The main character of the novel is Pyotr Pustota (translated from Russian, pustota means emptiness, or void), lost between the two worlds. In one of his realities, in the beginning of the $20^{\text {th }}$ century, Pyotr is a poet who accidently ends up becoming a commissar for the Red Army during the Russian civil war. In this world he meets a notorious Russian historical figure, Vasilii Ivanovich Chapayev, who in this novel is depicted as a spiritual

\footnotetext{
${ }^{20}$ Alexander Genis names it as 'дзен-буддистский боевик', which could be translated as a 'zen-Buddhist action novel'. (Alexander Genis, "Fenomen Pelevina," http://pelevin.nov.ru/stati/o-gen1/1.html (accessed August 20, 2011.)

${ }^{21}$ Pelevin, Buddha's Little Finger, VII-VIII. The epigraph for the book Buddha's Little Finger (supposedly Genghis Khan's words) brings a reader closer to the Mongolian tradition and illustrates the variety of sources for Pelevin's inspiration.

${ }^{22}$ Although, as Audun J. Mørch argues, "we can see why Pelevin changes Eliade's 'eternal return' to 'eternal non-return': Time is not really cyclic, nor is it linear, it is rather multidimensional." (Mørch, "Reality as Myth," 73.)

${ }^{23}$ Ibid., 79 .
} 
teacher and helps Pyotr to understand the nature of mind. In the other reality, at the end of the $20^{\text {th }}$ century, Pyotr is a patient in a psychiatric clinic, supposedly suffering from schizophrenia. His state betwixt and between can be attributed to his schizophrenic fantasies. However, Pelevin does not hint as to which of these realities is 'real', and which is imagined. This state of in-betweenness also explicitly demonstrates the state of the post-Soviet person, desperately trying to find his true identity. As Mørch notes:

"At one level at least, it is not difficult to understand the meaning of nothingness in the novel, or why it is important: when the Soviet Union disappeared in 1991, millions of Soviet citizens felt their world was gone. To be more exact the meanings of their former world were gone, perhaps felt to be 'stolen' and replaced by nothing, or if one prefers, by emptiness. The author makes no attempt to present the meaning of the book as a riddle that it takes close reading and deep thinking to solve. On the contrary, the basic meaning is obvious enough: Petr Pustota is a homo sovieticus, who when the Soviet Union is no more, finds himself in a void." 24

Also, as Pelevin shows in this book, these two worlds do not exist as totally independent realities. Both eventually appear to be created by one of the secondary characters of the novel, Kotovsky. Therefore, Pyotr's aim becomes to escape both of these worlds and to immerse himself in the emptiness. Also, as both realities are merely constructions of the mind, neither the Soviet nor the post-Soviet reality is treated as, in any sense, better or more valuable. It is not the freedom from the post-Soviet state that the protagonist seeks for his escape, but the absolute freedom, depicted in the Buddhist terms of emptiness. ${ }^{25}$

The clay machine gun, ${ }^{26}$ which Chapayev and Anna use to destroy the surrounding reality, serves as a powerful tool to transform the world. The principle of this gun is to point Buddha's little finger, which turns everything into the emptiness. Allegorically, here Pelevin points to Buddhist philosophy. Presumably only by understanding the nature of emptiness can people eventually become free from all of their reality's constraints.

Before discussing the concept of emptiness as depicted in Pelevin's books it is necessary to distinguish between the (Mahayana) Buddhist concept of emptiness, or śünyatā, and the Western notion of nothingness, as thoroughly discussed by the French existentialist

\footnotetext{
${ }^{24}$ Ibid., 64.

${ }^{25}$ As Krystyna Steiger notes in her doctoral dissertation, this book can be regarded as a threshold text on various levels, transcending the threshold between the Soviet and post-Soviet literary narrative: "as a threshold text one that both occupies and represents a certain middle ground or bridge of sorts, between historical periods and literary genres, and across various (extra-) literary modes of discourse." (Krystyna A. Steiger, Satire, Parody, and Nostalgia on the Threshold: Viktor Pelevin's Chapaev $i$ Pustota in the Context of its Times (PhD diss., McGill University, 2004), ix.) Steiger's work serves as an extensive study for the analysis of this novel and overall, of Pelevin's prose.

${ }^{26}$ The Clay Machine Gun is also a title of the novel Buddha's Little Finger for the UK audience.
} 
philosopher Jean-Paul Sartre. ${ }^{27}$ Sartre's nothingness, néant, is not a simple non-being. "Nothingness, Sartre argues, not only exists, but it exists within being, together with it and at the same time." ${ }^{28}$ Moreover, it is not simply a negative category. "Between what is and what could be there is a gap, an empty space, where man is free to choose. Nothingness is an empty moment in the world, where man is liberated from his past and has to choose. In this sense, Nothingness is the definition of freedom." 29 Nothingness is freedom - it is a multitude of choices. Freedom is only possible embracing this nothingness.

Japanese philosopher, Keiji Nishitani, states that the difference between Sartre's nothingness and the Eastern concept is the position of the ego. "Nothingness in Buddhism is 'non-ego', while the nothingness in Sartre is immanent to the ego. ... Nothingness may seem here to be a denial of self-attachment, but in fact that attachment is rather exponentialized and concealed. Nothingness may seem here to be a negation of being, but as long as it makes itself present as an object of consciousness in representative form - in other words, as long as the self is still attached to it - it remains a kind of being, a kind of object." ${ }^{, 30}$ Thus, as Nishitani argues, Sartre's freedom is still bondage; it is not an absolute emptiness. According to Nishitani, "true nothingness means that there is no thing that is nothingness, and this is absolute nothingness." 31

Nishitani defines śünyatā as emptiness which "empties itself even of the standpoint that represents it as some 'thing' that is emptiness. It is, in its original Form, self-emptying. In this meaning, true emptiness is not to be posited as something outside of and other than 'being.' Rather, it is to be realised as something united to and self-identical with being., 32 This is the notion which Nishitani entitles an "absolute emptiness" which appears as one with being. "The foundations of the standpoint of śūnyatā lie elsewhere: not that the self is empty, but that emptiness is the self; not that things are empty, but that emptiness is things." 33 And being such, it presents endless possibilities.

This feature is also mentioned by Guy Newland, a scholar of Tibetan Buddhism:

\footnotetext{
${ }^{27}$ This chapter will not further discuss nihilism as a philosophical doctrine. However, it is essential to mention the contribution of such philosophers as Søren Kierkegaard, Friedrich Nietzsche and Martin Heidegger to the development of this concept. This concept also has been revised by such postmodernist thinkers as Jacques Derrida, whose deconstruction is often regarded as nihilistic.

${ }^{28}$ András Bálint Kovács, "Sartre, the Philosophy of Nothingness, and the Modern Melodrama," The Journal of Aesthetics and Art Criticism 64.1 (2006): 136.

${ }^{29}$ Ibid., 136-137.

${ }^{30}$ Keiji Nishitani, Religion and Nothingness, trans. by J. Van Bragt (Berkeley: University of California Press, 1982), 33.

31 Ibid., 70.

32 Ibid., 97.

${ }^{33}$ Ibid., 138.
} 
"We can think of emptiness as like the clear, blue sky - a transparent space that is wide open. In that way, our empty natures mean that there is no limit to what we can become. ... Fundamentally, all things are empty - and so we are empty - of any intrinsic nature. This is why the reality of emptiness, properly understood, is a tremendous wellspring of hope and inspiration. Only because we are empty, the possibilities for what we can become are wide open."34

Emptiness opens up endless possibilities for transformation. This "reliance on nothing" is, as Nishitani notes, also absolute freedom. ${ }^{35}$ Stephen Prothero argues that śūnyatā was mistakenly seen in the West as pessimistic and nihilistic, whereas it should be understood as teaching of freedom rooted in experience. ${ }^{36}$ Through this profound realisation of fundamental reality, of the essence of emptiness, the path to freedom opens up - this is the door to freedom. By realising emptiness, one can be freed from suffering and any attachments. Hence unlimited compassion becomes possible. Realising emptiness is the letting go of everything, including oneself and the emptiness itself. Emptiness is closely related to non-duality, as the dichotomy of subject and object ceases to exist. Non-duality exists as an ultimate reality. "Thus one cultivates Buddhist practice to 'empty' oneself of delusions and passionate afflictions, and to 'gain' insight and compassion. One not only aims to attain wisdom for oneself, but to act compassionately for the sake of others. 'Being' and 'nothingness' are seen as mistaken extremes to be avoided., 37

Although it can be seen that both Sartre's nothingness and Buddhist notion could have common characteristics, the difference is that his nothingness is an engaged being, whereas śūnyatā is disengaged; it is a distance. The definition of nothingness as absolute freedom and possibility resonates with what Pelevin was trying to formulate in $T$ - that eventually absolute emptiness is an infinite possibility. ${ }^{38}$

In an attempt to understand Pelevin's unique position between East and West, Plato's Chariot allegory comes to mind. ${ }^{39}$ Even though this allegory explains the nature of the human soul, the conflict of rational and irrational impulses, here it can be used to illustrate Pelevin's aim to combine Western (intellect) and Eastern (combination of intellect and emotion) thinking. Pelevin's nihilism is not nihilistic by nature: it acts as beyond nihilism, as an

\footnotetext{
${ }^{34}$ Guy Newland, Introduction to Emptiness (Ithaca: Snow Lion Publications, 2009), 7.

${ }^{35}$ Nishitani, Religion and Nothingness, 160.

${ }^{36}$ Prothero, God Is Not One, 194.

${ }^{37}$ Paul L. Swanson, "Absolute Nothingness and Emptiness in Nishitani Keiji: An Essay from the Perspective of Classical Buddhist Thought," Eastern Buddhist 29, no. 1 (1996): 101.

${ }^{38}$ More about the novel $T$ - in section 7.4.

${ }^{39}$ Plato, The Phaedrus, Lysis, and Protagoras, trans. by J. Wright (London: Parker, 1848), 47-49.
} 
antidote to it. Thus Pelevin appears to be in the in-between position, between (or beyond) Sartre's nihilism and Buddhist philosophy, as a Western mediator. In other words, metaphorically, he is directing the entire post-Soviet nation, trying to stop the allegorical horses from going different ways and proceeding towards enlightenment. In this context the notion of journey that is used throughout this chapter gains additional colours and meanings. Pelevin's books are born out of the collision of the two schools of thought, that of the (post)modernist tradition and Buddhism. Also, it should be noted that his notion is alive and evolving with each subsequent book, as it will be seen in this chapter.

Upon further analysis it can be noted that Pelevin's notion of emptiness as depicted in Buddha's Little Finger significantly resembles śūnyatā. Throughout the entire story Pyotr engages in the hallucinatory search for the way out of the two worlds, in-between which he is stuck, and eventually - for emptiness. He attempts to grasp the meaning of that place or, better, space, that his mentor Chapayev names as Inner Mongolia, the Undefinable River of Absolute Love (Ural for short, a name for a river in Russia). This is how this river is described:

"The light it cast on the three of us was extremely bright, but there was nothing blinding or frightening about it, because it was also at the same time grace, happiness and infinitely powerful love. However, those three words, so crudely devalued by literature and art, were quite incapable of conveying any real impression of it. ... Or to be more precise, the rainbow-hued stream was everything that I could possibly think of or experience, everything that I could possibly be or not be, and I knew quite certainly that it was not something separate from myself." 40

Here, the merging of the subject and the object, the non-duality, is unambiguously described. This ultimate destination presents itself endless possibilities, a creation and recreation of the self. In a sense this destination is not something that is predestined or defined, but that is personally created and perceived and therefore appears to be different for each human being:

"Suddenly the thought struck me that since the very beginning of time I had been doing nothing but lie on the bank of the Ural, dreaming one dream after another, and waking up again and again in the same place. But if that were really the case, I thought, then what I had wasted my life on? Literature and art were no more than tiny midges hovering over the final pile of hay in the Universe."

\footnotetext{
${ }^{40}$ Pelevin, Buddha's Little Finger, 308.

${ }^{41}$ Ibid., 310.
} 
Hence Pelevin depicts the endless attempts of people to reach for what is out of reach, to go beyond one's own horizons, to discover ultimate truths and meanings. Endless repetitions of meaningless actions no longer seem satisfying or offer consolation through their comfortable forgetfulness. Here Pelevin dismisses the other forms of searching for meaning, such as creative work, as not fulfilling the ultimate desires. ${ }^{42}$

According to him, this Inner Mongolia, or Ural, is something that people knew but eventually forgot. It is a journey towards remembrance, not only understanding. "I felt as though the light reflected in his eyes had lashed me across the face; suddenly I was overwhelmed by total understanding and recall."

Inner Mongolia is described by Baron Jungern as a "place a person goes when he manages to ascend the throne to nowhere." ${ }^{44} \mathrm{He}$ also stresses that this place is nowhere, but it is not a place in a physical sense. One might call Inner Mongolia a state of mind or, alternatively, a refusal of the trap of the mind. Talking about this concept, Baron Jungern says that "it is quite impossible to say that it is located anywhere in the geographical sense. Inner Mongolia is not called that because it is inside Mongolia. It is inside anyone who can see the void, although the word 'inside' is quite inappropriate here."45 The influence of the Buddhist thinking here is obvious. It is also apparent, when in this novel it is repeatedly stated that absolute freedom can only be reached through embracing emptiness and liberating oneself from any traps created by the mind. Although the novel Omon Ra would let us surmise that when speaking of liberation and freedom, Pelevin has in mind, first and foremost, the freedom from Soviet or any sort of ideology, in Buddha's Little Finger, the post-Soviet reality is not treated any better than the Soviet world. For him both realities are merely constructs of the mind, represent different ideologies, and hence both are potentially dangerous. Possible salvation is to be found only in absolute freedom.

Realising the illusory nature of this world, Pyotr finally enters Inner Mongolia, which hence can be described as a state free of space-time and self. As Joseph Mozur claims, "Freedom is thus depicted as a deeply personal challenge and choice. Pelevin couches his hero's courageous feat of will power in a Buddhist context and calls upon humankind to dare to transcend the apparent and deceptive reality in which it is entangled."

\footnotetext{
${ }^{42}$ Although, alternatively, in the novel $T$ Pelevin uses the metaphor of writing, describing the process of the creation of the world. Such a personal creation appears to be the only meaningful act.

${ }^{43}$ Pelevin, Buddha's Little Finger, 300. The motif of remembrance is repeated in The Yellow Arrow and T.

${ }^{44}$ Ibid., 233.

${ }^{45}$ Ibid., 234.

${ }^{46}$ Mozur, "Viktor Pelevin," 61.
} 
For Pyotr, the realisation of the nature of emptiness means first leaving familiar territory, letting go of attachments, and letting go of his thinking about how society should function and of his own defined position in it. It also means undergoing the path of transformation and the acceptance of the temporality and ambiguity of all things. Letting go of attachments is a crucial element in understanding the Buddhist notion of emptiness, but Pelevin does not discuss it in a direct manner. Rather he emphasises the importance of freedom and the need for transformation (morphing characters in The Life of Insects is the most direct form of this transformation). Thus the path that he leads his protagonists consists of their transformation, their realisation of the true nature of emptiness, and eventually sharing their experience with others (hence the role of spiritual mentors such as Chapayev or Osiris in his books).

This notion of emptiness becomes even more significant in the post-Soviet context, when after the break-up of the Soviet Union millions of people found themselves in the void, in-between two historic periods and ideologies, with nothing left, not even their identity. This is not only a religious void, but the void of one's identity, personal history and personal destinations. Hence Pelevin's interest in Buddhism is not surprising. Joseph Mozur provides us with an explanation of the importance of Buddhism in Pelevin's works:

"Possibly one of the reasons for Pelevin's fascination with Zen Buddhism in his prose fiction is Buddhism's central belief in the impermanence of all things. Impermanence and change are viewed as neither good nor bad but as phenomena that must be embraced as normal. Given the social, political, and economic upheaval that has rocked Russia for the past ten years, Pelevin's message to his readers seems to be to strive to view those changes with equanimity."

The novel Buddha's Little Finger demonstrates that the void which emerged could be and is filled with another kind of 'sacredness' - that of this general category of freedom. Freedom (the escape to freedom) becomes the ultimate aim, and thus the potential source of what can be constituted as the sacred. Freedom and, at the same time, absolute love, whose importance in this novel is not emphasised as much as in The Sacred Book of the Werewolf, but which nevertheless plays a significant role, defines the ultimate destination - the Undefinable River of Absolute Love. Pelevin states that this freedom can be gained by fully realising the meaning of emptiness.

\footnotetext{
${ }^{47}$ Ibid., 63.
} 
Ironically, the person who Pyotr meets after the depicted realisation of emptiness, when eventually he comes back to the reality of the end of the $20^{\text {th }}$ century, is also the one who refuses to doubt this reality. Rejecting Pyotr's statements, the taxi driver denies the possibility of escape. Moreover he, as most people do, perceives this escape as negative:

"Pretending that you doubt the reality of the world is the most cowardly form of escape from that very reality. Squalid intellectual poverty, if you want my opinion. Despite all its seeming absurdity, cruelty, and senselessness, the world nonetheless exists, doesn't it? And all the problems in it exist as well, don't they?"48

The taxi driver here acts as Pelevin's alter ego: the one that constructs and at the same time deconstructs the reality and the text itself. As Pelevin said with his usual tongue-incheek attitude in one of the interviews, "I will try to explain what Emptiness is. Only you have to listen very carefully. So. [Keeps silent - Esquire] You have seen it just now. That's what it is." 49

\subsection{Monetary Freedom}

The previous sections can create the wrong impression that all of Pelevin's characters strive for indefinable, metaphysical destinations. However, this view would be one-sided and simplified. As mentioned at the beginning of this chapter, the ultimate morphing with monetary values can also become an attractive destination, as depicted, for example, in the novels Generation $P$ and Empire $V$.

Mark Lipovetsky rightly notices that Pyotr in Buddha's Little Finger and Tatarsky in Generation $P$ are antipodes:

"Pustota does not know which of the realities known to him are authentic and which are fictitious. But he chooses for himself the world where he is a decadent poet and Chapaev's Commissar, and follows this choice consistently. Tatarskii completely belongs to the given, that is today's reality. In order to escape from reality he needs to use different 'stimulators' like LSD, bad heroin, mushrooms, or at least a Ouija board for communication with spirits. Pustota follows the path of philosophic enlightenment and finally finds the capability to 'check out from the hospital', or in other words, follow the lead of Chapaev and create his own reality. Tatarskii also seems to go

\footnotetext{
${ }^{48}$ Pelevin, Buddha's Little Finger, 327.

49 Vladimir Vorobjev, "Pravila zhizni Viktora Pelevina," http://esquire.ru/wil/pelevin (accessed August 8, 2012).
} 
along the path of elevation, ranging from the 'larek' salesman to the live god, the head of the secret order, Haldey's Guild, which supplies Russia with illusory reality."

Paradoxically, both Pyotr and Tatarsky were once poets, and both turned their backs on their literary careers. As Pyotr chooses to search for emptiness as an ultimate expression of freedom, Tatarsky chooses its opposite - the world of material goods and seductive images produced by TV. However, his imaginary freedom is still limited despite his position of power - he can be free only within the illusory reality of advertising. ${ }^{51}$ In the case of Rama in the novel Empire $V$, he successfully adapts to the new vampire society and gains a position of power. Rama's story is also constructed as a certain coming of age passage. As Keith Livers notes, it is modelled on the bildungsroman. "Rama's progress in Empire $V$ passes through the various stages of self-discovery, from his first sexual encounter to his hard-won mastery of glamour and discourse acquired at novel's end." ${ }^{52}$ Here escape is constructed as a getaway from the gloomy reality of the post-Soviet life to becoming a member of the ruling elites, reaching the status of a living god. Rama appreciates his new position of power and takes the conformist stance. He no longer questions whether the freedom he has gained is sufficient and whether it is not limited. As he boldly states at the end of the novel:

"I love our empire style. I love its suffering-laced glamour and battle-hardened discourse. I love its people. Not for any bonuses or perks, but simply because we're of the same red liquid - though, of course, from different perspectives. I look at the state's oil rigs, sucking black liquid from the vessels of the planet and understand that I have found my place in the ranks." 53

Moreover, in this context of monetary values, freedom gains an additional meaning. Freedom appears to be just another commodity to be sold at a highest price. People are encouraged to gain their freedom by consuming more and more goods which supposedly make them successful, happy and free. Advertising promises the feeling of absolute content, freedom and meaning not just in the distant future, as in the case of following certain spiritual

\footnotetext{
${ }^{50}$ Mark Lipovetsky, "Russian Literary Postmodernism in the 1990s," The Slavonic and East European Review 79, no. 1 (2001): 44.

${ }^{51}$ The same can be said about Rama in Empire $V$, who eventually becomes one of the most influential members of the vampires' society due to his friendship with the new representative of the Goddess Ishtar. However, freedom here can hardly be discussed as Rama has not become a vampire by his own free will, and cannot leave the vampires' clan. Joining the outsider Osiris, who can be regarded as a sort of Rama's spiritual mentor, does not seem an attractive option for him either.

${ }^{52}$ Livers, "The Tower or the Labyrinth," 496.

${ }^{53}$ Pelevin, Empire V, 406.
} 
or religious traditions, but here and now, after purchasing and consuming material goods. ${ }^{54}$ The main focus point in Generation $P$ is that which Sally Dalton-Brown named as the "empty desire." 55 All human life is directed towards the satisfaction of the three cravings (oral, anal and wow impulses), which all reflect the essential craving for money.

As it was already mentioned, this research holds the monetary sacred as equally important. The value judgements come from the Judaeo-Christian viewpoint; enough to remember the well-known passage "You cannot serve both God and Mammon" (Matt. 6:1924). From this theological point of view, Philip Goodchild argues that money became a dominant global religion, the transcendent principle of the social order, the supreme value. For him, god has been replaced by money as the source of power, transcendence, truth, goodness and freedom.

Hence how he sees this dichotomy of money and god:

"It is easy to observe how this shift naturally leads to secularization and a direct opposition between God and money. Where God promises eternity, money promises world. Where God offers a delayed reward, money offers a reward in advance. Where God offers himself as a grace, money offers itself as a loan. Where God offers spiritual benefits, money offers tangible benefits. Where God accepts all repentant sinners who truly believe, money may be accepted by all who are willing to trust in its value. Where God requires conversion of the soul, money empowers the existing desires and plans of the soul. Money has the advantages of immediacy, universality, tangibility, and utility. Money promises freedom and gives down payment on the promise of prosperity." 56

There is no reason why this monetary sacred in Pelevin's prose should be treated as worse or 'degraded'. Money exercises a special power. It shapes people's desire and striving, forms their identity, meaning, truth and faith. Monetary satisfaction becomes the most important goal and aim for the protagonist in this novel. Metaphorically it can also be called the Inner Mongolia, the Rainbow Stream or the Optina Pustyn of consumer society. ${ }^{57}$

Optina Pustyn is a concept presented in the novel $T$ and, as the title of the following section indicates, it can be called the ultimate destination not only in this particular novel, but in Pelevin's creative work in general.

\footnotetext{
${ }^{54}$ This is what E Hu-Li in The Sacred Book of the Werewolf depicted as a black hole in the reality of Western consumer culture. "Do you know what the secret horror of life here is? When you buy yourself a blouse or a car, or anything else, you have in your mind an image, implanted by advertising; of some wonderful place you will go wearing that blouse of driving that car. But there is no such wonderful place anywhere, apart from in the advertising clip, and this black hole in reality is lamented by every serious philosopher in the West." (Pelevin, The Sacred Book of the Werewolf, 139.)

${ }^{55}$ Dalton-Brown, "The Dialectics of Emptiness," 245.

${ }^{56}$ Philip Goodchild, Theology of Money (Durham: Duke University Press, 2009), 11-12.

${ }^{57}$ Same goes for Empire $V$ - here the consumption of bablos provides the ultimate satisfaction.
} 


\subsection{Optina Pustyn as the Ultimate Destination}

As mentioned, Pelevin's books can be said to be based on the same core narrative structure. ${ }^{58}$ However, speaking of the novel $T$, some critics are reluctant to call it fiction. ${ }^{59}$ As Martin Ganin states, everything that Pelevin wrote after Generation $P$ cannot be called books in the usual sense of this word, but artefacts. ${ }^{60}$ His works are rather a quasi-philosophical discourse on metaphysical searching and ultimate truths, an attempt to question the nature of the universe and of the human lost in it. This search for possible answers is reflected in a number of his books, but most clearly expressed in the novels Buddha's Little Finger and T.

The novel $T$ is closely linked to Buddha's Little Finger not only because here a young Chapayev appears as one of the secondary characters. At the end of the novel Count T. eventually decides to go and find Chapayev, thus proving that in this book the latter takes up the role of a spiritual mentor as well. Even more, the novel $T$ continues the discussion about the true nature of the universe and the emptiness that had already been started in Buddha's Little Finger. Some reviewers, for example, Lev Danilkin, state that the novel $T$ was actually born out of one episode of Pyotr's hallucination in Buddha's Little Finger. ${ }^{61}$

It is not surprising that the $19^{\text {th }}$ century Russian writer Leo Tolstoy served as a prototype for the Count T. in the novel $T$. The usage of Tolstoy is an example of Pelevin's deconstructive technique, which was mentioned in the fourth chapter. However, this is how Pelevin himself comments on this novel:

"This book is absolutely not about Tolstoy - he appears there for a short time, only in one chapter. This book is about an abstract journey (emphasis mine), which some people succeed to take in life. It was interesting for me to draw a map of such a journey, the signs of which correspond to certain elements of reality known to me. And the choice of the character - Count T. - is a big mystery for me too ... I like Leo Tolstoy from my childhood. I was always fascinated by the strange beauty of

\footnotetext{
${ }^{58}$ There are even predictions that Pelevin eventually will end up writing a book that could be read only by those who can clap with one palm. (Michail Budaragin, "Vremia T," http://actualcomment.ru/daycomment/299/ (accessed June 30, 2011.)

${ }^{59}$ For example, Dmitrij Bykov, as quoted in Dmitrij Proskuriakov's article. (Dmitrij Proskuriakov, "Naidi v sebe chitatelia, ili metafizika i ontologija teksta," http://www.pelevin.info/pelevin_148_0.html?page=3 (accessed August 21, 2011.)

${ }^{60}$ Martin Ganin, "Viktor Pelevin. T,"

http://www.openspace.ru/literature/events/details/13262/?expand=yes\#expand (accessed June 30, 2011).

${ }^{61}$ Lev Danilkin, “T-obraznyj tupik,” http://www.afisha.ru/book/1570/review/298339/ (accessed June 30, 2011).
} 
Tolstoy's death, that exit of his from home to eternity. It is evident that he actually reached his own Optina Pustyn."62

The meaning of Optina Pustyn can be described using analogies from Pelevin's earlier texts. ${ }^{63}$ The role and the meaning of this space in the novel $T$ is arguably the same as of Inner Mongolia, the Undefinable River of Absolute Love and the search for emptiness in Buddha's Little Finger or the Rainbow Stream in The Sacred Book of the Werewolf. ${ }^{64}$ It can also be argued that getting off the train in The Yellow Arrow carries on some resemblances, although it is not of exactly the same nature. ${ }^{65}$

The novel $T$ opens up in the liminal sphere - the train, where the two characters, the salesman Knopf and father Paisij (that is, Count T.), meet. It can also be claimed that this novel itself is based in a certain liminal zone, not even between the two worlds, but between several worlds. The author does not give the answer as to which one of those worlds is true and real. Here the notion of reality itself is deconstructed. ${ }^{66}$ Also, a significant part of the scenes in the novel take place in liminal zones: on the train, in the state of sleep, in the emptiness, in the twilight zone between life and death. Dostoevsky's Petersburg emerges here as a grotesque metaphor of the contemporary city with dead men walking.

During the course of the novel Count $\mathrm{T}$. finds out that he is actually not a real human being, but a character from the draft of the book being created by Ariel together with a team of authors who are paid to write a bestseller. However, Count T. starts to doubt whether Ariel is telling him the truth, begins to question his claims and eventually attempts to become an author himself, while at the same time trying to find out what Optina Pustyn is.

The concept of Optina Pustyn remains ambiguous and unclear. Pelevin leaves a space for his readers to create additional meanings as of what it means to them. He leaves blank spaces to be filled with the readers' imagination and their possible beliefs that would correspond to their personal belief systems. As one of the characters Olsufiev says in the

\footnotetext{
${ }^{62}$ Vasilij Vladimirskij, "Tolstoj i pustota," http://www.mirf.ru/Reviews/review3953.htm (accessed June 30, 2011).

${ }^{63}$ Optina Pustyn is also a name for an Eastern Orthodox monastery for men in Russia, which in the $19^{\text {th }}$ century served as the most important spiritual centre of the Russian Orthodox Church. (http://www.optina.ru (accessed August 23, 2011.) Translated from Russian, Pustyn (nустылнь) means desert, and has clear associations with the word nycmoŭ, meaning empty.

${ }^{64}$ Dmitrij Proskuriakov, "Naidi v sebe chitatelia, ili metafizika i ontologija teksta," http://www.pelevin.info/pelevin_148_0.html?page=3 (accessed August 23, 2011).

${ }^{65}$ Possibly because it is one of Pelevin's first books, and hence the concepts which emerged here and in Omon $R a$ were further developed in his subsequent works.

${ }^{66}$ The notion of time is also unclear and ambiguous. Count T., as the fictional Leo Tolstoy, is supposed to be living in the $19^{\text {th }}$ century (the 'real' Leo Tolstoy was born in 1828 and died in 1910). However, T. is not bound in any categories of time. He moves freely from the $19^{\text {th }}$ century to the world of his supposed author Ariel, who is living in the post-Soviet era.
} 
novel $T$, Optina Pustyn is god, noting that he uses the notion of god simply because it is the shortest word known to him, which directs one to the sphere that is beyond any words. ${ }^{67}$ This is the place where a person meets god - or becomes god himself. ${ }^{68}$ The human's ability to occupy the place of god, to become a creator himself, is a repetitive motif in $T$, and is also conveyed in a metaphor of the author.

Count T. attempts to reach Optina Pustyn, although he does not remember why he has to go there and what even this place is (allegedly because of his contusion, although the reader later can find out that he was given mind-altering substances). This ignorance of where he is going, as well as the reason and final purpose, metaphorically reflects every human's journey through life in search of their personal meanings. Optina Pustyn can be regarded as a symbolic depiction of the final point of every (spiritual) journey or, to put it in terms of this research, of every escape - the bottom line of everything sacred.

The novel $T$ also offers a paradox. Although Pelevin depicts various modes of escape in his novels, including psychedelic drugs, alcohol, and TV-generated reality, he nevertheless refuses to provide the readers the very escape that they actually search for while reading the book, namely, immersing in the text and forgetting their own reality. He does not let the readers forget that they are reading; that at this particular moment of reading they are creating a certain reality in their own imagination. He questions the meaning of creation and authorship and invites the readers to do the same, not letting them become a passive entity (as in the case of a person's escape from reality while watching TV). Pelevin urges the readers to participate in the act of creation by becoming creators - to fill the gaps of the book with their own content. He summons his readers out of the state of non-thinking and asks them to think and to question the surrounding reality, the book which they had just opened. In fact, he asks readers to question the very concept of 'Pelevin' as the author of the book. By refusing to give his readers a blissful escape into the fictional world (this is being done by constantly demonstrating the acts of creation and re-creation, by deconstructing all the myths of authorcharacter-reader and the writing itself) and by torturing them with hundreds of pages of quasi-philosophical dialogues and streams of consciousness, he provides the readers with an opportunity to question their own lives. In this case, Optina Pustyn is not only a metaphysical space which Count T. attempts to reach, it is also Pelevin's trick which makes the readers ask who is the actual creator of their life or whether they are also just characters, being created and manipulated by certain powers, which manifest themselves as god-like figures or

\footnotetext{
${ }^{67}$ Viktor Pelevin, $T$ (Moskva: Eksto, 2009), 264.

${ }^{68}$ Ibid., 265.
} 
ideological programmes. Pelevin basically repeats the old notion, which can be summarised in the atheist's favourite question of 'Who designed the Designer?' This notion might sound banal, but literary mastery helps Pelevin keep the fragile balance between banality and novelty. This book appears to be 'a novel about the novel', about the act of writing and creating, and about the eventually faced impossibility to express the most important concepts in words. This is because the words, drawn out of the emptiness, seem to disappear in that emptiness over and over again.

In the novel $T$, Victor Pelevin eventually comes to the conclusion that the world as such does not exist. There are just movements of the hand in emptiness in an attempt to create one's own world. Thus the entire objective world is just the creation of each individual. This is the final disillusionment with any religious, spiritual or ideological system: just the return to a human being and their ability to create. This is also an ultimate acceptance of freedom in this particular case, the freedom to create, to become the author of your life, and to accept that - perhaps - life has no meaning. This episode, as mentioned, resonates with the main characteristics describing the notion of nothingness both in Sartre's philosophy and in the Eastern notion of emptiness. The novel ends with an episode where Count T. heads to Chapayev. Here Pelevin makes an elegant movement towards the 'eternal return' - coming back to his unresolved questions and showing that they might be unsolvable.

\subsection{Conclusions}

"I realised once and for ever that only weightlessness could give man genuine freedom," Omon states in Omon Ra ${ }^{69}$ Even the West, the promised land for Russian people, or the resistance to the existing regime could not grant him this state. ${ }^{70}$ The ending of the book explicitly shows the difficulty, if not impossibility, of finding genuine freedom in this earthly world. Symbolically, Omon continues his journey; Pelevin also continues his journey towards the search for freedom, which had begun with this first novel. Starting with the physical description of freedom as weightlessness, in the subsequent books he supplements it with such characteristics as ultimate liberation (A Hu-Li in The Sacred Book of the Werewolf, Pyotr in Buddha's Little Finger, to a certain extent - Count T. in T). Alternatively, this sacred

\footnotetext{
${ }^{69}$ Pelevin, Omon Ra. Zheltaia strela, 12.

${ }^{70}$ Ibid.
} 
journey can be regarded as an ultimate morphing with monetary values (Tatarsky in Generation P, Rama in Empire V).

Escape to freedom, as seen in Pelevin's prose and as metaphorically expressed in the Buddhist notion of enlightenment, can actually signify the real journey, that of the postSoviet people entering the unknown zone of freedom. The motif of this journey symbolises the state of the post-Soviet people depicted by Pelevin, transiting from the Soviet to the postSoviet state and framing their new identities. This motif reflects their state of in-betweenness, and the relative and temporary nature of their newly forming sacreds.

Freedom here presents itself as a sacred category, both as the destination and the journey (being on the road, in the liminal state, where that striving for the sacred can be actualised). However, it is also an ambiguous category. This ambiguity is expressed in the feelings of nostalgia for the past, as mentioned in the sixth chapter. For a significant part of the post-Soviet people, freedom is an alien and scary category, and they long for security, clarity, and the eternity of the Soviet past. This confirms the hypothesis of the first chapter that the sacred in the contemporary milieu is a relative and temporary category.

Following their journeys, the protagonists eventually reach the point, which can be named, in separate cases, the ultimate transformation, liberation (The Sacred Book of the Werewolf, Buddha's Little Finger, T), or the eternal return (in a sense - Numbers). For example, the morphing characters in The Life of Insects also express the desire for the ongoing transformation. They are on a road, which eventually could lead to the ultimate transformation. In other words, the protagonists are in the transition period (from nowhere to no place). ${ }^{71}$

A Hu-Li, Pyotr and Count T. can be regarded as having reached the desired transformation (the understanding of emptiness and the illusory nature of this world) and the state of freedom (freedom to create their own reality or to ultimately escape that reality). A $\mathrm{Hu}$-Li presents an almost classical version of liberation, which could be achieved through the understanding of the true nature of love. Tatarsky and Rama, paradoxically, also reach their desired state. They successfully adapt to the society that they are living in, gain a position of power in that society and reach the monetary sacred (although, at least in the case of Tatarsky, this position does not bring the results that the protagonist had craved for). However, it can be said that, for example, Stepa from Numbers at the end of the novel returns to the same point that he was at the beginning, and starts on the same road again, based on his

\footnotetext{
${ }^{71}$ It is also an allusion to the title of Pelevin's book DTP $(N N)$ - The Dialectics of the Transition Period (from Nowhere to No Place) (2004).
} 
belief in the sacred number. ${ }^{72}$ Although Stepa could have been regarded as having a potential to absolutely transform his life after losing everything (including his wealth, business and a romantic partner), instead of realising the relative absurdity of his faith he decides to follow the same path, repeating this over and over again - hence the eternal return. ${ }^{73}$ The novel Numbers in this sense reminds us of the short story Initiation from The Life of Insects. Here the young boy's questioning about the meaning of life and universe ends in the final embrace of the old truths told by his father and in the endless repetition of the same pattern of thinking and behaviour. ${ }^{74}$ The door to freedom hence remains closed. Both Omon and Stepa at the end of the novel have to take a new road. But while Omon's new road is optimistic, promising, and chosen freely, Stepa's remains in the closed circle constructed by his mind. ${ }^{75}$

As the analysis in this chapter has demonstrated, freedom appears to be a crucial element of what the sacred is for a post-Soviet person, as depicted in Pelevin's texts. There can be several explanations of this importance. First, it is a counter-reaction against all the ideologies that were forced on people throughout the years and centuries, be they religious or political regimes (Communist ideology, Western consumer culture). This striving for freedom seems even more important, given the long history of suppression in the Soviet (and preSoviet) state. Secondly, it is a general tendency of a postmodern person to strive for liberation of any constraints and limitations set by society. In other words, it is an attempt to rewrite the world in which we are living, to provide it with the meaning that would be satisfactory for the postmodern person who apparently has lost the ability to believe in the old forms of the sacred. Pelevin is allergic to any kind of ideology and explicitly shows it with his critique of both Soviet and post-Soviet life, both of Communist and capitalist ideology. He does not even avoid criticising his favourite Buddhism or at least certain parts of Buddhist philosophy, thus showing his disapproval of any restrictions in one's individual search for the sacred. Thirdly, there is Pelevin's revised notion of emptiness. This notion, as was discussed, remains in-between the Western and Buddhist notions. The realisation of emptiness is equal

\footnotetext{
${ }^{72}$ At the end Stepa decides to choose another number and apparently creates his new life based on worshipping his new favourite.

${ }^{73}$ It can be difficult to interpret Stepa's life in general as a journey, although, on the other hand, what can be named as a journey for him can be a striving for a material success and a faithful devotion to the number 34 .

${ }^{74}$ It is evident from this story that Pelevin's version of the myth of the eternal return can be potentially dangerous and leading nowhere. The eternity, as Keith Livers rightly notices, is metaphorically presented in an image of the circle or ball, one possible example being the dung ball in the short story Initiation. (Livers, "Bugs in the Body Politic," 7.) The young boy begins his journey questioning the meaning of life, but eventually merges his life with that mythologised dung ball and enters the circle of eternal return with no hope of escape.

${ }^{75}$ It might be misleading here to regard his 'journey' as a failure. But it is necessary to note that from all the protagonists mentioned in this analysis only Stepa can be regarded as in a sense a 'non-liminal' character. He perfectly fits into the description of an ordinary post-Soviet person - a successful businessman thriving in corrupt, contemporary Russia.
} 
to ultimate freedom. Emptiness can also be seen as born out of the avoidance of any ideologies, as a restriction-free zone, and as an endless possibility. Pelevin's personal interest in Buddhist philosophy is clearly expressed in his books and creates an attractive Eastern aura for both the Russian and Western reader. This striving for freedom appears to be inscribed in the DNA of Pelevin's texts and constitutes the sacred for the characters depicted in them. Mentioning all the urban legends surrounding Pelevin (including those claiming he is a group of authors or just a myth himself), Stanislav Gurin jokingly mentions the most radical hypothesis, that Pelevin is "a collective hallucination in the consciousness of his readers, virtual reality or Emptiness itself.",76

In this escape, the striving for immortality can also be ascertained. The choice of such immortal or semi-immortal characters as vampires or werewolves reflects both the desire for immortality and the understanding of the inevitability of facing death. These characters transgress the previously sacred and untouchable boundaries of life and death and reinvent their understanding. As traditional religious beliefs are no longer valid and no longer provide satisfactory answers to the essential questions on the nature and meaning of life and death, consolation regarding these major questions has to be found somewhere else. In this milieu of the temporality and uncertainty, the new sacred ground has to be created and the new mythology invented to frame people's life and provide them with explanations. Ultimately, the sacred is escape: it is escape from the world falling apart, a hope for the eternity, a striving for something higher and more important than the human being, a craving for the ultimate world explanation. Pelevin's prose helps to disclose the mutual interdependency of these two notions.

\footnotetext{
76 Stanislav Gurin, "Pelevin mezhdu budizmom i christianstvom," http://pelevin.nov.ru/stati/o-gurin/1.html (accessed September 27, 2011).
} 


\section{Conclusion}

"In my opinion, a happy ending is the best thing that can happen in literature and in life. In general, I have a persisting aspiration for a happy ending. The thing is that literature to a large extent programs life, at any rate, the life of the person who is writing. I have tested this on myself many times, and now think ten times before I send some secondary character somewhere."

During a virtual Internet conference Victor Pelevin was asked why he had created such an ending for the novel Buddha's Little Finger, which is reminiscent of the typical banal American-style happy endings. His answer eloquently hints that the aforementioned postmodernist nihilism in his works is permeated not only with an effort to construct happy endings, but also with a hope that the ending is a construct in itself. There are no beginnings and endings, only a human's journey to escape the eternal (non) return.

This conclusion briefly summarises what has already been stated in this research. It provides insights into the role of the sacred in Pelevin's prose and beyond; it introduces new possible approaches towards his writings and his position in Russian literature and, finally, it presents trajectories for future research.

\section{The Post-Soviet Sacred: New Interpretations}

This research used the concept of the sacred for the analysis of Pelevin's prose in order to disclose various modalities and to grasp what is sacred in post-Soviet society. In this research, the concept of the sacred was held to be a technical term for scholarly study, not necessarily directly related to religion, not a universal term, and not a permanent or unchangeable category. The sacred was regarded as a relative and temporary phenomenon, which is constructed through certain cultural practices and traditions and first and foremost helps us to disclose the concepts of meaning, identity and community in contemporary society through the individual reactions, perceptions and behaviour directed to that which is perceived as sacred.

Such a tool was applied to analyse Victor Pelevin's prose with the intention of seeing whether such a concept could be useful when discussing contemporary literature or, in other

\footnotetext{
${ }^{1}$ Author unspecified, "Virtualnaja konferencija s Viktorom Pelevinym," http://pelevin.nov.ru/interview/opeirc/1.html (accessed July 25, 2011).
} 
words, to reject the notion that 'nothing is sacred'. Therefore, the example of the most 'secular' society and prose was chosen. For the analysis, this research classified the manifestations of the sacred into conventional and non-conventional, and discussed such categories as ritual, sacred space, sacred persons, liminality, and the modes of escape. As well as the concept of the sacred, these categories were used beyond their religious contexts.

Pelevin's Russia has been going through an intense time of huge personal and social transformations, of drawing new spiritual maps, and of marking new sacred territories. The findings of this research show that what is taking place in the post-Soviet era is a radical rethinking of sacrality, and Pelevin has been serving as a prophet for the era of the new sacrality. His works reflect the longing for the sacred, that is, its previous stability and clarity, and at the same time the realisation of its relativity. Pelevin can be regarded as the embodiment of the post-Soviet transformational stage, and his works are an illustrative example of this transformative experience, creating and deconstructing the sacred simultaneously.

Generally Russian critics tend to regard Pelevin as a pop-writer. This attitude came from the legacy of Russian literature, and a general understanding of 'literature as religion', the remembrance of which still operates in the post-Soviet milieu. Not surprisingly, Pelevin is not too popular amongst the conservative Russian critics, as his works present the deconstruction of the previous (sacred) literary forms. However, I would argue that he is much more than a pop-writer. In Russia, Pelevin is more than a writer; rather, he has become a sacred figure, an icon for a significant number of people, and his books shape new ideological structures and become a source for creating the new sacred(s). Also, Pelevin, as a cultural icon and a sacred figure fosters the creation of new communities, united by this quest for the new sacred. Pelevin does not only write about post-Soviet reality - his books ultimately form and influence that reality by spreading new and provocative ideas.

This tendency contradicts the critics who claim that the role of the writer in postSoviet society no longer carries on the same importance as in the pre-Soviet times. Even though Pelevin-as-a-writer's reception is variable and ambiguous, nevertheless he is one of the most important authors of the $21^{\text {st }}$ century. Even though Russian literature might no longer 'inspire or heal', contrary to some critics, such as N.N. Shneidman, I would argue that Pelevin is neither indifferent nor a heartless observer of contemporary Russia. He is deeply engaged, and his prose unambiguously reflects the painful state of in-betweenness where Russians found themselves after the break-up of the Soviet Union. However, it is true that being a popular and commercially successful author, Pelevin presents a challenge to those 
traditionalists who still long for the great ideals of $19^{\text {th }}$ century literature. His prose might be a "haphazard collage", written "in poor literary Russian and littered with slang and foreign words", ${ }^{2}$ but this only reflects the general condition of the $21^{\text {st }}$ century, its unstable ground and postmodernist search for the new forms of expression. That said, Russian critics and readers have higher expectations as to Pelevin's prose, hence the criticisms. While foreign readers and critics notice the exotic features of the post-Soviet reality, Russian readers see themselves accurately portrayed in his works.

Russian identity in Pelevin's prose presents itself as a deconstructed Soviet identity. This research also noted that it is difficult, if not impossible, to start the new chapter of 'Russianness', if people keep re-reading the last one. Namely, the problem of the absence of 'de-Sovietisation' was noted, and that is an important reason why the concept of Russian identity remains problematic. Instead of repentance or the rejection of the Soviet past, Russians tend towards escapism or denial. Pelevin's works show the ambiguity of the concept of freedom in the post-Soviet mentality.

Beyond doubts, in his prose 'Russianness' is no longer held as a sacred category. But nevertheless this Russianness is more important to Pelevin than it seems, or than the writer himself admits. His prose is 'Russian': the time, space, the protagonists, and the problems analysed; the pre- and post-Soviet condition that is dominant in it; the role that alcohol and nostalgia hold in his works; the development of the notion of suffering; the influence of the shamanic culture; the notion of Optina Pustyn, unambiguously pointing out not only to the Buddhist, but also to the Orthodox Church context. Even depicting imaginary societies, that of the vampires, werewolves, or Chaldeans, Pelevin uses those as metaphors for the current post-Soviet state. Hence what Russian critics loathe to admit is that his is a voice for a generation. Moreover, the dualities presented in Pelevin's prose are not only that of the Eastern (Buddhist)/Western traditions, but also that of Western/Russian (Orthodox), or Eastern/Russian.

Pelevin seems to be internalising the debate about Russian identity. At the core of Pelevin's prose is the tension and struggle to define it. Pelevin's prose reflects Russia's plurality and the search for Russian identity. However, Russian identity is not to be understood narrowly. The broad trajectories in post-Soviet Russia - consumerist culture now coincide with the general Western tendencies. Of course, this plurality of Russian

\footnotetext{
${ }^{2}$ Shneidman, Russian Literature, 1995-2002, 12-13.
} 
identity poses a problem. But because of this plurality, the new sacred, as discussed in this research, is a more universal concept.

For the Russian audience, Pelevin is very, and may be too, Western. For his Western audience, Pelevin embodies the post-Soviet spokesperson. In fact, although he addresses the post-Soviet reality, in many ways he resonates with the contemporary West. Because of this ambiguous position, the sacred as reflected in his works appears more universal and could not be narrowed down as only relevant to the 'post-Soviet sacred'.

Thus the findings of this research are useful when discussing not only the concept of the sacred in post-Soviet literature and reality, but also in the contemporary world in general, disclosing its main sacral tendencies. As a writer, Pelevin creates new contexts for the discourse of the sacred. The analysis of his works reflects the fact that this redefined notion of the sacred is essential in the studies of sacrality in the postmodern world. The redefined concept is useful in a wide variety of contexts.

Also, Pelevin as pop-Buddhist's reception is incorrect; and incorrect is his narrowing down to only Mahayana Buddhism, or Zen Buddhism. This frequent mistake comes from critics who generally are not very familiar with the Buddhist philosophy. I would argue that Pelevin's works present a postmodernist collage of various Buddhist traditions and interpretations, and a researcher would have to be an expert of Buddhism to adequately interpret all his allusions. Moreover, Pelevin's 'Buddhist' views are evolving and changing with each subsequent book, which also makes it more difficult for a researcher to generalise and to label Pelevin simply as a 'Buddhist' or 'pop-Buddhist'.

\section{Victor Pelevin: Deconstructing the Sacred}

Pelevin's works deconstruct Soviet mythology and what was held sacred, and also deconstruct the post-Soviet - or consumer society - and the monetary sacred. These modes of the sacred prove to be no longer satisfactory. However, as noted, after such deconstruction, the upcoming void can serve as productive ground in the search for new forms of the sacred, which proves to be useful.

An inevitable outcome of the post-Soviet situation, as mentioned, is the feeling of inbetweenness: a liminal situation, an existence between the old system being destroyed and the new order yet to be created. The post-Soviet era no longer provided the universal and eternal notion of what is sacred, yet it presented a new challenge to create the new sacred, which at 
this point might be neither universal nor eternal. As such, it confirms the value of the revised definition of the sacred that this research has presented.

The liminal, in-between situation of post-Soviet Russia encouraged the search for the new sacred and sharpened the desire to find a stable ground, to find a new identity, meaning and truth. This search, which could be conditionally named as "the eternal return of the sacred", in Pelevin's prose is expressed through: the protagonists' engagement with both traditional religions and new, exotic spiritualities; striving for the monetary sacred; experimentation with the new forms of relationships - both social and intimate; creating new communities and societies; the sense of nostalgia; and through the modes of escape.

Finding themselves in a liminal state, Pelevin's protagonists encounter sacred persons - those spiritual masters or god-like figures. This would prove the argument that in the liminal state the search for the sacred can be actualised. The liminal position of the protagonist can facilitate their involvement in the search for the sacred. Liminality actualises the need to search for the sacred; it inspires and empowers. The liminal spirituality (or, in Benedikter's terms, a productive void), that is a dominant feature of the post-Soviet condition, further strengthens that need.

Pelevin's prose actively promotes the idea of the plurality of the sacred, or the idea of the possibility of having 'nothing sacred'. Throughout his writings he explicitly shows how the concept of the sacred is relative, temporary, unstable and deeply personal. Moreover, he even shows in a postmodernist manner the possibility of no sacred - and the personal creating of the sacred out of the postmodernist (productive) void that I have already defined as a concept specific to Pelevin, as being in-between Eastern and Western notions of emptiness/nothingness, combined with a liminal post-Soviet situation. This plurality of the sacred presents yet another challenge formulated by this research, which is finding a way to live in the world with many different sacreds.

As mentioned, Pelevin's work can also be defined as simultaneously creating and deconstructing the sacred. An analysis of ritual (initiation and sacrifice) helped to track Pelevin's deconstruction gesture: he also deconstructs the traditional understanding of these notions. Initiation, as a necessary step en route through the transition to the higher level, fails to keep its promises. Thus sacrifice, always required and performed, also appears to be purposeless. This finding encourages revisiting the theoretical assumptions about the ritual. Even though the value of this theoretical background is unquestionable, Pelevin's prose also demands an additional rethinking of the theories in order to better understand the world created in his works. It contradicts the widely spread notion that ritual is meant to transform 
the participants. It may or may not transform the participants - the outcome can be different. This failure of initiation reflects the state of post-Soviet people in general, consciously or unconsciously refusing the changes that took place during the break-up of the Soviet structure and hence refusing to move forward to the final stage, that is, reintegration into the new structure. By creating his own interpretation of rituals and inventing new forms, Pelevin redefines the sacred in contemporary society and proves the relativity and temporality of all sacred structures. His prose both confirms the value of the ritual theories and presents a challenge to them.

Pelevin's notion of escape itself can be understood as sacred: an overwhelming desire to escape the surrounding reality that is no longer satisfactory or to connect with the world that is lost. Hence psychedelics can be the most illustrative metaphor and the most visible means of that escape, which can present itself in other forms such as art, ideology, or religion. It is not only an escape from (liminal) realities, but also an escape 'to': a trip in search for the new sacred (experiences). At times, escape 'to' can merely be striving to return to the 'old sacred' - nostalgia for the Soviet past. This nostalgic yearning for the lost sacred, the lost structured life and inability to regain it once again reflects the confused state of the postSoviet people. Also, escape 'to' can mean striving for freedom, which in Pelevin's works presents itself as a sacred category, both as the destination and the journey.

As if confirming the ambiguity of the notion of the sacred, both a positive and a negative category, freedom is also a very ambiguous category - the desired state, the blessing and the curse. It illustrates Pelevin's ambiguity: in-between the Western notion of freedom as a positive category, the Eastern notion of the absolute freedom as liberation, and the Russian notion of freedom as a sinful category, as only slavishness can be sacred. Hence it illustrates the hypothesis of the first chapter: that the sacred in the contemporary milieu is a relative and temporary category.

Pelevin's works present the trajectories of the changing notions of the sacred. In his writings, the sacred can be traced as temporary, dynamic and fragmentary. However, this dynamics also changes over time. In other words, it is not chaotic - it has its own logic. The notions of the sacred in Pelevin's books eventually become less fragmentary and more definitive. Pelevin's dynamics of the sacred - the disillusionment with the Soviet structure and its false eternity; the early capitalism's monetary philosophy; the engagement with the exotic new spiritualities; the rejection of all belief systems in the search of the deeply personal and meaningful sacred - coincides with the phases in post-Soviet society. Pelevin captures the changing moods in society and accurately reflects them in his works, and his 
seeking for the new forms of the sacred is dynamic and continuously evolving. And because Pelevin with his fiction in many ways transcends and includes the existing Russian literary trajectories, the sacred, emerging in his works, is reflected in a more complex and profound way. This once again proves the productivity of the choice of Pelevin as representative of the post-Soviet period.

The changing forms of the escape/journey to freedom in his books, as well as the evolvement of the notion of emptiness, illustrate the writer's search for new expressions, continuous personal transformation, and his own journey. The framework of this research helped to track these changes - from the simplified version of the so-called 'pop-Buddhism' in Buddha's Little Finger to the multi-layered concepts in the novel $T$, where emptiness and freedom is discussed in the postmodernist context of the role of author/creator/reader/protagonist. The notion of 'freedom from' in the first Pelevin's books (freedom from the Soviet state in Omon Ra, The Yellow Arrow, freedom from everything created by the mind in Buddha's Little Finger, The Sacred Book of the Werewolf) in his later works is changed into the 'freedom to' - to actively create personal meanings and a personal sacred, or to state that there is no (absolute) sacred at all $(T)$.

In this sense, and again, contrary to critics, stating that Pelevin is repeating himself, the writer stands out as actively transforming and deepening his understanding and thus presenting himself and his creative work as an infinite possibility.

\section{Future Research Directions}

Due to the scope of this research, many important questions were not covered here and therefore present future challenges. These future research trajectories include, but are not limited to, first, Pelevin's refashioning and deconstructing of the myths, also creating new myths (such as refashioning the myth of the Soviet cosmic power in Omon Ra, the myth of the Red Army hero Vasily Chapayev in Buddha's Little Finger, the interpretations of the biblical and mythological themes - the Tower of Babel etc). I believe the relation of the sacred and myth in his works presents an opportunity to further deepen the discussion on these core concepts.

Secondly, as this research focused mostly on the so-called 'personal' sacred and personal search for the sacred, the political side (and political myths) remained almost undiscussed. The dialectic of the sacred and the power would be a promising topic for a 
future research, as Pelevin can be considered as an explicitly political writer. I intend to return to these topics in my future research.

Thirdly, as mentioned, a complex and ambiguous Buddhist context in Pelevin's prose requires a separate study. His relations with the Orthodox Christian tradition also require an additional rethinking, as well as other inter-textual layers of his prose.

Lastly, this research paves the way for the future research of the (reinvented) sacred in contemporary prose. It also opens up the possibility for further comparative studies. 


\section{Bibliography}

\section{Primary Sources}

Pelevin, Viktor. Omon Ra. Zheltaia strela. Moskva: Vagryus, 2004.

Pelevin, Viktor. Empire V. Moskva: Eksto, 2006.

Pelevin, Viktor. Generation 'P.' Moskva: Eksto, 2006.

Pelevin, Viktor. Sviashchennaja kniga oborotnia. Moskva: Eksto, 2008.

Pelevin, Viktor. Chapaev i pustota. Moskva: Eksto, 2008.

Pelevin, Viktor. Chisla. Moskva: Eksto, 2009.

Pelevin, Viktor. T. Moskva: Eksto, 2009.

Pelevin, Viktor. Ananasovaya voda dlya prekrasnoy damy. Moskva: Eksto, 2011.

Pelevin, Victor. S.N.U.F.F. Moskva: Eksto, 2012.

Pelevin, Victor. The Life of Insects. Translated by Andrew Bromfield. New York: Farrar, Straus and Giroux, 1998.

Pelevin, Victor. Buddha's Little Finger. Translated by Andrew Bromfield. New York: Viking, 2000.

Pelevin, Victor. Homo Zapiens. Translated by Andrew Bromfield. New York: Viking, 2002.

Pelevin, Victor. The Sacred Book of the Werewolf. Translated by Andrew Bromfield. New York: Penguin Books, 2008.

\section{Secondary Sources}

Allen, Douglas. Myth and Religion in Mircea Eliade. New York: Routledge, 2002.

Allen, Douglas. "Mircea Eliade's View of the Study of Religion as the Basis for Cultural and Spiritual Renewal." In Changing Religious Worlds: The Meaning and End of Mircea Eliade, ed. Bryan S. Rennie, 207-235. Albany: State University of New York Press, 2001.

Almond, Philip C. "Rudolf Otto: Life and Work." Journal of Religious History 12, no. 3 (1983): 305-21. 
Anttonen, Veikko. "Sacred." In Guide to the Study of Religion, ed. Willi Braun and Russell T. McCutcheon, 271-82. London; New York: Cassell, 2000.

Anttonen, Veikko. "What Is It That We Call 'Religion'? Analyzing the Epistemological Status of the Sacred as a Scholarly Category in Comparative Religion." Method \& Theory in the Study of Religion 12, no. 1-2 (2000): 195-206.

Bandera, Cesareo. The Sacred Game: The Role of the Sacred in the Genesis of Modern Literary Fiction. University Park, Pa: Pennsylvania State University Press, 2004.

Basinskii, Pavel. "The Pelevin Syndrome." Russian Studies in Literature 37, no. 3 (2001): 89-96.

Barker, Adele Marie. "The Culture Factory: Theorizing the Popular in the Old and New Russia." In Consuming Russia: Popular Culture, Sex, and Society since Gorbachev, ed. Adele Marie Barker, 12-48. Durham: Duke University Press, 1999.

Beck, Jerome, and Marsha Rosenbaum. Pursuit of Ecstasy: The MDMA Experience. New York: State University of New York Press, 1994.

Bell, Catherine M. "Ritual." In The Blackwell Companion to the Study of Religion, ed. Robert Alan Segal, 397-412. Malden, MA: Blackwell Pub., 2006.

Bell, Catherine M. Ritual: Perspectives and Dimensions. New York: Oxford University Press, 1997.

Bell, Catherine M. Ritual Theory, Ritual Practice. New York: Oxford University Press, 1992.

Bellah, Robert N., and Phillip E. Hammond. Varieties of Civil Religion. San Francisco: Harper\&Row, 1980.

Bennett, Clinton. In Search of the Sacred: Anthropology and the Study of Religions. London; New York: Cassell, 1996.

Berman, Harold J. Faith and Order: The Reconciliation of Law and Religion. Grand Rapids, Mich.: W.B. Eerdmans Pub. Co., 2000.

Borenstein, Eliot. "Suspending Disbelief: Cults and Postmodernism in Contemporary Russia." In Consuming Russia: Popular Culture, Sex, and Society since Gorbachev, ed. Adele Barker, 437-462. Durham: Duke University Press, 1999.

Boym, Svetlana. Common Places: Mythologies of Everyday Life in Russia. Cambridge, Mass.: Harvard University Press, 1994.

Boym, Svetlana. "From the Russian Soul to Post-Communist Nostalgia." Representations 49 (1995): 133-166.

Boym, Svetlana. The Future of Nostalgia. New York: Basic Books, 2001. 
Brintlinger, Angela. "The Hero in the Madhouse: The Post-Soviet Novel Confronts the Soviet Past." Slavic Review 63, no. 1 (2004): 43-65.

Buckler, Julie A. "What Comes After 'Post-Soviet' in Russian Studies?” PMLA 124, no. 1 (2009): 251-263.

Burkert, Walter, Rene Girard, Jonathan Z. Smith, and Robert Hamerton-Kelly. Violent Origins. Stanford, Calif.: Stanford University Press, 1987.

Brown, Willi. "Religion." In Guide to the Study of Religion, ed. Willi Braun and Russell T. McCutcheon, 3-20. London; New York: Cassell, 2000.

Callois, Roger. Man and the Sacred. Translated by Meyer Barash. Urbana: University of Illinois Press, 2001.

Clark, Katerina. The Soviet Novel: History as Ritual. Bloomington: Indiana University Press, 2000.

Coleman, Elizabeth Burns, and Kevin White. "Stretching the Sacred." In Negotiating the Sacred: Blasphemy and Sacrilege in a Multicultural Society, ed. Elizabeth Burns Coleman and Kevin White, 65-77. Canberra: Anu E Press, 2006.

Corless, Roger. "Building on Eliade's Magnificent Failure." In Changing Religious Worlds: The Meaning and End of Mircea Eliade, ed. Bryan S. Rennie, 3-9. Albany: State University of New York Press, 2001.

Cortright, Brant. Integral Psychology: Yoga, Growth, and Opening the Heart. Albany: State University of New York Press, 2007.

Coupland, Douglas. Generation X: Tales for an Accelerated Culture. London: Abacus, 1992.

Coupland, Douglas. JPod. New York: Bloomsbury, 2006.

Crowder, Colin. "Rudolf Otto's The Idea of the Holy Revisited." In Holiness Past and Present, ed. Stephen C. Barton, 22-47. London; New York: T \& T Clark, 2003.

Dadosky, John Daniel. The Structure of Religious Knowing: Encountering the Sacred in Eliade and Lonergan. Albany: State University of New York Press, 2004.

Dalton-Brown, Sally. "Ludic Nonchalance or Ludicrous Despair? Victor Pelevin and Russian Postmodernist Prose." The Slavonic and East European Review 75, no. 2 (1997): 216233.

Dalton-Brown, Sally. "The Dialectics of Emptiness: Douglas Coupland's and Viktor Pelevin's Tales of Generation X and P." Forum for Modern Language Studies 42, no. 3 (2006): 239-248.

Deflem, Mathieu. "Ritual, Anti-Structure, and Religion: A Discussion of Victor Turner's Processual Symbolic Analysis." Journal for the Scientific Study of Religion 30, no. 1 (1991): 1-25. 
Demerath, N. J., III. "The Varieties of Sacred Experience: Finding the Sacred in a Secular Grove." Journal for the Scientific Study of Religion 39, no. 1 (2000): 1-11.

Dobkin de Rios, Marlene. The Wilderness of Mind: Sacred Plants in Cross-Cultural Perspective. Beverly Hills: Sage Publications, 1976.

Douglas, Mary. Purity and Danger: An Analysis of Concepts of Pollution and Taboo. London: Routledge \& Kegan Paul, 1969.

Dubuisson, Daniel. Twentieth Century Mythologies. London: Equinox, 2006.

Durkheim, Emile. The Elementary Forms of Religious Life. Translated by Carol Cosman. New York: Oxford University Press, 2001.

Eliade, Mircea, "The Structure and Morphology of the Sacred." In Mircea Eliade: A Critical Reader, ed. Bryan S. Rennie, 41-56. London; Oakville, CT: Equinox Pub, 2006.

Eliade, Mircea. "Introduction to the Sacred and the Profane." In Mircea Eliade: A Critical Reader, ed. Bryan S. Rennie, 17-22. London; Oakville, CT: Equinox Pub, 2006.

Eliade, Mircea. "The Sacred in the Secular World." In Mircea Eliade: A Critical Reader, ed. Bryan S. Rennie, 57-67. London; Oakville, CT: Equinox Pub, 2006.

Eliade, Mircea. The Sacred and the Profane; the Nature of Religion. Translated by Willard R. Trask. New York: Harcourt, 1959.

Eliade, Mircea. The Myth of the Eternal Return. Translated by Willard R. Trask. London: Routledge, 1982.

Engelstein, Laura. "Paradigms, Pathologies and Other Clues to Russian Spiritual Culture: Some Post-Soviet Thoughts." Slavic Review 57, no. 4 (1998): 864-877.

Epstein, Mikhail. “'Post-' and Beyond.” The Slavic and East European Journal 39, no. 3 (1995): 357-366.

Epstein, Mikhail. "Post-Atheism: From Apophatic Theology to 'Minimal Religion'." In Russian Postmodernism: New Perspectives on Post-Soviet Culture, ed. Mikhail Epstein, Alexander Genis, and Slobodanka Vladiv-Glover, 345-393. New York: Berghahn Books, 1999.

Epstein, Mikhail. "Minimal Religion." In Russian Postmodernism: New Perspectives on Post-Soviet Culture, ed. Mikhail Epstein, Alexander Genis, and Slobodanka VladivGlover, 163-171. New York: Berghahn Books, 1999.

Fadiman, James. "Transpersonal Transitions: The Higher Reaches of Psyche and Psychology." In Higher Wisdom: Eminent Elders Explore the Continuing Impact of Psychedelics, ed. Roger Walsh and Charles S. Grob, 21-47. New York: State University of New York Press, 2005. 
Fontana, David. Psychology, Religion and Spirituality. Malden: BPS Blackwell, 2003.

Fujiwara, Satoko. "The Emergence of the Sacred: A Historical and Theoretical Critique of a Key Concept in the Study of Religion.” PhD diss., University of Chicago, 2001.

Genis, Alexander. "Perestroika as a Shift in Literary Paradigm." In Russian Postmodernism: New Perspectives on Post-Soviet Culture, ed. Mikhail Epstein, Alexander Genis, and Slobodanka Vladiv-Glover, 87-102. New York: Berghahn Books, 1999.

Genis, Alexander. "Borders and Metamorphoses: Viktor Pelevin in the Context of PostSoviet Literature." In Russian Postmodernism: New Perspectives on Post-Soviet Culture, ed. Mikhail Epstein, Alexander Genis, and Slobodanka Vladiv-Glover, 212224. New York: Berghahn Books, 1999.

Gennep, Arnold van. The Rites of Passage. London: Routledge \& Kegan Paul, 1960.

Girard, René. Violence and the Sacred. Translated by Patrick Gregory. Baltimore: Johns Hopkins University Press, 1977.

Gooch, Todd A. The Numinous and Modernity: An Interpretation of Rudolf Otto's Philosophy of Religion. New York: W. de Gruyter, 2000.

Goodchild, Philip. Theology of Money. Durham: Duke University Press, 2009.

Grimes, Ronald L. "Ritual." In Guide to the Study of Religion, ed. Willi Braun and Russell T. McCutcheon, 259-70. London; New York: Cassell, 2000.

Grimes, Ronald L. "Sources for the Study of Ritual." Religious Studies Review 10, no. 2 (1984): 134-45.

Grimes, Ronald L. "Victor Turner's Definition, Theory, and Sense of Ritual." In Victor Turner and the Construction of Cultural Criticism: Between Literature and Anthropology, ed. Kathleen M. Ashley, 141-147. Indiana: Indiana University Press, 1990.

Grof, Stanislav. The Adventure of Self-Discovery. Albany: State University of New York Press, 1988.

Grof, Stanislav. "The Potential of Entheogens as Catalysts of Spiritual Development." In Psychoactive Sacramentals: Essays on Entheogens and Religion, ed. Thomas B. Roberts, 27-46. San Francisco: Council on Spiritual Practices, 2001.

Herlihy, Patricia. "Revenue and Revelry on Tap: The Russian Tavern." In Alcohol: A Social and Cultural History, ed. Mack P. Holt, 185-202. Oxford, New York: Berg, 2006.

Hervieu-Léger, Danièle. Religion as a Chain of Memory. Translated by Simon Lee. Cambridge: Polity Press in association with Blackwell, 2000. 
Hofmann, Albert. "LSD as a Spiritual Aid." In Psychoactive Sacramentals: Essays on Entheogens and Religion, ed. Thomas B. Roberts, 121-123. San Francisco: Council on Spiritual Practices, 2001.

Holy Bible. New Revised Standard Version. New York: American Bible Society, 1989.

Hruby, Paula Jo. "Unitive Consciousness and Pahnke's Good Friday Experiment." In Psychoactive Sacramentals: Essays on Entheogens and Religion, ed. Thomas B. Roberts, 58-68. San Francisco: Council on Spiritual Practices, 2001.

Hubert, Henri, and Marcel Mauss. Sacrifice; Its Nature and Function. London: Cohen \& West, 1964.

Hume, Lynne. "Liminal Beings and the Undead: Vampires in the $21^{\text {st }}$ Century." In Popular Spiritualities: The Politics of Contemporary Enchantment, ed. Lynne Hume and Kathleen McPhillips, 3-17. Aldershot: Ashgate Publishing, 2006.

Idinopulos, Thomas A. “The Strengths and Weaknesses of Durkheim's Methodology for the Study and Teaching of Religion." In Reappraising Durkheim for the Study and Teaching of Religion Today, ed. Thomas A. Idinopulos and Brian C. Wilson, 1-14. Leiden; Boston: Brill, 2002.

Ivanova, Natal'ia. "Afterward: Post-Soviet Literature in Search of a New Identity." Russian Social Science Review 39, no. 4 (1998): 75-96.

Ivashkiv, Roman. "Postmodern Approaches to Representation of Reality in Ukrainian and Russian Literatures: The Prose of Yuri Andrukhovych and Viktor Pelevin." Journal of Ukrainian Studies 32, no. 1 (2007): 37-61.

James, William. The Varieties of Religious Experience: A Study in Human Nature, Being the Clifford Lectures on Natural Religion Delivered at Edinburgh in 1901-1902. New York: Longmans, Green, and co., 1902.

Khagi, Sofya. "From Homo Sovieticus to Homo Zapiens: Viktor Pelevin's Consumer Dystopia." The Russian Review 67, no. 4 (2008): 559-579.

Kovács, András Bálint. "Sartre, the Philosophy of Nothingness, and the Modern Melodrama." The Journal of Aesthetics and Art Criticism 64.1 (2006): 135-145.

La Fontaine, Jean Sybil. Initiation. Manchester: Manchester University Press, 1986.

Leeuw, Gerardus van der. "Religion in Essence and Manifestation." In Theories of Religion: A Reader, ed. Seth Daniel Kunin and Jonathan Miles-Watson, 134-143. New Jersey: Rutgers University Press, 2006.

Lefebure, Leo D. "Victims, Violence and the Sacred: The Thought of René Girard." Christian Century 113, no. 36 (1996): 1226-1229.

Lipovetsky, Mark. "New Russians as a Cultural Myth.” Russian Review 62, no. 1 (2003): 5471. 
Lipovetsky, Mark. "Russian Literary Postmodernism in the 1990s." The Slavonic and East European Review 79, no. 1 (2001): 31-50.

Lipovetsky, M. N., and Eliot Borenstein. Russian Postmodernist Fiction: Dialogue with Chaos. Armonk, NY: M. E. Sharpe, 1999.

Livers, Keith. "Bugs in the Body Politic: The Search for Self in Viktor Pelevin's The Life of Insects." Slavic and East European Journal 46, no. 1 (2002): 1-28.

Livers, Keith. "The Tower or the Labyrinth: Conspiracy, Occult, and Empire-Nostalgia in the Work of Viktor Pelevin and Aleksandr Prokhanov." The Russian Review 69, no. 3 (2010): 477-503.

Ljuggren, Anna. "Closing the Circle: On the Poetics of Contemporary Russian Prose." Russian Literature 65, no. 4 (2009): 451-66.

Lynch, Gordon. "What is this 'Religion' in the Study of Religion and Popular Culture?" In Between Sacred and Profane: Researching Religion and Popular Culture, ed. Gordon Lynch, 125-143. London; New York: I. B. Tauris, 2007.

Lynch, Gordon. The New Spirituality: An Introduction to Progressive Belief in the Twentyfirst Century. New York: I. B. Tauris, 2007.

Madden, Kathryn. "Ritual, Drama, and the Unconscious in the Eucharist: Contributions of Victor Turner to Depth Psychology and Religion." Union Seminary Quarterly Review 53, no. 1-2 (1999): 111-24.

Mandelbaum, Michael. "Coup de Grace: The End of the Soviet Union." Foreign Affairs 71, no. 1 (1991/1992): 164-183.

Mahdi, Louise Carus. "Introduction." In Betwixt and Between: Patterns of Masculine and Feminine Initiation, ed. Louise Carus Mahdi, Steven Foster and Meredith Little, ixxv. La Salle, Ill.: Open Court, 1987.

Marsh, Rosalind. Literature, History and Identity in Post-Soviet Russia, 1991-2006. Bern: Peter Lang, 2007.

McAvan, Em. "The Postmodern Sacred: Popular Culture Spirituality in the Genres of Science Fiction, Fantasy and Fantastic Horror.” PhD diss., Murdoch University, 2007.

McCutcheon, Russell T. Studying Religion: An Introduction. London; Oakville, CT: Equinox Pub., 2007.

McCutcheon, Russell T. Manufacturing Religion: The Discourse on Sui Generis Religion and the Politics of Nostalgia. New York: Oxford University Press, 1997.

McCutcheon, Russel. "Methods, Theories and the Terrors of History." In Changing Religious Worlds: The Meaning and End of Mircea Eliade, ed. Bryan S. Rennie, 11-25. Albany: State University of New York Press, 2001. 
Miller, Watts W. "Secularism and the Sacred: Is There Really Something Called 'Secular Religion?"' In Reappraising Durkheim for the Study and Teaching of Religion Today, ed. Thomas A. Idinopulos and Brian C. Wilson, 27-45. Leiden; Boston: Brill, 2002.

Miller, W. Watts. "Durkheim, Kant, the Immortal Soul and God." In On Durkheim's Elementary Forms of Religious Life, ed. N. J. Allen, W. S. F. Pickering, and William Watts-Miller, 66-78. London; New York: Routledge, 1998.

Milton, Kay. Loving Nature: Towards an Ecology of Emotion. London: Routledge, 2002.

Miner, Horace. "Body Ritual among the Nacirema." American Anthropologist 58, no. 3 (1956): 503-507.

Moore, Sally Falk, and Barbara G. Myerhoff. Secular Ritual. Assen: Van Gorcum, 1977.

Mørch, Audun J. "Reality as Myth: Pelevin's Čapaev i Pustota.” Scando-Slavica 51, no. 1 (2005): 61-79.

Mozur, Joseph. "Viktor Pelevin: Post-Sovism, Buddhism, \& Pulp Fiction." World Literature Today 76, no. 2 (2002): 58-67.

Neidhart, Ch. Russia's Carnival: The Smells, Sights, and Sounds of Transition. Lanham, MD: Rowman \& Littlefield, 2002.

Newland, Guy. Introduction to Emptiness. Ithaca: Snow Lion Publications, 2009.

Nishitani, Keiji. Religion and Nothingness. Translated by J. Van Bragt. Berkeley: University of California Press, 1982.

Noordenbos, Boris. "Breaking into a New Era? A Cultural-Semiotic Reading of Viktor Pelevin.” Russian Literature 64, no. 1 (2008): 85-107.

Olaveson, Tim. "Collective Effervescence and Communitas: Processual Models of Ritual and Society in Emile Durkheim and Victor Turner." Dialectual Anthropology 26 (2001): 89-124.

Otto, Rudolf. The Idea of the Holy: An Inquiry into the Non-Rational Factor in the Idea of the Divine and Its Relation to the Rational. New York: Oxford University Press, 1950.

Otto, Rudolf. Religious Essays: A Supplement to 'The Idea of the Holy'. London: Oxford University Press, 1931.

Oushakine, Serguei. "In the State of Post-Soviet Aphasia: Symbolic Development in Contemporary Russia.” Europe-Asian Studies 52, no. 6 (2000): 991-1016.

Paden, William E. "The Creation of Human Behaviour: Reconciling Durkheim and the Study of Religion." In Reappraising Durkheim for the Study and Teaching of Religion 
Today, ed. Thomas A. Idinopulos and Brian C. Wilson, 15-27. Leiden; Boston: Brill, 2002.

Paden, William E. "Before 'The Sacred' Became Theological: Rereading the Durkheimian Legacy." In Mircea Eliade: A Critical Reader, ed. Bryan S. Rennie, 68-81. London; Oakville, CT: Equinox Pub, 2006.

Paden, William E. "The Concept of World Habitation: Eliadean Linkages with a New Comparativism." In Changing Religious Worlds: The Meaning and End of Mircea Eliade, ed. Bryan S. Rennie, 249-263. Albany: State University of New York Press, 2001.

Paden, William E. 'Sacrality as Integrity: 'Sacred Order' as a Model for Describing Religious Worlds." In The Sacred and Its Scholars: Comparative Methodologies for the Study of Primary Religious Data, ed. by Thomas A. Idinopulos and Edward A. Yonan, 3-18. Leiden; New York: E.J. Brill, 1996.

Partridge, Christopher. The Re-Enchantment of the West. Volume 1. London: T\&T Clark, 2004.

Partridge, Christopher. The Re-Enchantment of the West. Volume 2, Studies in Sacralization and Occulture. London: T\&T Clark, 2006.

Parts, Lyudmila. "Degradation of the Word or the Adventures of an Intelligent in Viktor Pelevin's Generation P." Canadian Slavonic Papers 46, no. 3/4 (2004): 435-449.

Piatt, Christian, and Amy Piatt. MySpace to Sacred Space: God for a New Generation. St. Louis, Mo.: Chalice Press, 2007.

Plato. The Phaedrus, Lysis, and Protagoras. Translated by J. Wright. London: Parker, 1848.

Poland, Lynn. "The Idea of the Holy and the History of the Sublime." Journal of Religion 72, no. 2 (1992): 175-97.

Presti, David, and Jerome Beck. "Strychnine and Other Enduring Myths: Expert and User Folklore Surrounding LSD." In Psychoactive Sacramentals: Essays on Entheogens and Religion, ed. Thomas B. Roberts, 125-137. San Francisco: Council on Spiritual Practices, 2001.

Prothero, Stephen. God Is Not One: The Eight Rival Religions That Run the World and Why Their Differences Matter. Melbourne: Black Inc., 2010.

Proust, Marcel. Swann's Way. Translated by C.K. Scott Moncrieff. London: Chatto \& Windus, 1957.

Rancour-Laferriere, Daniel. The Slave Soul of Russia: Moral Masochism and the Cult of Suffering. New York: New York University Press, 1995.

Raphael, Melissa. Rudolf Otto and the Concept of Holiness. Oxford: Clarendon Press, 1997. 
Read, Christopher. The Making and Breaking of the Soviet System. Basingtoke: Palgrave, 2001.

Reynolds, S. Generation Ecstasy: Into the World of Techno and Rave Culture. New York: Routledge, 1999.

Richards, Susan. Lost and Found in Russia: Lives in a Post-Soviet Landscape. New York: Other Press, 2010.

Robbins, Jill. "Sacrifice." In Critical Terms for Religious Studies, edited by Mark C. Taylor, 285-297. Chicago: University of Chicago Press, 1998.

Rogerson, John. "What is Holiness?" In Holiness Past and Present, ed. Stephen C. Barton, 322. London; New York: T \& T Clark, 2003.

Sakwa, Richard. Russian Politics and Society. London: Routledge, 2002.

Scherr, Barry P. "After Perestroika: Era of Rasstroika." South Central Review 12, no. 3/4 (1995): 153-167.

Segal, Robert. "Reductionism in the Study of Religion." In Theories of Religion: A Reader, ed. Seth Daniel Kunin and Jonathan Miles-Watson, 143-154. New Jersey: Rutgers University Press, 2006.

Segal, Robert A. “Victor Turner’s Theory of Ritual.” Zygon 18, no. 3 (1983): 327-35.

Shamanism: An Encyclopaedia of World Beliefs, Practices, and Culture, vol. II, ed. Mariko Namba Walter and Eva Jane Neumann Fridman. Santa Barbara, Calif.: ABC-CLIO, 2004.

Shipton, Parker. "Blood, Fire, and Word: Luo, Christian, and Luo-Christian Sacrifice." In Ritual, ed. Pamela J. Stewart and Andrew Strathern, 477-500. Farnham, Surrey, England; Burlington, VT: Ashgate Pub. Co., 2010.

Shneidman, N.N. Russian Literature, 1995-2002: On the Threshold of the New Millenium. Toronto: University of Toronto Press, 2004.

Shterin, Marat. "New Religions in the New Russia." In New Religious Movements in the Twenty-First Century: Legal, Political, and Social Challenges in Global Perspective, ed. Phillip Charles Lucas and Thomas Robbins, 99-116. New York: Routledge, 2004.

Smart, Ninian. "Review of Mircea Eliade (ed.), The Encyclopedia of Religion." Religious Studies Review 14, no. 3 (1988): 193-199.

Smith, Huston. Cleansing the Doors of Perception: The Religious Significance of Entheogenic Plants and Chemicals. New York: Jeremy P. Tarcher/Putnam, 2000.

Smith, Jonathan Z. Imagining Religion: From Babylon to Jonestown. Chicago: University of Chicago Press, 1982. 
Söderblom, Nathan. Living God: Basal Forms of Personal Religion. London: Oxford University Press, 1939.

Spohn, Willfried. “Transformation Process, Modernization Patterns, and Collective Identities: Democratization, Nationalism, and Religion in Postcommunist Germany, Poland and Russia." In Postcommunist Transformation and the Social Sciences: CrossDisciplinary Approaches, ed. Frank Bonker, Klaus Muller, and Andreas Pickel, 199218. Lanham, MD: Rowman \& Littlefield, 2002.

Steiger, Krystyna A. "Satire, Parody, and Nostalgia on the Threshold: Viktor Pelevin's Chapaev i Pustota in the Context of its Times." PhD diss., McGill University, 2004.

Steinberg, Mark D., and Catherine Wilson. "Introduction: Reclaiming the Sacred after Communism." In Religion, Morality, and Community in Post-Soviet Societies, ed. Mark D. Steinberg and Catherine Wilson, 1-20. Washington, DC: Woodrow Wilson Center Press co-published by Indiana University Press, 2008.

Steindl-Rast, David. "Psychoactive Sacramental: Foreword." In Psychoactive Sacramentals: Essays on Entheogens and Religion, ed. Thomas B. Roberts, xi-xiv. San Francisco: Council on Spiritual Practices, 2001.

Stolaroff, Myron. "A Protocol for a Sacramental Service." In Psychoactive Sacramentals: Essays on Entheogens and Religion, ed. Thomas B. Roberts, 155-162. San Francisco: Council on Spiritual Practices, 2001.

Streetman, Robert F. "Some Later Thoughts of Otto on the Holy." Journal of the American Academy of Religion 48, no. 3 (1980): 365-84.

Swanson, Paul L. "Absolute Nothingness and Emptiness in Nishitani Keiji: An Essay from the Perspective of Classical Buddhist Thought." Eastern Buddhist 29, no. 1 (1996): 99-108.

Szakolczai, Arpad. Reflexive Historical Sociology. London: Routledge, 2000.

Szerszynski, Bronislaw. Nature, Technology, and the Sacred. Malden: Blackwell, 2005.

Tacey, David J. Edge of the Sacred: Transformation in Australia. North Blackburn, Vic., Australia: HarperCollinsPublishers, 1995.

Takahashi, Melanie. "Spirituality through the Science of Sound: The DJ as Technoshaman in Rave Culture." In Call Me the Seeker: Listening to Religion in Popular Music, ed. Michael J. Gilmour, 239-265. New York; London: Continuum, 2005.

Thomas, Terence. "“The Sacred' as a Viable Concept in the Contemporary Study of Religions." In Religion: Empirical Studies, ed. Steven Sutcliffe, 47-67. Aldershot: Ashgate, 2004.

Thomassen, Bjorn. "Anthropology and Its Many Modernities: When Concepts Matter." Journal of the Royal Anthropological Institute 18 (2012): 160-178. 
Tobin, Daniel. Passage to the Center: Imagination and the Sacred in the Poetry of Seamus Heaney. Kentucky: University Press of Kentucky, 1999.

Todorova, Maria. "From Utopia to Propaganda and Back." In Post-Communist Nostalgia, ed. Maria Todorova and Zsuzsa Gille, 1-16. New York: Berghahn Books, 2010.

Tramacchi, Des. "Entheogens, Elves and Other Entities: Encountering the Spirits of Shamanic Plants and Substances." In Popular Spiritualities: The Politics of Contemporary Enchantment, ed. Lynne Hume and Kathleen McPhillips, 91-104. Aldershot, England; Burlington, VT: Ashgate, 2006.

Tuh, Boris. Pervaja desiatka sovremennoj russkoj literatury. Oniks 21 vek: Moskva, 2002.

Turner, Victor. The Anthropology of Performance. New York: PAJ Publications, 1986.

Turner, Victor W. The Ritual Process: Structure and Anti-Structure. London: Routledge \& Kegan Paul, 1970.

Turner, Victor W. The Forest of Symbols: Aspects of Ndembu Ritual. New York: Cornell University Press, 1967.

Turner, Victor. Dramas, Fields, and Metaphors; Symbolic Action in Human Society, Symbol, Myth, and Ritual. Ithaca [N.Y.]: Cornell University Press, 1974.

Vladiv-Glover, Slobodanka. "From Bread Dolls to Prostitutes: A Cultural Diagnosis of PostSoviet Russia." Georgetown Journal of International Affairs 8, no. 1 (2007): 87-94.

Wachtel, Andrew Baruch. Remaining Relevant After Communism: The Role of the Writer in Eastern Europe. Chicago: University of Chicago Press, 2006.

Walsh, Roger, and Charles S. Grob. "Psychedelic and the Western World: A Fateful Marriage." In Higher Wisdom: Eminent Elders Explore the Continuing Impact of Psychedelics, ed. Roger Walsh and Charles S. Grob, 1-6. New York: State University of New York Press, 2005.

Wasson, Gordon R. Soma, Divine Mushroom of Immortality. New York: Harcourt Brace Jovanovich, 1968.

Wasson, R. G. and V. P. Russia, Mushrooms and History. 2 vols. New York: Pantheon, 1957.

Werbner, Richard P. Ritual Passage, Sacred Journey: The Process and Organization of Religious Movement. Washington: Smithsonian Institution Press; Manchester, UK: Manchester University Press, 1989.

Young, Mike. "If I Could Change Your Mind." In Psychoactive Sacramentals: Essays on Entheogens and Religion, ed. Thomas B. Roberts, 1-8. San Francisco: Council on Spiritual Practices, 2001.

Yurchak, A. Everything Was Forever, Until it Was No More: The Last Soviet Generation. Princeton: Princeton University Press, 2006. 
Zigon, J. Making the New Post-Soviet Person: Moral Experience in Contemporary Moscow. Leiden: Brill, 2010.

\section{Websites}

Author unspecified. Interview with Viktor Pelevin. "I Never Was a Hero." http://www.guardian.co.uk/books/2000/apr/30/fiction (accessed August 11, 2012).

Author unspecified. "Interviu s pisatelem Viktorom Pelevinym." http://pelevinlive.ru/46 (accessed March 30, 2012).

Author unspecified. http://thisislike.com/victor-pelevin-writer/similar/ (accessed March 8, 2012).

Author unspecified. "Victor Pelevin: o sekse, mire i sebe." http://pelevinlive.ru/36 (accessed April 4, 2012).

Author unspecified.

http://lurkmore.to/\%D0\%9F\%D0\%B5\%D0\%BB\%D0\%B5\%D0\%B2\%D0\%B8\%D0 \%BD (accessed March 29, 2012).

Author unspecified. http://www.russianwriters.eu/en/pelevin/pelevintranslations.html (accessed June 30, 2011).

Author unspecified. "Virtualnaja konferencija s Viktorom Pelevinym." http://pelevin.nov.ru/interview/o-peirc/1.html (accessed July 25, 2011).

Armes, Keith. "Chekists in Cassocks: The Orthodox Church and the KGB." http://www.gwu.edu/ ieresgwu/assets/docs/demokratizatsiya\%20archive/0104_armes.pdf (accessed May 14, 2012).

Benedikter, Roland. "Postmodern Spirituality: A Dialogue in Five Parts." http://www.integralworld.net/benedikterla.html (accessed December 20, 2010).

Bey, Hakim. "The Temporary Autonomous Zone." http://hermetic.com/bey/taz3.html\#labelTAZ (accessed May 26, 2011).

Blomfield, Adrian. "Orthodox Church Unholy Alliance with Putin." http://www.telegraph.co.uk/news/worldnews/1579638/Orthodox-Church-unholyalliance-with-Putin.html (accessed May 14, 2012).

Borger, Julian. "How Born-Again George Became a Man on a Mission." http://www.guardian.co.uk/world/2005/oct/07/usa.georgebush (accessed February 21, 2012).

Budaragin, Michail. "Vremia T.” http://actualcomment.ru/daycomment/299/ (accessed June 30, 2011). 
Danilkin, Lev. “T-obraznyj tupik.” http://www.afisha.ru/book/1570/review/298339/ (accessed June 30, 2011).

Ganin, Martin. "Viktor Pelevin. T." http://www.openspace.ru/literature/events/details/13262/?expand=yes\#expand (accessed June 30, 2011).

Ganin, Martin. "Nazovu sebya Levitan." http://www.openspace.ru/literature/events/details/19226/?expand=yes\#expand (accessed November 19, 2011).

Genis, Alexander. "Fenomen Pelevina." http://pelevin.nov.ru/stati/o-gen1/1.html (accessed August 20, 2011).

Gurin, Stanislav. "Pelevin mezhdu budizmom i christianstvom." http://www.pelevin.info/pelevin_152_0.html (accessed July 14, 2011).

Evlogin, Kiril. "Prokliatije pisatelia P.” http://www.pelevin.info/pelevin_13_0.html (accessed July 10, 2011).

Kotik, Valia. "Iz niotkuda v nikuda.” http://www.pelevin.info/pelevin_11_0.html (accessed July 10, 2011).

Kropywiansky, Leo. Interview with Victor Pelevin.

http://bombsite.com/issues/79/articles/2481 (accessed December 20, 2010).

Narinskaya, Anna. "Vozvrashchenije glavnogo geroya." http://www.kommersant.ru/doc/1554035 (accessed November 19, 2011).

Nomad, Aleksei. “"T.', Viktor Pelevin.” http://www.newslab.ru/review/292551 (accessed June 30, 2011).

Novikov, Vladimir. "Literaturnyj peisazh posle nashestvija Pelevina." http://www.pelevin.info/pelevin_138_0.html?page=3 (accessed July 10, 2011).

Prigodich, Vasily. “Kto takoj Pelevin.” http://www.pelevin.info/pelevin_12_0.html (accessed July 10, 2011).

Proskuriakov, Dmitrij. "Naidi v sebe chitatelia, ili metafizika i ontologija teksta." http://www.pelevin.info/pelevin_148_0.html?page=1 (accessed June 30, 2011).

Rees, Jasper. "Prophet of the Absurd." http://www.independent.co.uk/arts-entertainment/artsprophet-of-the-absurd-1090104.html (accessed August 11, 2012).

Schwartz, Alexandra. "Sometimes a Small Redemption: On Ludmilla Petrushevskaya." http://www.thenation.com/article/sometimes-small-redemption-ludmillapetrushevskaya (accessed December 20, 2010). 
Toishin, Danila. "Interviu so zvezdoyi." http://pelevin.nov.ru/interview/o-toish/1.html (accessed December 20, 2010).

Vladimirskij, Vasilij. "Tolstoj i pustota.” http://www.mirf.ru/Reviews/review3953.htm (accessed June 30, 2011).

Voicechovskij B. "Interviu s pisatelem."

http://www.pelevin.info/pelevin_139_0.html?page=2 (accessed July 10, 2011.

Vorobjev, Vladimir. "Pravila zhizni Viktora Pelevina." http://esquire.ru/wil/pelevin (accessed August 8, 2012).

The social network. http://vk.com (accessed October 1, 2012).

\section{Filmography}

Generation P. Director Victor Ginzburg (2011). 